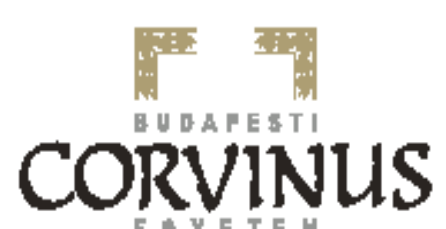

Általános és Kvantitatív Közgazdaságtan Doktori Iskola

\title{
PhD értekezés
}

\section{Fliszár Vilmos}

A budapesti bankközi forint hitelkamatláb

a londoni bankközi referencia-kamatláb árnyékában

Témavezető:

Solymosi Tamás PhD

egyetemi docens

Budapest, 2015 
Operációkutatás és Aktuáriustudományok Tanszék

\title{
PhD értekezés
}

\author{
Fliszár Vilmos
}

A budapesti bankközi forint hitelkamatláb

a londoni bankközi referencia-kamatláb árnyékában

Témavezető:

Solymosi Tamás PhD

egyetemi docens

(C) Fliszár Vilmos 
A tanulmányban megfogalmazott állítások a szerző álláspontját tükrözik, és nem feltétlen azonosak a Magyar Nemzeti Bank vagy a korábbi felügyeleti hatóság, a Pénzügyi Szervezetek Állami Felügyeletének álláspontjával. 


\section{Tartalomjegyzék}

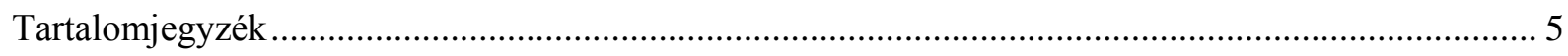

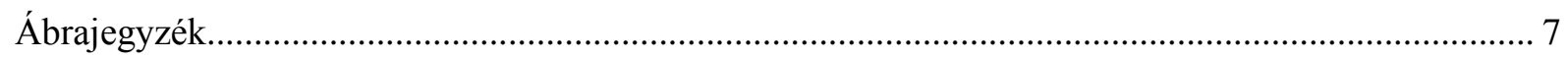

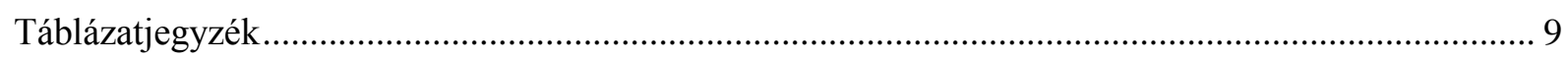

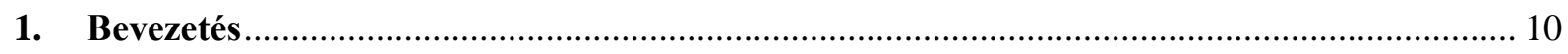

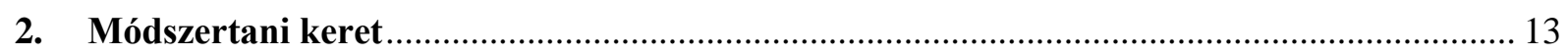

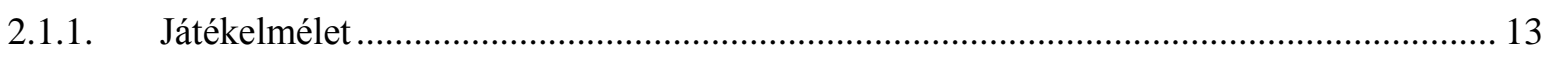

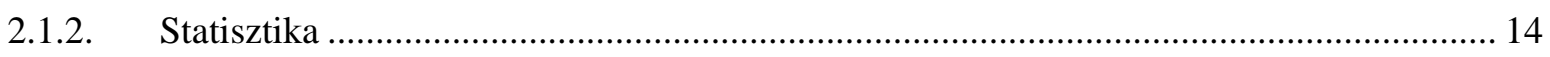

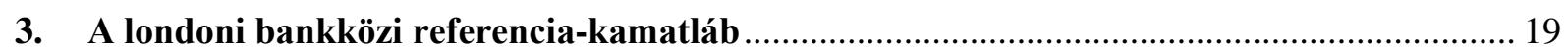

3.1. A londoni bankközi referencia-kamatláb definíciója............................................................. 19

3.1.1. A LIBOR-definícióból származó manipulálási ösztönzők játékelméleti megközelítésben21

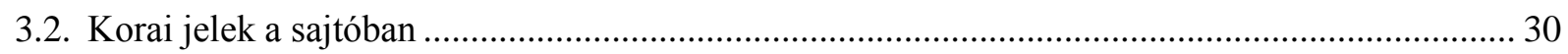

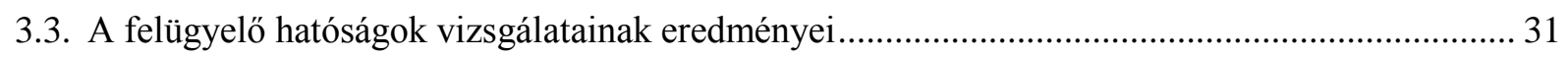

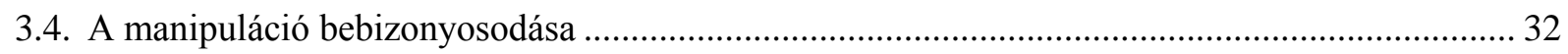

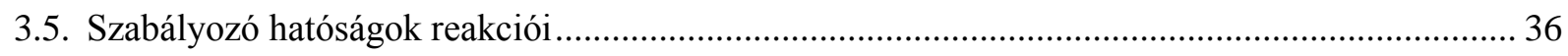

3.5.1. A referencia-kamatlábak Barclays általi manipulálásának vizsgálata ............................... 36

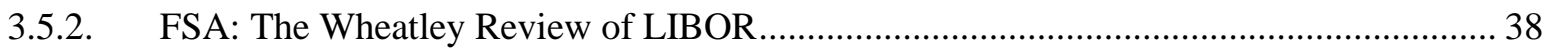

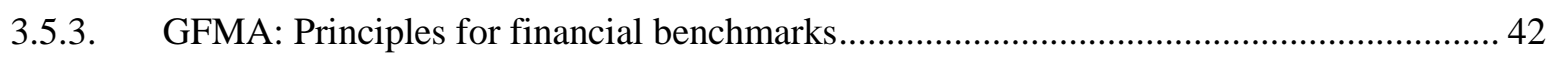

3.5.4. EBA-ESMA: strengthen Euribor and benchmark rate-setting processes ......................... 45

3.5.5. IOSCO: Consultation Report on Financial Benchmarks …................................................ 46

3.5.6. EBA - ESMA javaslat az Európai Bizottság számára a benchmarkokra vonatkozó

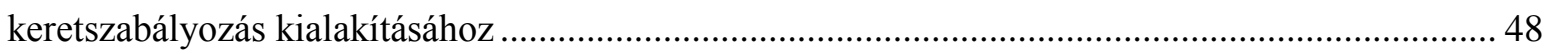

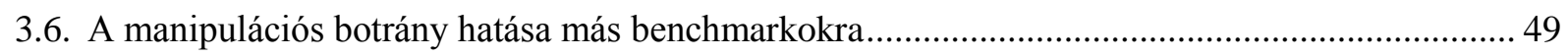

3.7. Magyarországi hatás - pénzügyi felügyeleti vizsgálat ................................................................ 49

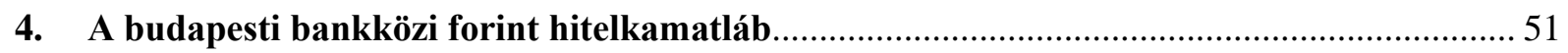

4.1. A Budapesti bankközi forint hitelkamatláb története …………................................................... 51

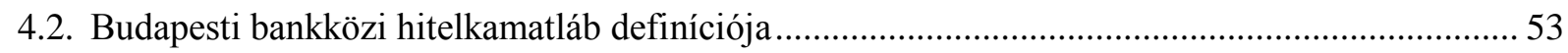

4.3. A BUBOR és a LIBOR közötti leglényegesebb különbségek ........................................................ 55

4.4. A budapesti bankközi hitelkamatláb beépülése a jogalkotási folyamatba ...................................... 56

4.4.1. A fair bank törvény hatása a forint referencia-kamatlábra ................................................ 58

5. A BUBOR-hoz köthető állományok és a BUBOR-jegyzések részletes statisztikai elemzése. 61

5.1. BUBOR-ral kapcsolatos elemzések a LIBOR-botrány előtt ......................................................... 61

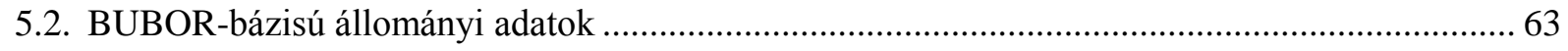

5.2.1. A BUBOR-hoz kapcsolódó hitel-betét állományok ……................................................ 63

5.2.2. Intézményi szintü, a BUBOR-hoz köthető derivatív pozíciók ......................................... 66 
5.2.3. A BUBOR-hoz köthető derivatív pozíciók és a jegyzések kapcsolata............................. 68

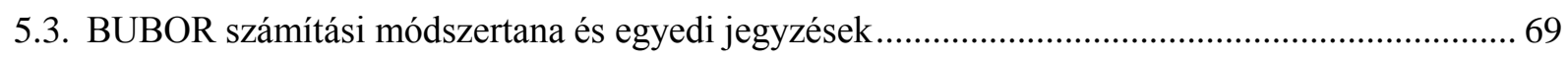

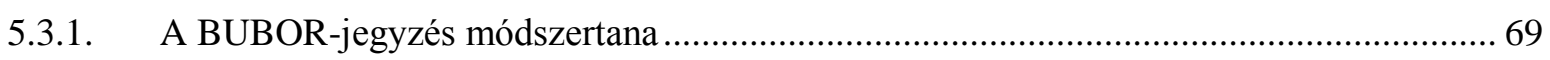

5.3.2. A BUBOR-jegyzések adatminősége 2012. június 30-ig ............................................... 73

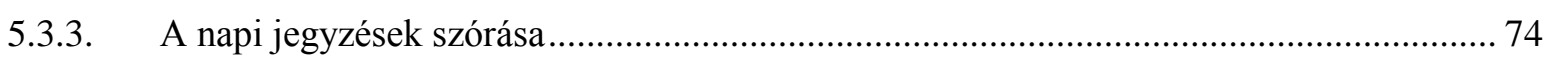

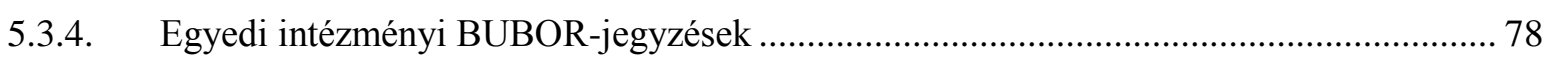

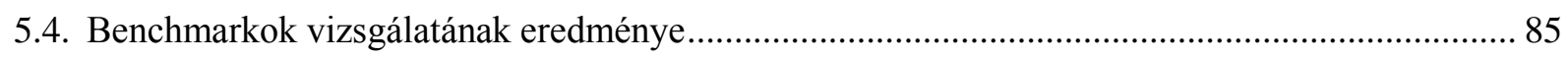

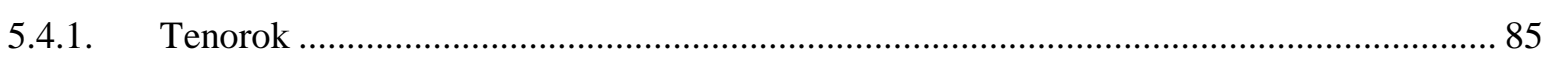

5.4.2. Alkalmazott benchmarkok (alapkamat, DKJ, swap és FRA) …..................................... 90

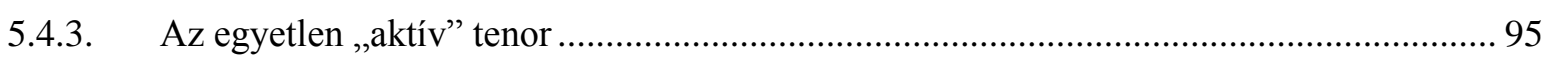

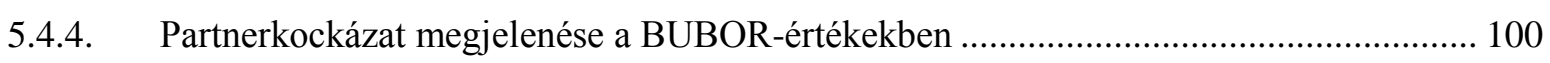

5.5. A bankok által jelentett BUBOR-értékek lehetséges anomáliáinak statisztikai modellezése ..... 103

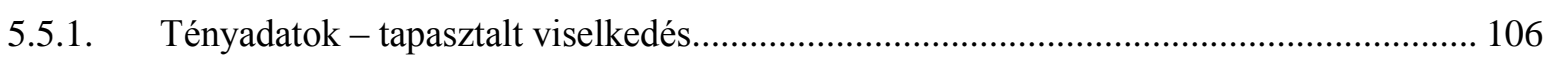

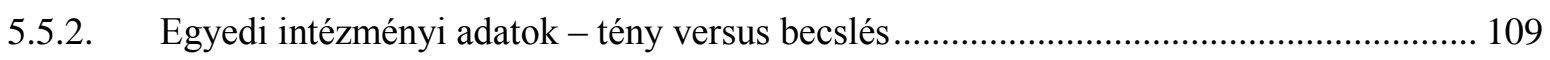

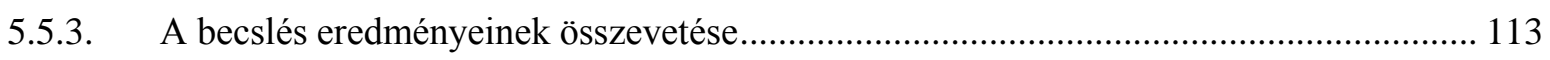

5.6. Az elemzések eredményeinek összefoglalása........................................................................... 116

5.7. A BUBOR és a banki belső folyamatok kapcsolata ................................................................. 117

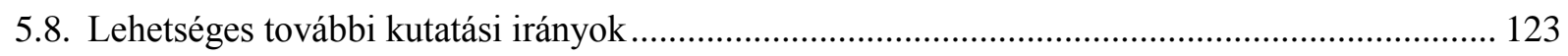

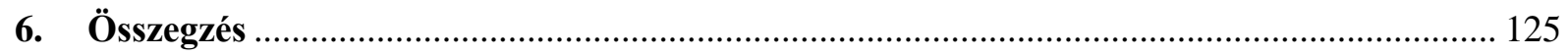

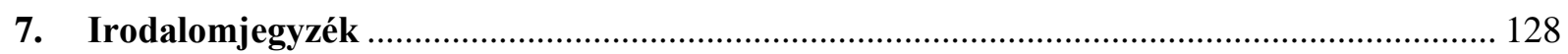

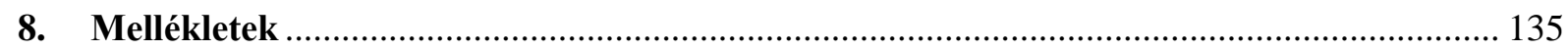

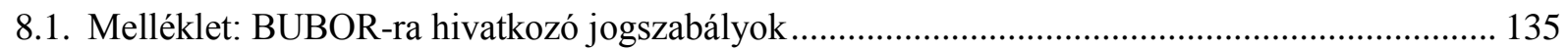

8.2. Melléklet: Az 1, 3 és 6 havi BUBOR jegyzések szórásának az idősora (bázispont)................... 140

8.3. Melléklet: A jegybanki alapkamat és az 1, 3 és 6 havi BUBOR értékek (1M, 3M, 6M) idősorának korrelációs mátrixai 2004. január - 2012. június időszakra .................................................... 142

8.4. Melléklet: A változók korrelációs mátrixa (transzformált változók)......................................... 143

8.5. Melléklet: A klasztermodellek eredményeinek összevetése a tényadatokkal - kereszttáblák ..... 144

8.6. Melléklet: Az intézmények jegyzésének eltérése a napi BUBOR értékhez képest 2006.január -

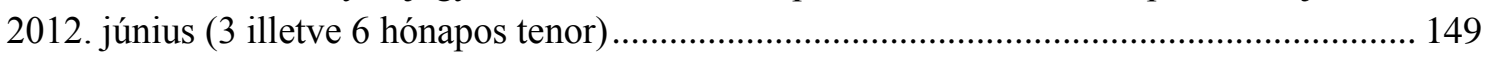

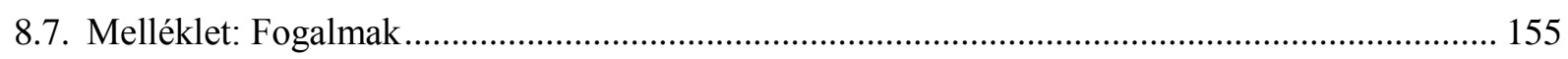

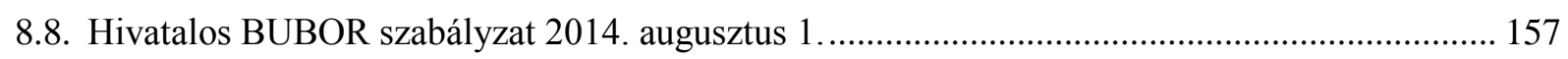

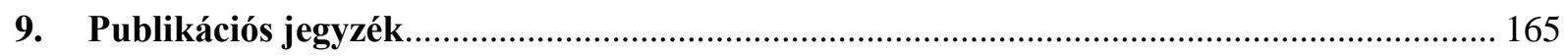

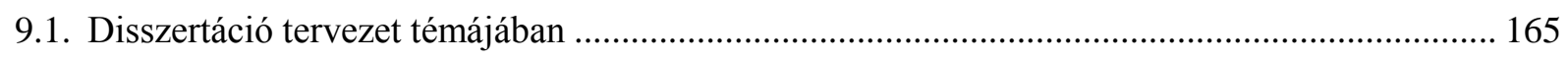

9.2. Disszertáció tervezetben felhasznált módszertanokkal kapcsolatos publikációk ......................... 165 


\section{Ábrajegyzék}

1. ábra: BUBOR-hoz kötött betétállományok és súlyuk a teljes betétállományon belül 2007. december - 2012. június (milliárd forint ill. \%) a BUBOR jegyzésében résztvevő intézmények állományi adatai alapján. 64

2. ábra: BUBOR-hoz kötött hitelállományok és súlyuk a teljes hitelállományon belül 2007. december 2012. június (milliárd forint ill. \%) a BUBOR jegyzésében résztvevő intézmények állományi adatai alapján. 64

3. ábra: BUBOR alapján árazódó jelzáloghitelek állománya 2007. december - 2012. június (milliárd forint) a BUBOR jegyzésében résztvevő intézmények állományi adatai alapján 65

4. ábra: A 3 havi referencia-kamathoz kötött nettó pozíciók (milliárd forint) alakulása a legjelentősebb piaci szereplők esetén 2009. január - 2012. június

5. ábra: A 6 havi referencia-kamathoz kötött nettó pozíciók alakulása (milliárd forint) a legjelentősebb piaci szereplők esetén 2009. január - 2012. június

6. ábra: Az O/N és 1 havi BUBOR-értékek (\%) historikus idősora 2010. október - 2011. február ...... 74

7. ábra: 3 és 6 havi BUBOR napi jegyzések szórásának idősora 2006. január - 2012. június .75

8. ábra: Az 1 havi BUBOR-jegyzések nyesés utáni szórásának historikus idősora 2006. január - 2012. június

9. ábra: A 3 havi BUBOR-jegyzések nyesés utáni szórásának historikus idősora 2006. január - 2012. június

10. ábra: A 6 havi BUBOR-jegyzések nyesés utáni szórásának historikus idősora 2006. január - 2012. június 77

11. ábra: „V” intézmény 3 havi BUBOR jegyzéseinek differencia idősora 2006. január - 2012. június 79

12. ábra: „V” intézmény 6 havi BUBOR jegyzéseinek differencia idősora 2006. január - 2012. június 80

13. ábra: „W” intézmény 3 havi BUBOR jegyzéseinek differencia idősora 2006. január - 2012. június 81

14. ábra: „W” intézmény 6 havi BUBOR jegyzéseinek differencia idősora 2006. január - 2012. június 81

15. ábra: A jegybanki alapkamat és a BUBOR (1M, 3M, 6M) értékek alakulása 2004. január - 2012. június .86

16. ábra: A 3 és 6 havi BUBOR-értékek eltérésének (bázispont) alakulása 2007. január - 2012. június

17. ábra: Az 1 és 6 havi BUBOR-értékek eltérésének (bázispont) alakulása 2007. január - 2012. június 
18. ábra: Az 1 és 3 havi BUBOR-értékek eltérésének (bázispont) alakulása 2007. január - 2012. június

19. ábra: 3 hónapos BUBOR és egyes benchmarkok alakulása 2007. január - 2012. június 91

20. ábra: 6 hónapos BUBOR és egyes benchmarkok alakulása 2007. január - 2012. június 91

21. ábra: 3 hónapos BUBOR és benchmarkok közötti korreláció 2007. január - 2012. június: bal skála - korreláció; jobb skála - alapkamat szintje \%

22. ábra: 6 hónapos BUBOR és benchmarkok közötti korreláció 2007. január - 2012. június: bal skála - korreláció; jobb skála - alapkamat szintje \% . 94

23. ábra: Az egynapos BUBOR és a jegybanki alapkamat alakulása 2006. január - 2012. június 96

24. ábra: Az egynapos BUBOR napi jegyzéseinek szórása bázispontban 2006. január - 2012. június 97

25. ábra: „W” intézmény egynapos BUBOR jegyzéseinek differencia idősora 2006. január - 2012. június 98

26. ábra: A 3 havi BUBOR - alapkamat szpred és magyar CDS felár idősor 2006. január - 2012. június 102

27. ábra: 3 hónapos BUBOR-jegyzésekből készített kontrollváltozók dendrogramja 107

28. ábra: 6 hónapos BUBOR-jegyzésekből készített kontrollváltozók dendrogramja 108

29. ábra: „A” modell (3 M) eredményének dendrogramja 114

30. ábra: „B” modell (6 M) eredményének dendrogramja 115

31. ábra: Hitelfolyósítás belső elszámolásának sematikus szemléltetése. 120

32. ábra: BUBOR-jegyzésekből készített hozamgörbe 2011. június 20. - 2011. június 24. 122

33. ábra: Az 1 havi BUBOR jegyzések szórásának idősora 2004. január - 2012. június 140

34. ábra: A 3 havi BUBOR jegyzések szórásának idősora 2004. január - 2012. június 141

35. ábra: A 6 havi BUBOR jegyzések szórásának idősora 2004. január - 2012. június 141 


\section{Táblázatjegyzék}

1. táblázat: LIBOR-jegyzésben résztvevő intézmények száma devizapanelenként 2012-ben .............. 19

2. táblázat: LIBOR-jegyzésben résztvevő intézmények száma devizapanelenként 2014-ben .............. 20

3. táblázat: A BUBOR-jegyzés főbb paramétereinek változása 1996 - 2014 ..................................... 52

4. táblázat: BUBOR-hoz kötött betét- illetve hitelállományok alakulása a BUBOR-jegyzésben

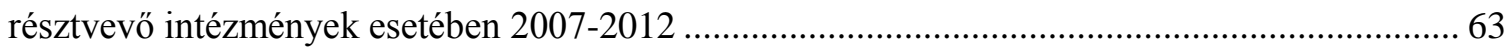

5. táblázat: Jelentősebb nettó pozícióváltozásokhoz kapcsolódó jegyzések vizsgálata...........................68

6. táblázat: 2012. január 6-i 3 havi BUBOR-jegyzések és az intézményi jegyzések néhány leíró

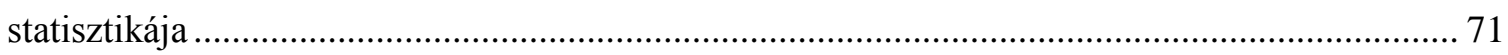

7. táblázat: Példa a BUBOR-számítás érzékenységére - az egyes szcenáriókban alkalmazott 3 havi

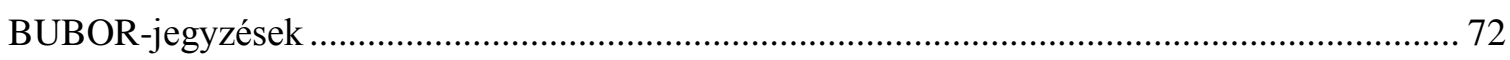

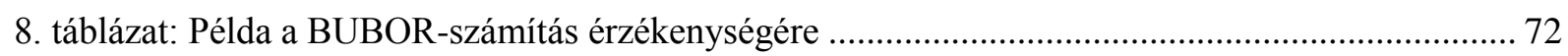

9. táblázat: „V” és „W” intézmények 3 illetve 6 havi BUBOR-jegyzések differenciáinak gyakorisági táblája 2006. január - 2012. június.

10. táblázat: „V” és „W” intézmények 3 illetve 6 havi BUBOR-jegyzések differenciáinak gyakorisági táblája 2006. január 2. - 2008. október 22.

11. táblázat: „V” és „W” intézmények 3 illetve 6 havi BUBOR jegyzések differenciáinak gyakorisági

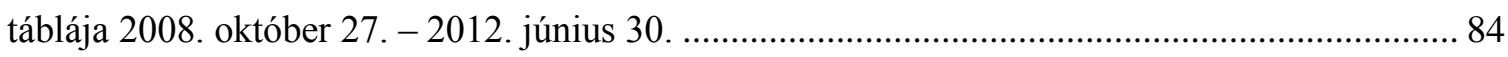

12. táblázat: Jegybanki alapkamat változások évenkénti száma $(\mathrm{db})$.................................................. 86

13. táblázat: Példa a lineáris interpoláció alkalmazására a BUBOR-jegyzésben .................................. 89

14. táblázat: A főbb BUBOR-tenorokhoz tartozó napi jegyzések szórásának középértékei és maximuma a 2006. január - 2012. június közötti időszakra, bázispontban 97

15. táblázat: Az egynapos BUBOR-jegyzések és a jegybanki alapkamat eltérésének leíró statisztikái bázispontban

16. táblázat: 3 illetve 6 havi BUBOR-jegyzések és a jegybanki alapkamat eltérésének leíró statisztikái

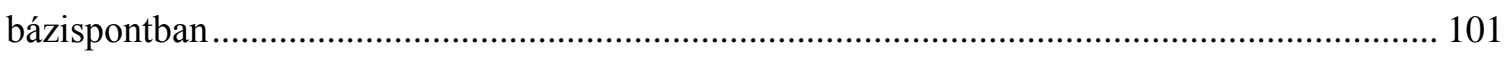

17. táblázat: A statisztikai modellezés során felhasznált nyers változók .......................................... 104

18. táblázat: A K-közép klaszterezés során felhasznált változók .................................................... 105

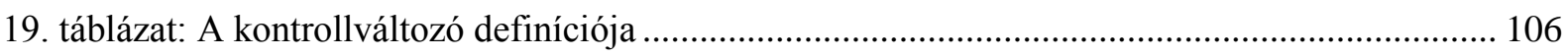

20. táblázat: Példa a BUBOR intézményi belső alkalmazása által felmerülő kérdésekre I. folyósításkor tervezett eredmény

21. táblázat: Példa a BUBOR intézményi belső alkalmazása által felmerülő kérdésekre II. - valós eredmény 


\section{Bevezetés}

A bankközi referencia-kamatlábak az egész világon meghatározó szerepet töltenek be a mindennapok pénzügyi folyamataiban. A bankközi piacokon tevékenykedő pénzintézetek egy része által létrehozott referencia-értékek a banki termékek lehető legszélesebb körében megjelennek. Nemcsak a bankközi piac ügyletei, hanem lakossági és vállalati hitel-, betéttermékek is átárazódnak az adott referencia-kamatláb alapján. Csak az amerikai dollár bankközi referencia-kamatának londoni jegyzésekhez világviszonylatban több mint 300 billió USD értékü tranzakció kapcsolódik. A Budapesten jegyzett referencia-érték alapján több mint 3000 milliárd forint értékủ vállalati és lakossági hitel, betét árazódik át.

Ezek a hatalmas számok is mutatják a bankközi referencia-kamatlábak jelentőségét, és egyben azt a tényt, hogy ezen értékek a közgazdasági folyamatok szerves részeivé váltak. Elemzésük kiemelten fontos, hiszen mind a piacról, mind a jegyzésben résztvevő piaci szereplőkről rengeteg információt közvetítenek. Ezen elemzések mind a pénzintézetek, mind a szabályozók, mind a fogyasztók számára nagy jelentőséggel bírnak. A referencia-kamatláb piacának pontosabb ismeretével egy pénzintézet (még abban az esetben is, ha a jegyzésben nem vesz részt) hatékonyabban müködhet, a szabályozó pedig piaci torzulásokra deríthet fényt. Ugyanakkor egy elemzés megerősítheti a referencia-kamat társadalmi elfogadottságát is (például alkalmazhatóságát a jelzáloghitelezésben). Ezek a tények is alátámasztják, hogy a referencia-kamatoknak a közgazdasági területen kiemelt szerepük van, és a hozzájuk kapcsolódó kutatások releváns információt hordoznak a pénzpiaci szereplők számára.

A londoni bankközi referencia-kamatláb, a LIBOR $^{1}$ előtérbe kerülése volt az alapja a doktori értekezésem témaválasztásának. 2012 nyarán ismertté vált, hogy korábban éveken keresztül a bankközi referencia-kamat jegyzését (fixing) végző londoni bankházak manipulálták a referencia-kamat rögzítési folyamatát. A manipulált eredmények következtében a londoni bankközi kamatláb szintje nem a valós piacot jelenítette meg, hanem az egyes jegyző intézmények érdekeit. Az angol felügyelet kiemelt szigorral lépett fel a manipulálásban résztvevő pénzintézetek ellen, több száz millió fontos bírságokat szabott ki, és sok esetben az érintett vezetők leváltását is elvárta (Barclays, UBS, Royal Bank of Scotland).

\footnotetext{
${ }^{1}$ London Inter-Bank Offered Rate
} 
Az értekezés során bemutatom az általam alkalmazott statisztikai módszertant, a londoni referencia-ráta jegyzésének folyamatát, az intézmények manipulálási ösztönzőit, a manipulálási botrány felszínre kerülését és a szabályozói reakciókat. A londoni bankközi referencia-kamatláb definíciójának ismertetésénél a játékelmélet eszköztárát felhasználva szemléltetem a definícióban és a hozzá kapcsolódó jegyzési szabályzatban rejlő manipulálási ösztönzőket, illetve egy leegyszerüsített példán keresztül rávilágítok a külső és belső kontrollfolyamatok jelentőségére, a szabályozó hatóság szerepére.

A szabályozó reakciók ismertetése a téma szerves része, hiszen a rövid időn belül napvilágot látott iránymutatások, elemzések hatalmas mennyisége rávilágít arra a tényre, hogy a referencia-kamatok területén a korábbi tudományos kutatások egy nagyon fontos aspektussal nem foglalkoztak. Ez pedig nem más, mint az adatok, a jegyzések megbízhatósága. Egy új terület került fókuszba, hiszen nem álltak rendelkezésre korábbi tanulmányok erről a kérdéskörröl, melyek benchmarkként használhatók lettek volna. Ezek az újkeletü dokumentumok rávilágítanak arra - a játékelméleti példában is eredményül adódó - tényre, hogy önmagában egy hatalmas bírság nem elégséges a jegyzések manipuláció-mentességének biztosítására.

Tanulmányomban a budapesti bankközi kamatláb (BUBOR) jegyzését vizsgálom részletesen. A BUBOR történetének bemutatásán túl, kitérek a kapcsolódó jogszabályi környezetre, a LIBOR-tól való fontos különbségekre is. Emellett elemzem a budapesti jegyzéseket, és mind a piac, mind az egyes szereplők viselkedésére is kitérek. Vizsgálatom során az alábbi kérdésekre keresem a válaszokat:

- A LIBOR definíciójában ténylegesen megtalálhatóak voltak manipulálásra ösztönző elemek?

- A LIBOR jegyzésével kapcsolatosan felmerült hiányosságok mekkora mértékben érintik a BUBOR-t? Mekkora a hasonlóság/különbség a BUBOR és a LIBOR között?

- Helyettesíthető-e a BUBOR valamilyen más elfogadott piaci referencia-értékkel (benchmarkkal)?

- Milyen tulajdonságai vannak a BUBOR jegyzés folyamatának? Következtethetünk-e a mögöttes termék piacára?

- A piaci jegyzésben vagy az adott jegyzést végző piaci szereplő viselkedésében azonosíthatók-e valamilyen viselkedési sémák? 
Játékelméleti eszköztár segítségével rámutatok a LIBOR definíciójában megtalálható, manipulálásra ösztönző elemekre. Bemutatom a leíró, illetve a keresztmetszeti statisztikák azon belül is a klaszterelemzés - alkalmazhatóságát a pénzpiaci szereplőknek a referenciakamat jegyzése során megvalósított viselkedésének az elemzésében. Az elemzés során rámutatok, hogy egy eddig nem vizsgált közgazdasági probléma került előtérbe, amelynél a korábbiakban alkalmazott, elsősorban idősorelemzési módszerek alkalmazhatósága jelentős korlátokba ütközik. Azt kívánom szemléltetni, hogy a felsorolt módszerek alkalmazása is segíthet ezen terület feltérképezésében, és az elemzők számára fontos információk forrásává válhat. 


\section{Módszertani keret}

Tanulmányomban a statisztikai elemzés előtt a londoni bankközi referencia-kamatláb manipulálási botrányának és az arra adott szabályozói reakcióknak a bemutatása közben részletesen kitérek a LIBOR definíciójára és jegyzési folyamatára. A LIBOR-definíció mentén egy „leegyszerűsített” jegyzési környezetben játékelméleti megközelítésben kiemelem a definíció és a jegyzési folyamat gyengeségeit. Egyszerü példán keresztül szemléltetem, hogy az igazmondás dominált stratégiává válhat akár egyetlen feltétel sérülése esetén is. Eszerint egy, a kamatjegyzést modellező nem-kooperatív szimultán játékban a szereplőknek (a kamatjegyzésben résztvevő intézményeknek) mindenképpen kifizetődőbb eltérni az igazmondás stratégiájától. Belátható, amennyiben minden szereplő ugyanazt a feltételezést sérti meg, a szimultán döntésük eredménye egy olyan domináns Nash-egyensúly lehet, amelyben egyik résztvevő sem a valós értéket jelenti. A budapesti bankközi forint hitelkamatláb definíciójának és jegyzési folyamatának bemutatása során kiemelem, hogy a LIBOR-hoz képest mely lehetséges ösztönzők állnak fenn a játékelméleti kontextusban is szemléltetettek közül.

\subsection{Játékelmélet}

A dolgozatomban kizárólag nem kooperatív modelleket alkalmazok, ezért a definíciók megadásánál a nem kooperatív játékok normál formáját használom. Ezeknek a modelleknek 3 összetevőjük van:

- a játékosok listája

- minden játékos stratégiáinak a listája

- a játékosok által kapott kifizetések listája minden olyan stratégia-együttes esetén, mely minden játékosnak pontosan egy stratégiáját tartalmazza

$A G=\left\{S 1, \ldots, S n ; f_{1}, \ldots, f_{n}\right\}$ struktúrát játéknak (n-szereplős) nevezzük, ahol $S_{i}$ az i-edik játékos nem üres stratégiahalmaza, $\mathrm{f}_{\mathrm{i}}: \mathrm{S} \rightarrow \mathrm{R}$ pedig a kifizető függvénye, ahol $\mathrm{S}=\mathrm{S}_{1} \times \ldots \times \mathrm{S}_{\mathrm{n}}$. Oligopol játék esetén az $\mathrm{S}_{\mathrm{i}}$ elemei pl.: jegyezhető kamatszintek, $\mathrm{f}_{\mathrm{i}}$ pedig a profitfüggvény.

A későbbi példákban kizárólag nem kooperatív szimultán játékokat használok, vagyis a játékosok egyidejüleg hozzák meg a döntéseiket és a döntéseiknél kevert stratégiákat nem alkalmazhatnak.

A stratégiák vizsgálatánál fontos a dominancia fogalma: legyen G egy normál formában adott n-szereplős játék, legyen $\mathrm{s}_{\mathrm{i}} ; \mathrm{t}_{\mathrm{i}}$ az i-edik játékos két tiszta stratégiája;

- $\mathrm{s}_{\mathrm{i}}$ szigorúan dominálja $\mathrm{t}_{\mathrm{i}-\mathrm{t}}$, ha $\mathrm{f}_{\mathrm{i}}\left(\mathrm{s}_{\mathrm{i}} ; \mathrm{s}_{-\mathrm{i}}\right)>\mathrm{f}_{\mathrm{i}}\left(\mathrm{t}_{\mathrm{i}} ; \mathrm{s}_{-\mathrm{i}}\right)$ minden $\mathrm{s}_{-\mathrm{i}} \in \mathrm{S}_{-\mathrm{i}}$ esetén; 
- $\quad \mathrm{s}_{\mathrm{i}}$ gyengén dominálja $\mathrm{t}_{\mathrm{i}} \mathrm{t}$, ha $\mathrm{f}_{\mathrm{i}}\left(\mathrm{s}_{\mathrm{i}} ; \mathrm{s}_{-\mathrm{i}}\right) \geq \mathrm{f}_{\mathrm{i}}\left(\mathrm{t}_{\mathrm{i}} ; \mathrm{s}_{-\mathrm{i}}\right)$ minden $\mathrm{s}_{-\mathrm{i}} \in \mathrm{S}_{-\mathrm{i}}$ esetén, és létezik $\left(\mathrm{t}_{\mathrm{i}} ; \mathrm{s}_{-}\right.$ i), hogy az egyenlőtlenség szigorú,

ahol $\mathrm{S}_{-\mathrm{i}}$ azoknak a stratégiaprofiloknak a halmaza, melyek nem tartalmazzák az i-edik játékos stratégiáit.

A legjobb-válasz leképezés az i-edik játékos azon stratégiáit adja meg, melyek a lehető legmagasabb kifizetést eredményezik a játékos számára, feltéve, hogy a többiek egy adott stratégiaprofil szerint cselekednek. Ez formálisan a következő $B_{\mathrm{i}}: S \rightarrow S_{\mathrm{i}}$ leképezés:

$$
B_{i}(s)=\left\{t_{i} \in S_{i} \mid f_{i}\left(t_{i} ; s_{-i}\right) \geq f_{i}\left(r_{i} ; s_{-i}\right), \text { minden } r_{i} \in S_{i}\right. \text {-re. }
$$

Nash révén egy játék egyensúlyának kiválasztásánál a koncepció a stabilitás lett. (Nash [1950]) Egy játék megoldását akkor tekinthetjük stabilnak, ha tetszőleges i játékos nem tudja a kifizetését növelni azáltal, hogy a saját stratégiáját megváltoztatja, miközben a többiek nem változtatnak a stratégiájukon. Vagyis az i játékos a legjobb válaszát adja a többiek feltételezett stratégiájára. Ezt a tulajdonságot adja vissza a Nash-egyensúly definíciója:

Legyen $G$ egy n-személyes nem kooperatív játék normál formában adott. Az s* tiszta stratégiákból álló stratégiaprofil Nash-egyensúly a játékban, ha a következő egyenlőtlenség fennáll:

$$
\mathrm{fi}\left(\mathrm{s}_{\mathrm{i}} ; \mathrm{s}_{-\mathrm{i}}\right) \geq \mathrm{f}_{\mathrm{i}}\left(\mathrm{s}_{\mathrm{i}} ; \mathrm{s}_{-\mathrm{i}}\right)
$$

minden $\mathrm{s}_{\mathrm{i}} \in \mathrm{S}_{\mathrm{i}}$ és minden $\mathrm{i}=1, \ldots, \mathrm{n}$ esetén. Szavakkal megfogalmazva: egy $\mathrm{s}^{*}$ stratégiaprofil Nash-egyensúly a játékban, ha a játékosok kölcsönösen a legjobb válaszukat adják a többiek cselekvésére. Ha az egyensúlyban minden játékos domináns stratégiát választ, akkor domináns Nash-egyensúlyról beszélünk. ${ }^{2}$

\subsection{Statisztika}

A statisztikai elemzés során a játékelméleti eszközökkel is azonosított ösztönzőkre fókuszálok, valamint vizsgálom a jegyzési módszertan erősségeit/gyengeségeit. Célom, hogy megmutassam a leíró statisztikai mutatószámok hasznosságát. Az aktív kamatjegyző ${ }^{3}$ intézmények által jelentett referencia-értékekből képzett sokaságok eloszlási paraméterei rengeteg információt hordoznak az elemző számára. A középértékek, a szélső értékek vagy a szórás vizsgálata fontos összefüggésekre világítanak rá. A vizsgálatok során kitérek az aktív kamatjegyző intézmények főbb lejárati időpontokra (tenor) ${ }^{4}$ vonatkozó jegyzéseinek

\footnotetext{
${ }^{2}$ A definíciók megadásánál Forgó et al. [2005] jelölését követtem.

${ }^{3}$ Definíciót lásd 8.7. Melléklet.

${ }^{4}$ Definíciót lásd 8.7. Melléklet.
} 
differencia idősorára is. Emellett nem hagyható figyelmen kívül ezen módszereknek az a hatalmas elönye, hogy könnyen interpretálhatók.

Az alternatív benchmark értékek vizsgálatánál a jegybanki alapkamattól való eltérések időbeli alakulását vizsgálom. Emellett diszjunkt időtávokon képzett korrelációs értékek alapján is következtetek a budapesti referencia-kamatláb viselkedésére. Az alternatív benchmark értékek és a tényleges BUBOR jegyzések közötti korrelációk változásának vizsgálatával a referenciakamatlábat érintő összetételhatásokat elemzem. Erhart, Ligeti és Molnár (Erhart-LigetiMolnár [2013]) megmutatta, hogy a 3 hónapos referencia-kamat idősora nagyon erős autoregresszív tulajdonságokkal rendelkezik és AR(1) folyamattal jól leírható. A 0,99 feletti együttható értékek arra sarkalltak, hogy tanulmányomban ne OLS becslést, vagy egyéb idősorelemzési módszertant kövessek, hanem rámutassak a leíró statisztikai mutatószámok hasonló erősségü alkalmazhatóságára.

Az elemzés során további célom az, hogy az intézmények jegyzési viselkedését is vizsgáljam. A leíró statisztikák segítségével rámutatok, hogy ez nem is olyan egyszerủ dolog, hiszen viselkedési struktúrákat kell feltárni. Az elemzésemből kiderül, hogy eseti „szándékolt” szélsőséges jegyzések nem azonosíthatók. Az egyedi jegyzések azon tulajdonsága miatt, hogy a jegyzési folyamatban nagyon erős az autokorreláció, a viselkedések elemzésénél az a célom, hogy a K-közép klaszterelemzés felhasználásával azonosítsak olyan változókat, amelyek segítségével következtethetünk arra, hogy az adott intézmény napi jegyzése milyen mértékben viszonyul a többi kamatjegyző intézmény napi jegyzéséhez. Ennek eléréséhez a célváltozómat átskáláztam három kategóriával rendelkező ordinális változóvá. Az intézmények napi jegyzéseit aszerint sorolom be, hogy az adott napon átlag feletti, átlagos vagy átlag alatti értéket jelentett-e a vizsgált aktív kamatjegyző intézmény. A választott módszertan validálása érdekében a klaszterelemzést a célváltozóra hajtom végre. Az alternatív benchmarkok felhasználásával klaszterelemzést végzek, amelynek eredményét összevetem az intézmények tényleges jegyzéseivel.

\section{Klaszterelemzés}

Az elemzés során kétlépéses klaszterelemzést végeztem. Az első lépésben az intézményre ható külső (piaci benchmarkok) és belső (saját derivatív pozíciók) hatások alapján a kereskedési napokat K-közép klaszter módszertannal három kategóriába soroltam. Az eltérő mértékegységek miatt a változókat sztenderdizáltam. Ezzel a becsléssel előállítom a tényjegyzésekből képzett ordinális célváltozó alternatív megfelelőjét. 
A K-közép módszertan algoritmusa három fő lépésből áll. A lépések ismertetéséhez tegyük fel, hogy $\mathrm{N}$ darab klasztert szeretnénk generálni. Jelölje $\mathrm{M}_{\mathrm{i}}$ az i-edik klaszter átlagát, $\mathrm{x}_{\mathrm{k}} \mathrm{a}$ kadik megfigyelés vektorát, $\mathrm{d}\left(\mathrm{x}_{\mathrm{i}}, \mathrm{x}_{\mathrm{j}}\right)$ a két megfigyelés-vektor közötti euklideszi távolságot, $\mathrm{d}_{\text {min }}$ az $\mathrm{M}_{\mathrm{i}}$ és $\mathrm{M}_{\mathrm{j}}$ közötti euklideszi távolságok minimumát és $\varepsilon$ a konvergencia kritériumot.

\section{- Kezdeti klaszterközéppontok kiválasztása}

Az eljárás kezdete során az első $\mathrm{N}$ elem tekintendő klaszterközéppontnak, amennyiben egyik sem hiányzó érték. Ezután az alábbi algoritmus alkalmazandó a további megfigyelésekre:

○ Ha $\min _{\mathrm{i}} \mathrm{d}\left(\mathrm{x}_{\mathrm{k}}, \mathrm{M}_{\mathrm{i}}\right)>\mathrm{d}_{\min }$ és $\mathrm{d}\left(\mathrm{x}_{\mathrm{k}}, \mathrm{M}_{\mathrm{m}}\right)>\mathrm{d}\left(\mathrm{x}_{\mathrm{k}}, \mathrm{M}_{\mathrm{n}}\right)$, akkor $\mathrm{x}_{\mathrm{k}}$ helyettesítse $\mathrm{M}_{\mathrm{n}}-\mathrm{t}$. Ha $\min _{\mathrm{i}} \mathrm{d}\left(\mathrm{x}_{\mathrm{k}}, \mathrm{M}_{\mathrm{i}}\right)>\mathrm{d}_{\min }$ és $\mathrm{d}\left(\mathrm{x}_{\mathrm{k}}, \mathrm{M}_{\mathrm{m}}\right)<\mathrm{d}\left(\mathrm{x}_{\mathrm{k}}, \mathrm{M}_{\mathrm{n}}\right)$, akkor $\mathrm{x}_{\mathrm{k}}$ az $\mathrm{M}_{\mathrm{m}}$-mel helyettesítendő. Amennyiben $\mathrm{x}_{\mathrm{k}}$ és a legközelebbi klaszter távolságának átlaga nagyobb, mint a két legközelebbi klaszter-átlag közötti távolság, akkor mind $\mathrm{M}_{\mathrm{n}}$, mind $\mathrm{M}_{\mathrm{m}}$ helyettesíthető $\mathrm{x}_{\mathrm{k}}$-val.

- Ha a fenti algoritmus alapján $\mathrm{x}_{\mathrm{k}}$ egyik klaszterátlagot sem helyettesíti, akkor az alábbi teszt vizsgálandó. Jelölje $\mathrm{M}_{\mathrm{q}}$ az $\mathrm{x}_{\mathrm{k}}$-hoz legközelebbi klaszterátlagot, $\mathrm{M}_{\mathrm{p}}$ pedig a második legközelebbit. $H a d\left(x_{k}, M_{p}\right)>\min _{i} d\left(M_{q}, M_{i}\right)$, akkor legyen $M_{q}$ $=\mathrm{x}_{\mathrm{k}}$. Amennyiben $\mathrm{x}_{\mathrm{k}}$ távolabb van a második legközelebbi klaszterközépponttól, mint amilyen távol van a legközelebbi klaszterközéppont bármely másik klaszterközépponttól, akkor a legközelebbi klaszter középpontját helyettesítse $\mathrm{x}_{\mathrm{k}}$.

\section{- Klaszterközéppontok újraszámolása}

Az első iterációs lépéstől kezdve, minden esetben meghatározandó a legközelebbi klaszter, és a klaszterközép újraszámolásra kerül. A módosított klaszterátlagok lesznek a kapott besorolás klaszterközéppontjai.

- Elemek besorolása a legközelebbi klaszterbe

Végső lépésként az elemek besorolása a legközelebbi klaszterbe az újraszámolt klaszterközéppontok és a megfigyelések euklideszi távolsága alapján történik. Minden megfigyelés a hozzá legközelebb eső klaszterközép alapján kerül besorolásra. A végső klaszterközepek az adott klaszterbe sorolt megfigyeléseknek a klaszterezéshez felhasznált változók esetében felvett értékeik átlagaként adódnak. 
A fenti lépésekből álló iterációs folyamat abban az esetben áll meg, ha az iterációk száma eléri a beállított maximális értéket, vagy két egymást követő iteráció esetében a klaszterközepek változása az $\varepsilon$ konvergencia értéken belül marad.

A K-közép algoritmussal külön-külön hierarchikusan klaszterezem a becsült, illetve a tényleges intézményenkénti három kategóriával rendelkező ordinális változókat. A hierarchikus klaszterezés a hasonlósági (vagy különbözőségi) távolság mértékeken alapuló eljárás. Az elemzés kiindulási pontja a hasonlósági mértékek $\mathrm{S}$ mátrixa, melynek $\mathrm{S}_{\mathrm{ij}}$ eleme jelölje az i-edik és a j-edik klaszter közötti hasonlósági mértéket.

A hasonlóság mérésére - mivel a változóim nem intervallum- vagy arányskálán mértek - a khi-négyzet mértéket alkalmaztam:

$$
\chi^{2}=\sum_{r=1}^{K_{k}} \sum_{s=1}^{K_{l}} \frac{\left(n_{r s}-M_{r s}\right)^{2}}{M_{r s}}
$$

ahol $\mathrm{K}_{\mathrm{k}}$ a k-adik változó kategóriáinak száma, $\mathrm{K}_{1}$ az l-edik változó kategóriáinak a száma, $\mathrm{n}_{\mathrm{rs}} \mathrm{a}$ gyakorisági tábla $\mathrm{r}$-edik sorának s-edik eleme. $\mathrm{M}_{\mathrm{rs}}$ a két változó függetlensége esetén a várt gyakoriság, vagyis $M_{r s}=\frac{n_{r+}+n_{s+}}{n}$, ahol $\mathrm{n}_{\mathrm{r}+}$ és $\mathrm{n}_{\mathrm{s}+}$ a marginális gyakoriságok vagyis $n_{r+}=$ $\sum_{s=1}^{K_{l}} n_{r s}$ illetve $n_{r+}=\sum_{r=1}^{K_{k}} n_{r s}$.

A $v_{k i}$ és $v_{k j}$ kategóriák k-adik változó szerinti különbözőségének vizsgálatához egy 2 x $K_{1}$ dimenziós kontingencia táblából indulunk ki, ahol $\mathrm{K}_{1}$ az l-edik változó kategóriáinak a száma. Ekkor a khi-négyzet különbözőségi mérték az alábbi formában írható:

$$
D_{C S}\left(v_{k i}, v_{k j}\right)=\sqrt{\chi^{2}}=\sqrt{\sum_{s=1}^{K_{l}} \frac{\left(n_{i s}-M_{i s}\right)^{2}}{M_{i s}}+\sum_{s=1}^{K_{l}} \frac{\left(n_{j s}-M_{j s}\right)^{2}}{M_{j s}}}
$$

ahol $M_{i s}=\frac{n_{i+}\left(n_{i s}+n_{j s}\right)}{n_{i+}+n_{j+}}$ és $M_{j s}=\frac{n_{j+}\left(n_{i s}+n_{j s}\right)}{n_{i+}+n_{j+}}$.

Az összevonási eljárás az alábbi általános lépéseken alapul $\mathrm{N}$ darab klasztert/változót feltételezve:

- Az eljárás kezdetén minden változó egy külön klaszter.

- A változók közötti hasonlósági (különbözőségi) NxN-dimenziós S mátrix előállítása.

- A leghasonlóbb két klaszter ( $\mathrm{p}$ és q) megkeresése, ahol p > q. A hasonlósági mértéküket jelölje $S_{\mathrm{pq}}$. Amennyiben különbözőségi mértéket használunk, a nagyobb érték alacsonyabb fokú hasonlóságot jelöl. Ilyen a khi-négyzet is $\left(\mathrm{D}_{\mathrm{CS}}\right)$. 
- A klaszterek számának csökkentése a p és q klaszterek összevonásával. Az új klasztert jelölje t. A klaszterek közötti hasonlósági mértékek újraszámolása.

- A fenti lépések megismétlése, míg egyetlen klaszter nem marad.

A legtávolabbi szomszéd elv az alábbi meghatározáson alapul:

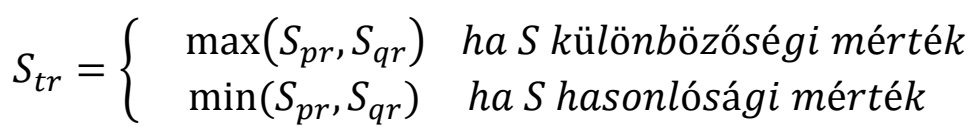

Az összevonó eljárások közül a legtávolabbi szomszéd elvet (complete linkage) alkalmazom. Ezen eljárás tulajdonsága, hogy két klaszter távolsága a klaszterek legtávolabbi elemeinek a távolsága alapján adódik. A legtávolabbi szomszéd elv különösen érzékeny az outlier-ekre, a „kilógó” értékekre.

A választott módszertanok és az elemzésekben alkalmazott benchmark értékek kiválasztásánál a referencia-kamatjegyzést végző magyarországi szakemberekkel való interjúkra támaszkodtam. Az interjúkon kapott információk jelentős segítséget nyújtottak az elemzés során felmerülö alternatív lehetőségek közötti választáshoz. 


\section{A londoni bankközi referencia-kamatláb}

\subsection{A londoni bankközi referencia-kamatláb definíciója}

A londoni bankközi referencia-kamatláb (London Interbank Offered Rate - LIBOR) globális szinten - a leggyakrabban használt referencia-kamatláb, mely legalább 300 billió amerikai dollár értékü tranzakció alapja. 2012-ben a LIBOR jegyzése 10 devizában történt 15 különböző lejárattal (egy naptól kezdve egészen az egy éves lejáratig - O/N, 1- 2 hét,1-2-3-45-6-7-8-9-10-11-12 hónapos futamidőkön) a Brit Bankszövetség (British Bankers' Association) által évente kiválasztott bankok közremüködésével (pl. az angol font esetén 16, az amerikai dollár esetén pedig 18 intézmény bevonásával). A botrány által kiváltott reformokig a jegyzési folyamatban az angol szabályozó, a Bank of England nem vett részt. Az adatokat a Thomson Reuters kérte be, összesítette és publikálta.

1. táblázat: LIBOR-jegyzésben résztvevő intézmények száma devizapanelenként 2012-ben

\begin{tabular}{lcccccccccc}
\hline & CHF & EUR & GBP & JPY & USD & AUD & CAD & DKK & NZD & SEK \\
\hline $\begin{array}{l}\text { Jegyzésben résztvevő } \\
\text { intézmények száma }\end{array}$ & 11 & 15 & 16 & 13 & 18 & 7 & 9 & 6 & 7 & 6 \\
\hline
\end{tabular}

forrás: BBA, saját szerkesztés

A LIBOR-jegyzés során a kamatjegyző bankoknak az alábbi kérdésre kellett naponta válaszolniuk:

„Milyen kamatláb mellett juthatna a jegyzést végző bank fedezetlen bankközi forráshoz releváns piaci mértékben délelőtt 11 órakor? "5

A definíció kulcsindikátorainak az alábbiak tekinthetők:

- Fedezetlen bankközi forrás - a pénzintézet piaci megítélése határozza meg a forrás árát. Amennyiben a piac kockázatosnak ítéli az aktív kamatjegyző intézményt, drágábban jut fedezetlen forráshoz.

- Jegyzést végző bank - meghatározó piaci szereplők közötti ügyletek veendők alapul a jegyzési folyamathoz, hiszen egy kis, a bankközi piacon kevésbé aktív intézmény a releváns piaci árazásról kevesebb információval rendelkezik.

\footnotetext{
${ }^{5}$ The rate at which an individual contributor panel bank could borrow funds, were it to do so by asking for and then accepting interbank offers in reasonable market size, just prior to 11.00 am London time? (BBA [2014]: http://www.bbalibor.com/explained/definitions)
} 
- Releváns piaci mérték - a jegyzést végző bankok müködésében meghatározó összegnagyságot elérő ügyeletek kerüljenek figyelembe vételre.

A kulcstényezők kiemeléséből is látható, hogy a jegyzést végző bankoknak valójában a saját piaci megítélésükről is véleményt kell formálniuk, és ezt nyilvánosságra is kell hozniuk a saját LIBOR-jegyzésükön keresztül. Vagyis a jegyzéseknél nem kizárólag csak a profit érdekek jelennek meg, hanem reputációs kérdések is, mivel a valóstól eltérő értékek jegyzésével egy aktív kamatjegyző intézmény képes elrejteni a saját kedvezőtlen piaci megítélését is. A LIBOR jegyzésének folyamatát megalkotók jóhiszemüen ez utóbbi szempontot kevésbé vették számításba.

A 2012-ben kitört botrány hatására a LIBOR jegyzését 2014. február 1-én az ICE Benchmark Administration (IBA) vette át. 2014-től a jegyzés 5 devizára és devizánként 7 lejáratra $(\mathrm{O} / \mathrm{N}$, 1 hét,1-2-3-6-12 hónap) történik. Az egyes devizák esetén 11-18 intézmény vett részt a jegyzésben.

2. táblázat: LIBOR-jegyzésben résztvevő intézmények száma devizapanelenként 2014-ben

\begin{tabular}{lccccc}
\hline & CHF & EUR & GBP & JPY & USD \\
\hline $\begin{array}{l}\text { Jegyzésben résztvevő } \\
\text { intézmények száma }\end{array}$ & 11 & 15 & 16 & 13 & 18 \\
\hline
\end{tabular}

forrás: IBA, saját szerkesztés

A londoni irányadó bankközi kamatláb számítása matematika szemszögből egyszerüen egy nyesett számtani átlagként adódik, mégpedig úgy, hogy lejáratonként a jegyzések alsó, illetve felső 25\%-át lenyesik és a maradék jegyzések számtani átlagaként határozzák meg a LIBORt. Például, 16 kamatjegyző esetén a legkisebb és a legnagyobb 4-4 jegyzés kerül elhagyásra.

A fenti nyesés képes korlátozni a profitérdek megjelenését, hiszen önmagában egy intézmény adott irányú túl- vagy aluljegyzése még nem okoz jelentős elmozdulást a referencia-kamatláb szintjében, hiszen egy szélsőséges jegyzés a nyesés során kiesik, így hatása jelentősen lecsökken. A LIBOR szintjének jelentősebb elmozdításához több intézmény kooperációja szükséges. Ugyanakkor a reputációs kérdés esetén a nyesés már nem nyújt igazi megoldást, hiszen még egy kieső jegyzés esetén is képes az aktív kamatjegyző intézmény kedvezőbb kép kialakítására önmagáról. A gyakorlatban a fenti két érdek egyszerre jelenik meg, jelentős ösztönzőket teremtve a piaci szereplők számára a jegyzés manipulálására. Ezeknek a múltban sokan nem is tudtak ellenállni. 
A manipulálhatóságot megkönnyíti, hogy a jegyzés lényegében a résztvevő bank véleményének tekinthető, és nem kapcsolódik szorosan valós üzletkötésekhez. Emellett a jegyzést végzők pontosan ismerik a számítási folyamatot, így a résztvevők bizonyos szintü kooperációja mellett a manipulálás eredményét is kellően pontosan elöre meg tudják határozni. Egy ilyen esetben azonban már sok esetben kérdéses, hogy a döntéshozók fel tudják-e mérni annak is a következményeit, hogy egy piaci bizalmat elvesztett referencia-ráta helyettesítése vagy a piaci bizalom helyreállítása mekkora társadalmi költségekkel járna. Vagyis amikor az esetleges manipulálásról döntenek, az igenhez és a nemhez kapcsolódó „költségek” csak egyik esetben mérhetők fel kellően pontosan, a másik esetben jelentős szubjektív elemek is torzíthatják a döntéshozó információit.

\subsubsection{A LIBOR-definícióból származó manipulálási ösztönzők játékelméleti megközelítésben ${ }^{6}$}

A következőben rövid levezetés révén bemutatom a LIBOR definíciójához kapcsolódó a kamatjegyzést végző intézmények esetében felmerülő manipulálási ösztönzőket. A manipuláció választásának lehetőségét játékelméleti eszköztárral korábban többen is vizsgálták (például Haaker [2013] és Diehl [2013]) 7, a későbbi elemzéshez azonban számomra elegendő ezen ösztönzők egyszerübb eszközökkel történő szemléltetése is, így a játékelméleti cikkektől részben eltérő megközelítést alkalmazok, melynél minimális mértékben a többi piaci szereplő által birtokolt információ is megjelenik.

Az egyszerüsítés kedvéért felteszem, hogy a kamatjegyzési folyamatban hat8 intézmény (A, B, C, D, E, F) vesz rész, melyek jegyzései közül a legmagasabb, illetve a legalacsonyabb értéket hagyjuk el. A maradék négy egyszerű számtani átlaga jelentse a napi rögzített referencia értéket. A referencia-kamat rögzítési eljárása során az aktív kamatjegyző intézmények szimultán határozzák meg az egyedi jegyzéseiket. Emellett tegyük fel, hogy adott egy tartomány, melynek bármely értékét jelenti is az aktív kamatjegyző intézmény, a jegyzés valódiságát sem a többi kamatjegyző sem a felügyeleti hatóság nem kérdőjelezi meg,

\footnotetext{
${ }^{6}$ A játékelméleti eszköztár alkalmazása erősnek tünhet, ugyanakkor mindenképpen indokoltnak tartom a megemlítését, mivel kiváló eszköztárt nyújt a jövőbeli kutatásokhoz a problémakör egyes részeire fókuszálva. Esetünkben a játékelméleti eszköztár alkalmazásának célja, hogy rávilágítsak a manipulatív ösztönzők jelenlétére, és ehhez két lehetséges stratégia is elegendő. Nem célom az optimális manipulatív jegyzés adott feltételek közötti meghatározása. Ezen fejezet jelentős alapját képezi a Fliszár [2016] jövőben megjelenő tanulmányának.

${ }^{7}$ Haaker kétszereplős játék esetén szemléltette játékelméleti eszköztárral a manipulálási problémát (Haaker [2013]). Haaker modelljén túlhaladva Diehl a tanulmányában meghatározott játékban már a nyesési mechanizmus is megjelenik (Diehl [2013]).

${ }^{8}$ A hat aktív kamatjegyző feltételezése a szerző önkényes választása. A nyesési mechanizmus megjelenítéséhez 4 kamatjegyző feltételezése minimális feltétel.
} 
vagyis a rendelkezésre álló információik alapján nem tudják megállapítani, hogy $\mathrm{F}$ igazat mond-e vagy manipulál. Jelölje az így választható kamatszintek tartományát $[\mathrm{L}, \mathrm{U}]$, ahol L, U $\geq 0$ és $U>$ L, vagyis nem kizárólag egy ilyen kamatszint létezik az adott kereskedési napon. Továbbá felteszem, hogy az L és U kamatszintet pontos értékét $\mathrm{F}$ intézmény sem ismeri9, ugyanakkor a $\mathrm{V}$ valós értékre10 igazak az alábbiak: $\mathrm{L}<\mathrm{V}<\mathrm{U}$.

\section{Profitabilitási ösztönzö}

Az F intézménynek csak a saját piaci pozícióiról van teljes információja. Az aktuális bankközi pozícióit figyelembe véve a magasabb referencia-kamat érték nagyobb bevételt eredményez (ezzel analóg módon az alacsonyabb kisebb profitot vagy netán veszteséget is). Az F feltételezi, hogy a többi intézmény a valós értéket jelenti, és ezen a viselkedésén nem is változtat.

Az egyszerüség kedvéért tegyük fel, hogy $\mathrm{F}$ csak két saját referencia-kamatjegyzés közül választhat: egyrészt a valós érték $(\mathrm{V})$, másrészt - megsértve a referencia-érték jegyzési szabályzatát - egy manipulált érték $(M)$ közül. Legyen $V<M$, és tegyük fel továbbá, hogy az $\mathrm{M}$ érték sem tér el olyan mértékben a V-től, hogy az a felügyeleti hatóságban vagy más aktív kamatjegyzőben megkérdőjelezné $F$ jegyzésének a hitelességét, vagyis legyen $M \leq U$. (Itt kiemelendő, hogy már néhány bázispontos elmozdulással is jelentős bevételre lehet szert tenni a bankközi piacon.)

Emellett felteszem, hogy M a legnagyobb olyan érték, amelyről F biztosan tudja, hogy eleme $\mathrm{a}[\mathrm{V}, \mathrm{U}]$ intervallumnak. Amennyiben $\mathrm{V}$-t jelent, a kifizetése $\mathrm{x}^{11}, \mathrm{M}$ jegyzése esetén pedig $\mathrm{x}+$ $\mathrm{y}$, ahol $\mathrm{y} \geq 0$, hiszen a feltételek rögzítik, hogy magasabb referencia-érték nagyobb profitot eredményez F számára. Egyenlőség lehetséges, mert előfordulhat, hogy mind a $\mathrm{V}$, mind az $\mathrm{M}$ jegyzés a nyesés során kiesik az átlagolásból. Mivel az M jegyzés mértéke nem kelt gyanút, F-nek nem kell attól sem tartania, hogy a későbbiekben a többi bank változtat a viselkedésén. Ekkor F számára az M választása egy domináns stratégia.

Mivel a szereplők helyzete a játékban szimmetrikus (annyi különbséggel, hogy egyes intézmények számára az alacsonyabb referencia-érték lehet a kedvezőbb), amennyiben a

\footnotetext{
${ }^{9}$ Ebböl következik, hogy a többi kamatjegyzö intézmény sem ismerheti, hiszen F kamatjegyzést befolyásoló tulajdonságairól nem rendelkezhetnek több információval F-nél. Ugyanakkor F számára sem ismert, hiszen a felügyelő hatóság belső ellenőrzési mechanizmusait sem ismeri $\mathrm{F}$ teljes körüen. F-nek bizonyára van erről vélekedése, de ez egyáltalán nem biztos, hogy egybeesik a valós L és U értékekkel.

${ }^{10} \mathrm{~V}$ azt a tényleges, valós és az intézmény számára legkedvezőbb kamatszintet jelöli, melyen a kamatjegyző intézmény fedezetlen bankközi forráshoz lenne képes jutni a jegyzés definíciójában megadott időpontban

${ }^{11} \mathrm{x}$ negatív értéket is felvehet. Ekkor a manipulált jegyzéssel a kamatjegyző intézmény a veszteséges müködését is képes lehet leplezni.
} 
szabályzatot megsértve a saját pozícióikat is figyelembe veszik, az igazmondás stratégiáját dominálja a manipulálás. Amennyiben eltekintünk a kooperáció lehetőségétől, és minden szereplő a döntésénél a saját piaci pozícióiból indulna ki, a hat szereplős szimultán játéknak a Nash-egyensúlyában minden szereplő manipulálna, vagyis senki sem mondana igazat ${ }^{12}$.

Fontos hangsúlyozni, hogy amennyiben létezne $\mathrm{N}=\mathrm{M}+\varepsilon$ jegyzés, ahol $\varepsilon \geq 0$ és $\mathrm{N}$ szintén benne van a $[\mathrm{V}, \mathrm{U}]$ intervallumban, akkor $\mathrm{N}$ jegyzés választása gyengén dominálná $\mathrm{M}$ választását, vagyis $\mathrm{F}$ nem járna rosszabbul, ha $\mathrm{N}-\mathrm{t}$ mond $\mathrm{M}$ helyett. Ha feloldanánk a feltevésünket és $\mathrm{F}$ ismerné az U-t, akkor a fentiekhez hasonlóan belátható, hogy U lenne az optimális választás ${ }^{13}$.

\section{Az intézmény piaci pozíciójának jelzése}

Egy másik ösztönző nem magában a jegyzési folyamatban, hanem a LIBOR-nak a definíciójában rejlik. A definíció szerint az aktív kamatjegyző intézménynek arról kell nyilatkoznia, hogy milyen áron jutna fedezetlen forráshoz a bankközi piacon ${ }^{14}$. Egy nagyobb érték azt jelzi, hogy az intézmény pozícióját a piaci szereplők rosszabbnak ítélik, így érdeke, hogy alacsonyabb értéket jelentsen, ezáltal ,jobb” színben tüntesse fel magát a többi piaci szereplő előtt. Itt az intézmény a piaci szereplők közötti aszimmetrikus információt használhatja fel manipulatívan, hiszen a lehető legtöbb információval a saját pozíciójáról önmaga rendelkezik. A téves jelzéssel lényegében egy rossz mutatókkal rendelkező intézmény a piacról való kiszorulását is megakadályozhatja. Az aszimmetrikus információs helyzet hasonlít Akerlof híres tragacspiacához (Akerlof [1970]). Itt azonban a „rossz” kondícióban lévő intézmények szorulnának ki a piacról. Az aszimmetrikus információ megszüntetésére Spence munkapiaci modelljében javasolja a szignálozást, melynek segítségével felismerhetők a jó munkavállalók (Spence [1973]). Esetünkben azonban az intézmény a kamatjegyzést arra használja, hogy ne lehessen a „rossz” tulajdonságait felismerni. Ez egyfajta inverz problémának is tekinthető.

Tekintsük újra az F intézményt és tegyük fel, hogy piaci zavarok miatt a bankközi források árazása nagyon érzékennyé válhat a forrást felvevő intézmény piaci megítélésére. A minél alacsonyabb müködési költségek elérése érdekében az F intézménynek az a célja, hogy minél olcsóbban jusson piaci forráshoz és a referencia-érték jegyzésével akár a forrásszerzési

\footnotetext{
${ }^{12}$ Bizonyítást lásd 8.9. mellékletben.

${ }^{13}$ Bizonyítást lásd 8.9. mellékletben.

${ }^{14}$ A forint referencia-kamatláb (BUBOR) esetében a definíció szerint az intézmények arról nyilatkoznak, milyen áron tudnak fedezetlen bankközi hitelt kihelyezni, vagyis nem a saját megítélésüket közvetítik.
} 
problémáit is elrejtse. Egyszerüsítésként felteszem, hogy $\mathrm{F}$ mindössze két jegyzés közül választhat. Vagy a valós (V) értéket jelenti, vagy egy jelzésértékü S értéket jelez (szignáloz), ahol $\mathrm{V}>\mathrm{S}$ és $\mathrm{S} \geq \mathrm{L}$, vagyis a többi résztvevő nem kérdőjelezi meg a jegyzés valódiságát.

Feltételezem, hogy S a legalacsonyabb olyan érték, melyről F biztosan tudja, hogy eleme az $[\mathrm{L}, \mathrm{V}]$ intervallumnak. Amennyiben az intézmény $\mathrm{V}-\mathrm{t}$ jelent a müködési költsége $\mathrm{x}$, amennyiben $S-t$, akkor $x-z$, ahol $z \geq 0$. Ekkor F számára $S$ domináns stratégia V-vel szemben, hiszen alacsonyabb működési költség mellett végzi a tevékenységét annál, mintha az $\mathrm{F}$ intézmény igazat mondott volna. A szignál révén az $\mathrm{F}$ intézmény kedvezőbb piaci feltételekkel szembesül, hiszen az alacsonyabb jegyzés révén az F intézmény kedvezőbb piaci feltételekkel szembesül, kifizetése nagyobb lesz, mivel jogosulatlan versenyelőnyhöz jut a referencia-kamat jegyzési szabályainak megsértésével.

A profitabilitási ösztönzőhöz hasonlóan belátható, hogy amennyiben létezne $\mathrm{P}=\mathrm{S}-\varepsilon$ jegyzés is, ahol $\varepsilon \geq 0$ és $\mathrm{P}$ szintén benne van az [L, V] intervallumban, akkor a $\mathrm{P}$ jegyzés választása gyengén dominálná az $\mathrm{S}$ választását, vagyis $\mathrm{F}-n e k$ megérné $\mathrm{P}-\mathrm{t}$ mondani $\mathrm{S}$ helyett. Ha feloldanánk a feltételt, és F ismerné L-t, akkor a fentiekhez hasonlóan belátható, hogy L lenne az optimális választás ${ }^{15}$.

\section{Két ösztönző együttes jelenléte}

A fenti két pontban egy játékelméleti példán is bemutattam a két különböző ösztönző jelenlétét a jegyzési folyamatban. Mindkét ösztönző nagyobb profitot eredményez az aktív kamatjegyző intézmény számára, azonban két különböző csatornán keresztül. Az egyik a kamatjegyző saját kamatpozícióin keletkező többletbevétel, míg a másik az intézmény költségszerkezete (kiadási versus bevételi oldal). Azonban nem szabad elfeledkezni arról a tényröl, hogy a fenti két ösztönző együttesen van jelen.

Ennek vizsgálatához tételezzük fel az alábbiakat. Az F intézmény az adott napon választhat, hogy a $V$ valós értéket jelzi, vagy az $M>V$ értéket jelentve $\gamma$ többletbevételre tesz szert, vagy az $\mathrm{S}<\mathrm{V}$ értéket szignálozva a költségcsökkenésen keresztül $\delta$ többletprofitot realizál. Az S és $\mathrm{M}$ továbbra is eleme az [L, $\mathrm{U}]$ intervallumnak. Feltesszük továbbá, hogy $\mathrm{F}$ tudása szerint az $(S-\varepsilon)$ és $(M+\sigma)$ értékek már nincsenek az $[L, U]$ intervallumban bármekkora is $\varepsilon$ és $\sigma>0$. Könnyen belátható, hogy ekkor a többi kamatjegyző intézmény jegyzésétől függetlenül a

\footnotetext{
${ }^{15}$ Lényegében a függelékbeli 2. állítás megfelelője abban az esetben, mikor a kamatjegyző számára az alacsonyabb referencia-kamatszint kívánatos. Ekkor az állitás bizonyítása analóg módon történik az 1. illetve a 2 . állítás bizonyításában megadott gondolatmenettel. Jelen tanulmány ezen irányok részletes bizonyítására nem tér ki, ugyanakkor ezek bemutatása is a további kutatások elemét képezi.
} 
szignálozás vagy a kamatpozíciókon keresztüli profit manipuláció közül annak a választása előnyösebb F számára, amelyik nagyobb többletprofitot eredményez. Amennyiben $\delta>\gamma$, akkor F szignáloz, ellenkező esetben $F$ intézmény az $M$ stratégiát választja. A valóságban is ez a kérdéskör játszódott le az intézményeknél. Normál ügyletmenet esetén a szignálozásból származó eredmény alacsonyabb volt. A globális válság során a forrásköltségek jelentős növekedésével ez a tendencia megfordult, és a kamatjegyző intézmények egyre gyakrabban választották a szignálozást a kamatpozíciókon keresztüli profitnövelés helyett. Ugyanakkor a két csatornán keresztüli ösztönző bemutatása rendkívül fontos, hiszen a manipulálási ösztönzőt hordozó ügyletek az intézmények különböző müködési területéről származnak és a manipulációval kapcsolatos elemzéseknél mindkét irányra szükséges kitérni.

A fentiek alapján egyszerü játékelméleti példákon is belátható, hogy a LIBOR-szabályzat pontjainak betartása kiemelt jelentőséggel bír. Akár egyetlen pont figyelmen kívül hagyásával az aktív kamatjegyző intézmény számára rendelkezésre áll olyan stratégia, mely dominálja az igazmondást.

\section{Folyamatos manipuláció a Barclays esetében - egyszerüsített megközelítés}

A korábban hivatkozott Haaker és Diehl tanulmányok ${ }^{16}$ kizárólag egyszeri döntéseket vizsgáltak, azonban fontos kiemelni, hogy a valóságban, egy időben hosszan elnyúló, többszöri manipuláció történt. Ennek vizsgálatára egy egyszerüsített modellt alkalmazok, melynek feltételei - egyes esetekben - túlzónak is tünhetnek, ugyanakkor az egyszerübb formulák segítik az eredmények könnyebb értelmezését.

Kiindulásként felteszem, hogy $\left[\mathrm{L}_{\mathrm{i}}, \mathrm{U}_{\mathrm{i}}\right]$ intervallumbeli $\mathrm{M}_{\mathrm{i}}$ választásával ${ }^{17}$ az $\mathrm{F}$ kamatjegyző intézmény a többi kamatjegyző intézmény ,valós” választása ${ }^{18}$ mellett $\alpha_{\mathrm{i}}^{\mathrm{F}} \geq 0$ nagyságú többletprofitot ${ }^{19}$ ér el az i-edik kereskedési napon. Továbbá felteszem, hogy amennyiben $\mathrm{F}$ folyamatosan manipulálja a referencia-kamatlábat, a kezdeti nulláról minden kereskedési nap $\lambda \geq 0$ értékkel nő annak a valószínüsége, hogy az $\mathrm{F}$ jegyzési viselkedése más piaci szereplők számára feltünik, és vele szemben felügyeleti vizsgálat indul. A legelső nap a vizsgálat valószínűsége nulla, mivel minden szereplő tiszta lappal kezdi meg a tevékenységét. Amennyiben vizsgálat indul $\mathrm{F}$ ellen, akkor a manipulatív viselkedésére fény derül, és $\mathrm{B} \geq 0$

\footnotetext{
${ }^{16}$ Haaker [2013] és Diehl [2013]

${ }^{17}$ Vagyis a többi piaci szereplő egyszeri döntés esetén valós értéknek véli a „hamis” jegyzést.

${ }^{18}$ Feltételezem, hogy a többi kamatjegyző intézmény nem manipulál, és a valós referencia értéket jegyzi.

${ }^{19}$ Egyszerüsítésként felteszem, hogy $\alpha_{i}^{F}=\alpha^{F}=\alpha$ minden vizsgált periódusra. A felső index az intézmény specifikusságot mutatja. Mivel a levezetések egy intézményre koncentrálódnak, a könnyebb követhetőség érdekében a felső indexet elhagyom. (Ez utóbbi igaz $\lambda$-ra is.)
} 
összegü bírságot kap. Emellett felteszem, hogy kizárólag csak azon esetben lehet F esetében manipulációra következtetni, ha legalább egymás után kétszer manipulál és F elköteleződik a stratégiák mellett, vagyis a folytonos manipulálás befejezése után kizárólag az igazmondást választja.

Az egyszerüség kedvéért felteszem, hogy a kifizetéseknek nincsen időértéke, vagyis a diszkontkamatláb nulla. Ebben az esetben egyértelmü, hogy $\mathrm{F}$ számára addig éri meg manipulálni, míg az adott kereskedési napon a várható kifizetése pozitív (ha $\mathrm{n}$ jelöli az egymást követő manipulált kereskedési napok számát)

$$
0 \leq \alpha[1-(n-1) \lambda]-(n-1) \lambda B
$$

illetve a manipuláció összes várható többletbevétele meghaladja a bírság B értékét

$$
B \leq \sum_{i=1}^{n} \alpha[1-(i-1) \lambda]-(i-1) \lambda B
$$

Amennyiben a diszkontkamatláb (r) nem nulla, a (3.2)-es egyenlet az alábbi formát öltené

$$
B \leq \sum_{i=1}^{n} \frac{\alpha[1-(i-1) \lambda]-(i-1) \lambda B}{(1+r)^{i-1}}
$$

A (3.2)-t kibontva - alkalmazva a véges számtani sorozat összegképletét - n-re egy másodfokú összefüggést kapunk $\alpha, \lambda$ és B függvényében

$$
0 \leq-\lambda(\alpha+B) n^{2}+[2 \alpha+\lambda(\alpha+B)] n-2 B
$$

Alkalmazva a másodfokú egyenlet megoldó képletét az egymást követő manipulált kereskedési napok számára a következő adódik:

$$
n_{1,2}=\frac{-[2 \alpha+\lambda(\alpha+B)] \pm \sqrt{[2 \alpha+\lambda(\alpha+B)]^{2}-8 \lambda(\alpha+B) B}}{-2 \lambda(\alpha+B)}
$$

Mivel $\alpha, \lambda$ és B nemnegatívak, így a (3.4)-es egyenlet egy konkáv parabolát ír le. Ebből következően, amennyiben az egyenlőtlenségnek létezik megoldása, akkor a lehetséges $n$ értékek az $\left[\mathrm{n}_{1}, \mathrm{n}_{2}\right]$ intervallumban találhatók. Belátható, hogy amennyiben az $\left[\mathrm{n}_{1}, \mathrm{n}_{2}\right]$ és a $[2$, $\infty)$ intervallumok metszete nem üres, akkor F-nek érdemes tartósan manipulálnia a kamatlábat. Ekkor $\mathrm{F}$ azon $\mathrm{n}$ értéket választja, mely mellett a várható többlet bevételét maximalizálja 


$$
\max _{n} \sum_{i=0}^{n} \alpha[1-(i-1) \lambda]-(i-1) \lambda B
$$

Minden más esetben kizárólag az első kereskedési napon manipulál $\mathrm{F}$ intézmény a referenciakamat jegyzése során. Ekkor ugyan a (3.2)-es feltétel nem teljesül, de nulla a manipulálás lelepleződésének kockázata.

A fenti feltételrendszerben $\alpha$ egy intézmény specifikus paraméter, melynek értéke aktív kamatjegyző intézményenként eltérő lehet. Sem a definícióért felelős szakmai szervezeteknek, sem a felügyelő hatóságoknak nincsen befolyása $\alpha$ értékére. A bírság $\mathrm{B}$ mértékének megállapítása felügyeleti hatókör. A LIBOR botrány körüli tapasztalatok is azt mutatják, hogy a hatóságok a történelem során még nem tapasztalt mértékü bírságokat szabtak ki. Azonban a LIBOR manipulálás esetén az évek során felhalmozódott többlet profitokról nincsen információnk, így a bírságok mértékével nem tudjuk összevetni. A jogszabályi környezet általában kellően rugalmas gigantikus bírságok kiszabására is, ám a gyakorlatban a bírságok szintje felülről korlátosnak tekinthetö ${ }^{20}$. Ha feltételezzük, hogy a felügyeleti hatóság a $\mathrm{B}$ bírságot kellően nagy értéken állapítja meg, akkor a folyamatos manipuláció nem kifizetődő. Azonban nem hagyható figyelmen kívül, hogy még ezen egyszerü modellünkben sem képes egy gigantikus bírság megakadályozni a manipuláció bekövetkeztét. Mivel az intézmény számára mindenképpen megéri a legelső lejátszás során az Mi értéket jelenteni, egy megfelelően nagy B bírság csak a további tartós manipulációt akadályozza meg.

A fenti összefüggések további vizsgálatához felteszem, hogy a B bírság az $\alpha$ többlet profit kszorosa $(\mathrm{k}>0)$, vagyis $\mathrm{B}=\mathrm{k} \alpha$. Emellett legyen $\alpha>0$, vagyis az $\mathrm{F}$ intézmény legyen képes olyan manipulatív jegyzést adni, melynek révén a referencia kamat értéke a számára kedvező irányban elmozdul. Ekkor (3.1) az alábbi formára hozható:

$$
n \leq 1+\frac{1}{\lambda(k+1)}
$$

A (3.7) egyenlőtlenségből látható, hogy a folyamatos manipuláció abban az esetben kerülhető el, ha $\lambda(1+\mathrm{k})$ értéke meghaladja az 1-et, vagyis ehhez vagy a lelepleződés valószínüségét vagy a bírság mértékét kell növelni. Tekintsük most a (3.5) formulát. A másodfokú egyenletnek, akkor lesznek valós megoldásai, ha a diszkriminánsa nem negatív, vagyis

\footnotetext{
${ }^{20}$ Egyes országokban a kiszabható bírságok felső határa törvényben rögzített, és bírság kiszabásánál a hatóságok a pénzügyi rendszer stabilitását is figyelembe veszik. Nem éri meg olyan mértékü bírság kiszabása, mely megroppanthatja a pénzügyi rendszert, hiszen az így keletkező társadalmi károk a manipuláció okozta károknál is jóval nagyobbak lehetnek.
} 


$$
0 \leq[2 \alpha+\lambda(\alpha+B)]^{2}-8 \lambda(\alpha+B) B
$$

Amennyiben $\mathrm{B}=\mathrm{k} \alpha$, a következő adódik $\alpha^{2}$-tel való egyszerüsítés után

$$
0 \leq[2+\lambda(1+k)]^{2}-8 k \lambda(1+k)
$$

Legyen $\mathrm{x}=\lambda(1+\mathrm{k})$, ekkor (3.9) az alábbi formába írható

$$
0 \leq[2+x]^{2}-8 k x
$$

vagyis

$$
0 \leq x^{2}+(4-8 k) x+4
$$

Könnyen belátható, hogy mivel a k szigorúan pozitív, a (3.11) alatti egyenlőtlenségnek csak abban az esetben nincs megoldása, ha $\mathrm{k}>1$. Minden más esetben (3.11) az alábbi alakra írható:

$$
0 \leq(x \pm a)^{2}+b
$$

ahol a és $b \geq 0$. Ezen feltételek mellett (3.12) nyilvánvalóan teljesül, vagyis a (3.9)-es diszkrimináns nem negatív. A k > 1 esetben (3.11) az alábbi általános formába írható fel (c, d $>0)$ :

$$
0 \leq(x-c)^{2}-d
$$

Amennyiben $\mathrm{x}=\mathrm{c}$ lenne, akkor (3.13)-nak nem lenne megoldása. Ebben az esetben $\mathrm{x}=$ $\lambda(1+\mathrm{k})$ és $\mathrm{c}=4 \mathrm{k}-2$ egyenletekből és a $\mathrm{k}>1$ feltételből $\lambda>1$ adódik, ami nem lehetséges, mivel $\lambda$ valószínűséget jelöl. Vagyis nem adható meg egyértelműen olyan univerzális $\lambda$ érték (értéktartomány), amely bármely $\mathrm{k}$ esetén biztosítaná a folyamatos manipuláció elkerülését. A $\lambda$ és $\mathrm{k}$ összefüggnek, a bírság nagysága minden esetben kihat az $\mathrm{F}$ intézmény által még tolerálandó lelepleződési valószínüségre.

A szakmai szabályozó és a felügyeleti hatóság megfelelő külső és belső kontrollrendszerekkel azonban képes a $\lambda$ értéket és közvetetten az Ui és $\mathrm{Li}$ értékeket befolyásolni. A $\lambda$ növekedésével egy alacsonyabb $\mathrm{B}$ bírság esetén is elvetendővé válik a tartós manipuláció $\mathrm{F}$ számára. A szigorú kontrollfolyamatokkal ráadásul Ui és Li érték is közelíthető egymáshoz, így az F intézménynek sokkal kisebb területe marad a manipulációra. Sőt, ha figyelembe vesszük az additív hatásokat, az [Li, Ui] intervallum olyan szük lehet, hogy már nem éri meg manipulálni az intézménynek.

Azonban nem szabad figyelmen kívül hagyni, hogy a felügyeleti hatóságnak a valóságban nincs pontos információja az $\alpha$ többletprofit értékéről, mivel még a LIBOR manipulálás 
bebizonyosodása után sem vállalkozott senki arra, hogy megmondja, mi lett volna a helyes referencia érték, mivel igazmondás esetén sem egy adott képlet alapján adódik az intézmény jegyzése. Mindazonáltal a k valós értékére következtethetünk. A 2014-es EBA stressz teszt alapján a Barclays 2013-as becsült nettó kereskedési bevétele 7836 millió ${ }^{21}$ euró volt. A bank összesen az amerikai és az angol felügyeleti hatóságoktól 360 millió amerikai dollár és 59,5 millió font értékü bírságot kapott, ami a 2013.12.31-i MNB középárfolyamok alapján megközelítőleg 333 millió eurónak fel meg. Amennyiben feltételezzük, hogy a Barclays a kereskedési profitjának felét manipulációval érte el a kereskedési napokon ${ }^{22}$ egyenletesen elosztva, akkor a Barclays adataival számolva k értéke:

$$
k_{\text {Barclays }}=333 /\left(\frac{0,5 * 7836}{250}\right)=21,25
$$

Ezt az értéket (3.9)-be helyettesítve a másodfokú egyenlet megoldó képlete alapján $\lambda$-ra 0,00108-as érték ${ }^{23}$ adódik, vagyis az egymást követő második kereskedési napon mindösszesen $0,11 \%$ a lebukás valószínüsége. Az optimális manipulációra (3.7) alapján

$$
n \leq 1+\frac{1}{0,00108 *(21,25+1)}=42,6
$$

kereskedési nap adódik, vagyis 42 kereskedési napon keresztül érné meg a manipuláció. Egyszerü behelyettesítéssel belátható, hogy a 42-dik kereskedési napon a (3.1)-es feltétel is teljesül. Fontos hangsúlyozni, hogy ez egy nagyon leegyszerüsített számítás, azonban érdemes belegondolni, hogy a valóságban hogyan alakulhattak ezen értékek, ha a 2011-ben indult vizsgálatok során 2006-os manipulációra is fény derült, ugyanakkor a jegyzésben megtalálható manipulációra utaló jelek még a 2008-2010 közötti időszakban sem ösztönözték a szabályozó hatóságot a cselekvésre.

A fenti leegyszerüsített modellel rávilágítottam a LIBOR definícióban rejlő manipulálási ösztönzőkre, melyek több csatornán keresztül is „hamis” jegyzés megadására sarkallják az intézményeket. Ezen ösztönzők részben a forint referencia-kamatláb definíciójában is megtalálhatók (bővebben például Fliszár [2015]).

A részletesen leírt ismételt döntést vizsgáló modell segítségével a jegyzési folyamat egy további gyenge pontjára mutattam rá. Ez pedig a külső és belső kontrollfolyamatok

\footnotetext{
${ }^{21}$ Forrás: EBA http://www.eba.europa.eu/documents/10180/851773/UK_G5GSEF7VJP5I7OUK5573.pdf ${ }^{22}$ Az év során 250 kereskedési napot feltételezve.

${ }^{23}$ A megoldó képletből két valós gyök adódik. A másik megoldás nagyobb mint egy, így esetünkben nem értelmezhető, mivel egy valószínűségnek a kritikus értékét keressük.
} 
megfelelősége. Jean Tirole több tanulmányában is foglalkozott szabályozási kérdésekkel. Az általam felvázolt modell nagyfokú hasonlóságot mutat a Tirole által alkalmazott modellekkel (lásd bővebben például Tirole [2006], Bayer [2012], Csóka et al. [2013] vagy Berlinger et al. [2015]). A referencia-kamatok jegyzésénél több szempontból is megjelenik az információs aszimmetria. A piaci szereplőket megvezetheti a kamatjegyző mivel azok nincsenek pontosan tisztában a kamatjegyző piaci kondíciójával, így egy téves szignált tud küldeni. Ugyanakkor a szabályozó hatóságok sincsenek minden információ birtokában, és nekik érdekük, hogy a piacon egyik fajta manipuláció se következzen be (profitabilitás, szignálozás). A megfelelő kontroll és monitoring folyamatok segíthetnek a szereplőknek az aszimmetrikus információs helyzet feloldására. Ezt szemlélteti részletesen az ismétléses modell is, melyben a (3.1) egyenletre, mint ösztönzési, a (3.2) egyenletre, mint részvételi korlátra tekinthetünk.

\subsection{Korai jelek a sajtóban}

A LIBOR-ral kapcsolatos problémákra utaló jelekkel a sajtó már jóval a 2012-ben kitört botrány előtt is foglalkozott. Carrick Mollenkamp több cikket (Mollenkamp [2008] és Mollenkamp - Enrich [2011]) is írt a Wall Street Journal (WSJ) hasábjain, amelyekben a LIBOR jegyzésének hitelességével kapcsolatos kétségeket vetett fel.

2008-as cikkében a LIBOR definíciójából származó kockázatokra hívja fel a figyelmet, vagyis arra, hogy a jegyzést végző bankoknak érdekükben állhat a valós értékektől eltérő kamatszintek jegyzése, hiszen így a róluk kialakult piaci képet befolyásolhatják, adott esetben a kedvezőtlen likviditási szintjükre utaló jeleket is eltakarhatják. A cikk a fenti probléma ismertetése mellett részletesen kitért a LIBOR definíciójára, a londoni referencia-kamatláb világpiaci szerepére (a bankközi müveletektől egészen a lakossági hitelekig) és a lehetséges alternatív benchmark értékekre is.

Mollenkamp és Enrich 2011-ben közösen publikált cikkükben már konkrétan manipulációról beszélnek, mellyel kapcsolatos vizsgálatokat már a felügyeleti hatóságok is megindították. A nagybankok közül a svájci UBS-t említik, amely pénzintézet a 2012-es éves riportjában már beszámolt a vizsgálatról. A cikk szerzői megállapítják, hogy kevés a valószínűsége annak, hogy a LIBOR körül feltárt gondokat a szabályozók egyszerűen téves jegyzéseknek fogják minősíteni. Ennek alátámasztására Snider és Youle 2010-es (Snider - Youle [2010]) tanulmányára is hivatkoznak, amelynek a szerzői arra keresték a választ, hogy a LIBOR 
mennyire képes a definícióbeli szerepének megfelelni, vagyis a jegyző bankok tényleg azt a kamatszintet adják-e meg, amelyen a bankközi piacon fedezetlen forráshoz jutnának.

Szakmai folyóiratban a manipuláció szó használata már 2008-ban is felbukkant, bár Mollenkamp a sokkal nagyobb olvasóréteghez tartozó WSJ hasábjain ekkor még nem merte ezt a kifejezést használni. Abrantes-Metz és társai a 2008 augusztusában megjelent tanulmányuk címében már felteszik a kérdést: LIBOR manipuláció? (Abrantes-Metz et al. [2008]). A szerzők az összegzésükben kiemelik, hogy számos jel - például a CDS szpredek ${ }^{24}$ és a LIBOR-értékek nem eltérő mozgása - utal versenyellenes, manipulatív viselkedésre, de kézzel fogható bizonyítékokkal nem rendelkeznek a manipuláció alátámasztására. Konklúziójukban ezért további vizsgálatok szükségességét fogalmazzák meg.

\subsection{A felügyelő hatóságok vizsgálatainak eredményei}

A sajtóban megjelenő jelek a hatóságok figyelmét is ráirányították a LIBOR esetében tapasztalható problémákra. 2008-ban a Bank of England kormányzója, Mervyn King az Egyesült Királyság parlamentjében már sötét képet festett a LIBOR-ról. A londoni parlament Alsóházában a Treasury meghallgatáson King többek közt az alábbi kijelentést tette a LIBOR-t feszegető kérdésekre:

„I think it is convenient, very often, for people to justify what they do for other reasons, in terms of Libor, but it is not a rate at which anyone is actually borrowing." (House of Commons [2008])

Vagyis a LIBOR 2008-ban már a Bank of England kormányzója szerint sem tudta teljes körüen betölteni a szerepét (bővebben lásd a 3.4-es fejezetet), hiszen egy olyan rátát takart melyen egy piaci szereplő sem volna hajlandó hitelt nyújtani.

Ugyanakkor felügyeleti intézkedések ekkor még nem történtek, ami különösen annak fényében meglepő, hogy mind a Bank of England, mind a FED vezetői is tisztában voltak a LIBOR körüli problémákkal. 2012-ben ezt a mulasztást a Guardian hasábjain Jill Treanor és Dominic Rusche is felvetette (Treanor-Rusche [2012]). A szerzők a cikkükben kiemelik, hogy 2008 folyamán a jegybankok vezetői már egyeztettek a kamatjegyzés reformjáról annak apropóján, hogy egy Barclays alkalmazott a Bear Stearns megmentése kapcsán a túl alacsony jegyzések miatt megkongatta a vészharangot (Mackenzie-Nasiripour-Jenkins [2012]). Bár a

\footnotetext{
${ }^{24}$ CDS szpred vagy CDS díj: azon kifizetések sorozata, melyet a CDS vásárlója a CDS kibocsátó számára fizet a swap időtartama során.
} 
megbeszélésről készült emlékeztető, mégsem történtek lépések a LIBOR megerősítése érdekében.

Azonban az idő előrehaladtával a szabályozók számára is világossá vált, hogy itt nem egyszerü módszertani, definíciós problémával állnak szemben, hanem sokkal súlyosabb kérdés - a manipuláció - is felmerült, aminek következtében egy egyszerü reform nem oldaná meg a problémát, hanem a jelenlegi jegyzési folyamat mélyére kell ásni és feltárni a hiányosságokat, valamint azonosítani a tisztességtelen piaci szereplőket. Ennek céljából 2011ben vizsgálatok indultak a LIBOR-jegyzés folyamatáról. Az amerikai felügyeleti hatóságok a Bank of America, a Citi és az UBS esetén indítottak vizsgálatokat, ez állt 2011 márciusában a Wall Street Journal hasábjain (Enrich - Mollenkamp - Eaglesham [2011]). Ezzel egyidőben Londonban a The Telegraph hasábjain már kemény hangvételü cikk jelent meg a Barclays szerepével kapcsolatosan (Dunkley - Wilson [2011]), mely rámutat, hogy a Barclays-ra hatalmas nyomás nehezedik, hogy a LIBOR jegyzésben/manipulálásban betöltött szerepét tisztázza.

\subsection{A manipuláció bebizonyosodása}

2012-ben, mikor az első felügyeleti vizsgálatok eredményei kezdtek beérkezni, nyilvánvalóvá vált, hogy itt nem pusztán definíciós vagy módszertani problémáról, hanem manipulálásról van szó, és a botrány elkerülhetetlen.

Mollenkamp 2012. február 28-án, a Reuters hasábjain arról tudósított, hogy a LIBORvizsgálatok büncselekmény gyanúját vetik fel és az Egyesült Államokban az Igazságügyi Minisztérium (Justice Department), valamint Japán, Kanada és az Egyesült Királyság igazságügyi szervezeteit is bevonták a vizsgálatokba (Mollenkamp [2012]). A vizsgálatok rávilágítottak arra, hogy a jegyzésben résztvevő kereskedők megsértették a referenciakamatláb kialakításánál a belső függetlenséget, mivel számos bizonyíték utalt arra, hogy a jegyzés elött az adott intézményeknél a bankok más területeivel kommunikáció zajlott, amely kitért a referencia-kamatláb kívánt elmozdulási irányára is, és ezen kívánalmak a referenciaérték tényleges jegyzésében is megjelentek. Vagyis a piac számára megjelenített LIBORértékek nem kizárólag a definícióban megfogalmazott információkon alapultak, hanem erőteljesen tartalmazták a jegyzést végző intézmények egyedi többlet-,tudását” is.

Ez utóbbit erősítette meg a Reuters hasábjain 2012. március 30-án a Royal Bank of Scotland (RBS) volt kereskedője, Tan Chi Min (Armstrong [2012]) is. Tan - aki korábban az RBS 
delta trading treasury területének a vezetője volt - bevallotta, hogy Brevan Howard, az egyik legnagyobb európai hedge fund kezelője arra kérte az RBS-t, hogy mozdítsa el a LIBORértéket a számukra kedvező irányba. Tan szingapúri bíróságon tett vallomása alapján az RBS Howard kérésének feltételek nélkül eleget is tett. Emellett azt is kiemelte, hogy ez nem egyedüli eset volt. Bevett gyakorlatnak számított, hogy a bank vezető beosztású tisztségviselői kérték a jegyzést végző kereskedőket a LIBOR-jegyzések valamilyen irányú elmozdítására. Tan a fentieken túl a vallomásában kitért arra a tényre, hogy a botrány kirobbanása után az RBS úgy próbálta magát menteni, hogy a dolgozóiból csinált bűnbakot, és egyedi döntésekként állította be a napvilágra került eseteket. Azonban az érintett dolgozók kiemelt jelentőségü beosztása miatt ez az ötlet eredménytelennek bizonyult, és inkább csak az intézmény fölé gyülekező sötét fellegeket szaporította.

Pár hónappal Tan Chi Min lényegre törő vallomástétele után a felügyeleti hatóságok gigantikus méretü bírságokról adtak ki közleményeket. Elsőként 2012 nyarán a Barclays bankra sújtott le a szabályozók keze. 2012. június 27-én az amerikai Commodity Futures Trading Commission (CFTC [2012a]) és a United States Departement of Justice (USDJ [2012a]) összesen 360 millió (200, illetve 160 millió) dollárnyi bírságot szabott ki a Barclaysra. Emellett az angol pénzügyi felügyelet (FSA [2012a]) is kirótt 59,5 millió fontos bírságot a referencia-kamatlábak (LIBOR és EURIBOR ${ }^{25}$ ) jegyzésében feltárt súlyos hiányosságok miatt.

Az USDJ közleményéből kiderül, hogy a Barclays esetében legalább 2005-re nyúlik vissza a manipuláció gyakorlata. Ennek az angol bank esetében alapvetően két oka volt:

- a jegyzésnél a kereskedők figyelembe vették a saját portfóliójukban lévő pozíciójukat, és a ráta mozgatásával az eredményességüket segítették elő;

- a 2007-ben kezdődött globális pénzpiaci válság alatt a bank szándékosan jelentett a valósnál alacsonyabb rátákat, mivel így a többi pénzpiaci szereplő számára jobb kondícióban tüntette fel magát.

A jelentések rávilágítottak, hogy a kialakult jegyzési folyamatban súlyos hiányosságok voltak. A beépített belső és külső ellenörzési mechanizmusok nem voltak elégségesek a jegyzések teljes körü transzparenciájának biztosítására, és nem tudták megakadályozni az intézményi érdekek okozta torzulásokat a jegyzett értékekben.

\footnotetext{
${ }^{25}$ EURIBOR - Euro Interbank Offered Rate. Az európai bankok részvételével kialakított irányadó bankközi kamatláb. Elöször 1999. január 1-én az euró bevezetésével együtt került jegyzésre több nemzeti irányadó kamatláb - köztük a PIBOR (Franciaország) és a FIBOR (Németország) - utódjaként. (További információ: http://www.euribor-rates.eu/what-is-euribor.asp)
} 
A szabályozói jelentések kihatottak az érintett bankok vezető beosztású tisztségviselőire is. 2012. július 2-án a Barclays elnöke, Marcus Agius lemondott a posztjáról, akit egy nappal később július 3-án a bank vezérigazgatója (Chief Executive Officer - CEO), Bob Diamond és a müködésért felelős vezetője (Chief Operating Officer), Jerry del Missier is követett. A botrány kirobbanásának következményeként két nap alatt a Barclays három vezető beosztású tisztségviselöje is távozott (BBC [2012a]). A lemondásokban nagy szerepe volt annak a ténynek is, hogy a botrány nyilvánosságra kerülése utána a Barclays részvények árfolyama egy nap alatt több mint 15\%-kal esett. A vezetök a távozásukkal a bankon lévő reputációs nyomást is enyhítették, bár ellenkező esetben valószínüleg a távozásukat a szabályozó hatóságok is kikényszerítették volna. (Az RBS esetén a későbbiekben ez be is következett.)

A július eleji események azonban elöre jelezték, hogy a bírságok nem állnak meg a Barclays küszöbénél. 2012. július 1-én, egy nappal a Barclays vezér lemondása előtt, a BBC arról tudósított, hogy az RBS négy kereskedőjét elbocsátotta a LIBOR-botrányban való érintettségre hivatkozva (BBC [2012b]).

Mindezek ellenére a következő megbírságolt bank a svájci UBS volt. 2012. december 19-én az amerikai hatóságok 700 millió illetve 500 millió dolláros bírságot szabtak ki a bankra (CFTC [2012b]) és USDJ [2012b]). Ezzel egy időben az angol és a svájci felügyelet további 160 millió angol fontra illetve 59 millió svájci frankra büntette a UBS-t (FSA [2012b]) és FINMA [2012]). Kiemelendő, hogy a CFTC a közleménnyel együtt egy, a LIBOR manipulálást bizonyító dokumentumot is nyilvánosságra hozott, mely négy oldal terjedelemben idéz példákat a UBS kereskedőinek az írásbeli kommunikációjából. A szabályozók a 2005-2010 közötti időszakban több mint 2000 esetet találtak, mikor a LIBOR adott irányú elmozdítására kérés érkezett. A bemutatott példák alapján előfordult, hogy a kereskedők a saját profitabilitásuk növelése érdekében cselekedtek, de olyan esetek is előfordultak, mikor kifejezetten a UBS központi treasury-je utasított konkrét jegyzésre. Egy ilyen példa 2007. augusztus 9-ről az, amikor a központi treasury eszköz-forrás menedzsere az alábbi utasítást adta:

„It is highly advisable to err on the low side with fixings for the time being to protect our franchise in these sensitive markets. Fixing risk and PNL thereof is secondary priority for now." (CFTC [2012c])

Az utasításában a bank központi területe egyértelműen kérte, hogy a jegyzés alacsony érték legyen, és aznap kerüljön bele az alulról lenyesett értékek közé. Ezáltal a valósnál stabilabb képet próbáltak közvetíteni a bankról a piac számára. 
2013. február 6-án az angol felügyelet az RBS 87,5 millió fontos megbírságolásáról adott ki közleményt (FSA [2013]). A dokumentum szerint az RBS a japán yen, a US dollár és a svájci frank LIBOR jegyzésénél a definícióval ellentétesen figyelembe vette a saját derivatív és pénz-piaci (money market) kereskedési pozícióit. A kereskedői a LIBOR meghatározásánál összejátszottak a többi jegyzésben résztvevő bank kereskedőivel és a bankközi piaci brókerekkel. Mindazonáltal a bírságot követően a bankcsoport felelős vezetője, Stephen Hester a helyén maradt, csak a bónuszait vonták meg. Ez a szakmai sajtót is meglepte, egyes cikkekben menekülő művésznek is elnevezték (Fraser [2013]). Hester távozását csak jelentős szabályozói nyomással, 2013 nyarán sikerült elérni.

A vizsgálatok tovább folytatódtak, és 2013. szeptember 25-én ismét újabb szereplöre vetült a LIBOR manipulálásának árnyéka. Az angliai székhelyü ICAP-ot az amerikai hatóságok 65 millió dollárra büntették (CFTC [2013]). A CFTC a UBS esetéhez hasonlóan, az ICAP közlemény mellékletekében szintén nyilvánosságra hozott egy ötoldalas dokumentumot, melyben példákat sorolnak fel a LIBOR eltérítésére irányuló intézményi belső kommunikációból.

Azonban a bírságok sora tovább folytatódott. 2013. december 4-én az Európai Bizottság közleményt adott ki, melyben megállapítja, hogy a vezető intézmények kartellt müködtettek a pénzpiaci derivatívák piacán, és összesen 1,71 milliárd euró bírság került kiszabásra. A 2011ben megindult vizsgálat megállapította, hogy az euró kamatderivatívák piacán 2005 és 2008 között müködött kartell a Barclays, a Deutsche Bank, az RBS és a Société Générale részvételével. A kartell müködése jelentősen kihatott az EURIBOR kamatlábakra, mivel a kereskedők a jegyzésben együttmüködve figyelembe vették a kereskedési pozícióikat és az árazási stratégiájukat is, mely szemlélet ellentétes volt az EURIBOR definíciójával. A Bizottság továbbá megállapította, hogy 2007 és 2010 között kartell müködött a japán yen kamatderivatívák piacán is. A kartellben résztvevő intézmények (UBS, RBS, Deutsche Bank, Citigroup és JPMorgan) több alkalommal egyeztetéseket folytattak a yen LIBOR kívánatos szintjéről (Európai Bizottság [2013]). ${ }^{26}$

2014. július 28-án a Lloyds került a figyelem középpontjába. A bankcsoportot a LIBOR manipulálása miatt az amerikai hatóságok 105 millió dollárra (CFTC [2014]), az angol hatóságok pedig 105 millió angol fontra (FCA [2014]) bírságolták. A csoport a reputációs veszteségek minimalizálása érdekében lépéseket indított. 2014. szeptember 29-én a BBC arról

\footnotetext{
${ }^{26}$ Bár a referencia-értékek jegyzésében nem vett részt, a kartellben való érintettsége miatt az RP Martin brókercég is a megbírságolt vállalatok közé került.
} 
tudósított, hogy a Lloyds nyolc munkavállalóját elbocsájtotta a manipulációban való érintettség miatt. A csoport elnöke, Lord Blackwell a cselekedetüket teljességgel elfogadhatatlannak minősítette (BBC [2014]).

Ez utóbbi fejleményből is látható, hogy a vizsgálatok még egyáltalán nem értek véget, és a mai napig is tartanak. Nem zárható ki, hogy még lesznek további intézmények, melyek súlyos bírságra számíthatnak. Azonban már 2012-ben a Barclays ügy kirobbanásával nyilvánvalóvá vált a szabályozók és a piac számára is, hogy a referencia-kamatlábak területén sürgős változtatásokra van szükség. A folyamatok vizsgálatára irányuló főbb szabályozói dokumentumokat és a bennük rejlő megállapításokat foglalja össze a következő fejezet.

\subsection{Szabályozó hatóságok reakciói}

A londoni referencia-kamatlábak Barclays általi manipulálásának ügye igen komoly vihart kavart, megingatta a LIBOR-ba, sőt a City-be vetett bizalmat. A botrány - mint az előző fejezetben említésre is került - 2012. július 2-án Marcus Agiusnak, a Barclays bankcsoport elnökének, július 3-án pedig Bob Diamondnak, a cég vezérigazgatójának a lemondásához vezetett. Emellett a botrány kedvezötlenül érintette a Barclays üzletmenetét is, aminek következtében két nagy hitelminősítő, a Moody’s és az S\&P is rontott a bankcsoport besorolási osztályzatainak kilátásain. A tőzsdén a Barclays részvényeinek árfolyama 2012. május-július időszakban mintegy 26\%-ot esett. Nyilvánvalóvá vált, hogy a bírságokon túl az egész jegyzési folyamatot érintő szabályozó változásokra van szükség.

\subsubsection{A referencia-kamatlábak Barclays általi manipulálásának vizsgálata}

Az angol pénzügyi felügyeleti hatóság, a Financial Services Authority (FSA [2012c]) és az amerikai Commodity Futures Trading Commission (CFTC [2012]) egy időben, 2012. június 27-én jelentette meg a Barclays-nál lefolytatott, a LIBOR és az EURIBOR (Euro Interbank Offered Rate) kamatlábak különböző devizákra (de kiemelten az amerikai dollárra) és különböző lejáratokra vonatkozó napi jegyzések manipulálására vonatkozó vizsgálatáról szóló jelentését.

A két jelentés közös megállapítása, hogy az alapvető probléma a napi jegyzések nem megfelelő kialakítása volt, ugyanis a jegyzéseknek az adott bankközi piacokon a fedezetlen források hitelfelvételi költségeit kellene tükröznie.

A vizsgálatok megállapították: 
- 2005. január és 2008. július között a Barclays nem megfelelően járt el, amikor a jegyzések kialakításánál figyelembe vette a cég derivatíva-kereskedőinek kéréseit (ugyanis a LIBOR- és EURIBOR-szabályzatok nem engedték meg ezen üzleti szempontok figyelembe vételét);

- 2006. február és 2007. október között a Barclays számos alkalommal befolyásolta más bankok EURIBOR-ra vonatkozó jegyzéseit.

Mindkét esetben felmerült a referencia-kamatlábak manipulálásának megtörténte, különösen akkor, amikor a Barclays más bankokkal egyetértésben cselekedett.

2007. szeptember és 2009. május között a Barclays - a reputációs kockázatok erősödése következtében - több alkalommal úgy határozta meg LIBOR-jegyzését, hogy figyelembe vette azokat az aggodalmakat, amelyet a negatív média bejelentés keltett, mely szerint a Barclays LIBOR jegyzései rendre magasabbak, mint a többi banké, és ez szakértők szerint azt mutatja, hogy a Barclays a többi bankhoz képest drágábban jut forráshoz.

$\mathrm{Az}$ angol FSA jelentése szerint a fentieken túl a Barclays nem rendelkezett megfelelő kockázatkezelési rendszerekkel és hatékony kontroll folyamatokkal a referenciakamatlábjegyzéssel kapcsolatos folyamatok tekintetében. Emellett „megfelelőségi” hibák (compliance failures) is felmerültek, amikor a Barclays nem kellő körültekintéssel és gondossággal végezte a LIBOR jegyzését.

Az FSA elvi alapú (principle based) döntést hozott. A vizsgálat megállapította, hogy a Barclays megsértette az FSA iránymutatásában (FSA [2014]) meghirdetett üzleti elvek (Principles for Businesses) közül az alábbiakat:

- az intézmény köteles üzleti tevékenységét kellő hozzáértéssel, körültekintéssel és gondossággal folytatni (Principle 2);

- az intézmény köteles a tőle elvárható gondossággal - felelősen és hatékonyan - a müködését szervezni, és megfelelő szintű kockázatkezelési rendszerek alkalmazásával monitorozni (Principle 3);

- az intézménynek be kell tartania a piaci magatartásra vonatkozó megfelelő normákat (Principle 5).

Az FSA eredetileg 85 millió angol fontra büntette volna a Barclays-t, de tekintettel a vizsgálat során mutatott rendkívül jó együttmüködésére, 59,5 millió fontra mérsékelte a „megfelelö és arányos" pénzbüntetést. 
A CFTC jelentése nagyrészt egybevág az FSA megállapításaival. Ezeken túl megjegyzi, hogy a Barclays nem a Brit Bankszövetség definíciójának és kritériumainak megfelelően végezte a referencia-kamatok jegyzését, hanem félrevezető, hamis értékeket rögzített. A jegyzést végzők megfelelő szintü napi felügyeletének, valamint a kommunikáció időszakos felülvizsgálatának fel kellett volna tárni a helytelen jegyzési gyakorlatot. A CTFC jelentésében megállapítja, hogy a nyilvánosságra került helytelen jegyzések elkövetését illetően a Barclays felelős az alkalmazottjaiként eljáró kereskedők, menedzserek, jegyzéseket benyújtó munkatársak cselekedetei, mulasztásai és hibái miatt.

A CTFC határozata az alábbiakat tartalmazta:

- a Barclays számára 200 millió amerikai dollár bírságot állapított meg;

- felszólította a Barclays-t

○ a további szabálysértéstől való elállásra;

○ a referencia-kamatláb jegyzés megbízhatóságának és integritásának biztosítására;

○ a megbízható referencia-kamatláb kialakítása érdekében hatékony módszerek és folyamatok beazonosítására, megalkotására és támogatására;

- meghatározta azokat a tényezőket, amelyeket a referencia-kamatláb jegyzésekor figyelembe kell venni;

- elöírta, hogy egy arra kijelölt személynek naponta át kell tekintenie a jegyzés folyamatát.

A felsoroltakon túl a Barclays-nek fel kell állítania egy monitoring rendszert a jegyzés folyamatának ellenőrzésére. Ehhez 60 napon belül ki kell alakítani a megfelelő politikákat, eljárásrendeket, kontroll-funkciókat valamint képzési programokat kell kialakítania a jegyzésben érintett összes alkalmazott számára.

\subsubsection{FSA: The Wheatley Review of $\mathrm{LIBOR}^{27}$}

Az Egyesült Királyság pénzügyminisztere megbízást adott Martin Wheatley-nek, az FSA Consumer and Markets Business Unit ügyvezető igazgatójának, hogy készítsen jelentést azt követően, hogy olyan értesülések kerültek nyilvánosságra, melyek szerint évtizedek óta megkísérelték manipulálni a LIBOR-t és EURIBOR-t.

\footnotetext{
${ }^{27}$ FSA [2012d]
} 
A 2012. szeptember 28-án publikált jelentés - The Wheatley Review - fókuszában a következő kérdések álltak:

- a LIBOR-jegyzés folyamatának reformja;

- a LIBOR-jegyzés manipulálása elleni szankciók, a szankciók hatóköre és ennek következtében a további visszaélések megakadályozása;

- annak felderítése, hogy a LIBOR-fixing vizsgálat során feltárt hibáknak van-e következménye más globális benchmarkokra.

A Wheatley-jelentés megállapította, hogy a LIBOR-jegyzés múltbeli folyamata több olyan elemet is tartalmazott, amely a LIBOR hitelességét megtépázta:

- A LIBOR-nak a fedezetlen bankközi forrásköltségeket kellett volna megjelenítenie, ugyanakkor a válság következtében ez a piaci szegmens jelentősen visszaesett (sőt egyes devizák esetén ki is ürült), így a jegyzés során jelentett értékek sokkal inkább szakértői megítélésen, mint valós tranzakciós adatokon alapultak.

- Az egyedi, egyes intézmények által jelentett kamatláb értékek valódisága nehezen ellenőrizhető, mivel a fedezetlen bankközi piacon illikviditási problémák léptek fel, és ennek következtében a benchmark alapjául szolgáló tranzakciók egyre kevésbé lettek relevánsak a bankok forráshoz jutásában. Ez a megállapítás kiemelten érvényes az alacsony kereskedési volumenű devizák és lejáratok esetében.

- A LIBOR jegyzésében alkalmazott devizapanelek ${ }^{28}$ túl kicsik voltak. A legnagyobb (amerikai dollár) panel is csak 18 bankot tartalmazott. A panelekben való részvétel önkéntes. A fentiek együttesen hozzájárulnak, hogy akár kisszámú bank összejátszása is manipulációhoz vezethet a jegyzésben, így a felhasználók nagy körére lehet hatással a bankok egy kis csoportja.

- Az intézmények és az intézményi munkatársak LIBOR jegyzéseinél több ösztönző is van a manipulálásra: az általuk képviselt intézmény hitelképességének jelzése (a jelentett értékkel egy szignált küldenek a piac felé), vagy a saját kereskedési pozícióik javítása (nagyobb profit reményében). A jelzési ösztönzőt tovább erősítette, hogy a jegyzések napi szinten publikálásra kerültek.

- A LIBOR jegyzésére gyenge ellenőrzési mechanizmusok mellett került sor. Az ellenőrzés hiánya mind intézményi (internal), mind a fixing folyamat átfogó szintjén

\footnotetext{
${ }^{28}$ A panel elnevezés miatt a jegyzésben résztvevő intézményekre sok helyen panelbankként utalnak. A dolgozat további részeiben a két fogalmat egyenértékünek tekintem.
} 
megjelenik. Ennek következtében erősebb felügyelésre, nagyobb függetlenségre és transzparenciára lenne szükség.

- A LIBOR jegyzések során jelentett adatok összerendezése, ellenőrzése és jóváhagyása egy külső cég, a Thomson Reuters feladata felelőssége volt. A fixinget végző intézmények nem voltak közvetlenül felelősek az általuk szolgáltatott adatok minőségéért.

- Hiányzott a LIBOR integritását biztosító központi felügyelet és a jegyzés során az elvárt mértékü függetlenség. Mivel a kamatjegyző bankok maguk is használói a benchmarknak, alacsony volt az ösztönzés arra vonatkozólag, hogy a kontroll típusú sztenderdeket teljes objektivitással és függetlenséggel be is tartsák.

A Wheatley riport alapján a LIBOR vizsgálatkori jegyzési folyamatának a fenntartása nem volt életképes opció, tekintettel az óriási hitelességvesztésre és a fixing eljárásban azonosított hiányosságokra. A jelentés megállapítása, hogy a kamatjegyzés folyamatát jelentősen meg kell erősíteni, a bizalom helyreállítása érdekében a LIBOR-t meg kell reformálni. Ezzel párhuzamosan a LIBOR szerepét részben, vagy egészben betölteni képes alternatív benchmarkokat is fel kell térképezni.

A LIBOR megerősítésének lehetőségeit, alternatív benchmarkkal való helyettesíthetőségét megvizsgálva a jelentés egy tíz pontból álló reformtervet fogalmazott meg:

- A LIBOR-jegyzés átfogó szabályozása

1) A felügyeleti hatóságoknak szabályozni kell a LIBOR müködtetését, illetve a jegyzési folyamatot. Meg kell határozni a független felügyeleti folyamatért felelős személyek körét, valamint a folyamat minden elemére kiterjedő kontroll-funkciók kialakítása szükséges. (A válság előtt a LIBOR jegyzését csak a Brit Bankszövetség (BBA) szabályozta, a felügyelő hatóság nem vett részt a folyamatban.)

- Intézményi reform

2) A LIBOR-ral kapcsolatos felelösség a Brit Bankszövetségtől kerüljön át egy új összefogó szervezethez, mely a bankközi referencia-kamatláb összeállításáért külső szereplők számára is hiteles belső irányításért és ellenőrzési mechanizmusért - felel. (Ennek eredményeképpen a jegyzések koordinálása 2014. február 1-én az IBA-hoz került.) 
3) Az új összefogó szervezetnek biztosítania kell a müködés transzparenciáját és a benchmark-kamatlábhoz való hozzáférést. Feladatai között szerepel az egyedi intézményi jegyzések ellenőrzése, illetve a LIBOR-értékek nyilvánosságra hozatala.

- LIBOR-jegyzés intézményi belső szabályozása

4) A LIBOR-jegyzésben résztvevő bankoknak a lehető legrövidebb időn belül gondoskodniuk kell arról, hogy a riportban (FSA [2012d]) megfogalmazott iránymutatásoknak megfeleljenek.

5) Az új összefogó szervezetnek egy magatartási kódexet - Code of Conduct (részletesebben FSA [2012d] 4. fejezet) - kell meghatározni a mindenkori jegyzést végző panelintézmények számára. (A jegyzés alapelveinek és nem kizárólag a technikai részleteinek rögzítése.)

- Jegyzést javitó azonnali intézkedések

6) A LIBOR-értékek azon devizák és futamidők esetén, ahol nincs megfelelő minőségü bázisul szolgáló tranzakciós adat, ne kerüljenek lejegyzésre és publikálásra. Amennyiben a probléma tartósan fennáll, akkor az érintett devizákat és futamidőket törölni kell a jegyzési folyamatból. (Azon tenorok, melyek nem tekinthetők aktívnak, kerüljenek ki a jegyzésből. A köztes tenorok adott esetben interpolációs formulával pótolhatók.)

7) A Brit Bankszövetség a LIBOR-jegyzés alapjául szolgáló egyedi szintü adatokat késleltetve, csak 3 hónap után hozza nyilvánosságra. (Az egyedi szintü hitelképességre vonatkozó jelzésből származó manipulálási ösztönző megszüntetése.)

8) A jegyzésben jelenleg nem résztvevő intézményeket ösztönözni kell a jegyzési folyamatban való részvételre. Ha másképp nem megoldható, akkor szabályozói elöírásokkal. (Annak a folyamatnak az elkerülése, hogy a megnövekedett költségek, illetve reputációs kockázatok miatt az intézmények jelentős része kivonuljon a jegyzésből és a panelekben csak kevés számú jegyző maradjon.)

9) A LIBOR-t használó piaci szereplöket ösztönözni kell, hogy döntéseiknél vegyék figyelembe a LIBOR használhatóságát, fontolják meg, hogy ez a 
benchmark a legalkalmasabb-e a végzett tranzakcióikhoz. (Egy inaktív tenor értéke nem minden körülmények között használható fel a döntéseknél. Például nettó jelenérték számításnál félrevezető eredményre vezethetnek, mely a kockázatkezelési döntéseket is hátráltatja.)

- Nemzetközi együttmüködés

10) Az Egyesült Királyság hatóságainak együtt kell müködniük a nemzetközi és európai uniós hatóságokkal a LIBOR és egyéb globális benchmarkok hosszú távú jövőjének érdekében. Az elemzési és konzultációs eljárás során többek között az alábbi alapelveket kell figyelembe venni (FSA [2012d] 6. és 7. fejezet):

- Lehetséges-e a LIBOR kiváltása más piaci benchmarkokkal?

- A tranzakciós adatok beépülnek-e a benchmark jegyzési folyamatába? Ki kell alakítani egy szigorú és részletes eljárásrendet, mely alapján összevethetök a tranzakciós adatok és a bankok által szolgáltatott fixing értékek. Emellett a publikált LIBOR-értékek körét leszükítik azon devizák és futamidők esetén, ahol nincs megfelelő számú tranzakciós adat a kialakuló LIBOR-érték alátámasztására.

- A piaci szereplőknek továbbra is jelentős szerepet kell vállalniuk a LIBOR-jegyzésben és a jegyzési folyamat felügyeletében.

\subsubsection{GFMA: Principles for financial benchmarks}

A Global Financial Markets Association ${ }^{29}$ (GFMA) 2012. szeptember 7-én bocsátotta ki a konkrét javaslatokat tartalmazó ajánlását a pénzügyi benchmarkok teljes körére vonatkozóan. A dokumentum alapvető célja volt felhívni a figyelmet olyan nemzetközi sztenderdek szükségességére, melyek a pénzügyi benchmarkok körére vonatkoznak.

A GFMA dokumentuma kilenc alapelvet fogalmazott meg, melyek az irányításon, a módszertanon és az ellenőrzésen keresztül a teljes benchmark-képzési folyamatra kiterjednek:

\footnotetext{
${ }^{29}$ A Global Financial Markets Association (GFMA) a világ három vezető pénzügyi szövetségét (Association for Financial Markets in Europe (AFME), Asia Securities Industry \& Financial Markets Association (ASIFMA) és Securities Industry and Financial Markets Association (SIFMA)) foglalja magába.
} 
- Irányítás (governance)

1) Teljes és átfogó felelősség - Egy szponzorra ${ }^{30}$ hárul a felelősség a benchmark minőségéért és integritásáért. A szponzornak ki kell jelölnie és megfelelő hatáskörrel fel kell ruháznia egy vezető testületet, mely elszámoltatható a benchmark kialakításáért és müködéséért. A testület hatáskörébe tartozik a benchmark módszertanának, ellenőrzési mechanizmusának, illetve a szponzor és harmadik fél közti kapcsolatainak felügyelete.

2) Tiszta szerepek és felelősségek - A szponzornak egyértelmüen rögzítenie kell a benchmark folyamatban résztvevők (beleértve harmadik feleket is) szerepét és felelösségeit. Ha a rögzítési folyamat legalább két funkcióját egy intézményen belül végzik, akkor biztosítani kell, hogy szétválaszthatók legyenek a különböző benchmark-funkciók közötti, illetve a benchmark-funkciók és az intézmény tevékenységei közti összeférhetetlenségek.

3) Transzparencia - A benchmark kialakítása és későbbi megváltoztatása során a szponzornak transzparensen kell müködnie, és nem hagyhatók figyelmen kívül a folyamatban résztvevőkre és a végfelhasználókra gyakorolt hatások.

\section{- Módszertan és minőség}

4) Módszertan - A szponzornak olyan benchmarkot előjegyző módszertant kell biztosítania, amely megbízható és stabil adatokon alapul, és tükrözi a piac aktuális állapotát.

5) Minőség - A benchmark minőségének biztosítására a szponzornak a lehető legjobb gyakorlatot (best practice) kell követnie. Azokon a piacokon, melyeken benchmarkot jegyeznek, megfelelö volumenü kereskedési tevékenységre van szükség abból a célból, hogy a jegyzett értékek képesek legyenek a piac állapotát megjeleníteni. Minden lehetséges lépést meg kell tenni, hogy a benchmark jegyzésében és használatában minél szélesebb kör vegyen részt.

- Ellenörzés

6) Ellenőrzési keretrendszer - A szponzornak gondoskodnia kell a teljes benchmark eljárás megfelelő ellenőrzési mechanizmusáról (megfelelően kvalifikált

\footnotetext{
${ }^{30}$ Szponzor egy intézményt vagy csoportot jelöl, mely kifejleszt egy benchmarkot, és irányítja annak teljes múködését
} 
munkatársak, technikai és etikai tréning, eljárásrend az összeférhetetlenségek kiszürésére, a folyamatokra, az adatminőségre, a hibák felderítésére stb.).

7) Független vizsgálat és adattárolás - A benchmark-jegyzési eljárást és módszertant rendszeresen felül kell vizsgálni, a folyamatot megfelelően dokumentálni kell. A vizsgálatnak ki kell terjednie a benchmark-jegyzés módszertanára, az ellenőrzési mechanizmusokra, a valós piaci tranzakciókra és minden további - ebben az ajánlásban lefektetett - alapelv teljesülésére.

8) Adatgyüjtés - A szponzornak biztosítania kell, hogy a jegyzés során az adatgyüjtést megfelelő ellenőrzési mechanizmus védi. A mechanizmusnak ki kell terjednie többek között az adatforrás választására, az adatforrástól származó adatok begyüjtésére és értékelésére, az adatok védelmére, a jegyzések bejelentésének folyamatára, illetve az adatbejelentés elmulasztása esetén érvényes szankcionálásra.

9) A jegyzésben résztvevők magatartási kódexe - A szponzornak biztosítania kell, hogy a jegyzést végző intézményeken belül az adatjelentésre vonatkozó sztenderdeket tartalmazó magatartási kódexet alkalmazzanak. Ez a kódex minimálisan a következőket tartalmazza:

- az adatjelentésre vonatkozó megfelelő irányítási struktúra és eljárásrend,

- összeférhetetlenségek kiszürésére vonatkozó eljárásrend,

- más adatjelentő intézményekkel történő információ-megosztás és cselekvési koordináció tiltása,

- a jegyzési folyamatban résztvevő szereplők hatásköreinek és felelősségeinek egyértelmű rögzítése,

- a jegyzéssel összefüggő panaszok kezelésére, a bizalmas információk védelmére, illetve az adatjelentőkre vonatkozó eljárásrend megsértése esetén alkalmazandó intézkedésekre kiterjedő eljárásrend,

- az adatjelentés időbeni és tartalmi pontosságát támogató infrastruktúra,

- készenléti terv azon az esetekre, amennyiben az adatjelentés infrastruktúra hibából nem valósul meg,

- a jelentett adatok archiválásának eljárásrendje,

- a rendszeresen végrehajtandó ellenőrzések rendje. 
- a magatartási kódex alkalmazásán túl az adatjelentőknek a bejelentés teljes körét lefedő ellenőrzési mechanizmus müködtetése.

\subsubsection{EBA-ESMA ${ }^{31}$ : strengthen Euribor and benchmark rate-setting processes}

Az Európai Bankfelügyelet (EBA) és az Európai Értékpapír- és Piacfelügyelet (ESMA) közös munkacsoportja 2012 októberében és novemberében az EURIBOR-ról végzett vizsgálatot. A munkacsoport ajánlásai a meglévő hiányosságok és gyengeségek tekintetében az azonnal végrehajtandó intézkedésekre fókuszálnak. A publikáció főbb részei az alábbiak:

- az EURIBOR-European Banking Federation-nek (EEBF) és az EURIBOR jegyzést végző intézmények nemzeti felügyeleti hatóságainak címzett ajánlások,

- az Euribor fixing eljárás főbb gyengeségeire és hibáira fókuszáló vizsgálati jelentés,

- valamint a benchmark jegyzésre vonatkozó konzultációra bocsátott alapelvek.

A jelentés megállapításai és ezek alapján az EEBF-nek címzett ajánlások:

1) Az ellenőrzési mechanizmus azonnali megerősítése.

2) Az EEBF Steering Committee összetételének kibővítése független tagokkal, hogy a jegyzést végző bankokhoz kötődő tagok kisebbségbe kerüljenek.

3) A Steering Committee legalább kéthavonta ülésezzen, és az üléséről készült jegyzőkönyvet publikálja.

4) Csak a leggyakrabban alkalmazott és legnagyobb volument adó lejáratok kerüljenek megtartásra. A jelenlegi 15-ről csökkenteni kell a jegyzési tenorok számát. A jegyzett tenorok száma ne haladja meg a 7-et (1 és 2 hét, 1, 3, 6, 9, 12 hónap).

5) Az EURIBOR definícióját pontosítani kell. Precízebben meg kell határozni a „prime bank” és az ,interbank transaction” fogalmakat.

6) Az EEBF-nek teljes felelősséget kell vállalnia az EURIBOR jegyzési eljárásra, beleértve a bankok által jelentett adatok, illetve a Thomson Reuters által számított és közölt adatok minőségi ellenőrzését is.

7) Meg kell erősíteni az EEBF irányítását, és a magatartási kódexét is jobban ki kell dolgozni, a fennálló összeférhetetlenségeket pedig meg kell szüntetni.

8) Az EEBF folytasson rendszeres belső ellenőrzéseket.

\footnotetext{
${ }^{31}$ European Banking Authority - European Securities and Markets Authority
} 
9) A Thomson Reuters is készítsen saját maga számára magatartási kódexet és folytasson belső ellenőrzéseket. Lehetöleg az EEBF évente egyszer a Thomson Reuters-nél is hajtson végre ellenőrzést.

10) Mind az EEBF, mind a Thomson Reuters évekre visszamenőleg tárolja a jegyzést végző bankok által jelentett adatokat.

Az EURIBOR-panelt adó bankok illetékes nemzeti felügyeleti hatóságai számára címzett ajánlások:

- Az adatok jelentése legyen része a jegyző bankok kockázatkezelési és ellenőrzési politikájának. A bankok építsék be a négy-szem elvet ${ }^{32}$ a jegyzési folyamatba.

- A jegyző bankok készítsenek az adatok jelentési folyamatára vonatkozó magatartási kódexet. A nemzeti felügyeleteknek támogatniuk kell ezen kódexek elkészítését és alkalmazását.

- A jegyzésben résztvevő bankokban az adatot jelentő személyeknek és feletteseiknek írásban kell vállalniuk, hogy betartják a vonatkozó magatartási kódex előírásait.

- Az EURIBOR panelbankokat az EURIBOR adatok jelentésének vonatkozásában a nemzeti felügyeleti hatóságoknak kell felügyelni. Az EEBF majdani felügyeleti hatóságának együtt kell müködnie az érintett illetékes nemzeti felügyeleti hatóságokkal. A felügyelési folyamatbank magában kell foglalnia a szankcionálás lehetőségét.

- Az illetékes hatóságoknak ösztönözniük kell a piacokon aktív bankokat, hogy részt vegyenek a jegyzési folyamatban.

\subsubsection{IOSCO: Consultation Report on Financial Benchmarks}

Az International Organization of Securities Commissions (IOSCO) 2012 szeptemberében egy munkacsoportot állított fel, melynek feladata volt annak meghatározása, hogy jelenleg a piacokon milyen típusú benchmarkok vannak, illetve annak azonosítása, hogy ezen bechmarkok milyen termékekhez köthetőek. Emellett a munkacsoport feladata volt globális alapelvek és ajánlások kidolgozása is.

\footnotetext{
${ }^{32}$ Egy aktív kamatjegyző intézmény csak abban az esetben küldhesse el az adott napi jegyzését, ha a jegyzésért felelős munkatárs által rögzített értékeket az intézmény egy másik, megfelelő szaktudással rendelkező alkalmazottja is megerösítette.
} 
Az IOSCO munkacsoportja definíciója alapján egy bechmarknak az alábbi tulajdonsággal kell rendelkeznie:

1) Reprezentativitás - a referencia-érték kellőképpen jelenítse meg az érintett piaci szegmens tulajdonságait.

2) Megbízhatóság - az adatok megfelelő minőségüek legyenek, és ez a piaci szereplők számára is hihetö legyen.

3) Transzparens - a számítási folyamat minden szereplő számára egyértelmű és áttekinthető legyen.

4) Átlátható irányítási, jegyzési és ellenőrzési funkciókkal rendelkezik.

A vizsgálat kilenc referencia-érték kategóriát azonosított kihangsúlyozva, hogy a kategorizálás nem teljeskörü, hiszen nem terjed ki minden területre (pl. a költségvetési mérőszámokra). Az azonosított kilenc kategória a következő volt:

- bankközi piaci ajánlati referencia-kamatlábak (pl. LIBOR, TIBOR ${ }^{33}$, EURIBOR, $\mathrm{CIBOR}^{34}, \mathrm{BBSW}^{35}$ ),

- napon belüli (overnight) hitel és repo piaci referencia-ráták (pl. EONIA ${ }^{36}$, HUFONIA $^{37}$,

- csereügyletekhez (swap piac) kapcsolódó benchmarkok (pl. OIS ${ }^{38}$, ISDAFIX $^{39}$ ),

- részvénypiaci referencia-értékek, tőzsdekosarak,

- hitelpiaci (többek között államkötvényekhez, vállalati kötvényekhez és CDS-hez kapcsolódó) referencia-értékek,

- árupiaci bechmarkok,

- energiapiaci referencia-ráták,

- devizapiaci referencia-értékek,

- alternatív befektetési formák (pl. hedge fund) referencia-indexei.

A munkacsoport által 2013. január 11-én kiadott és konzultációra bocsátott jelentés több elvi kérdést, alapelvet foglal magába. A megállapítások öt területre tagolódnak:

\footnotetext{
${ }^{33}$ Tokio Interbank Offered Rate

${ }^{34}$ Copenhagen Interbank Offered Rate

${ }^{35}$ Bank Bill SWAP Reference Rate - Ausztrália referencia-kamatlába

${ }^{36}$ Euro OverNight Index Average

${ }^{37}$ Hungarian Forint Overnight Index Average. Definíciót lásd 8.7. Melléklet.

${ }^{38}$ Overnight Index Swap

${ }^{39}$ 1998-ban az ISDA által kialakított, az egész világra kiterjedő tranzakciókon alapuló éves swap ráta referenciaértéke. Lásd bővebben: http://www2.isda.org/asset-classes/interest-rates-derivatives/isdafix.
} 
1) Módszertan - a jelentés kitér mind mennyiségi, mind integritási szempontokra. Kiemeli az adatminőség szerepét, az adatellenőrzések fontosságát és a számítási módszertanokban fellelhető hiányosságokat.

2) Transzparencia - a transzparenciának ki kell terjednie a módszertanokra. Ez a tulajdonság egy piaci stresszhelyzet vagy módszertanváltás esetén sem sérülhet. Kiemelt kérdéskör, hogy a nyilvánosságra hozott értékeket a jegyzést végző intézmények semmilyen jelzésre sem használhassák.

3) Irányítás (governance) - a legfontosabb szempont, hogy a jegyzést végszó szervezeti folyamatnak függetlennek kell lennie az intézmény többi olyan üzleti folyamatától, melyek adott esetben ösztönzőleg hathatnánk a fixing folyamatra.

4) Elszámoltatás - a jegyzést végző személyek elszámoltathatók kell, hogy legyenek. A döntéseiknek adott esetben legyenek következményeik.

5) Ellenőrzés - a benchmarknak egy robosztus ellenőrzési rendszerrel kell rendelkeznie, mely megfelelő szintű eljárásrendeken és szabályzatokon alapul. Emellett a jegyzésekben résztvevők számára egy magatartási kódex kialakítása is elvárt.

\subsubsection{EBA - ESMA javaslat az Európai Bizottság számára a benchmarkokra vonatkozó keretszabályozás kialakításához}

A lezajlott felügyeleti vizsgálatok és konzultációk eredményeképpen az EBA és az ESMA közös szempontokat dolgozott ki a benchmarkok szabályozói reformjára, melyet a törvényalkotási joggal rendelkező Európai Bizottság felé továbbítottak ${ }^{40}$.

Az EURIBOR vizsgálata alapján nyilvánvaló, hogy a referencia-érték jegyzési folyamatokat szabályozni és felügyelni kell. A szabályozásnak a vállalatirányításra, a rendszerekre és a kontrollokra, valamint összeférhetetlenségre is ki kell terjednie. A szabályozásnak és a felügyelésnek le kell fednie a teljes folyamatot, és a folyamat valamennyi résztvevőjét.

\footnotetext{
${ }^{40}$ A fenti mondat is tükrözi az európai szintü jogalkotási folyamat lassúságát. Az EBA és az ESMA sem rendelkezik rendeletalkotási jogkörrel, csak ajánlásokat és szabályozási tervezeteket tesz közzé a honlapján. A törvényerejü rendeletek kiadásának hatásköre az Európai Bizottsághoz tartozik, melynek folyamatba való belépése sok esetben 6-12 hónappal késleltetheti a jogszabály életbe léptetését.

A benchmarkokkal kapcsolatosan a probléma komplexitása okán elsősorban ajánlásokat alakítottak ki, a jogszabályi szintre emelés sok esetben olyan kérdéseket vet fel, melyek teljes körü jogi megoldása akár több évet is igénybe vehet.
} 
Kiemelten fontos, hogy a jegyzési folyamatot ne tudják befolyásolni azon személyek, akiknek érdekeltségük van (és ezáltal ösztönzésük az eltérítésre) a jegyzés eredményében. A szerepek szétválasztása és az összeférhetetlenségek kiszürése szabályozói szinten biztosítandó.

Szabályozói előírásként érdemes figyelembe venni egy benchmark esetében a tranzakciók minimum számának/értékének a meghatározását. Az alkalmazott tenorok körének rendszeres áttekintése a transzparencia biztosítása szempontjából is hangsúlyos.

\subsection{A manipulációs botrány hatása más benchmarkokra}

A LIBOR manipulálásának kapcsán azonosított problémáknak jelentős kihatása van számos más referencia-értékre mind a pénzügyi világban, mind azon kívül. Az IOSCO vizsgálta az olaj spot árakat, míg az európai hatóságok az EURIBOR-t vették vizsgálat alá. Az EURIBOR vizsgálat eredményei a fentebb ismertetett szabályozói jelentésekben és ajánlásokban is megjelentek.

A bankközi piaci kamatlábak tekintetében több európai országban is vizsgálatok indultak a helyi referencia-értékek vonatkozásában. Vizsgálat alá került többek között Dániában a $\mathrm{CIBOR}^{41}$, Lengyelországban a WIBOR ${ }^{42}$ és Magyarországon a BUBOR is.

\subsection{Magyarországi hatás - pénzügyi felügyeleti vizsgálat}

A Barclays manipulálási ügye Magyarországon is felkeltette a figyelmet a LIBOR-hoz hasonló módszerekkel számított bankközi kamatláb, a BUBOR iránt. A Pénzügyi Szervezetek Állami Felügyelete (PSZÁF) 2012 őszén indított témavizsgálatot a budapesti referencia-ráta jegyzésének vizsgálatára. A vizsgálat különösen nagy figyelemmel zajlott, hiszen egy esetleges manipulációra utaló megállapítás is jelentős következményekkel járt volna. Fontos hangsúlyozni, hogy a vizsgálat a jegyzést végző intézmények érdekében is állt, hiszen segítségével véglegesen cáfolhatóvá válik a manipulálás gyanúja és tovább erősíthető a BUBOR-ba vetett bizalom ${ }^{43}$ is. Ugyanakkor a vizsgálat nem kizárólag a manipuláció megállapítására vagy cáfolatára irányult. A Felügyelet át kívánta tekinteni a BUBOR jegyzési folyamatát, és adott esetben megállapítani az esetlegesen meglévő gyengeségeket, hogy ezen

\footnotetext{
${ }^{41}$ Copenhagen Interbank Offered Rate

${ }^{42}$ Warsaw Interbank Offered Rate. Definíciót lásd 8.7. Melléklet.

${ }^{43}$ A 2008-2009-es válság következtében kialakult devizahiteles sokk eredményeképpen létrejött negatív bankellenes hangulatot még jelentősen tovább rontotta volna egy esetlegesen nyilvánosságra kerülő manipuláció ténye. A piaci várakozásoknak megfelelően a PSZÁF 2013 februárjában kinyilvánította (PSZÁF [2013]), hogy nem talált manipulációra utaló jeleket.
} 
hiányosságok pótlása után a magyar intézmények egy még transzparensebb referencia-értéket jegyezzenek.

A felügyelet vizsgálatának a fókuszpontjában a következő szempontok álltak:

- van-e a BUBOR-jegyzésben résztvevő intézményeknél olyan belső kockázat-kezelési mechanizmus, amely az esetleges manipulálásra irányuló cselekedetek elkerülését vagy azok felderítését szolgálja;

- van-e ezen intézményeknél olyan belső dokumentáció és eljárásrend a napi jegyzések kialakításáról, amely lehetővé teszi a jegyzési folyamat minden lépésének ellenőrzését, a jegyzések utólagos visszakeresését;

- van-e olyan intézmény, amelynek a BUBOR jegyzése rendszeresen jelentősen eltért az a többi szereplő jegyzésétől, és ha azonosítható ilyen, akkor mi lehet ennek az oka és mekkora a hatása végső aggregált BUBOR értékekre;

- amennyiben több intézmény összehangolt magatartása merülne fel, akkor mekkora mértékben érintett a Felügyelet, mennyire terjedhet ki az intézkedési jogköre és ez mennyire lenne tekinthető egy negatív piaci befolyásolás egyszerü versenyjogi (kartell) kérdésének és tartozna a Gazdasági Versenyhivatal (GVH) hatáskörébe az eset;

- mennyire pontosan van megfogalmazva az intézmény számára, hogy a jegyzéskor az általa leadott kamatok megállapításánál mit vehet figyelembe és mit nem (pl. a jegyzéskor beadandó értékek kialakításakor a média hírei, a reputációs érdekek nem lehetnek befolyásoló tényezők);

- meg van-e benne határozva, hogy likviditási válság esetén, ha kiszárad a piac vagy bizonyos lejáratok esetén drasztikusan lecsökken az üzletkötések száma, akkor milyen eljárás követendő, milyen mechanizmusok mentén kerül meghatározásra a BUBOR. 


\section{A budapesti bankközi forint hitelkamatláb}

\subsection{A Budapesti bankközi forint hitelkamatláb története}

A Magyar Forex Társaság (MFT) kezdeményezésére 1995 áprilisában a magyar kereskedelmi bankok elhatározták, hogy megteremtik a nemzetközi kamatbenchmarkok mintájára a budapesti bankközi hitelkamatlábat, a BUBOR-t. Az MFT Szakmai Bizottsága és az MNB által delegált tag részvételével nyolctagú munkacsoport alakult, amely a nemzetközi tapasztalatok alapján, a kereskedelmi bankokkal egyeztetve kidolgozta a BUBOR megállapításának módszertanát.

Az MFT Szakmai Bizottsága a BUBOR-szabályzat tervezetét 1996. július 1-i ülésén megvitatta és elfogadta. A BUBOR-jegyzés 1996 augusztusában indult el. Az első szabályzatban a BUBOR alkalmazását tőzsdei és tőzsdén kívüli származékos kamatügyletek elszámolásánál, valamint változó kamatozású aktívák és passzívák bázisául javasolták a létrehozók. Ekkor vételi és eladási ajánlatokat (bid/offer) egyaránt jegyeztek maximum 100 bázispontos kamatréssel két futamidő (1 illetve 3 hónap) vonatkozásában. A kamatrés mértékét a BUBOR-szabályzat rögzítette. 1996-ban nyolc aktív kamatjegyző bank volt. A BUBOR meghatározása a két legalacsonyabb és a két legmagasabb jegyzés kiejtésével történt. Az MNB a beadott jegyzéseket azonnal továbbította két devizapiaci bróker, az Eurowien és az FX Rt részére. A beadott jegyzések futamidőnként 100 millió forintig ügyletkötési kötelezettséggel is jártak.

Az első szabályzatmódosítás 1997. május 1-jén történt, figyelembe véve az első tíz hónap tapasztalatait. Bevezették a 6 hónapos futamidőt, és a jegyzéseknél minimális kamatrést (25 bázispont) is bevezettek. Már ekkor említés történt az aktív BUBOR-piac kialakulásának egyik fö akadályát jelentő, az egyes bankok közötti limitproblémákról ${ }^{44}$.

1999. június 1-jével bevezették az overnight $(\mathrm{O} / \mathrm{N})^{45}$ futamidőt. Az üzletkötési kötelezettséget 200 millió forintra emelték, mely alól az overnight futamidő kivételt jelentett. 2002. május 1jével bővült a jegyzett futamidők száma, jegyezni kezdték az 1 és 2 hetes, illetve 9 és 12 hónapos futamidőket. Megszűnt az üzletkötési kötelezettség. Az aktív BUBOR-jegyző bankok száma 16-ra bővült, listájukat az MNB közremüködésével háromhavonta vizsgálta

\footnotetext{
${ }^{44}$ Már 1997-ben is problémát okozott, hogy a BUBOR-jegyzésben résztvevő intézmények több esetben nagyon alacsony pozíciós limitekkel rendelkeztek a fedezetlen forinttermékek vonatkozásában egymással szemben. Több esetben ezen limitek fenntartását az anyabankok nem is támogatták.

${ }^{45}$ Definíciót lásd 8.7. Melléklet.
} 
felül az MFT Szakmai Bizottság. A bankok kiválasztása az elmúlt időszak forgalmi statisztikáin alapult. Ekkor a BUBOR meghatározás metódusa is módosult, a négy legkisebb illetve a négy legnagyobb értéket elhagyták az átlagolásból.

3. táblázat: A BUBOR-jegyzés főbb paramétereinek változása 1996 - 2014

\begin{tabular}{|c|c|c|c|c|c|}
\hline & $\begin{array}{c}\text { Tenorok } \\
\text { száma }\end{array}$ & $\begin{array}{l}\text { Jegyzők } \\
\text { száma }\end{array}$ & $\begin{array}{l}\text { Nyesés } \\
\text { mértéke }\end{array}$ & $\begin{array}{c}\text { Bid\&Offer } \\
\text { jegyzés }\end{array}$ & $\begin{array}{c}\text { Üzletkötési } \\
\text { kötelezettség }\end{array}$ \\
\hline 1996 & 2 & 8 & $2-2$ & igen & igen (100 mHUF) \\
\hline 1997 & 3 & 8 & $2-2$ & igen & igen (100 mHUF) \\
\hline 1999 & 4 & 8 & $2-2$ & igen & igen (200 mHUF) \\
\hline 2002 & 8 & 16 & $4-4$ & igen & nincs \\
\hline 2003 & 15 & 16 & $4-4$ & csak bid & nincs \\
\hline 2013 & 15 & 12 & $3-3$ & csak bid & nincs \\
\hline 2014. febr. & 9 & 10 & $2-2$ & csak bid & nincs \\
\hline 2014. aug. & 9 & 9 & $2-2$ & csak bid & nincs \\
\hline
\end{tabular}

forrás: MFT, saját szerkesztés

2003. szeptember 15-én ismét bővítették a futamidőt. Ettől kezdve O/N, 1- 2 hét,1-2-3-4-5-67-8-9-10-11-12 hónapos futamidőket jegyezték. Az aktív piac problémáit mutatta, hogy bár 15 tenorban történt jegyzés, az offer értékek rögzítése megszűnt. Kizárólag bid értékeket adtak meg a jegyző intézmények. Ezzel párhuzamosan az aktív jegyző bankok kiválasztásához alkalmazott forgalmi statisztikát kibővítették került a megelőző negyedévben kötött FX-swap ügyletek forint lábának összegével.

A BUBOR jegyzés technikai háttere 2003. november 1-től megváltozott. Mivel a 16 aktív kamatjegyző bank mindegyike napi 15 jegyzést adott, az MNB-nek napi 240 jegyzést kellett feldolgozni, mely az induláshoz képest jelentősen megnövelte a kezelt adatok méretét. Ekkortól a bankok a Reuters által rendelkezésre bocsátott, csak az illető bank illetve az MNB számára látható kontribúciós oldalon adták be jegyzéseiket. A kontribúciós oldal excel táblából frissíthető, ami a jegyző bankok munkáját is megkönnyíti.

A 2008-as gazdasági válság tovább szükítette a korábban is szükös BUBOR-piacot, melyet a 2012-ben kirobbant LIBOR-botrány tovább erősített. A negatív hatások révén a több BUBOR-jegyző bank kilépett a rögzítési folyamatból. Ennek a csökkenő folyamatnak a további megakadályozására, és a szabályozói elvárásoknak is megfelelve a Magyar Forex 
Társaság 2013 májusában egy új BUBOR-szabályzatot adott ki. A jegyzési folyamatban 2013 májusától 12 kereskedelmi bank vesz részt. A BUBOR jegyzés 15 tenorban történik, és a 3-3 legkisebb illetve legnagyobb jegyzett érték esik ki a nyesés során. 2014. február 1-tôl a jegyzett futamidők számát 9-re csökkentették (O/N, 1- 2 hét,1-2-3-6-9-12 hónap). A csökkenés az aktív kamatjegyzők számát is érintette, 2014 augusztusától mindössze 9 intézmény jegyzésein alapult a budapesti referencia-érték.

\subsection{Budapesti bankközi hitelkamatláb definíciója}

Az MFT szabályzata (Magyar Forex Társaság [2013]) 2013. január 1-én meglehetősen szükszavúan határozta meg a Budapesti bankközi forint hitelkamatlábat (BUBOR-t):

„Bankközi hitel nyújtására tett üzleti ajánlat kamatlába.”

„A fixing számításba bekerülö kamatokat az aktív kamatjegyzö bankok minden magyar banki munkanapon, a mellékletben meghatározott idöpontban ${ }^{46}$ a rendelkezésükre álló módon szükség esetén telefaxon - közlik a kamatok rögzitését és összegzését végzö Magyar Nemzeti Bankkal. Az aktív kamatjegyzö bankok kötelezik magukat arra, hogy az általuk beadott kamatjegyzések az árjegyzés időpontjában élö valós bankközi hitelkamatlábnak felelnek meg."

A PSZÁF BUBOR-vizsgálatának és a hozzá kapcsolódó ajánlásának alapján a BUBORszabályzatban a definíciót pontosították (Magyar Forex Társaság [2014]):

„Azon az adott kamatjegyzést szolgáltató bank által meghatározott kamatlábat jelenti, amely kamatlábon a kamatjegyzést szolgáltató bank legjobb tudomása és megitélése szerint az adott magyar banki munkanapon, a Melléklet 2. pontjában foglalt idöpontban ${ }^{47}$, a Melléklet 3. pontjában megjelölt futamidők vonatkozásában ${ }^{48}$ (...) az 5.1 pont szerint meghatározott aktív kamatjegyzö bank egy másik aktív kamatjegyzö bank részére fedezetlen bankközi hitel (ún. unsecured interbank loan) nyújtására üzleti ajánlatot tenne."

A BUBOR-szabályzat változásából is látható, hogy a LIBOR-botrány előtti egyik hiányosság a transzparens szabályozottság hiánya. Bár a kamatjegyző bankok fixinget végző munkatársai és a piaci szereplők számára 2013 előtt is nyilvánvaló volt, hogy a BUBOR fedezetlen

\footnotetext{
${ }^{46} 10: 30$

47 10:15-10:30 között

${ }^{48}$ overnight $(\mathrm{O} / \mathrm{N}), 1$ hét, 2 hét, 1, 2, 3, 6, 9 és 12 hónap
} 
bankközi hitelek kamatlábát jeleníti meg, a szabályzat azonban nem tartalmazta ezt az elvárást, vagyis a jegyzést végzők számára ez irányból semmilyen szabályzatbeli megkötés nem szerepelt. További fontos módosítás ,az aktív kamatjegyző bank egy másik aktív kamatjegyző bank részére” kitétel. Ha pusztán egy külső szereplő szemszögéből indulunk ki, egyáltalán nem hagyható figyelmen kívül, hogy a referencia-érték kizárólag a kamatjegyzők (és ezáltal a legnagyobb piaci szereplők) kockázatát, vagy a bankközi piac minden szereplőjének, így akár egy nagyon csekély piaci részesedéssel rendelkező takarékszövetkezetnek a kockázatát is meg kell, hogy jelenítse.

A BUBOR a LIBOR-hoz hasonlóan a jegyzésekből egy nyesett átlagként adódik. A számítási módszertan esetében a szabályzat változásánál a kamatjegyzői kör szükülése jelenik meg. 2013-ban a nyesések számát még fixen (négy legmagasabb és négy legalacsonyabb jegyzés) határozta meg a szabályzat:

„...a futamidőnkénti négy - négy legmagasabb és legalacsonyabb offer elhagyásával kiszámítja az aznap rögzítendö BUBOR kamatlábakat..."

2014-től a nyesés mértéke a kamatjegyzők számához kötött (Magyar Forex Társaság [2014]): „Az adott magyar banki munkanapon és az adott futamidö vonatkozásában a Magyar Nemzeti Bankhoz (MNB) beérkezett kamatjegyzések tekintetében:

(a) a négy legmagasabb és négy legalacsonyabb kamatjegyzést jelenti, amennyiben a beérkezett kamatjegyzések száma eléri a 16-ot;

(b) a három legmagasabb és három legalacsonyabb kamatjegyzést jelenti, amennyiben a beérkezett kamatjegyzések száma eléri vagy meghaladja a 12-öt, de nem éri el a 16-ot;

(c) a két legmagasabb és két legalacsonyabb kamatjegyzést jelenti, amennyiben a beérkezett kamatjegyzések száma eléri vagy meghaladja a 7-et, de nem éri el a 12-öt;

(d) a legmagasabb és a legalacsonyabb kamatjegyzést jelenti, amennyiben a beérkezett kamatjegyzések száma nem éri el a 7-et."

A módosított szabályzatból látható, hogy az MFT a kamatjegyzők körének szükülésével számolt. A szabályzat nem veszi figyelembe a kamatjegyzők számának növekedéséből származó kockázatokat, így azt a tényt, hogy egy szélsőséges jegyzés nagyobb valószínűséggel maradhat az átlagszámításban. Ugyanakkor megjegyzendő, hogy ez utóbbi eshetőség a közeljövőben nem áll fenn, hiszen 2014 februárjától a kamatjegyző bankok száma 
10-re csökkent, mely jelentősen elmarad a BUBOR-jegyzés „fénykorát” jelentő 16-os szinttől. ${ }^{49}$ A kivonulás elsődlegesen a LIBOR-botrány és ennek következtében a referenciakamatlábakra irányuló fokozottabb figyelem következménye. A magyar piacon tevékenykedő kevésbé jelentős piaci részesedéssel rendelkező külföldi tulajdonú intézmények a jegyzésből származó reputációs kockázatokat sokkal nagyobbnak ítélték meg a járulékos hasznoknál, így 2012 óta több szereplő kivonult a jegyzésből.

\subsection{A BUBOR és a LIBOR közötti leglényegesebb különbségek}

A korábbi fejezetekben bemutatott LIBOR és BUBOR definíció alapján látható, hogy a két referencia-kamatláb bár nagyon hasonló, teljes mértékben a BUBOR mégsem feleltethető meg a LIBOR budapesti megfelelőjének. A következő bekezdésekben a legfontosabb különbségeket foglalom össze, melyek kiemelten fontosak a jegyzések elemzésénél tett megállapítások felállításához is.

A LIBOR-jegyzés során a jegyző bank a forrásköltsége bemutatásával (mennyiért jutna fedezetlen bankközi forráshoz) saját hitelkockázatát minősíti, önmagáról állít ki hitelminősítést. A BUBOR - a LIBOR-tól eltérően ${ }^{50}$ és az EURIBOR-hoz hasonlóan - egy kínálati kamatlábat tükröz, amely mellett adott bank fedezetlen bankközi hitelt nyújtana. A fedezetlen bankközi hitelek árazásában a forrásköltség mellett több más tényező - köztük a jegyző bank napi likviditási helyzete, eszköz-forrás szerkezete - is közrejátszik. A BUBOR definíciója alapján azonban a jegyzés közvetlenül nincs hatással a jegyző bank reputációjára, mivel nem a saját piaci megítéléséről, hanem a többi piaci szereplőről mond véleményt, ezért a LIBOR-ral ellentétben a definíció nem ösztönöz szignálozáson keresztüli manipulációra. A BUBOR esetén a LIBOR-hoz hasonló, reputáció miatti manipulációs kockázat csak közvetetten merülhet fel.

Fontos különbség, hogy míg a LIBOR esetében az ajánlatgyüjtést, az átlagolást és a publikálást is a Reuters végezte, addig Magyarországon ezt a szerepet a Magyar Nemzeti Bank töltötte be, ezzel stabilitást adva az eljárásnak, és előzetes szűrést, ellenőrzést is végzett a jegyzések során.

\footnotetext{
${ }^{49}$ Azonban az a tény sem hagyható figyelmen kívül, hogy a BUBOR-szabályzat 2014-es módosításáig fixen 4-4 érték került elhagyásra, így 2013 folyamán 13 jegyzö bank esetén mindössze öt bank jegyzése adta a BUBORértéket.

${ }^{50}$ A LIBOR esetében a kamatjegyző intézménynek arra kell válaszolnia, hogy mennyiért jutna fedezetlen forráshoz. (BBA [2014])
} 
Az EURIBOR- és a LIBOR-jegyzés során a nyesés (a legalacsonyabb és a legmagasabb jegyzők kiejtése a számításból) a jegyzésben részt vevő bankok arányában került meghatározásra, az EURIBOR-nál 15-15\%, a LIBOR-nál 25-25 \% esik ki. A BUBOR esetében 2014-ig ez rögzített érték volt, a négy legalacsonyabb, illetve a négy legmagasabb jegyzés kerül ki az átlagolásból (pl. 2013-ban 13 aktív kamatjegyzőböl az öt középértéket jegyző bank jegyzésének átlaga adta a hivatalos BUBOR-értéket).

A BUBOR-jegyzést a bankok pénzpiaci (money market) szakterületei ${ }^{51}$ végzik, ahol a legkisebb a BUBOR alapján árazódó derivatív pozíciók mérete. Az éven belüli sajátszámlás kereskedési pozíciók nagysága a jegyző bankon belül itt a legkisebb, ellentétben egy kötvény (fixed income) vagy a banki könyvet vezető eszköz-forrás kezelő (ALM trading ${ }^{52}$ ) területtel, így itt kisebb az összeférhetetlenség kockázata.

A forinthoz kötött kamatpozíciók nagyságrendekkel kisebbek, mint a LIBOR- vagy EURIBOR-értékek alapján átárazódó kereskedési könyvi pozíciók a nemzetközi piacokon, emiatt a kereskedési pozíciók miatti manipulálás kockázata is lényegesen alacsonyabb, hiszen a piaci szereplők számára sokkal kevesebb ösztönzőt jelentenek.

\subsection{A budapesti bankközi hitelkamatláb beépülése a jogalkotási folyamatba}

Egy referencia-kamatláb piaci folyamatokba való beépülését hủen tükrözi a jogszabályokban való megjelenése. A jogszabályi jelenlét súlyt ad a referencia-kamatlábnak, még erősebben legitimálja és a társadalom minden számára azt az üzenetet tükrözi, hogy a szabályozó is teljes mértékben irányadónak ismeri el.

Ebből a szemszögből a BUBOR maximálisan be tudta tölteni az őt létrehozó Magyar Forex Társaság által elvárt szerepét. A budapesti referencia-ráta számos magyar jogszabályban megjelent a megalakulása óta. A LIBOR-botrány kirobbanásakor többek között ${ }^{53}$ az alábbi törvények, kormányrendeletek hivatkoztak a BUBOR-ra (a pontos hivatkozásokat a 8.1-es Melléklet tartalmazza):

\footnotetext{
${ }^{51}$ A treasury szaknyelvben az egyes területekre desk-ként hivatkoznak, mely angol kifejezés már a magyar nyelvben is meghonosodott. Pl. kötvény-desk vagy deviza-desk.

${ }^{52}$ ALM - Asset Liability Management. Az ALM trading területek kizárólag olyan ügyleteket (deal) tartalmaznak, melyek a banki könyvi nyitott pozíciók kockázatának zárását biztosítják (hedge). A magyar piacot tekintve ezen ügyletek volumene jóval magasabb és hosszabb lejáratúak, mint a kereskedési könyvi ügyletek.

${ }^{53}$ A dolgozatnak nem célja a teljes körü felsorolás, mindazonáltal a felhozott példák kiválóan alkalmasak a BUBOR széleskörü szerepének a szemléltetésére.
} 
a. 1996. évi CXII. törvény a hitelintézetekről és a pénzügyi vállalkozásokról (Hpt.) 201/B. §. (hatályos 2013.12.31-ig)

b. 2013. évi CCXXXVII. törvény a hitelintézetekről és a pénzügyi vállalkozásokról (új Hpt.) 280.§ (a hivatkozott paragrafus hatályos 2015. január 31-ig)

c. 2011. évi LXXV. törvény a devizakölcsönök törlesztési árfolyamának rögzítéséről és a lakóingatlanok kényszerértékesítésének rendjéről 4. §.

d. 2009. CLXII. törvény a fogyasztónak nyújtott hitelről (Fht.) 17/C. §. és 17/D. §. (a hivatkozott paragrafusok hatályosak 2015. február 1-töl)

e. 2009. évi IV. törvény a lakáscélú kölcsönökre vonatkozó állami kézfizetö kezességröl 2. §.

f. 2007. évi CVI. törvény az állami vagyonról 68 . §.

g. 399/2007 (XII.27.) Kormányrendelet a foglalkoztatói nyugdíjszolgáltató intézmények éves beszámoló készítési és könyvvezetési kötelezettségének sajátosságairól 7. §.

h. 215/2000. (XII. 11.) Korm. rendelet a befektetési alapok éves beszámoló készítési és könyvvezetési kötelezettségének sajátosságairól 7. §.

i. 250/2000 (XII. 24.) Kormányrendelet a hitelintézetek és a pénzügyi vállalkozások éves beszámoló készítési és könyvvezetési kötelezettségének sajátosságairól 14. §.

j. 251/2000. (XII. 24.) Kormányrendelet a befektetési vállalkozások éves beszámoló készítési és könyvvezetési kötelezettségének sajátosságairól 14. §.

k. 17/2010. (III. 4.) FVM rendelet a családi gazdálkodók által igénybe vehető átmeneti állami támogatásról 1. §.

1. 29/2009. (VI. 25.) KHEM rendelet a földgázpiaci egyetemes szolgáltatáshoz kapcsolódó árak képzéséről 6. §.

m. 19/2010. (XII. 3.) NFM rendelet az egyetemes szolgáltatók részére vételre felajánlott földgázforrás és a hazai termelésű földgáz mennyiségéről és áráról, valamint az igénybevételre jogosultak és kötelezettek köréről 4. §.

A felsorolásból is látható, hogy a BUBOR-jegyzés az élet rengeteg területére beépült, a devizakölcsönöktől kezdve az állami támogatásokon át a földgázpiaci árképzésekig. A fentiekből a legjelentősebbnek az első három hivatkozás (a., b. és c.,) tekinthető. A Hpt. alapján forintalapú jelzáloghitelek esetén a változó kamatozás esetén a törvény két típusú referencia-kamatláb alkalmazását engedi meg: a BUBOR-ét illetve az Államadósság Kezelő Központ (ÁKK) által rendszeresen közzétett állampapír átlaghozamot. Vagyis a jogszabályalkotó a BUBOR-t az ÁKK által kibocsátott értékkel egyenrangú referenciaértéknek ismerte el. Emellett az sem hagyható figyelmen kívül, hogy ezáltal a BUBOR hatóköre a bankközi piactól a teljes lakosságra is közvetlenül kiterjedt, és erre a szerepre a szabályozó a BUBOR-t megfelelőnek tartja. Kiemelendő, hogy a BUBOR szerepe a 
devizahiteles probléma során sem ingott meg, hiszen a gyűjtőszámlákról szóló 2011. évi LXXV. törvény is 3-havi BUBOR-t jelül meg alkalmazandó referencia-kamatlábként illetve a 2013-ban kiadott új Hpt. (2013. évi CCXXXVII. törvény) is megtartotta a BUBORhivatkozásokat.

Az e. és az f. hivatkozás az állami pénzügyi szerepvállalásába való beépülését mutatja. A BUBOR megjelenik többek között az állami garanciák és a pártfinanszírozás területén is. Az g., h., i. és j. hivatkozások a pénzpiaci szereplők kötelező beszámoló készítési folyamatába való integrációt szemléltetik. A tőzsdén kívüli kamatlábügyletek piaci értékének a meghatározásánál a szabályozó a BUBOR-t tekinti referencia-rátának.

Azonban a BUBOR nem kizárólag csak a banki és az állami finanszírozási ügyletekre van hatással. A k., l. és m. pontban említett rendeletekben a BUBOR közvetetten beépül az agrárpiaci és az energiapiaci szereplők életébe is.

\subsubsection{A fair bank törvény hatása a forint referencia-kamatlábra}

2015. február 1-től a fogyasztói kölcsönszerződésekre vonatkozó jogszabályok sokkal általánosabban közelítik meg a referencia-kamatlábat. A 2014. évi LXXVIII. a fogyasztónak nyújtott hitelről szóló 2009. évi CLXII. törvény és egyes kapcsolódó törvények módosítására vonatkozó ún. „fair bank” törvény eredményeképpen a hatályos Hpt.-ből kikerült a 280.§., és helyette a 2009. évi CLXII. a fogyasztónak nyújtott hitelröl szóló törvény 17/C. illetve 17/D. §-a szabályozza részletesen 2015 februárjától a referencia-kamatláb alapján árazódó fogyasztói hiteltermékeket, amelyek nem emelik ki külön a BUBOR-t, mint a forinttermékekre vonatkozó egyik választható referencia-kamatlábat. A fair bank törvény és a hatályos Hpt. alapján a referencia-kamatlábhoz kötött hiteltermékekre többek között az alábbiak vonatkoznak az alkalmazható referencia-kamatlábakra:

- Referencia-kamatláb: bármilyen alkalmazandó kamat számításának alapjául szolgáló, a nyilvánosság számára hozzáférhető mindenkori kamatláb, amelynek mértékére a hitelezőnek nincs ráhatása (Hpt. 6.§. (1) 93.);

- A referencia-kamatlábat az alkalmazásának feltételeivel együtt, közérthető magyarázattal ellátva kell bejelenteni, és annak közzétételéröl is ilyen módon kell gondoskodni (Fht. 17/D. §. (5) bekezdés);

- MNB honlapján közzétett (Fht. 17/C. §. (1) b. bekezdés); 
- MNB részére elözetesen bejelentett. $\mathrm{Az}$ MNB az alkalmazását határozatban elutasíthatja. (Fht. 17/D. §. (4) bekezdés);

- Amennyiben a referencia-kamatláb kialakítását meghatározó körülményekben bekövetkezett lényeges változás miatt a rendeltetésére alkalmatlanná válna, az MNB megtilthatja alkalmazását, és helyettesítő értéket írhat elő. (Fht. 17/D. §. (6) bekezdés).

A BUBOR múltja és felhasználási köre alapján teljes mértékben megfelel az új törvényi feltételeknek. Az MNB referencia-kamat elismerési jogkörének következően csökken a további alternatív benchmarkok megjelenési valószínüsége. Ez a jogkör azonban a kamatjegyzőket is fokozatosabb körültekintésre ösztönözheti, hiszen az MNB akár a BUBOR referencia-kamatlábként való alkalmazását is megtilthatja.

A BUBOR jövőbeli információtartalmával kapcsolatosan a fair bank törvény további kérdéseket vet fel. Az Fht.-re alapozva a jogalkotó részletesen meghatározza az intézmények kamatfelár, vagyis a hitelkamatláb és a referencia-kamatláb különbségének egyoldalú módosítási lehetőségeit. A dolgozat későbbi elemzéseiben rámutatok, hogy a BUBOR jegybanki alapkamathoz való konvergenciájával, egyes esetekben olyan piaci hatások sem jelennek meg a BUBOR szintjében, amelyek az intézmény forrásköltségét befolyásolják. Ilyen esetekben a mindenkori jogszabályi környezet függvénye, hogy ezen forrásköltség növekedést az intézmények a kamatfeláron keresztül tovább háríthatnak-e az ügyfelekre. Amennyiben nem, hosszú távon több kimenetel is lehetséges:

- megváltozhatnak a BUBOR-jegyzés tulajdonságai, az intézmények több piaci információt is megjeleníthetnek a jegyzésben;

- a jelenlegi jegyzési tartalom nem változik, ugyanakkor a hitelkínálati kamatfelárak megnövekedhetnek, hogy biztosan minden jövőbeni forrásköltség növekedést eredményező piaci esemény esetén megfelelő szintű jövedelmezőségi szintet biztosítsanak (egy további kérdés, hogy a piaci versenynek mekkora kamatfelár szükítő hatása lesz az adott termékek esetében);

- egy szélsőséges esetben akár más alternatív benchmark felé is elfordulhatnak az intézmények (ennek véleményem szerint jelenleg kicsi a valószínüsége, mivel nincs a piacon olyan helyettesítő referencia-érték, amely egyértelműen jobb választás lenne az intézmények számára). 
A felsorolt lehetőségekböl, melyik fog érvényesülni, pontosan megmondani nem lehet. Ennek vizsgálata 3-5 év múlva releváns elemzői kérdés lesz, amellyel érdemes és kell is foglalkozni. Kizárólag a kamatfelárak változásának elemzéséhez szintén jó pár évnyi tapasztalat szükséges. Ezeknél az elemzéseknél nagyon fontos, hogy a jogszabályi környezetben ne legyenek gyökeres változások, hiszen csak ekkor tekinthetünk a kamatfelárakra homogén (jogszabályi) körülmények között született döntések eredményeként. Annyi azonban kijelenthető az jogszabályi környezetnek köszönhetően, hogy a BUBOR a jövőben is számos elemzés alapja lesz. 


\section{A BUBOR-hoz köthető állományok és a BUBOR- jegyzések részletes statisztikai elemzése ${ }^{54}$}

A dolgozat statisztikai elemzési részéhez felhasznált adatok a BUBOR-piacot 2012. június 30-ig ölelik át. A kereskedési pozíciókat tükröző állományi adatok azonban csak 2009-től álltak rendelkezésemre. Ebből kifolyólag az elemzés egyes részeit csak a 2009-2012 közötti időszakra végeztem.

Az adatok záró 2012. június 30-i értéke szinte napra pontosan egybeesik a Barclays jelentés megjelenésével, mely rendkívüli gyorsasággal a világ minden referencia-kamatlábának, köztük a BUBOR-nak a piacára is kihatott. Mind az intézményi belső kontrollok felerösödése, mind a fokozottabb szabályozói jelenlét kihatott a jegyzést végző kereskedők viselkedésére. Sőt, az eltelt időszak alatt a BUBOR jegyzési szabályzata is megváltozott, így az új jegyzések eredményét érdemes elemzés szempontjából különválasztani. A dolgozatomnak nem része az a kérdéskör, hogy a botrány hatására milyen változások mutathatók ki statisztikailag jegyzésekben ${ }^{55}$.

Mindazonáltal már a szabályzat változásából is jelentős különbségek adódnak. A BUBORjegyzést végző intézmények körének leszűkülése is azt mutatja, hogy a BUBOR-piacon kevésbé aktív intézmények a LIBOR-botrány óta a jegyzéshez kapcsolódó reputációs kockázatokat sokkal magasabbnak ítélik meg, mint a jegyzésben való részvétel pozitív vonzatait. Ezért többen kivonultak a jegyzésből. A definíció is pontosabb lett, ezáltal szükül az intézmények közötti eltérő értelmezésből adódó jegyzéskülönbségek valószínűsége.

\subsection{BUBOR-ral kapcsolatos elemzések a LIBOR-botrány előttt}

A LIBOR botrány elött a BUBOR-ral kapcsolatos elemzések nem a jegyzések megbízhatóságára fókuszáltak, hanem arra a kérdéskörre, hogy vajon ebben a tágan megadott definícióban milyen információkat jelenítenek meg a jegyzést végző bankok és biztosítók.

Horváth-Krekó-Naszódi 2004-ben azt vizsgálta, hogy a BUBOR szintjének változása hogyan hat a lakossági és a vállalati hitelek kamatára, mivel a BUBOR-ra mint kiemelt referenciarátára tekintettek (Horváth-Krekó-Naszódi [2004]). A további tanulmányok megállapították,

\footnotetext{
${ }^{54}$ Az elemzéshez felhasznált adatok forrása: Pénzügyi Szervezetek Állami Felügyelete (közvetetten a Magyar Nemzeti Bank). Ezúton köszönöm a Felügyelet vezetőinek a hozzájárulását az adatok anonimizált felhasználásához. Az elemzés első formájában a Felügyelet honlapján került publikálásra (Fliszár [2013]).

${ }^{55}$ A kérdés megválaszolásához az újabb adatok nem álltak rendelkezésemre.
} 
hogy a három hónapos bankközi kamatláb alakulása a monetáris transzmisszió egyik kulcseleme (Vonnák [2006] és Ábel-Kóbor [2008]).

2007-ben a forint kamatswapszpred ${ }^{56}$ mozgatórugói között a BUBOR-értékek kiemelten szerepeltek. Csávás, Varga és Balogh tanulmányában (Csávás-Varga-Balogh [2007]) kimutatta, hogy a BUBOR-szpred ${ }^{57}$ előjele 3-éves szpred esetén pozitív, mely előjelet a BUBOR definíciójára vezetik vissza és nem arra a tényre, hogy a jegyző bank nemfizetési kockázata magasabb az állam nemfizetési kockázatánál, hiszen a magyar piacon többségében külföldi tulajdonú bankok tevékenykednek. A szerzők a fenti megállapításokon túl már ekkor előrevetítik a BUBOR szerepének csökkenését a magasabb referencia-kamatlábakkal szemben. 2009-ben azonban az MNB szemle hasábjain Pintér és Pulai megállapította, hogy a BUBOR-értékek a válság elmélyülése óta nem tükrözik a szereplők piaci várakozásait. A BUBOR elvesztette információtartalmát és más bankközi eszközök alkalmasabbak hozamgörbe becslésekre. (Pintér-Pulai [2009]).

A LIBOR-botrány egy új megközelítésre világított rá, hiszen ettől fogva a jegyzések valóságtartalmát, illetve a jegyzést végző intézmények viselkedését is vizsgálni kellett. A magyar adatok esetében ezt tovább nehezítette az a tény, hogy a BUBOR-piac az indulása óta leszükült, így a jegyzések gyakorlatilag egy fiktív értéket jelenítettek meg, mely alapvetően a jegybanki alapkamathoz és annak várakozásaihoz kapcsolódott. Sőt az intézmények kereskedési pozíciója sem alapvetően a BUBOR aktuális értékétől függött. Ennek következtében számos alkalommal előfordult, hogy a jegyzést végző kereskedő több napon keresztül nem változtatott a rögzített értéken. (Így egyes periódusokban egy „lépcsőzetes” jegyzés ${ }^{58}$ is kialakulhatott.) Ezért az idősorelemzési módszertanok alkalmazása jelentős akadályokba ütközne.

Dolgozatom során arra szeretnék rámutatni, hogy ilyen speciális esetekben a leíró statisztika és egyes keresztmetszeti módszertanok is a segítségünkre lehetnek.

\footnotetext{
${ }^{56}$ A kamatswap- és állampapírhozamok különbözete.

${ }_{58}^{57} 6$ hónapos BUBOR és 6 hónapos zérókupon hozam különbsége.

${ }^{58}$ Mivel egyes aktív kamatjegyző intézmények pozíció több napon keresztül nem változtak, és csak néhány kereskedési napon történt módosítás, a jegyzéseik görbéjének formája egy emelkedő és süllyedő lépcsőre kezdett hasonlítani egyes periódusokban.
} 


\subsection{BUBOR-bázisú állományi adatok}

\subsubsection{A BUBOR-hoz kapcsolódó hitel-betét állományok}

A BUBOR-jegyzést végző bankok ${ }^{59}$ állományi adatai alapján 2012. június 30-án 601 milliárd forint értékü betét (ebből 110 milliárd lakossági, 136 milliárd kis- és középvállalati $\left(\mathrm{SME}^{60}\right)$ és 355 milliárd vállalati) illetve 2479 milliárd forint értékű hitelállomány (ebből 345 milliárd lakossági, 638 milliárd kis- és középvállalati és 1496 milliárd vállalati) árazódott a BUBOR alapján. A betétállomány a 2007.12.31-i 520 milliárd forintos értékröl 2012.06.30-ra 602 milliárd forintra növekedett. A 2007-es állomány 2009.12.31-re közel 140 milliárd forinttal növekedett, mely 2012.06.30-án - a vállalati betétek csökkenésének következtében - 50 milliárd forinttal 602 milliárdra csökkent, ami a 2007.12.31-i 500 milliárdos szinthez képest 20\%-os növekedés.

4. táblázat: BUBOR-hoz kötött betét- illetve hitelállományok alakulása a BUBOR-jegyzésben résztvevő intézmények esetében 2007-2012

\begin{tabular}{|c|c|c|c|c|c|c|c|c|}
\hline & & & $2007 / 12$ & $2008 / 12$ & $2009 / 12$ & 2010/12 & 2011/12 & $2012 / 06$ \\
\hline \multirow{8}{*}{ 离 } & Lakosság & mrd HUF & 52 & 53 & 65 & 47 & 78 & 110 \\
\hline & & \% év/év & & $1,3 \%$ & $24,3 \%$ & $-28,4 \%$ & $67,5 \%$ & $40,9 \%$ \\
\hline & SME & mrd HUF & 70 & 80 & 85 & 130 & 132 & 136 \\
\hline & & $\%$ év/év & & $12,9 \%$ & $6,5 \%$ & $53,2 \%$ & $1,6 \%$ & $3,2 \%$ \\
\hline & Vállalat & mrd HUF & 398 & 379 & 511 & 424 & 437 & 356 \\
\hline & & \% év/év & & $-4,6 \%$ & $34,7 \%$ & $-17,0 \%$ & $3,1 \%$ & $-18,7 \%$ \\
\hline & Összesen & mrd HUF & 520 & 511 & 661 & 601 & 647 & 602 \\
\hline & & \% év/év & & $-1,7 \%$ & $29,3 \%$ & $-9,2 \%$ & $7,8 \%$ & $-7,0 \%$ \\
\hline \multirow{8}{*}{ 隶 } & Lakosság & mrd HUF & 25 & 9 & 13 & 108 & 214 & 345 \\
\hline & & \% év/év & & $-62,6 \%$ & $36,1 \%$ & $763,9 \%$ & $97,7 \%$ & $61,1 \%$ \\
\hline & SME & mrd HUF & 727 & 660 & 597 & 629 & 628 & 638 \\
\hline & & \% év/év & & $-9,3 \%$ & $-9,5 \%$ & $5,4 \%$ & $-0,1 \%$ & $1,6 \%$ \\
\hline & Vállalat & mrd HUF & 1859 & 1906 & 1793 & 1626 & 1468 & 1495 \\
\hline & & \% év/év & & $2,5 \%$ & $-5,9 \%$ & $-9,3 \%$ & $-9,7 \%$ & $1,9 \%$ \\
\hline & Összesen & mrd HUF & 2611 & 2575 & 2403 & 2363 & 2310 & 2479 \\
\hline & & \% év/év & & $-1,4 \%$ & $-6,7 \%$ & $-1,6 \%$ & $-2,2 \%$ & $7,3 \%$ \\
\hline
\end{tabular}

forrás: PSZÁF, saját szerkesztés

A BUBOR-alapú hitelállomány a 2007-2012 közötti periódusban 2300-2600 milliárdos sávban mozgott. Az állomány 60\%-át teszik ki a vállalati hitelek, melyek részesedése 2009

\footnotetext{
${ }^{59}$ Az állományi adatok a BUBOR jegyzésben 2012. június 30-ig bezárólag valaha is szerepet vállalt és 2012. június 30-án még müködő intézmények adatait tartalmazzák.

${ }^{60} \mathrm{SME}=$ small and medium enterprises
} 
végén a 75\%-ot is elérte a BUBOR-alapú hitelállományon belül. A részarány csökkenés a BUBOR-hoz árazott lakossági jelzáloghitel állomány növekedésének következménye. A BUBOR alapján árazódó lakossági jelzáloghitel állomány 2012.06.30-án meghaladta a 340 milliárd forintot. A növekedést az okozta, hogy az intézmények a forint jelzáloghitelek esetén jellemzően a BUBOR-t választották a Hpt.-ben ${ }^{61}$ előírt referencia-kamat mértékének.

1. ábra: BUBOR-hoz kötött betétállományok és súlyuk a teljes betétállományon belül 2007. december 2012. június (milliárd forint ill. \%) a BUBOR jegyzésében résztvevő intézmények állományi adatai alapján

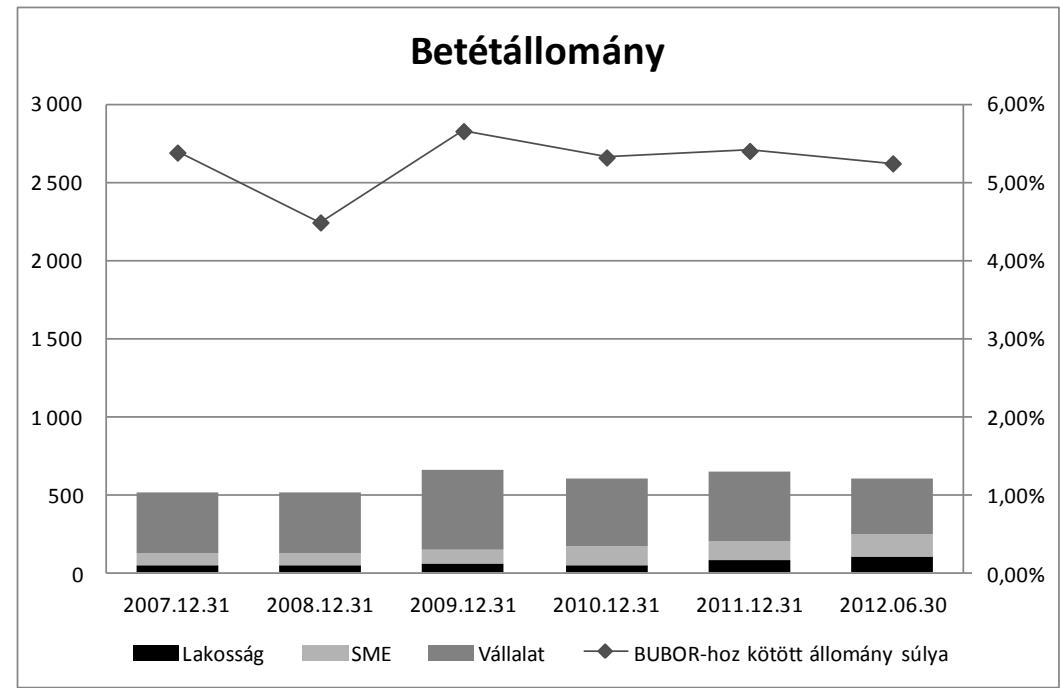

forrás: $M N B$, saját szerkesztés

2. ábra: BUBOR-hoz kötött hitelállományok és súlyuk a teljes hitelállományon belül 2007. december 2012. június (milliárd forint ill. \%) a BUBOR jegyzésében résztvevő intézmények állományi adatai alapján

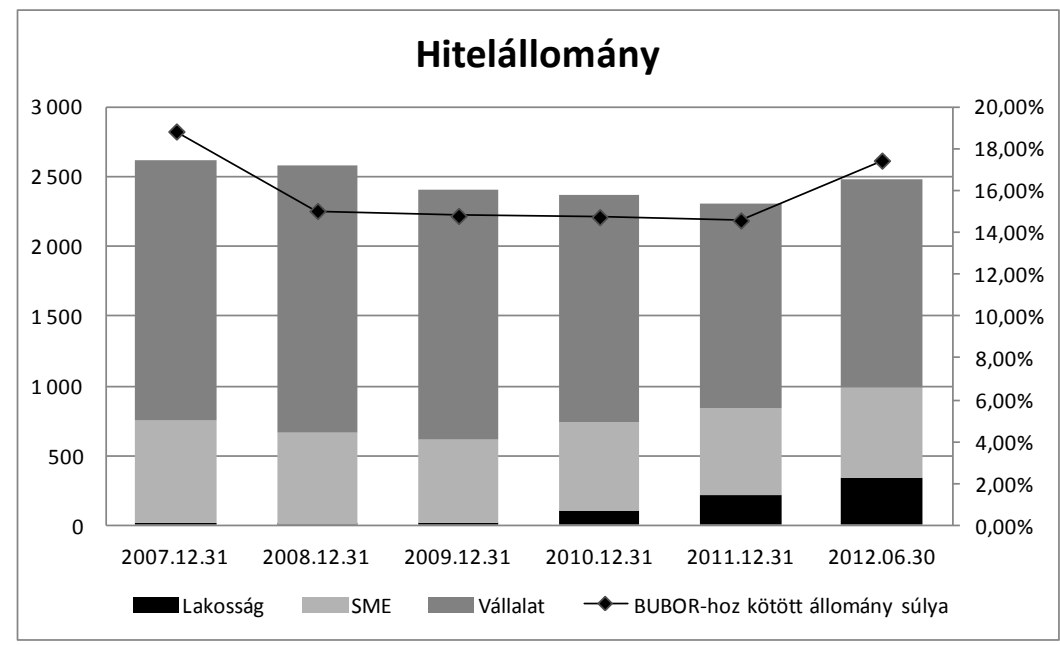

forrás: MNB, saját szerkesztés

\footnotetext{
${ }^{61}$ 1996. évi CXII. törvény (Hpt.) 210/B §
} 
A teljes betét- illetve hitelállományhoz viszonyítva a BUBOR alapján árazódó állományok egyik időpontban sem haladták meg a 6 illetve a 19\%-ot ${ }^{62}$. Amennyiben csak a forint állományokat tekintjük, a betétek aránya továbbra sem éri el a 8\%-ot, stabilan 7-7,5\% körül mozog. A hitelállomány súlya ezzel szemben sokkal jelentősebb. A vizsgált időszakban a 1518\%-körüli sávban mozgott, mely érték 2012 júniusára 17,44\% volt. A változásban jelentős szerepet játszott a végtörlesztés, melynek eredményeképpen a hitelállomány jelentősen összehúzódott. Ez az összehúzódási hatás kizárólag a devizahitel állományokat érintette, mely a forintállományok szektorbeli súlyát jelentősen megnövelte.

Érdemes külön megvizsgálni a BUBOR-hoz kötött jelzáloghitel állományok alakulását. A BUBOR alapján árazódó jelzáloghitelek állománya 2007 és 2012 között 68\%-kal növekedett, a 2007-es 376 milliárd forintnyi állomány 631 milliárdra nőtt. A jelentős növekedést a BUBOR alapján árazódó lakossági jelzáloghitel portfólió felépülése magyarázza, hiszen míg 2007-ben mindösszesen 2 milliárd forintnyi lakossági jelzáloghitel árazódott a BUBOR alapján, addig 2012 közepén már a lakossági rész elérte a 342 milliárd forintot. A devizaalapú jelzáloghitelek folyósításának megszünésével illetve a devizahitelt kiváltó forinthitelek révén alig két év alatt a forint alapú hitelek 7\%-át kitevő portfólió épült fel, mely a törvény adta lehetőségek alapján a BUBOR alapján árazódik át.

3. ábra: BUBOR alapján árazódó jelzáloghitelek állománya 2007. december - 2012. június (milliárd forint) a BUBOR jegyzésében résztvevő intézmények állományi adatai alapján

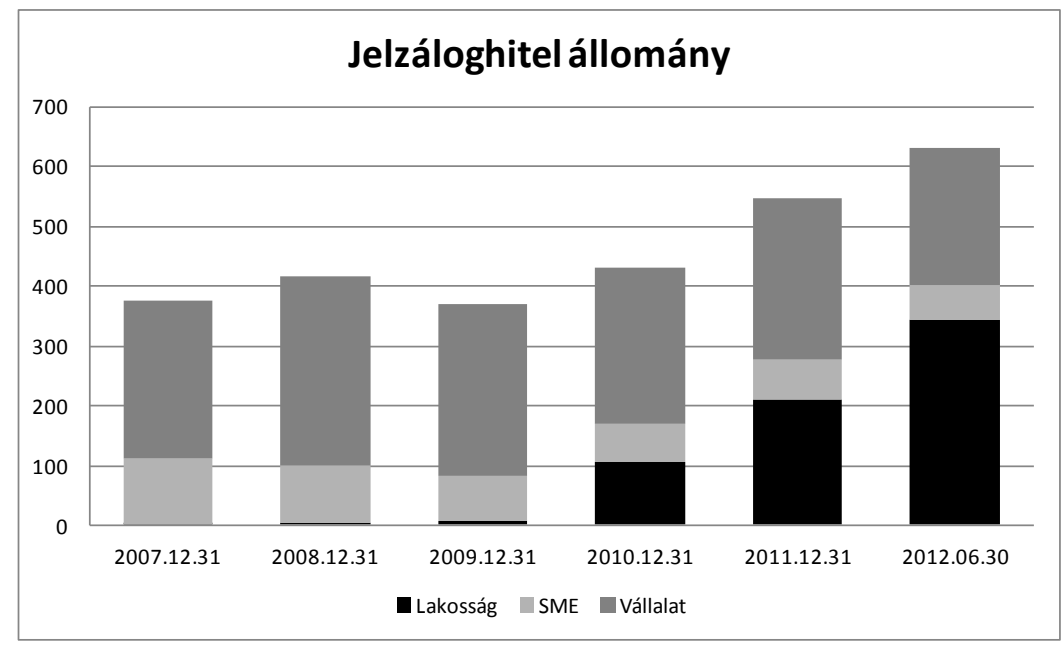

forrás: MNB, saját szerkesztés

Az állományi adatok bemutatása alapján elmondható, hogy bár a gazdasági válság bizonyos oldalról gyengítette a BUBOR pozícióját (a piac kiürül, a jegyzők száma csökken), a

\footnotetext{
${ }^{62}$ Az arányok meghatározásánál minden vizsgált időpontban a devizaállományok értékelésénél az aktuális árfolyamot vettük alapul. Az árfolyamhatás nem került kiszürésre.
} 
magyarországi devizahiteles problémára adott megoldások azonban tovább erősítették a budapesti bankközi kamatláb szerepét, hiszen a lakossági szektorban megnőtt a BUBOR-hoz köthető állományok súlya. A BUBOR alkalmazását a szabályozó a jogszabályi környezetbe is beemelte, mely alapján kijelenthető, hogy a piaci várakozásokat jól tükröző referenciaértéknek tekinti. A lakossági érintettség azonban további nyomást gyakorol a jegyzést végző bankok számára, hiszen bármilyen BUBOR-jegyzésben előforduló zavar mély társadalmi problémává válhat. Ennek elkerülése érdekében kiemelten fontos a transzparens, jól szabályozott és ellenőrzött jegyzési folyamat kialakítása és fenntartása.

Ennél a ténynél azonban amellett sem szabad elmenni, a lakosság érdeke is, hogy a budapesti forint referencia-kamat jegyzése fennmaradjon, és ne kerüljön át Londonba vagy Frankfurtba, hiszen ez utóbbi esetben olyan intézmények határozhatnák meg a forint irányadó bankközi rátáját, melyek portfóliójában egyáltalán nincsenek is lakossági ügyletek, hanem kizárólag a kereskedési könyvükben tartanak forint hiteleket. Ezen intézményeket nem érintené a társadalmi nyomás, mivel a lakosság fizetőképességének változása nincs hatással a jövedelmezőségükre, így kevesebb manipulációt elutasító ösztönzővel rendelkeznek.

\subsubsection{Intézményi szintü, a BUBOR-hoz köthető derivatív pozíciók}

Elemezve az intézmények 2009. január és 2012. június közötti 3 illetve 6 havi referenciakamathoz kötött forint nettó FRA ${ }^{63}$ (forward rate aggreement), IRS ${ }^{64}$ (interest rate swap) és $\mathrm{CIRS}^{65}$ (cross-currency interest rate swap) pozícióinak alakulását ${ }^{66}$, a rendelkezésre álló adatok alapján megállapítható, hogy a piacot alapvetően hat-hét intézmény tevékenysége befolyásolja. Azonban ezen intézmények közül is mindösszesen kettő esetében fordult elő a 3 havi nettó pozíciók esetén, hogy a nettó pozíció mérete meghaladta volna a +/- 500 milliárd forintos értéket. A 6 havi pozíciók esetén 2012-ben mindösszesen egy intézmény esetében fordult ez elő.

\footnotetext{
${ }^{63}$ Definíciót lásd 8.7. Melléklet.

${ }^{64}$ Definíciót lásd 8.7. Melléklet.

${ }^{65}$ Definíciót lásd 8.7. Melléklet.

${ }^{66}$ A statisztikai elemzés során az összesített 3 illetve 6 havi nettó pozíciók kerültek felhasználásra.
} 
4. ábra: A 3 havi referencia-kamathoz kötött nettó pozíciók (milliárd forint) alakulása a legjelentősebb piaci szereplők esetén 2009. január - 2012. június

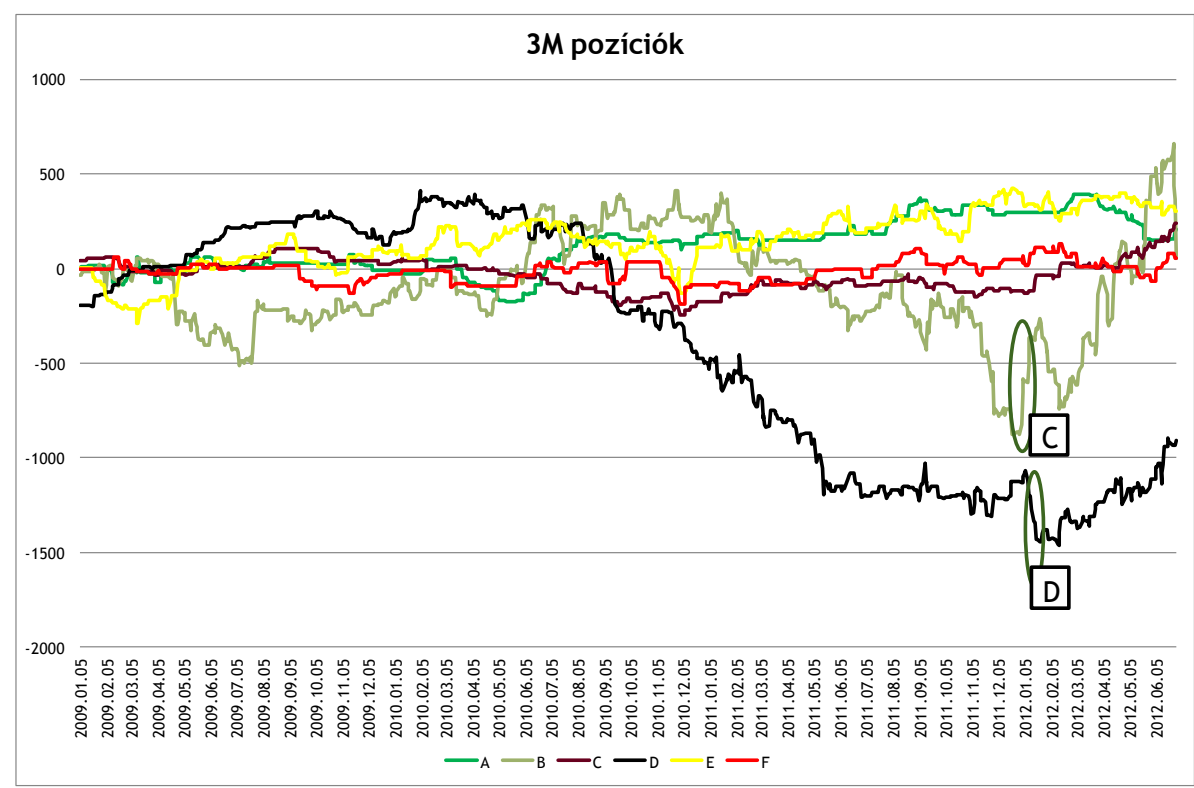

forrás: $M N B$, saját szerkesztés

5. ábra: A 6 havi referencia-kamathoz kötött nettó pozíciók alakulása (milliárd forint) a legjelentősebb piaci szereplők esetén 2009. január - 2012. június

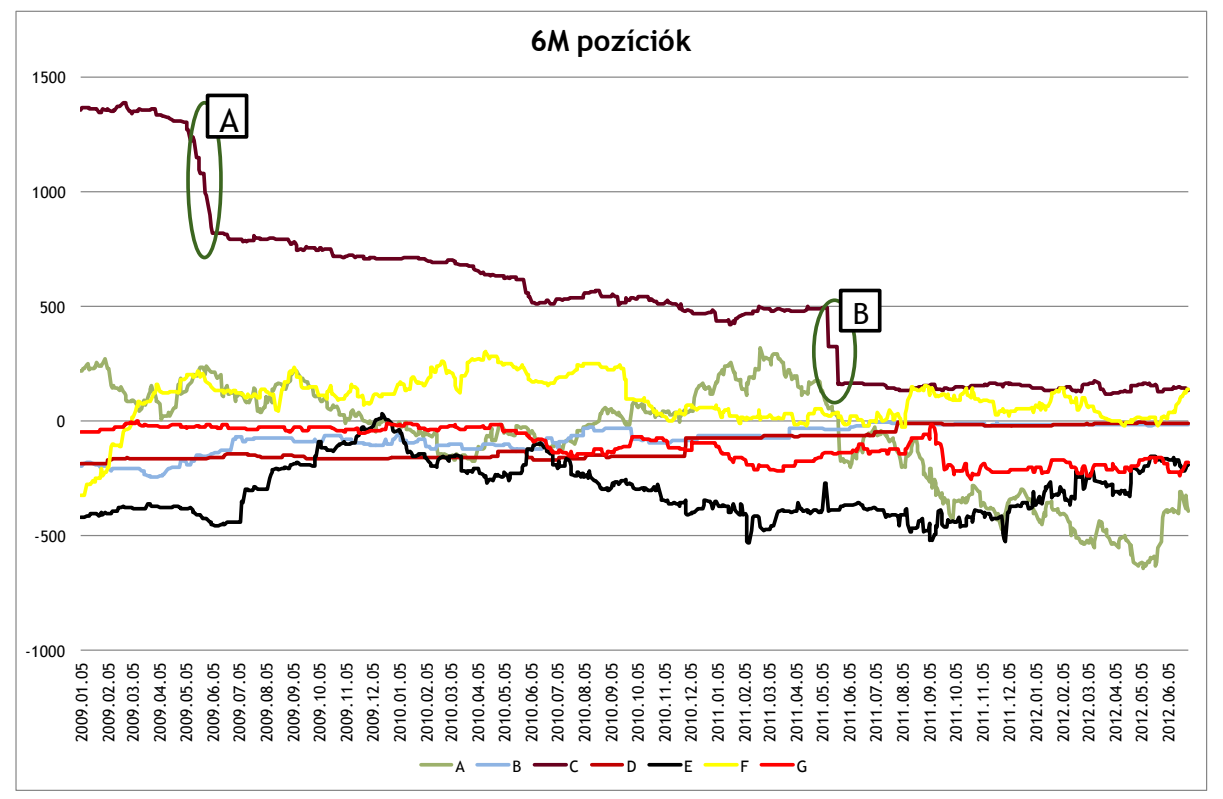

forrás: $M N B$, saját szerkesztés

Fontos hangsúlyozni, hogy a pozíciót elsődlegesen a devizaforrást biztosító CIRS ügyletek változása befolyásolja mind a 3, mind a 6 havi BUBOR-hoz kötött nettó pozíciók esetén. Az IRS ügyletekből származó nettó pozíciók mértéke szignifikánsan alacsonyabb, míg az FRAkből származó pozíciók hatása szinte marginálisnak tekinthető. (Az FRA ügyletek volumene a BUBOR-hoz kötött pozíciók között alacsony.) 
A nettó nyitott pozíciók nagysága intézményenként mindkét lejárati időszak (tenor) esetén a +/- 500 milliárd forintos sávban mozgott. Ebből a sávból csak három piaci szereplö lépett ki a vizsgált időszakban. Amennyiben a 3 legnagyobb kitettséggel rendelkező piaci szereplőtől eltekintünk, egy intézmény nettó pozíciója sem haladta meg 2011 nyara óta a +/- 200 milliárd forintot a két vizsgált tenorban.

A részletes elemzésnél érdemes figyelembe venni a nettó pozíciók hirtelen nagymértékü elmozdulását. Ez arra utal, hogy az adott intézménynek a vonatkozó kereskedési napon nagy értékü lejárata volt, melynek záró értékére kihatott az aznapi BUBOR. Egy 100 milliárdos lejárat esetén pár bázispontos elmozdulás is jelentős nyereséget vagy veszteséget tud generálni az intézmény számára. Amennyiben az intézmény a BUBOR jegyzésénél a szabályzattal ellentétesen figyelembe venné a lejáró pozícióját, az egyedi jegyzéseinél számára kedvező irányú elmozdulást valósítana meg. A következő fejezetben az ábrákon jelzett eseteket vizsgálom meg részletesen.

\subsubsection{A BUBOR-hoz köthető derivatív pozíciók és a jegyzések kapcsolata}

Az elemzés során négy jelentős nettó pozíció változásával járó (a 4. és 5. ábrán jelölt) intézményi jegyzést vizsgáltam meg, melyek eredményeit az 5. táblázat tartalmazza. Az elemzésnél egy +/-15 bázispontos elmozdulást átlagos sávnak tekintettem, mivel a nyesésen alapuló BUBOR módszertanban ilyen kismértékű alul- vagy felüljegyzés nem képes érdemben befolyásolni a BUBOR szintjét, illetve a jegyzőnek sem garantálja a jegyzésének kinn- vagy bennmaradását, amennyiben korábban nem jegyzett szélsőséges értéket.

\section{5. táblázat: Jelentősebb nettó pozícióváltozásokhoz kapcsolódó jegyzések vizsgálata}

\begin{tabular}{lll}
\hline & Dátum & Leírás \\
\hline A & 2009. május & $\begin{array}{l}\text { A bank jegyzése az átlagos jegyzéshez képest }+/-15 \text { bázispontos sávon belül } \\
\text { maradt. Nem jegyzett kiugró értéket. }\end{array}$ \\
B & 2011. május & $\begin{array}{l}\text { A bank jegyzése az átlagos jegyzéshez képest +/- } 15 \text { bázispontos sávon belül } \\
\text { maradt. Nem jegyzett kiugró értéket. }\end{array}$ \\
\hline
\end{tabular}




\begin{tabular}{|c|c|c|}
\hline & 2011. november & $\begin{array}{l}\text { A vizsgált időszakban a Moody’s leminősítette Magyarországot befektetésre } \\
\text { nem ajánlott kategóriába, illetve a Magyar Nemzeti Bank } 50 \text { bázisponttal } \\
\text { emelte az alapkamatot. A bank a leminősítést követőn a benchmarkoknál } \\
\text { magasabb szinten jegyezte az offert, azt a piaci véleményét fejezve ki, hogy } \\
\text { az adott körülmények között a likviditási prémiumnak magasabbnak kell } \\
\text { lennie. A piaci várakozásoktól eltérő viselkedés nem tapasztalható. }\end{array}$ \\
\hline $\mathrm{D}$ & 2012. január & $\begin{array}{l}\text { A kérdéses időszakban az EUR árfolyam történelmi mélypontot ért el. A } \\
\text { swapgörbe a bizonytalan piaci környezetben jelentősen elmozdult. A bank a } \\
\text { jegyzésében a többi intézményhez képest jobban érvényesítette a piaci } \\
\text { várakozásokat. A piaci várakozásoktól eltérő viselkedés nem tapasztalható. }\end{array}$ \\
\hline
\end{tabular}

A kiválasztott négy valós eset tekinthető a 2009 - 2012 közötti időszakban a BUBORjegyzésben résztvevő intézmények nettó pozícióváltásai közül a legnagyobb volumenü elmozdulásnak. Az összes többi vizsgált kereskedési napon az aktív kamatjegyző intézmények abszolút értékủ nettó pozícióváltozásai ennél alacsonyabbak voltak, vagyis az intézmények alacsonyabb manipulálásra ösztönző hatással rendelkeztek ezeken a napokon.

A részletesebb vizsgálatból megállapítható, hogy a BUBOR-hoz köthető derivatív pozíciók változásai nem mutatnak kapcsolatot a jegyzésekkel, manipulációra utaló jelek nem tapasztalhatók. A nagyobb piaci szereplők turbulens piaci körülmények között a jegyzésben megjelenítik a piaci értékítéletűket, normál piaci körülmények között a jegyzést nem befolyásolják a saját pozíciók változásai.

\subsection{BUBOR számítási módszertana és egyedi jegyzések}

\subsubsection{A BUBOR-jegyzés módszertana}

A 2004. január 27. - 2012. június 30. közötti időszakban 21 intézmény vett részt a BUBORjegyzésben aktív kamatjegyzőként.

A BUBOR mint referencia-kamat kialakításánál - az intézmények részvétele a LIBOR-hoz hasonlóan önkéntes - nem minden intézmény, hanem a legnagyobb piaci aktivitással rendelkező 16 adatszolgáltató által jegyzett értéket vettek figyelembe, melyek közül a legkisebb illetve a legnagyobb négy értéket vágták le (nyesés, trimmelés), vagyis egy adott nap referencia-értékét a középső nyolc jegyzés egyszerü számtani átlaga adja. Sajnos 
napjainkban a fenti megállapítás már nem állja meg a helyét. Nagyrészt a LIBOR-botránynak köszönhetően az önkéntes jegyzők száma jelentősen lecsökkent. 2014 februárjától már mindösszesen csak 10 bank jegyzi a BUBOR-t, és a jegyzések közül a két-két legmagasabb és legalacsonyabb értéket nyesik le. 2014 augusztusától a jegyzők szerepe tovább, 9-re csökkent. (A BUBOR-jegyzés főbb paramétereinek változását a 3. táblázat foglalja össze.)

A nyesett átlagoláson alapuló módszertan csökkenti a jegyzés manipulálhatóságát, ugyanakkor a jegyzési piacon lévő kis létszámú szereplő miatt tartósan nem fenntartható. 2012 folyamán négy intézmény jelezte, hogy a továbbiakban nem kíván, illetve nem tud részt venni a jegyzési folyamatban. Amennyiben a jegyző intézmények száma további kettővel csökkenne, a napi érvényes referencia-kamat értéke mindösszesen a jelentett értékek egyharmada alapján adódott volna (12 jegyzésből csak a középső 4-et vették volna figyelembe). A jegyzés megbízhatóságának érdekében az intézmények részvétele kulcskérdésnek tekinthető, ugyanis a jelenlegi tendencia folytatódása esetén csak a számítási folyamat gyengítésével - kevesebb szélsőérték elhagyásával - lehet a referencia-kamatot fenntartani, ami azt eredményezné, hogy adott esetben már 2-3 szélsőséges véleménnyel rendelkező intézmény is több tíz bázispontos elmozdulást tud elöidézni a referencia-kamat értékében. Ezt a változást követte le a Magyar Forex Társaság a hivatalos BUBOR-szabályzat módosításával. Az új szabályzat a nyesés mértékét a referencia-kamatot jegyző intézmények számához köti. (Bővebben lásd a BUBOR definíció c. fejezetben.)

\section{A nyesés mértékének szerepe a BUBOR számításában egy számpéldán keresztül}

A továbbiakban a 2012. január 6-i 3 havi valós BUBOR-jegyzéseken szemléltetem a fent említett problémát. Kiindulásnak a 2012. június 30-án érvényes számítási módszertant tekintem, mely szerint tenoronként a 16 jegyzésből a négy-négy legmagasabb illetve legalacsonyabb kerül elhagyásra.

2012. január 6-án a 16 jegyző bank 3 havi BUBOR-jegyzései alapján 7,58-as 3 havi BUBORérték került rögzítésre. A legalacsonyabb jegyzés 7,25, a legmagasabb 8,50 volt. A jegyzések nyesés nélküli átlaga 7,65, szórásuk 33 bázispont. A nyesés utáni szórás 12 bázispontra csökkent. Három intézmény jegyzett 8,00 vagy a feletti értéket, melyek legalább 25 bázisponttal meghaladják a legmagasabb átlagolásban maradt értéktől (7,75). Az alulról nyesett értékek legfeljebb 15 bázisponttal maradnak el a legalacsonyabb, a jegyzésben még bent maradó értéktől $(7,40)$. Ez alapján elmondható, hogy a felfelé torzítás nagyobb, melyet a nyesés a szórások változásával együtt kezel. Mindazonáltal mivel 16 intézmény volt a 
jegyzésben két, 8,00 feletti jegyzés sem képes eltorzítani a teljes átlagot $(7,65)$, mely mindösszesen 7 bázisponttal magasabb mint a végső 3 havi BUBOR.

6. táblázat: 2012. január 6-i 3 havi BUBOR-jegyzések és az intézményi jegyzések néhány leíró statisztikája

\begin{tabular}{|cc|c|}
\hline \multicolumn{3}{|c|}{2012.01 .06} \\
Intézmény & 3M BUBOR & \\
\hline A & 7,25 & Átlag \\
B & 7,30 & 7,65 \\
C & 7,35 & Szórás \\
D & 7,35 & 0,33 \\
\hline E & 7,40 & \\
F & 7,45 & \\
G & 7,50 & \\
H & 7,50 & \\
I & 7,58 & 3M BUBOR \\
J & 7,60 & $\mathbf{7 , 5 8}$ \\
K & 7,70 & Nyesett értéke szórása \\
L & 7,75 & 0,12 \\
M & 7,75 & \\
\hline N & 7,80 & \\
O & 8,00 & \\
P & 8,25 & \\
Q & 8,50 & \\
\hline
\end{tabular}

forrás: MNB, saját szerkesztés

Az elemzés során négy különböző nyesési eljárást vizsgáltam meg:

a) 2012. júniusi aktuális módszertan;

b) a két további intézmény átlagos jegyzésének elhagyása (kamatjegyző intézmények száma 14-re csökken), nyesés 3-3 legalacsonyabb illetve legmagasabb érték;

c) még további két - átlag körüli értéket jelentő - intézmény elhagyása (kamatjegyző intézmények száma 12-re csökken), nyesés 2-2 legalacsonyabb illetve legmagasabb érték;

d) legalacsonyabb négy értéket jegyző intézmény elhagyása (kamatjegyző intézmények száma 12), nyesés 2-2 legalacsonyabb illetve legmagasabb érték, és három intézmény a napi legmagasabb, 8,50-es értéket jegyzi.

A fenti feltételek mellett a BUBOR-értékek rendre: 7,58; 7,59; 7,64 és 7,74. 
7. táblázat: Példa a BUBOR-számítás érzékenységére - az egyes szcenáriókban alkalmazott 3 havi BUBOR-jegyzések

\begin{tabular}{|c|c|c|c|c|}
\hline \multirow{2}{*}{ Intézmény } & \multicolumn{4}{|c|}{ 3M BUBOR jegyzés ek } \\
\hline A & a) & b) & c) \\
B & 7,25 & 7,25 & 7,25 & 7,40 \\
C & 7,30 & 7,30 & 7,30 & 7,45 \\
\cline { 5 - 5 } D & 7,35 & 7,35 & 7,35 & 7,50 \\
E & 7,35 & 7,35 & 7,40 & 7,50 \\
\cline { 2 - 2 } F & 7,40 & 7,40 & 7,45 & 7,58 \\
G & 7,45 & 7,45 & 7,60 & 7,60 \\
H & 7,50 & 7,50 & 7,70 & 7,70 \\
I & 7,50 & 7,60 & 7,75 & 7,75 \\
J & 7,58 & 7,70 & 7,75 & 7,75 \\
K & 7,60 & 7,75 & 7,80 & 7,80 \\
L & 7,70 & 7,75 & 8,00 & 8,50 \\
M & 7,75 & 7,80 & 8,25 & 8,50 \\
N & 7,75 & 8,00 & 8,50 & 8,50 \\
O & 7,80 & 8,25 & & \\
P & 8,00 & 8,50 & & \\
Q & 8,25 & & & \\
\hline
\end{tabular}

forrás: MNB, saját szerkesztés

8. táblázat: Példa a BUBOR-számítás érzékenységére

\begin{tabular}{cccc}
\hline Verzió & BUBOR & Figyelembe vett értékek szórása & Jelentő intézmények száma \\
\hline a & 7,58 & 0,12 & 16 \\
b & 7,59 & 0,16 & 14 \\
c & 7,64 & 0,20 & 12 \\
d & 7,74 & 0,29 & 12 \\
\hline
\end{tabular}

forrás: $M N B$, saját szerkesztés

Amennyiben átlagos értéket jegyző intézmények vonulnak ki a fixing folyamatból, a nyesés mértéke követi a jegyzői kör szükülését, és nem nő meg a szélsőséges jegyzések súlya („,b” és „c" eset), a BUBOR minimálisan mozdul el a 2012-ben érvényes számítási módszertan alapján adódó szintről. Két kamatjegyző intézmény kiesésével mindösszesen egy bázisponttal, míg négy kamatjegyző kiesése esetén hat bázisponttal mozdulna el a referencia-kamat szintje. Ugyanakkor könnyen látható, hogy bár a „c” esetben a BUBOR-érték mindösszesen öt bázisponttal emelkedett, a figyelembe vett érték szórása közel 60\%-kal növekedett. Ez azt jelenti, hogy az árjegyzők számának csökkenésével a szélsőséges vélemények sokkal könnyebben teret kapnak a BUBOR-érték meghatározásakor. Ebből következően a 
későbbiekben is fontos szempont, hogy a piac méretéhez képest a lehető legtöbb intézmény véleménye jelenjen meg a BUBOR-értékében. Ezt a megállapítást támasztja alá a „d” eset is, mikor az intézmények száma szintén 12-re csökken, és több szélsőséges érték is megjelenik. Ekkor a nyesés utáni szórás tovább növekszik, 29 bázispontra, ami majdnem 2,5-szerese a kezdeti értéknek. A BUBOR pedig 7,74-re emelkedne, mely az eredeti értékhez képest 16 bázispontos elmozdulás, ami adott esetben jelentős haszonnal kecsegtethet, így erősebben ösztönöz manipulációra.

12 kamatjegyző esetén már három intézmény kooperációja/kartelle elégséges ahhoz, hogy egy szélsőséges jegyzés a nyesés után is az átlagolásban maradhasson, mely a korábbi öthöz képest jelentős csökkenés. Emellett fontos hangsúlyozni, hogy a BUBOR egyfajta szektorszintű átlagos kamatszintet jelenít meg, az intézmények számának csökkenése magának a definíciónak is megkérdőjelezné az érvényességét.

A nyesés szerepe a BUBOR-érték robosztusságánál kiemelten fontos, ugyanis az alsó és a felső 25\% elhagyása jelentősen csökkenti a manipuláció kockázatát. Azonban a jelenlegi BUBOR számítási módszertan szerint az elhagyandó jegyzések száma rögzített. Így az aktív kamatjegyző intézmények számának a csökkenésével a nyesés következtében jelentősen szükülhet a referencia-értéket ténylegesen meghatározó intézmények száma. A BUBOR transzparenciájának megőrzése érdekében fontos, hogy a jegyző intézmények számának csökkenésétől független legyen a nyesés aránya.

Ezért is fontos hangsúlyozni, hogy az intézményeknek reputációs érdeke is, hogy a jegyzésben részt vegyenek, és ne csak egy külső adottságként tekintsenek a hazai fizetőeszköz referencia-kamatára. Lényeges, hogy e tény hangsúlyozásával is ösztönözve legyenek a jegyzésben való további részvételre.

\subsubsection{A BUBOR-jegyzések adatminősége 2012. június 30-ig}

Az aktív kamatjegyző intézmények által jelentett O/N, 1, 3 és 6 havi BUBOR-értékek idősora és a Magyar Forex Társaság BUBOR számítási útmutatója alapján újra elvégeztem a BUBOR számítását, mely alapján az alábbi hibás értékeket azonosítottam a rögzített BUBOR idősorban:

- 2010. november 15. - 2011. január 6. közötti időszakban az O/N BUBOR-értékeknél a havi értékeket tárolták el, a jelentett értékekből adódó tényleges BUBOR-érték helyett; 
6. ábra: Az O/N és 1 havi BUBOR-értékek (\%) historikus idősora 2010. október - 2011. február

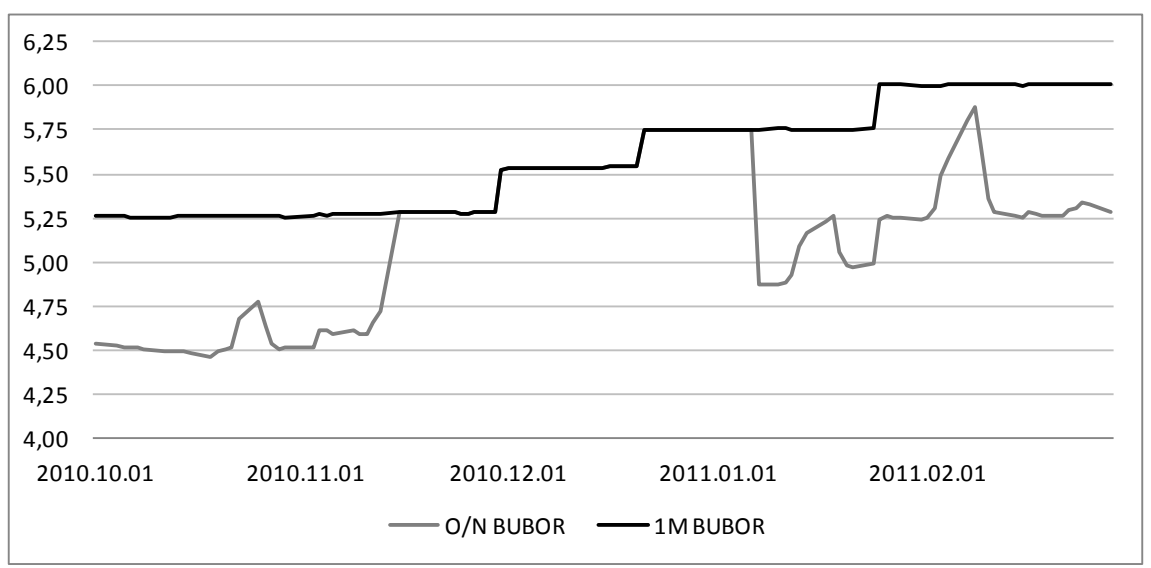

forrás: MNB, saját szerkesztés

- A 2004.10.19-i 3 havi BUBOR téves, a valós érték 1\%-ponttal eltér

Megjegyzendő, hogy a szokásos információs csatornákon (Reuters, Bloomberg terminál) csak a napi jelentett értékek találhatók meg, historikus lekérdezésre lehetőség nincsen.

Emellett megállapítható, hogy az intézményi szintü letárolt 1, 3 és 6 havi jegyzések között a 2005.01.01-2012.06.30-i periódusra vonatkozóan megközelítőleg 25 hibás jegyzés található. (A későbbi elemzések során a korrigált értékeket vettem figyelembe.) Az itt említett esetek nyilvánvaló egyedi szintü rögzítési hibák ${ }^{67}$ (elütések, más referencia-adatok rögzítése), melyek a megfelelő minőségű belső és külső kontrollfolyamatok hiányára utalnak, és a minimálisan elvárt négy-szem elv teljeskörüségét is megkérdőjelezik.

Az adattisztítás során felfedezett több nyilvánvalóan téves jegyzés a korábbi külső és belső kontrollfolyamatok nem megfelelő minőségére utal. A jegyzés megbízhatóságának erősítése érdekében fontos mind a belső, mind a külső kontrollfolyamatok javítása.

\subsubsection{A napi jegyzések szórása}

A BUBOR-definícióból kiindulva, amennyiben egy tökéletesen müködő piacon határozná meg egy aktív kamatjegyző a referencia-kamat szintjét, a jegyzéseknek bizonyos fokú diverzifikációt kellene mutatniuk. Ennek oka, hogy a piacon nincsen két egyforma intézmény, és a különbségeik az árazásban is meg kell mutatkozzanak. Amennyiben a napi jegyzések szórása nagyon alacsony az két dologra utalhat:

\footnotetext{
${ }^{67}$ Például egy intézmény 2008.07.16-án 5,60-on 6 havi BUBOR-t jegyzett, ugyanakkor az előző kereskedési nap 8,65, a következő kereskedési nap 8,60-at. Az adatok alapján egyértelmü, hogy elütés történt (8,60 helyett 5,60 került rögzítésre a rendszerben). Vagy egy másik intézmény esetén 2010.05.13-án a swap görbe az értékei kerültek jegyzésre minden tenor esetén.
} 
- az intézmények ugyanúgy értékelik egymást, vagyis homogén piaci szereplöket feltételeznek;

- nincsen valós/vagy csak minimális piaca van a mögöttes terméknek és egy elméleti definíció alapján határozódnak meg az értékek.

Az első eset nyilvánvalóan kizárható, hiszen a magyar piacon az aktív kamatjegyző intézmények nem homogének. Találhatók köztük éppúgy a nagy lakossági bankok mint kisebb fióktelepek vagy pénzügyi vállalkozások. (2012 júniusára vonatkozó állítás. 2014-re az aktív kamatjegyző intézmények száma 16-ról 10-re csökkent.) A bankszektor jelentős része külföldi tulajdonban van, és egy magyarországi leányvállalat megítélését az anyavállalat pozíciója is befolyásolja. Vagyis fennáll a heterogenitás.

7. ábra: 3 és 6 havi BUBOR napi jegyzések szórásának idősora 2006. január - 2012. június

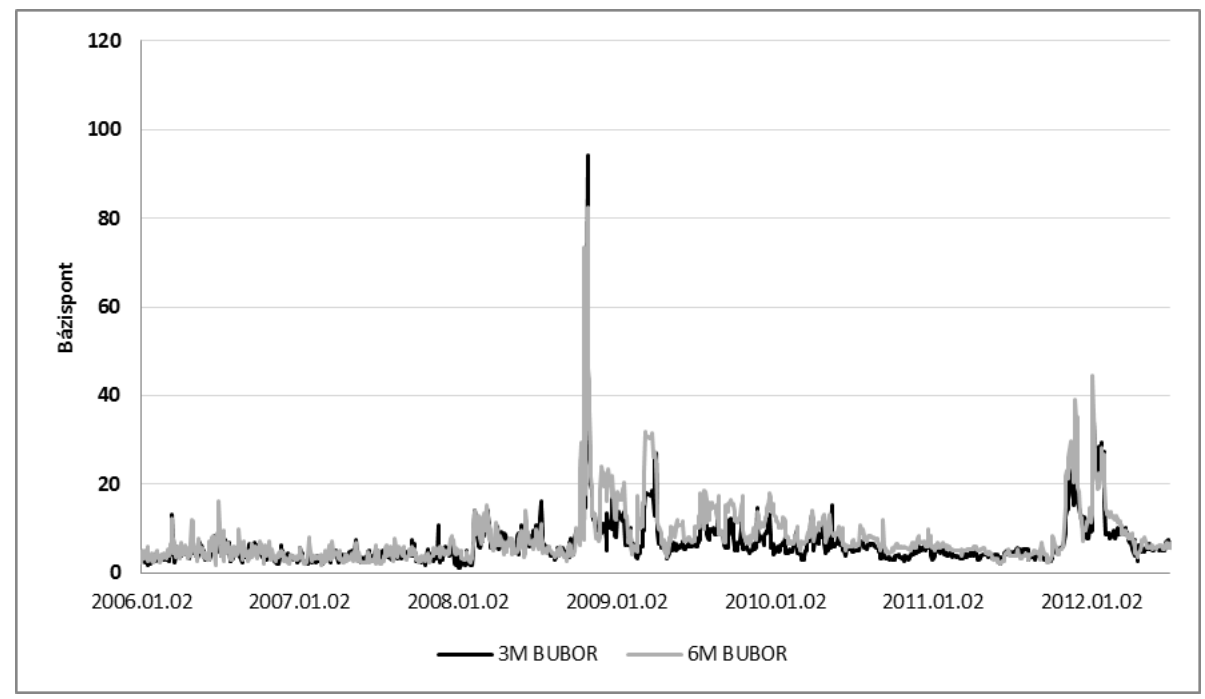

forrás: $M N B$, saját szerkesztés

A 7. ábrán látható, hogy a kereskedési napok döntő többségén a 16 aktív kamatjegyző intézmény által leadott BUBOR-jegyzés szórása mind a 3, mind a 6 havi tenorban a 20 bázispontos sávon belül marad. A vizsgált időszakban a kereskedési napok 87,9\% illetve 77,9\%-án a 10 bázispontot sem éri el. 20 bázispont feletti értékek csak a legturbulensebb piaci időszakokban fordultak elő. Az alacsony szórások alátámasztják ezt az elméleti definíciós esetet. Ebből a szempontból a 2008-es törés vizsgálatának nincs relevanciája, hiszen a jegyzést végző intézményekre már korábban is nyomás nehezedett a piac müködési problémáinak szemszögéből. Ezt támasztja alá az a fentebb említett tény is, hogy már 2002ben megszüntetésre került az üzletkötési kötelezettség elsődlegesen az intézmények közötti limitproblémák miatt, vagyis a bankközi piac szereplői a referencia-kamat mögöttes 
termékére nem elsődleges termékként tekintettek és sok esetben a konzervatív limitstruktúrájuk is gátolta a piac bővülését.

A nyesett jegyzések, vagyis a referencia-kamatot eredményező átlagolt értékek szórása még stabilabb képet mutat. A 2006. január - 2012. június közötti időszakban mind az 1, mind a 3 havi jegyzések esetében mindösszesen egyetlen kereskedési nap haladta meg a szórás a 13 bázispontos értéket. Ezeken a kereskedési napokon a relatív szórás a 0,02-es értéket sem haladta meg. A 6 havi jegyzések esetében a nyesett értékek szórása 17 kereskedési nap haladta meg a 10 bázispontot, azonban még ez is mindösszesen a vizsgált kereskedési napok 0,8\%-a. Vagyis a 6 hónapos BUBOR esetében megközelítőleg 130 kereskedési naponta ( félévente) következik be olyan jegyzés, mikor a nyesett értékek szórása meghaladja a 10 bázispontot.

8. ábra: Az 1 havi BUBOR-jegyzések nyesés utáni szórásának historikus idősora 2006. január - 2012. június

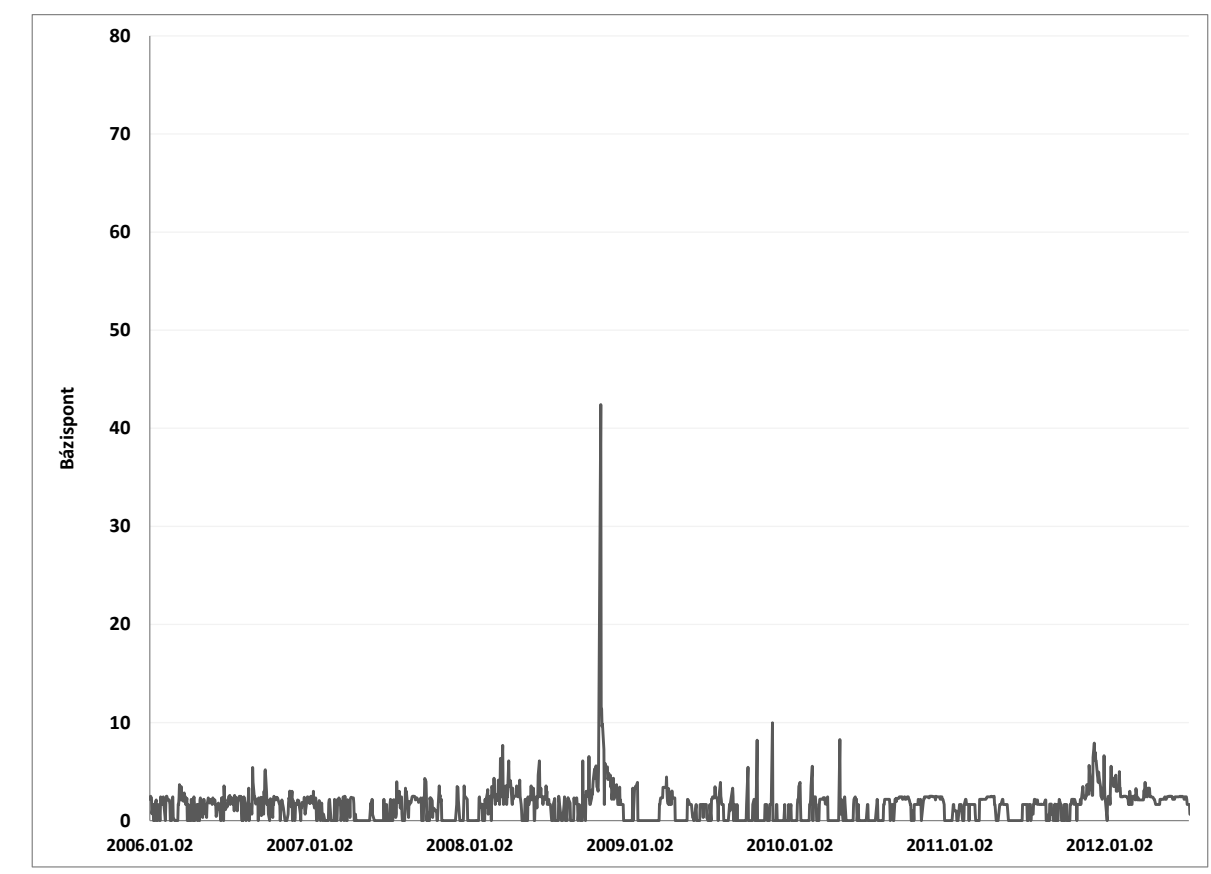

forrás: MNB, saját szerkesztés 
9. ábra: A 3 havi BUBOR-jegyzések nyesés utáni szórásának historikus idősora 2006. január - 2012. június

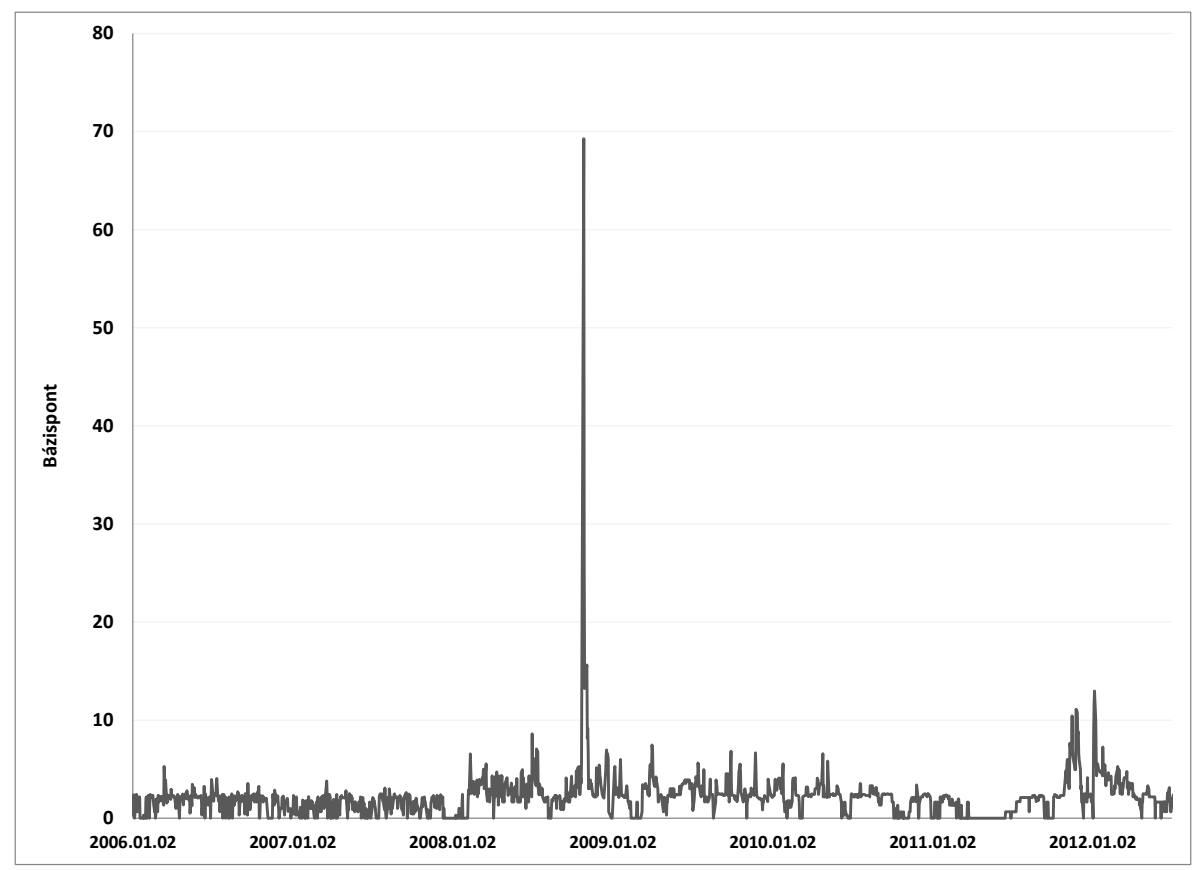

forrás: $M N B$, saját szerkesztés

10. ábra: A 6 havi BUBOR-jegyzések nyesés utáni szórásának historikus idősora 2006. január - 2012. június

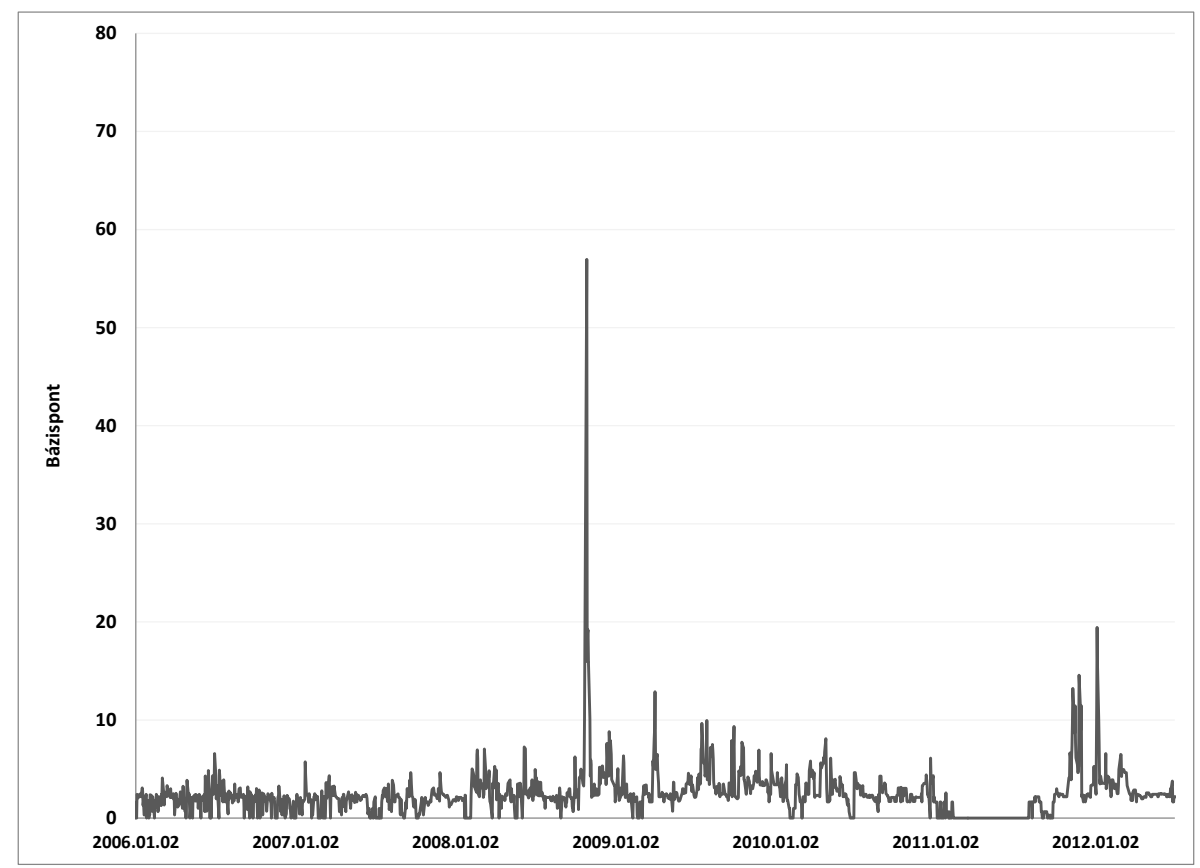

forrás: $M N B$, saját szerkesztés

Ez alapján látható, hogy az aktív kamatjegyző intézmények nagyon közel jegyeznek egymáshoz, a jegyzéseikben lényegi különbséget nem jelenítenek meg, vagyis a piacról alkotott képük nagyon hasonló. Az egyetlen kilógó érték 2008. október 27-hez, a válság 
Magyarországra való begyürüzésének kezdetéhez kapcsolható. Ekkor az intézmények nagy bizonytalansággal tekintettek a piacra, és a jövőbeli kamatszinteket ki pesszimistábban, ki optimistábban ítélte meg az első napon. Ezt a véleménykülönbséget jeleníti meg az október 27-i kiugró érték.

\subsubsection{Egyedi intézményi BUBOR-jegyzések}

A további elemzések előtt érdemes megvizsgálni az egyedi intézményi jegyzéseket. Az előző fejezetben látható, hogy 2012 júniusáig az aktív kamatjegyző intézmények által rögzített értékek szórása a kereskedési napok többségén nagyon alacsony szinten mozgott, vagyis az intézményi vélekedések nem különböztek jelentősen. Azonban ez még nem jelenti azt, hogy egy adott intézmény esetén nem merülhet fel a manipuláció gyanúja. Ugyanis elégséges csak tartósan a nyesett átlag (BUBOR) felett vagy alatt jegyeznie az adott intézménynek ahhoz, hogy a referencia-kamatra egy fel- vagy egy lefelé irányuló folyamatos nyomást alakítson ki. Ennek elemzéséhez megvizsgáltam az intézmények jegyzésének és a napi BUBORértékeknek a kapcsolatát. A 8.6. Melléklet tartalmazza 16 db 2012. június 30-ig valamely periódusban aktív kamatjegyzést végző intézmény napi 3 illetve 6 havi BUBOR-jegyzésének a vonatkozó BUBOR-értékektől vett eltéréseinek idősorát.

Fontos kiemelni, a BUBOR a LIBOR-ral szemben nem alkalmas szignálozásra, mivel definíció szerint az intézmények arról mondanak véleményt, milyen áron tudnak fedezetlen forint kölcsönt nyújtani, és nem pedig a forráshoz jutásuk költségét jelenítik meg. A derivatív pozíciók hatása A BUBOR-bázisú állományi adatok c. fejezetben leírt vizsgálat alapján szintén nem jelenik meg a BUBOR-értékében. Az intézmények mérlegbeli pozícióit tekintve - figyelembe véve azt a tényt, hogy az intézményeknél a folyósított hiteleknél nincs kiemelt törlesztési nap - a BUBOR-hoz köthető hitelállomány megközelítőleg 2000 milliárd forinttal meghaladja a BUBOR-hoz köthető betétállomány szintjét, melynek következtében a BUBOR lefelé való eltérítése alacsonyabb eredményhatással járna az intézmények számára.

A felsorolt tények miatt nincsen olyan ösztönző, mely a BUBOR csökkentését indukálná, ezért a 8.6 Melléklet ábráin azt vizsgálom, hogy 2006-2012 között volt-e olyan kamatjegyző intézmény, mely folyamatosan a BUBOR szintje felett jegyzett.

A vonatkozó melléklet ábrái alapján könnyen belátható, hogy egyetlen intézmény esetén sem azonosítható ilyen viselkedés. Sőt, az intézményi jegyzések döntő többsége a (BUBOR +/- 25 bázispontos) sávon belül maradt, mely a fentebb említett alacsony szórást eredményezi. 
Vagyis folyamatos egyirányú manipuláció, mint amilyen negatív irányban a LIBOR esetén megvalósult, nem azonosítható a BUBOR-jegyzések esetén.

A további elemzések elött az intézményi jegyzések esetén egy fontos tényezőt még ki kell emelni, mely jelentősen behatárolja az alkalmazható módszertanokat, amennyiben az intézmény által jegyzett adott napi BUBOR-értéket szeretnénk megbecsülni. Ehhez tekintsük „V” és „W” intézmény 3 illetve 6 havi BUBOR-jegyzések differenciáinak az idősorát:

11. ábra: „V” intézmény 3 havi BUBOR jegyzéseinek differencia idősora 2006. január - 2012. június

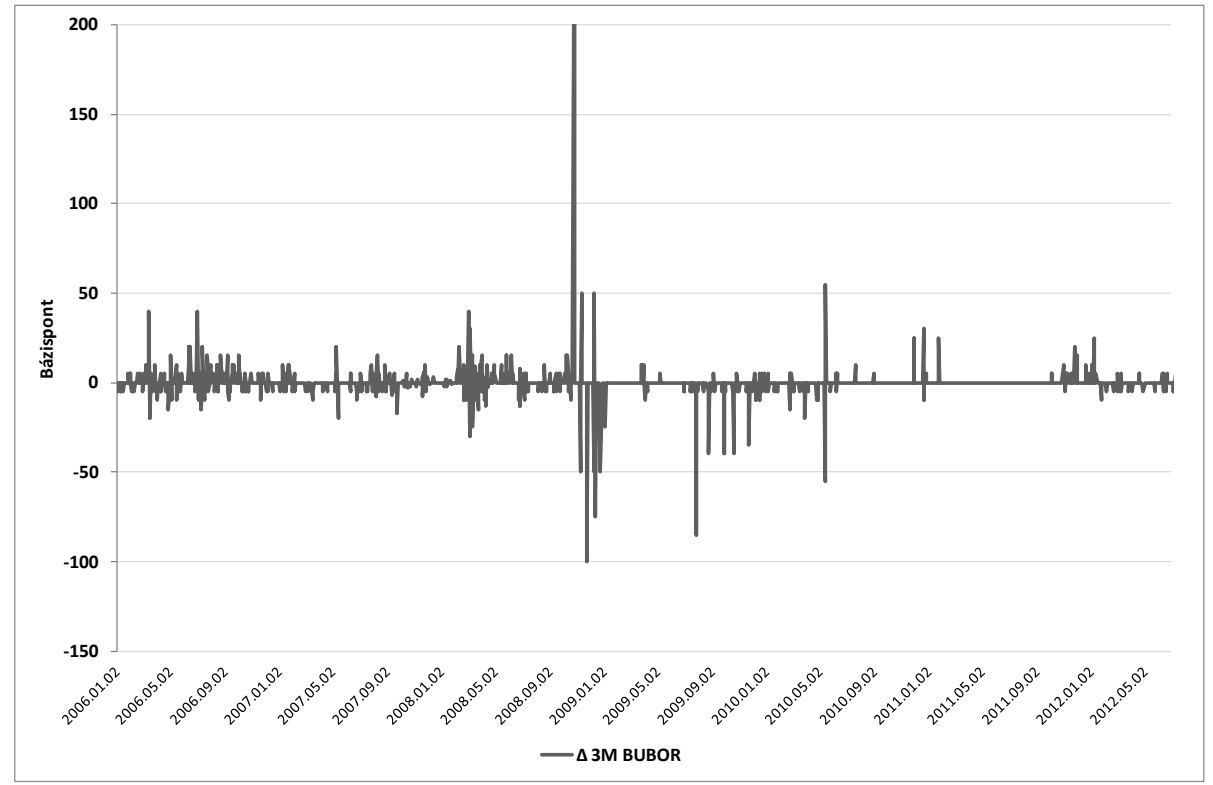

forrás: $M N B$, saját szerkesztés 
12. ábra: „V” intézmény 6 havi BUBOR jegyzéseinek differencia idősora 2006. január - 2012. június

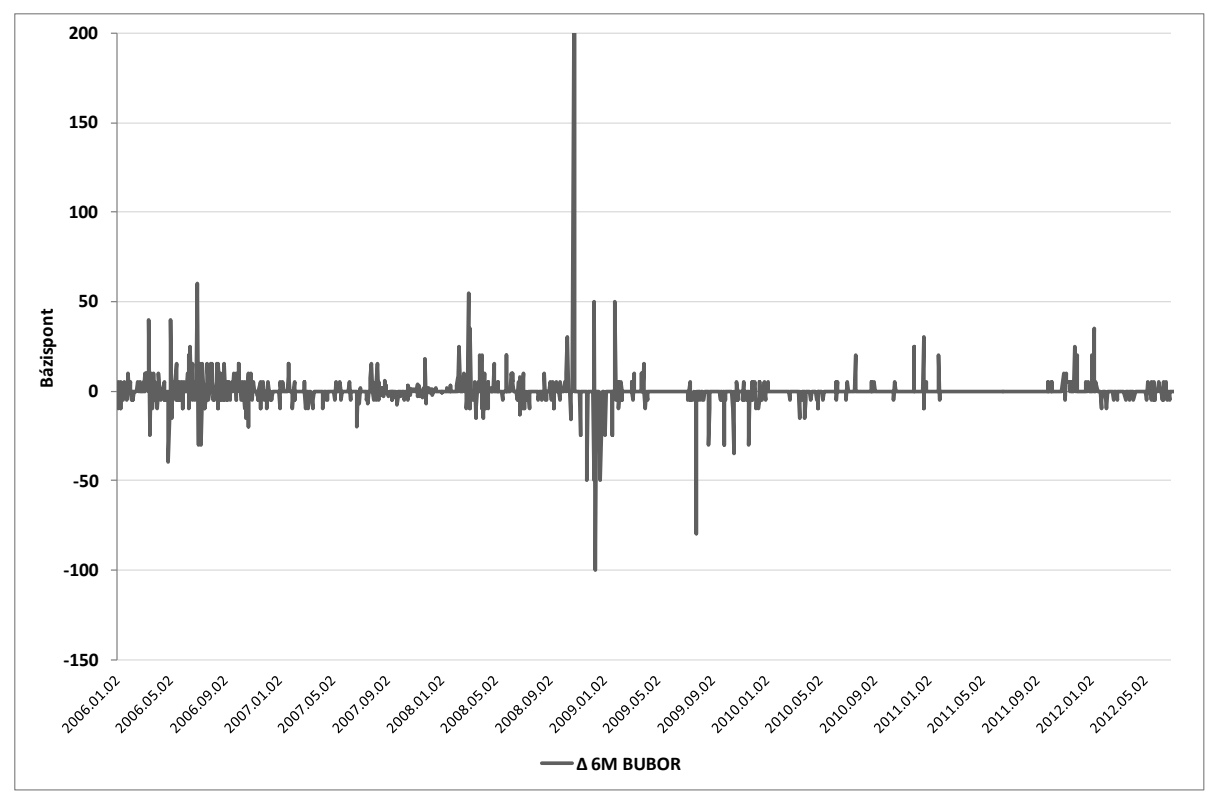

forrás: $M N B$, saját szerkesztés

„V' és „W” intézménynél mind a 3 havi, mind a 6 havi BUBOR-értékek differenciái esetén megfigyelhető, hogy 2008-ig sokkal gyakoribbak voltak a két egymást követő kereskedési nap közötti változtatások, melyek jellemzően +/-25 bázisponton belül maradtak. A 2008-as válság kitörése után a 10 bázispont feletti elmozdulások száma minimalizálódott. Tisztán kirajzolódik az ábrákból, hogy a BUBOR egy olyan terméket takar, melynek piaca fokozatosan kiürült (a differenciák sokkal szélsőségesebbek lettek az idő előrehaladtával), és az intézmények a jegyzés során igyekeznek valamilyen alternatív benchmarkot felhasználni ${ }^{68}$.

${ }^{68}$ Ezt a tényt interjú keretében a jegyzést végző kereskedők is kiemelték. A felhasznált benchmarkok bemutatását lásd bővebben az Alkalmazott benchmarkok c. fejezetet. 
13. ábra: „W” intézmény 3 havi BUBOR jegyzéseinek differencia idősora 2006. január - 2012. június

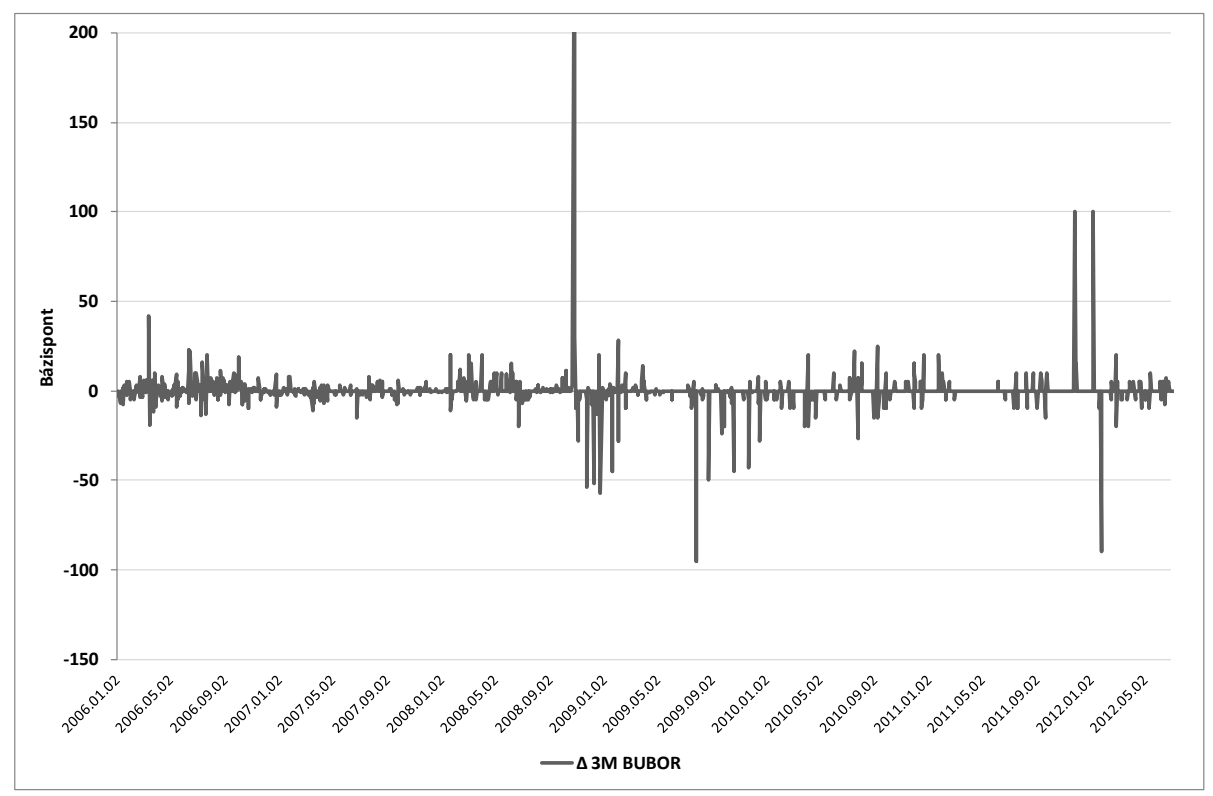

forrás: $M N B$, saját szerkesztés

14. ábra: „W” intézmény 6 havi BUBOR jegyzéseinek differencia idősora 2006. január - 2012. június

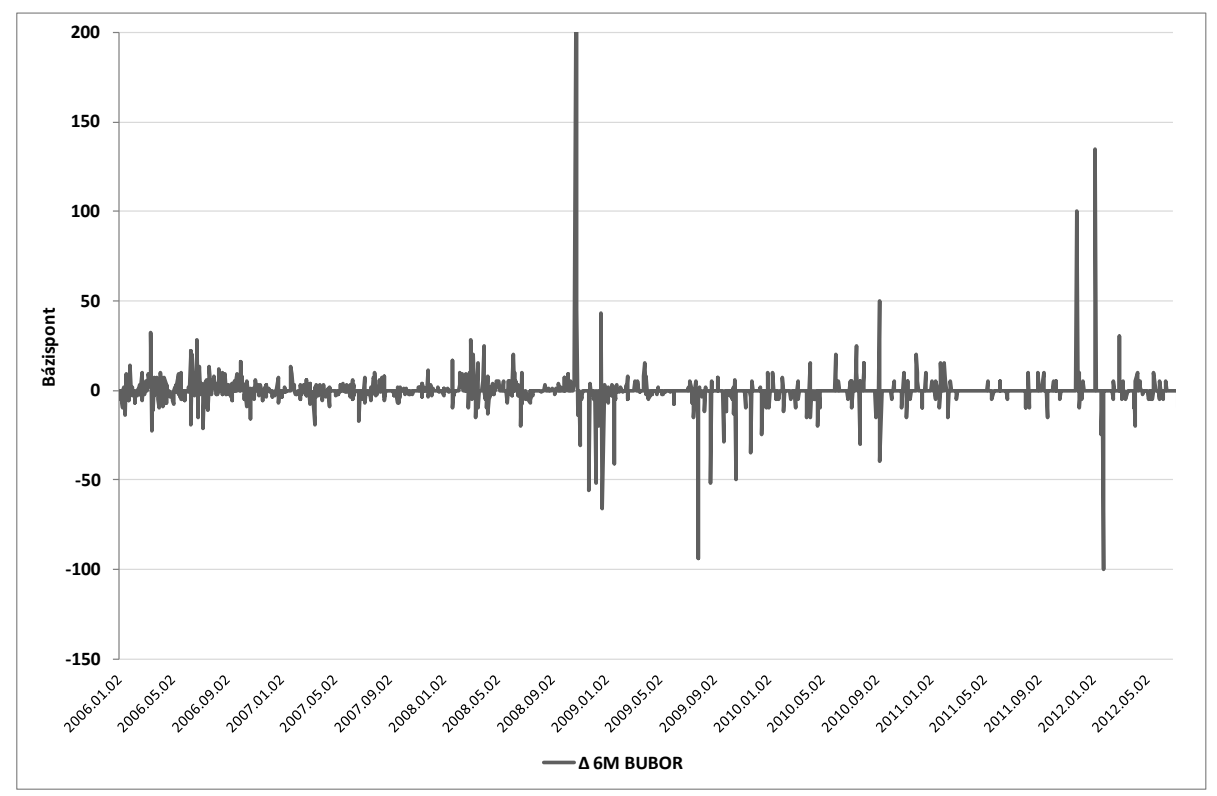

forrás: $M N B$, saját szerkesztés

Az egyedi jegyzések modellezését ez igen nehézkessé teszi, hiszen az elmozdulások sok esetben napokig nincsenek, vagy fix értékeket takarnak. Bár a BUBOR matematikai definíciója alapján arányskálán mérhető változóként meghatározható, az egyedi jegyzések során az intézmények - a kialakult gyakorlatot követve - az esetek többségében 5 bázisponttal osztható értéket jegyeznek. Ezt jól szemlélteti a 9. táblázat is. A táblázatból kiolvasható, hogy a „V” intézmény a 3 illetve a 6 havi BUBOR jegyzése során az általa rögzített előző napi 
értékhez képest a következő kereskedési napon a 2006. január - 2012. június közötti időszakban a kereskedési napok $95 \%$ illetve $94 \%$-án ${ }^{69} 0 ; 5 ; 10$ vagy 15 bázisponttal magasabb vagy alacsonyabb értéket jegyzett. A „W” intézmény esetén ez utóbbi értékek 76 illetve $73 \%{ }^{70}$. a 8.6. Melléklet ábrái alapján az aktív kamatjegyzők viselkedése „V” intézményhez állt közelebb.

Ezen túlmenően látható, hogy a vizsgált 1641-ből meghaladja az 1000-et azon kereskedési napok száma, mikor az intézmény nem tért el az előző napon jelentett értéktől. A piaci referencia-értékekre (az alapkamat kivételével) az ilyen típusú viselkedés nem jellemző, mivel folyamatosan épülnek be a piaci információk a megjelenített értékekbe.

9. táblázat: „V” és „W” intézmények 3 illetve 6 havi BUBOR-jegyzések differenciáinak gyakorisági táblája 2006. január - 2012. június

\begin{tabular}{|c|r|r|r|r|}
\hline Bázispont & \multicolumn{1}{|c|}{ "V" } & \multicolumn{1}{|c|}{ "V" } & "W" & "W" \\
& 3M BUBOR & 6M BUBOR & 3M BUBOR & 6M BUBOR \\
\hline $\mathbf{1 6 - 3 1 0}$ & 18 & 24 & 21 & 21 \\
$\mathbf{1 5}$ & $\mathbf{1 4}$ & $\mathbf{1 7}$ & $\mathbf{5}$ & $\mathbf{6}$ \\
$\mathbf{1 1 - 1 4}$ & 0 & 0 & 5 & 8 \\
$\mathbf{1 0}$ & $\mathbf{3 0}$ & $\mathbf{2 9}$ & $\mathbf{2 0}$ & $\mathbf{2 5}$ \\
$\mathbf{6 - 9}$ & 4 & 4 & 31 & 41 \\
$\mathbf{5}$ & $\mathbf{1 0 7}$ & $\mathbf{1 1 4}$ & $\mathbf{5 8}$ & $\mathbf{5 9}$ \\
$\mathbf{1 - 4}$ & 13 & 22 & 129 & 142 \\
\hline $\mathbf{0}$ & $\mathbf{1 2 5 5}$ & $\mathbf{1 1 9 0}$ & $\mathbf{1 0 8 6}$ & $\mathbf{1 0 1 3}$ \\
\hline $\mathbf{- 1 - 4}$ & 17 & 20 & 148 & 172 \\
$\mathbf{- 5}$ & $\mathbf{1 2 8}$ & $\mathbf{1 4 4}$ & $\mathbf{6 3}$ & $\mathbf{5 7}$ \\
$\mathbf{- 6 - 9}$ & 3 & 5 & 26 & 32 \\
$\mathbf{- 1 0}$ & $\mathbf{2 7}$ & $\mathbf{4 4}$ & $\mathbf{1 8}$ & $\mathbf{2 1}$ \\
$\mathbf{- 1 1 - 1 4}$ & 2 & 1 & 6 & 9 \\
$\mathbf{- 1 5}$ & $\mathbf{5}$ & $\mathbf{7}$ & $\mathbf{5}$ & $\mathbf{9}$ \\
$\mathbf{- 1 6 - 1 0 0}$ & 18 & 20 & 20 & 26 \\
\hline
\end{tabular}

forrás: MNB, saját szerkesztés

Ezen tulajdonságokat az idősor kettévágásával is megvizsgáltam. Vágási pontnak a - az értekezés többi fejezetével összhangban - a globális válság Magyarországra való begyürüzését, 2008. október 22-ét választottam. A 10. és a 11. táblázatból látható, hogy az előzőekben említett jegyzési tulajdonságok a válság után felerősödtek. A „V” intézmény a válság előtt a 3 havi BUBOR esetén a kereskedési napok 63\%-án ${ }^{71}$, a 6 havi BUBORjegyzése során a kereskedési napok 57\%-án nem módosított az előző napi jegyzésén. Ezen arányok 2008. október 28-a utáni vizsgált időszakban tovább növekedtek $87 \%$ illetve 85\%-ra.

\footnotetext{
${ }^{69} 0,94=(14+30+107+1255+128+27+5) / 1641$ és $0,95=(17+29+114+1190+144+44+7) / 1641$

${ }^{70} 0,76=(5+20+58+1086+63+18+5) / 1641$ és $0,73=(6+25+59+1013+57+21+9) / 1641$

${ }^{71} 0,63=443 / 707$
} 
Ez a tendencia a „W” intézmény esetében is megállapítható. A 3 havi BUBOR esetében az arány 48\%-ról 80\%-ra növekedett, míg 6 havi BUBOR esetén 41\%-ról 78\%-ra. Amennyiben a $0 ; 5 ; 10$ vagy 15 bázisponttal való elmozdulásokat vizsgálom, „V” intézmény esetében mind a 3, mind a 6 havi tenor esetén az arány a válság után 98\%-ra növekedett, vagyis mindössze a kereskedési napok 2\%-án módosított ettől eltérő mértékben az előző napi jegyzésén. „W” intézmény esetében a válság előtti megközelítőleg 50\%-os szintről a 0;5;10 vagy 15 bázispontos elmozdulások aránya 90\%-ra emelkedett.

A piaci referenciaértékekre (az alapkamat kivételével) ilyen típusú viselkedés nem jellemző, mivel folyamatosan épülnek be a piaci információk a megjelenített értékekbe. A 10-13. ábrákból kirajzolódik, hogy a BUBOR egy olyan terméket takar, melynek piaca fokozatosan kiürült (a differenciák sokkal szélsőségesebbek lettek az idő előrehaladtával), és az intézmény a jegyzés során valamilyen alternatív definíció alkalmazására törekszik, mivel a jegyzéseiben nem tükröződnek egy dinamikusan müködő piac folyamatos változásai.

10. táblázat: „V" és „W" intézmények 3 illetve 6 havi BUBOR-jegyzések differenciáinak gyakorisági táblája 2006. január 2. - 2008. október 22.

\begin{tabular}{|c|r|r|r|r|}
\hline \multirow{2}{*}{ Bázispont } & "V" & "V" & "W" & "W" \\
& 3M BUBOR & 6M BUBOR & 3M BUBOR & 6M BUBOR \\
\hline $\mathbf{1 6 - 3 1 0}$ & 10 & 14 & 10 & 12 \\
$\mathbf{1 5}$ & $\mathbf{1 3}$ & $\mathbf{1 6}$ & $\mathbf{2}$ & $\mathbf{1}$ \\
$\mathbf{1 1 - 1 4}$ & 0 & 0 & 4 & 8 \\
$\mathbf{1 0}$ & $\mathbf{2 2}$ & $\mathbf{2 4}$ & $\mathbf{9}$ & $\mathbf{1 1}$ \\
$\mathbf{6 - 9}$ & 4 & 4 & 27 & 35 \\
$\mathbf{5}$ & $\mathbf{7 5}$ & $\mathbf{7 5}$ & $\mathbf{2 9}$ & $\mathbf{2 4}$ \\
$\mathbf{1 - 4}$ & 13 & 22 & 108 & 123 \\
\hline $\mathbf{0}$ & $\mathbf{4 3}$ & $\mathbf{4 0 0}$ & $\mathbf{3 4 1}$ & $\mathbf{2 8 9}$ \\
\hline $\mathbf{- 1 - 4}$ & 17 & 20 & 122 & 137 \\
$\mathbf{- 5}$ & $\mathbf{7 6}$ & $\mathbf{8 2}$ & $\mathbf{2 5}$ & $\mathbf{2 1}$ \\
$\mathbf{- 6 - 9}$ & 3 & 5 & 21 & 26 \\
$\mathbf{- 1 0}$ & $\mathbf{2 0}$ & $\mathbf{3 1}$ & $\mathbf{1}$ & $\mathbf{7}$ \\
$\mathbf{- 1 1 - 1 4}$ & 2 & 1 & 5 & 4 \\
$\mathbf{- 1 5}$ & $\mathbf{4}$ & $\mathbf{5}$ & $\mathbf{1}$ & $\mathbf{2}$ \\
$\mathbf{- 1 6 - 1 0 0}$ & 5 & 8 & 2 & 7 \\
\hline
\end{tabular}

forrás: $M N B$, saját szerkesztés 


\section{1. táblázat: „V” és „W” intézmények 3 illetve 6 havi BUBOR jegyzések differenciáinak gyakorisági} táblája 2008. október 27. - 2012. június 30.

\begin{tabular}{|c|r|r|r|r|}
\hline Bázispont & "V" & "V" & "W" & "W" \\
& 3M BUBOR & 6M BUBOR & 3M BUBOR & 6M BUBOR \\
\hline $\mathbf{1 6 - 1 0 0}$ & 8 & 10 & 11 & 9 \\
$\mathbf{1 5}$ & $\mathbf{1}$ & $\mathbf{1}$ & 3 & $\mathbf{5}$ \\
$\mathbf{1 1 - 1 4}$ & 0 & 0 & 1 & 0 \\
$\mathbf{1 0}$ & $\mathbf{8}$ & $\mathbf{5}$ & $\mathbf{1 1}$ & $\mathbf{1 4}$ \\
$\mathbf{6 - 9}$ & 0 & 0 & 4 & 6 \\
$\mathbf{5}$ & $\mathbf{3 2}$ & $\mathbf{3 9}$ & $\mathbf{2 9}$ & $\mathbf{3 5}$ \\
$\mathbf{1 - 4}$ & 0 & 0 & 21 & 19 \\
\hline $\mathbf{0}$ & $\mathbf{8 1 2}$ & $\mathbf{7 9 0}$ & $\mathbf{7 4 5}$ & $\mathbf{7 2 4}$ \\
\hline $\mathbf{- 1 - 4}$ & 0 & 0 & 26 & 35 \\
$\mathbf{- 5}$ & $\mathbf{5 2}$ & $\mathbf{6 2}$ & $\mathbf{3 8}$ & $\mathbf{3 6}$ \\
$\mathbf{- 6 - 9}$ & 0 & 0 & 5 & 6 \\
$\mathbf{- 1 0}$ & $\mathbf{7}$ & $\mathbf{1 3}$ & $\mathbf{1 7}$ & $\mathbf{1 4}$ \\
$\mathbf{- 1 1 - 1 4}$ & 0 & 0 & 1 & 5 \\
$\mathbf{- 1 5}$ & $\mathbf{1}$ & $\mathbf{2}$ & $\mathbf{4}$ & $\mathbf{7}$ \\
$\mathbf{- 1 6 - 1 0 0}$ & 13 & 12 & 18 & 19 \\
\hline
\end{tabular}

forrás: MNB, saját szerkesztés

A fejezetben bemutatott jegyzési tulajdonságok jelentősen szükítik a modellezési lehetőségeinket, és több intervallumskálán (vagy arányskálán) mért, folytonos változót eredményező módszertan alkalmazását lehetetlenítik el. Mivel a BUBOR konvergál a jegybanki alapkamathoz, az MNB Monetáris Tanácsának döntései egy szinteltolódást (ugrást) generálnak a BUBOR-szintjében. A múltbeli példák is mutatják, hogy egy adott évben akár 68 alkalommal is módosulhat a jegybanki alapkamat mértéke. A közelmúlt tapasztalatai alapján pedig ezen elmozdulás mértéke sem egyértelmüen meghatározható $(10,15$ bázispontra is volt példa, míg a múltban kizárólag 25-tel osztható kamatváltozásról döntöttek). Ebből következően egy egyszerü regressziós módszertan biztosan nem képes az

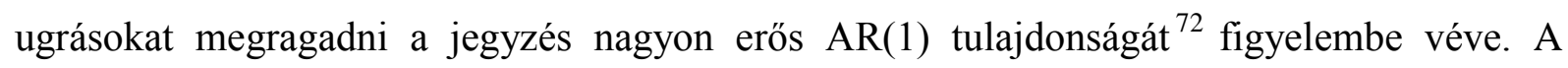
modellezést jelentősen nehezíti a kamatváltozások mértékének előrejelzése, melynek mértéke sok esetben eltér a többi piaci indikátor elmozdulásának mértékétől. Az indikátorok elmozdulásának és az alapkamat változtatásának mértékének kapcsolatának erőssége is időben változó (például a döntéshozók nem minden piaci turbulenciára reagáltak alapkamatváltoztatással). Emellett további kérdés, ezek a modellek vissza tudják-e adni azt a jegyzési tulajdonságot, hogy az intézmények a kereskedési napok több mint 90\%-án 0, 5, 10 vagy 15 bázispontot módosítanak az előző napi jegyzésükhöz képest. Ezen tények mentén érdemes

\footnotetext{
${ }^{72}$ lásd többek között Erhart-Ligeti-Molnár [2013]
} 
elgondolkodni, milyen információt is szeretnénk becsülni, és ennek függvényében módszertant választanunk.

$\mathrm{Az}$ 5.5. fejezetben változó transzformáció révén klaszterelemzést alkalmazok az egyedi viselkedés elemzésére, mellyel az itt felsorol problémákat is próbálom kiküszöbölni. Az elemzés során - az egyes intézmények valós jegyzési viselkedésének összevetése mellett arról próbálok információt szerezni, hogy az intézmény az adott kereskedési napon átlag alatti, átlagos vagy átlag feletti értéket jegyzett-e. Mindezek mellett fontos hangsúlyozni, hogy ezen modellek eredményeit a kiemelt körültekintéssel szabad értelmezni, hiszen manipulációval kapcsolatos megállapítást csak 100\%-os valószínüséggel szabad megfogalmazni. A külföldi felügyeleti hatóságok is kizárólag a jegyzési módszertan hiányosságainak azonosítására alkalmazták a statisztikai módszertanokat. A manipulálást írásos bizonyítékokkal (terminálon rögzített chatbeszélgetések, e-mailek) támasztották alá. Teljesen természetes ténynek tekinthető, hogy ilyen nagy horderejü esetekben csakis megdönthetetlen bizonyítékokra hagyatkoztak, melyekkel kapcsolatosan semmilyen kétség sem merülhetett fel. Az elemzésemben én sem törekszem ilyen horderejü megállapításokra. Célom a BUBOR-jegyzés tulajdonságainak, és az egyes aktív kamatjegyző intézmények viselkedésének elemzése.

\subsection{Benchmarkok vizsgálatának eredménye}

\subsubsection{Tenorok}

A BUBOR-t 2012 júniusában 15 tenorban számították. A gyakorlati tapasztalatok azt mutatják, hogy az intézmények mind a belső, mind az ügyfelek felé történő árazásában elsődlegesen az 1, 3 és 6 havi (1M, 3M és $6 \mathrm{M})$ értékeket alkalmazzák, ezért a további statisztikai elemzésekben elsődlegesen a hivatkozott három tenort veszem alapul. 
15. ábra: A jegybanki alapkamat és a BUBOR (1M, 3M, 6M) értékek alakulása 2004. január - 2012. június

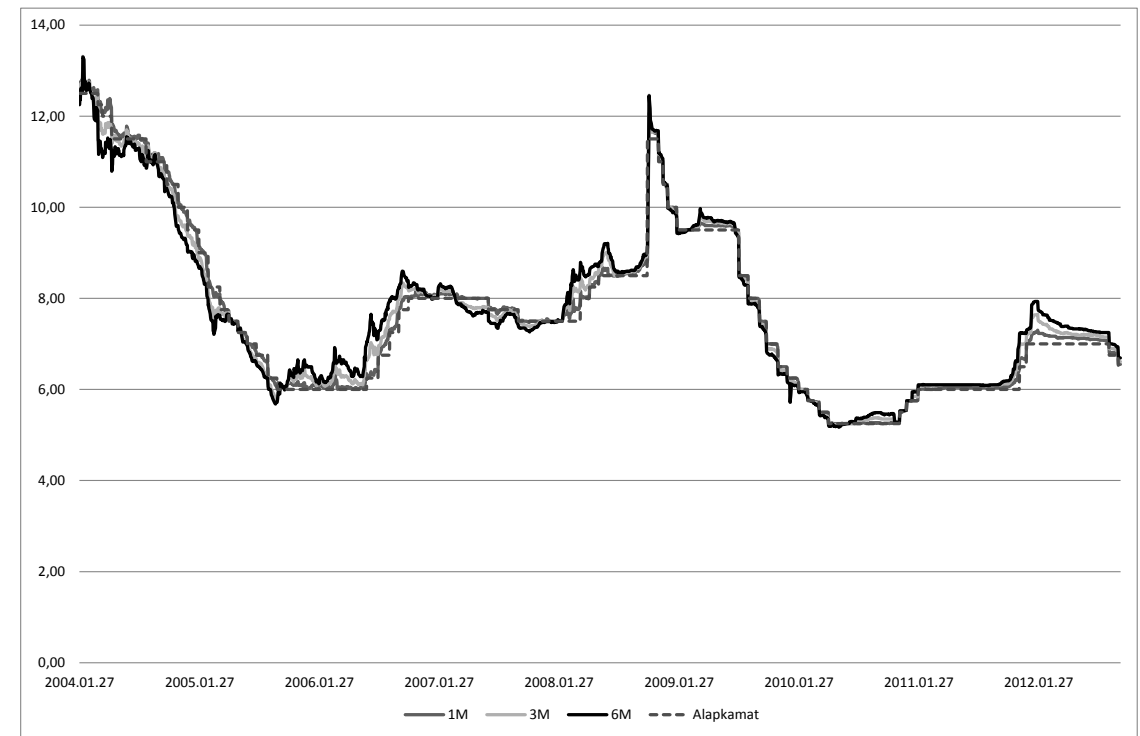

forrás: $M N B$, saját szerkesztés

A fenti ábrán is látható, hogy a BUBOR-jegyzések elsődlegesen a jegybanki alapkamathoz igazodnak, eltérések csak minimálisan tapasztalhatók, azonban a szektor viselkedésével kapcsolatosan érdemes ezeket is megvizsgálnunk. Tekintsük az alapkamat és a BUBORértékek közötti korrelációs mátrixokat. (A korrelációs mátrixokat az 8.3. Melléklet tartalmazza.)

Amennyiben a teljes időszakot (2004-2012) tekintjük, a BUBOR-értékek rendkívül szoros korrelációt mutatnak mind egymással, mind az alapkamat pályájával, a legkisebb korrelációs együttható is majdnem eléri a 0,98-at (6M - alapkamat). Vagyis látható, hogy a BUBORértékek csak nagyon minimális mértékben közvetítenek elözetes vélekedéseket az alapkamatról, és az alapkamat pályájának az aktuális mozgását követik.

12. táblázat: Jegybanki alapkamat változások évenkénti száma (db)

\begin{tabular}{lc}
\hline Év & $\begin{array}{c}\text { Alapkamat változások } \\
\text { száma }\end{array}$ \\
\hline 2007 & 2 \\
2008 & 7 \\
2009 & 7 \\
2010 & 6 \\
2011 & 3 \\
$2012.06 .30-\mathrm{ig}$ & 2 \\
\hline
\end{tabular}

forrás: $M N B$, saját szerkesztés 
Az elmúlt időszak piaci sokkhatásai miatt 2007-től kezdve a korrelációk alakulását éves diszkrét periódusokon is megvizsgáltam. Még a legkevésbé korreláló évek során is 0,7-0,8-as értéket vesznek fel. A 12. táblázatból látható, hogy 2007-ben illetve a 2011. január - 2012. júniusi periódusokban az alapkamat pályája stabil volt, évenként mindösszesen 2-3 változás történt a szintjében. A korrelációs értékek lecsökkenése ezen időszakokhoz kapcsolódik, hiszen ekkor - bár a jegybanki alapkamat szintje nem változott - a jegyzésnél figyelembe vett egyéb piaci benchmark-értékek változásokat indukáltak a BUBOR szintjében.

A 8.3. Melléklet korrelációs mátrixainak értékeiből továbbá látható, hogy az 1, 3 és 6 havi BUBOR közötti korreláció legkisebb értéke 0,88, vagyis szektorszinten az egyes tenorokhoz kötődő BUBOR-értékek megállapításánál nincsenek eltérő vélekedések, még a legvolatilisebb piaci környezetben sem. Ráadásul a tenoronkénti napi jegyzések nagyon közel helyezkednek el egymáshoz képest. A 16. ábra szemlélteti, hogy a 3 illetve 6 havi BUBOR-értékek különbsége ${ }^{73}$ 2007-2012 között jellemzően a +/-20 bázispontos sávban mozgott. Nagyobb eltérések csak 2008 és 2012 elején voltak, ekkor a 6 havi jegyzések 30-40 bázisponttal magasabb értéket mutattak, ami azt jelentette, hogy a piac a 4-6 hónap között további kamatemelkedéssel számolt és nem csupán a tartási költséget ${ }^{74}$ vette figyelembe, mint egy nagyon alacsony különbség esetén.

16. ábra: A 3 és 6 havi BUBOR-értékek eltérésének (bázispont) alakulása 2007. január - 2012. június

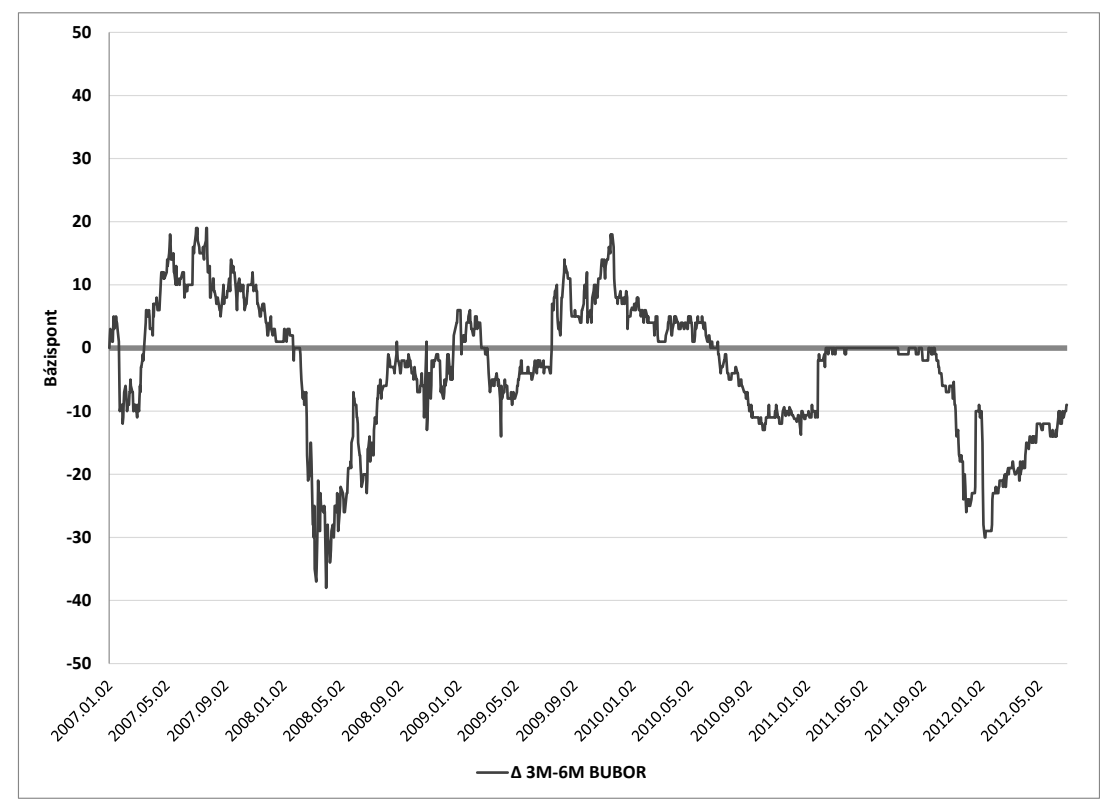

forrás: $M N B$, saját szerkesztés

\footnotetext{
${ }^{73} 3 \mathrm{M} \mathrm{BUBOR}_{\mathrm{t}}-6 \mathrm{M} \mathrm{BUBOR}$

${ }^{74}$ Hosszabb időre nyújtott hitel esetén a hitelező hosszabb ideig futja a hitelfelvevő nemfizetési kockázatát és ez a jövőbeli kamatvárakozások mellett beépül a hosszabb tenorok jegyzett értékeibe is.
} 
Az 1 és 6 havi BUBOR-értékek eltérésnek vizsgálatánál (17. ábra) látható, hogy az eltérések jelentősen növekedtek a 3-6 havi különbséghez képest és sok esetben meghaladják a +/-20 bázispontos szintet. Ez azt is jelenti, hogy nem csupán az időérték jelenik meg, hanem az esetek többségében egy érdemi kamatelmozdulást is áraztak az intézmények 6 hónapos időtávon.

17. ábra: Az 1 és 6 havi BUBOR-értékek eltérésének (bázispont) alakulása 2007. január - 2012. június

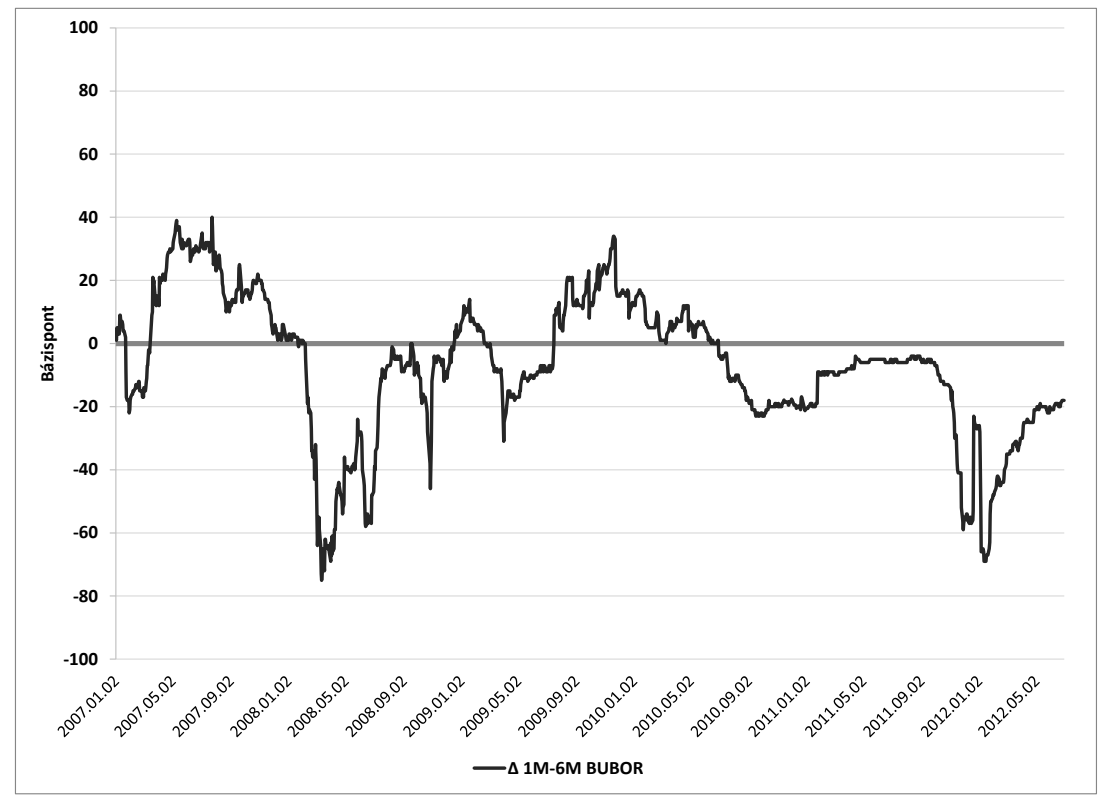

forrás: MNB, saját szerkesztés

Árazási szempontból különösen fontosak az előző bekezdés megállapításai, hiszen nem azonosítható olyan tenor, melyet az intézményeknek egyértelmüen célszerü lenne preferálniuk. Nincsen olyan tenor, melyet kiválasztva egyértelmüen pozitív eredményt realizálna. Hitelezési szempontból ez azt jelentené, hogy lenne olyan tenor, mely minden időpontban meghaladja a többi reálisan válaszható tenor jegyzését (pl.: a 3 havi BUBOR minden kereskedési nap magasabb mint az 1 havi). Ez közgazdaságilag az is jelentené, hogy a vizsgált időtartamok között nem jelenhetnének meg a jegyzésben csökkenő hozamvárakozások, így a kapcsolódó hozamgörbének ezen szakasza sosem lehetne ereszkedő. Egy ilyen típusú torzítás jelenléte szinte elképzelhetetlen, mivel ebben az esetben a jegyzés az alapvető közgazdasági elvárásoknak sem felelne meg, és gyorsan felkeltené mind a belső, mind a külső piaci szereplők figyelmét is. Ennek következtében a racionális piaci szereplők hosszú távon elfordulnának a terméktől. Súlyosabb esetben az elfordulást a szabályozó hatóságok is ösztönöznék, a referencia-érték reputációjának helyreállítása helyett. (Erre egy 
lehetséges mechanizmus, ha bizonyos termékek árazását a vizsgált referencia-értékkel szemben egy alternatív referencia-értékhez kötik.)

18. ábra: Az 1 és 3 havi BUBOR-értékek eltérésének (bázispont) alakulása 2007. január - 2012. június

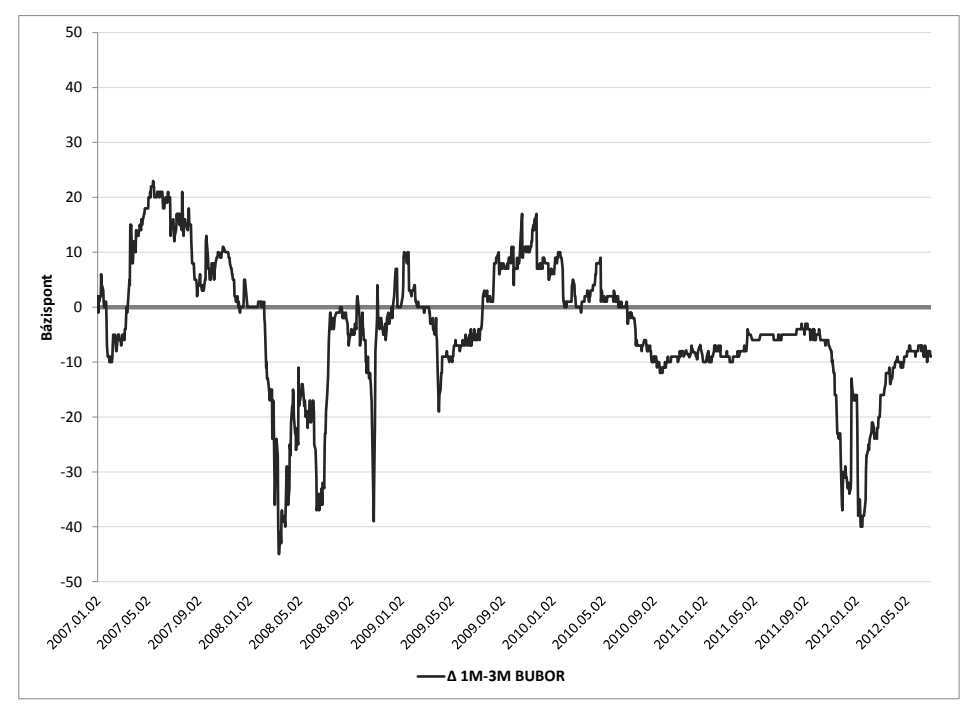

forrás: MNB, saját szerkesztés

A fejezet három ábrája (16., 17. és 18. ábra) is alátámasztja, hogy a BUBOR-piacon ilyen irányú torzítás nem alakult ki, hiszen a vizsgált BUBOR-tenorok eltéréseinek görbéi a piaci várakozásoknak megfelelően folyamatosan változnak, és emelkedő valamint ereszkedő hozamgörbét egyaránt tükröznek. Az ábrákon nem azonosítható tartósan állandó mértékü eltérés az egyes tenorok jegyzése között. Ez a tény is a múltbeli BUBOR-jegyzések definíció szerinti kialakítását támasztja alá.

Azonban nem hagyható figyelmen kívül, hogy a gyakorlatban kevésbé használatos tenorok ${ }^{75}$ jegyzését több intézmény is egy előre rögzített interpolációs képlet alapján határozta meg. Egyik leggyakrabban alkalmazott módszer a lineáris interpoláció volt, mely a köztes, szakértő által külön nem meghatározott tenorokat a linearitás elve alapján határozta meg. Ennek szemléltetésére tekintsük az alábbi példát:

13. táblázat: Példa a lineáris interpoláció alkalmazására a BUBOR-jegyzésben

\begin{tabular}{cccc}
\hline $\begin{array}{c}\mathbf{6} \text { havi BUBOR } \\
\text { (szakértői) }\end{array}$ & $\begin{array}{c}\mathbf{7} \text { havi BUBOR } \\
\text { (interpolált) }\end{array}$ & $\begin{array}{c}\mathbf{8} \text { havi BUBOR } \\
\text { (interpolált) }\end{array}$ & $\begin{array}{c}\mathbf{9} \text { havi BUBOR } \\
\text { (szakértöi) }\end{array}$ \\
\hline $\mathbf{5 , 2 \%}$ & $5,2 \%+(5,8 \%-5,2 \%) / 3=$ & $5,2 \%+2 *(5,8 \%-5,2 \%) / 3=$ & $\mathbf{5 , 8 \%}$ \\
& $\mathbf{5 , 4 \%}$ & $\mathbf{5 , 6 \%}$ & \\
\hline
\end{tabular}

${ }^{75}$ 2-4-5-7-8-10-11 havi tenorok. Ezen tenorok alkalmazása a vállalati szektorhoz köthető ügyletekre jellemző, alacsony darabszám mellett. Interpolációs módszertan megadása mellett az intézmények továbbra is képesek fenntartani a korábbi árazási gyakorlatukat. Pl. egy 7 hónapos vállalati hitel továbbra is 7 hónapos BUBOR alapján árazódik. 
Az alkalmazás hátterében az a tény állt, hogy nem volt olyan releváns bankközi piaci adat, mely az interpolációs mechanizmusnak megfelelő alternatívájaként szolgált volna. A fentiek következtében a tenorok számának szükítése nem csökkentené a BUBOR piaci szerepét. Egy elöre meghatározott interpolációs módszertan alkalmazása mellett a közvetlen jegyzések elhagyásából származó információhiány is megszüntethető.

Ezt a problémát a jegyzés koordinálásáért felelős Magyar Forex Társaság is felismerte. Az MFT elhagyta a jegyzésből a kevésbé használatos tenorokat és 2014 februárjától csak az alábbi kilenc tenorban történik a referencia-kamat rögzítése: overnight $(\mathrm{O} / \mathrm{N}), 1$ hét, 2 hét, 1 , 2, 3, 6, 9 és 12 hónap.

\subsubsection{Alkalmazott benchmarkok (alapkamat, DKJ, swap és FRA ${ }^{76}$ )}

A következő részben a BUBOR és a benchmark értékek kapcsolatát vizsgálom. Célom, hogy megvizsgáljuk a piaccal rendelkező forint-bázisú lehetséges helyettesítő termékek kapcsolatának idöbeli alakulását a 2006. január - 2012. június közötti periódusra vonatkozóan. A benchmarkok és a BUBOR-értékek közötti kapcsolatot korrelációs értékek alapján szemléltetem. A korrelációkat egy 250 kereskedési napos mozgóablak segítségével vizsgáltam, és idősorosan ábrázoltam az értékeket. Így a kapott ábrákon (19-20. ábra) az időbeli kapcsolatokra is következtethetünk.

A BUBOR meghatározása során a kamatjegyzést végző kereskedök több benchmarkot is figyelembe vesznek: a kéthetes MNB kötvény (kamatszintje az aktuális jegybanki alapkamat), az FRA (forward rate aggreement) jegyzések, a swap jegyzések, az FX swap ${ }^{77}$ implied kamatok, a diszkontkincstárjegy (DKJ) hozamok értékeit. Azonban itt is nagyon fontos megjegyezni, hogy piaci benchmark adatok szinte kizárólag a rövid oldali tenorokra vannak, az 1 hónapnál hosszabb jegyzések majdnem teoretikusnak tekinthetők. A 19. és 20. ábra a BUBOR-jegyzések és a benchmarkok alakulását szemléltetik 3 illetve 6 hónapos tenor esetén. (A Swap- és az FRA-értékek forrása: Bloomberg.)

\footnotetext{
${ }^{76}$ A BUBOR-értékek FRA hozamokkal való összevetését jelentősen torzítja az tény, hogy az FRA egy forward kamatszintet mutat. Ugyanakkor arra feltétlen szolgáltat információkat, hogy a jövőbeni várakozások, mely periódusokban és milyen mértékben épültek be BUBOR-jegyzésekbe. Az elemzésben való alkalmazását az a tény is erősíti, hogy a jegyzést végző kereskedők több esetben is említették, mint figyelembe vett piaci információt.

${ }^{77}$ Definíciót lásd 8.7. Melléklet.
} 
19. ábra: 3 hónapos BUBOR és egyes benchmarkok alakulása 2007. január - 2012. június

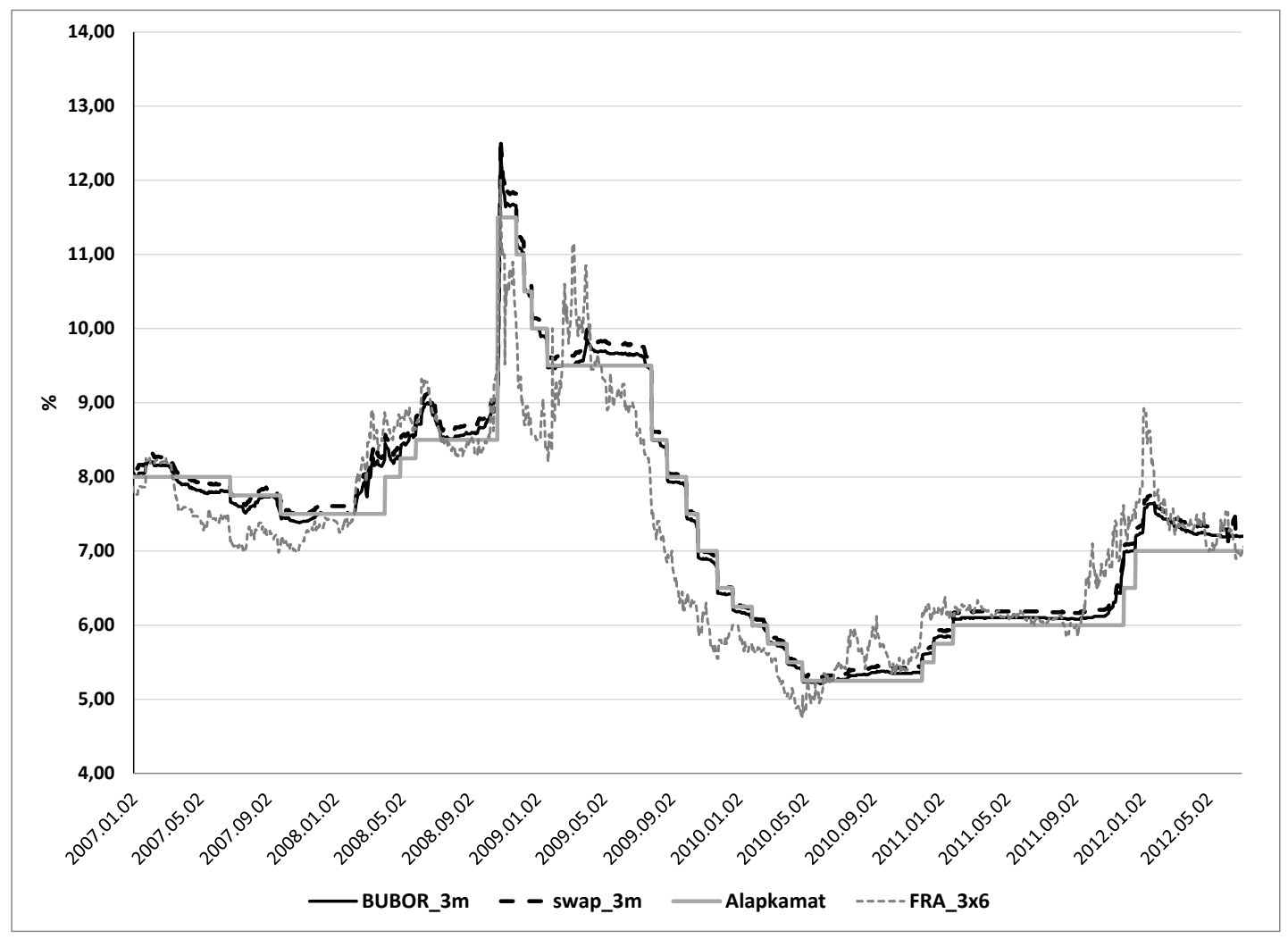

forrás: $M N B$, saját szerkesztés

20. ábra: 6 hónapos BUBOR és egyes benchmarkok alakulása 2007. január - 2012. június

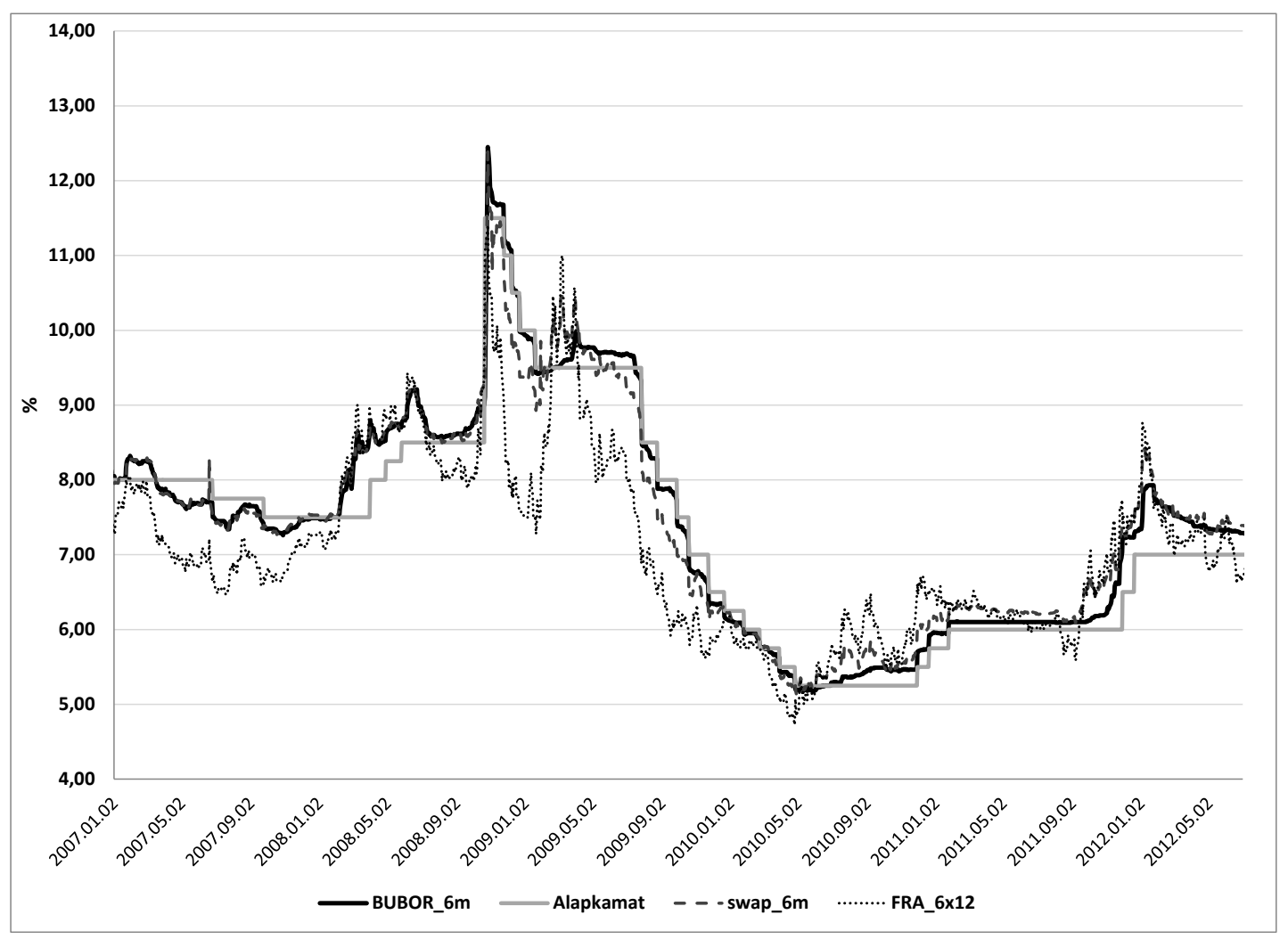

forrás: $M N B$, saját szerkesztés 
Az ábrákon jól látható, hogy a BUBOR-értékek 2008 őszétől elsődlegesen a jegybanki alapkamat szintjéhez igazodnak. Ugyanakkor 2011 negyedik negyedévétől megfigyelhető egy újabb elszakadás, mikor a swap értékek erőteljesen befolyásolni kezdték a referencia-kamat értékét, és elszakadtak a jegybanki alapkamat pályájától. Jelentősebb eltérések tapasztalhatók a piaci turbulens időszakokban, mikor egy sokkhatás esetén a kamatjegyzők a jövőbeli várakozásaikat fokozottabban megjelenítették a jegyzéseikben. A benchmarkok szerepe is megfigyelhető, bár hatásuk elsősorban azokban az időszakokban érvényesült, mikor a jegybanki alapkamat pályája hosszabb ideig stabil volt.

A swap és az FRA értékek közül elsősorban a swap értékek jelennek meg a BUBOR szintjében. Az FRA értékek esetében sokkal szélsőségesebb értékek tapasztalhatók (pl.: 2009. január és 2012. január), értékei sokkal kevésbé voltak hajlamosak az alapkamattól jelentősen eltérő szélsőséges jegyzésekre. A swap értékekhez való alkalmazkodásnak magyarázata az is, hogy az intézmények a banki könyvi kamatpozícióikat elsődlegesen swap ügyletekkel (nem FRA-val) zárják, így a kockázati profiljukra a swap-hoz kötődő referencia-értékek nagyobb befolyással vannak. Ez a tény szintén a BUBOR-definíció helyes alkalmazását támasztja alá, hiszen a jegyzésnél minden intézménynek arra kell válaszolnia, milyen áron tudna fedezetlen hitelt kihelyezni. Ezt jelentősen befolyásolja a piacon lévő többi intézmény fedezeti pozíciója, melyek forint részének jelentős hányadát teszik ki swap ügyletek.

Megjegyzendő, hogy ez utóbbi következtetést a Bloomberg által meghatározott értékei alapján vontam le, és ezek eltérhetnek az intézmények által alkalmazott értékektől.

A BUBOR-értékek és az egyéb benchmarkok korrelációjának vizsgálatnál hasonló következtetésekre juthatunk (21. és 22. ábra). A korreláció számításánál 250 kereskedési napos megfigyelési periódust vettem alapul, és a számított korrelációkat kereskedési naponként elöre görgetve diagramon ábrázoltam. Fontos kiemelni, hogy az ábrákon megjelenik az autokorreláció, mivel a méréseket nem diszjunkt (átfedés nélküli) időintervallumokon végeztem.

Mind a 3, mind a 6 hónapos BUBOR-értéknél jól látható - figyelembe véve az autokorrelációt is -, hogy azon időszakokban, mikor a jegybanki alapkamat szintje mozgásban van, a benchmarkok szorosan korrelálnak a BUBOR-értékekkel. Ez utóbbi tényt az MNB tanulmánya is megerősítette (Erhart - Ligeti - Molnár [2013]). A kevésbé volatilis időszakban a kapcsolat erőssége csökken, és valamely benchmark-érték felé tolódik el. Utóbbit jelzik a korrelációt ábrázoló görbék beszakadásai. (A görbe egy adott pontja az előző 250 kereskedési nap együttmozgását jeleníti meg. Vagyis a 2011. december 11-i érték a megelőző 250 
kereskedési nap tényértéke alapján adódik, és a múltbeli eseményeket jeleníti meg. Ebből következőleg a volatilis események késleltetve jelennek meg a korrelációs görbéken.)

A kapott ábrák alapján a főbb benchmarkok a 3 hónapos BUBOR-jegyzés esetén a swapilletve a DKJ-értékek, a 6 hónapos BUBOR-jegyzés esetén pedig elsődlegesen a swapértékek. Az FRA-jegyzésekkel a kapcsolat szintén nem elhanyagolható, de jóval gyengébb, mint a swap-jegyzésekkel.

21. ábra: 3 hónapos BUBOR és benchmarkok közötti korreláció 2007. január - 2012. június: bal skála korreláció; jobb skála - alapkamat szintje \%

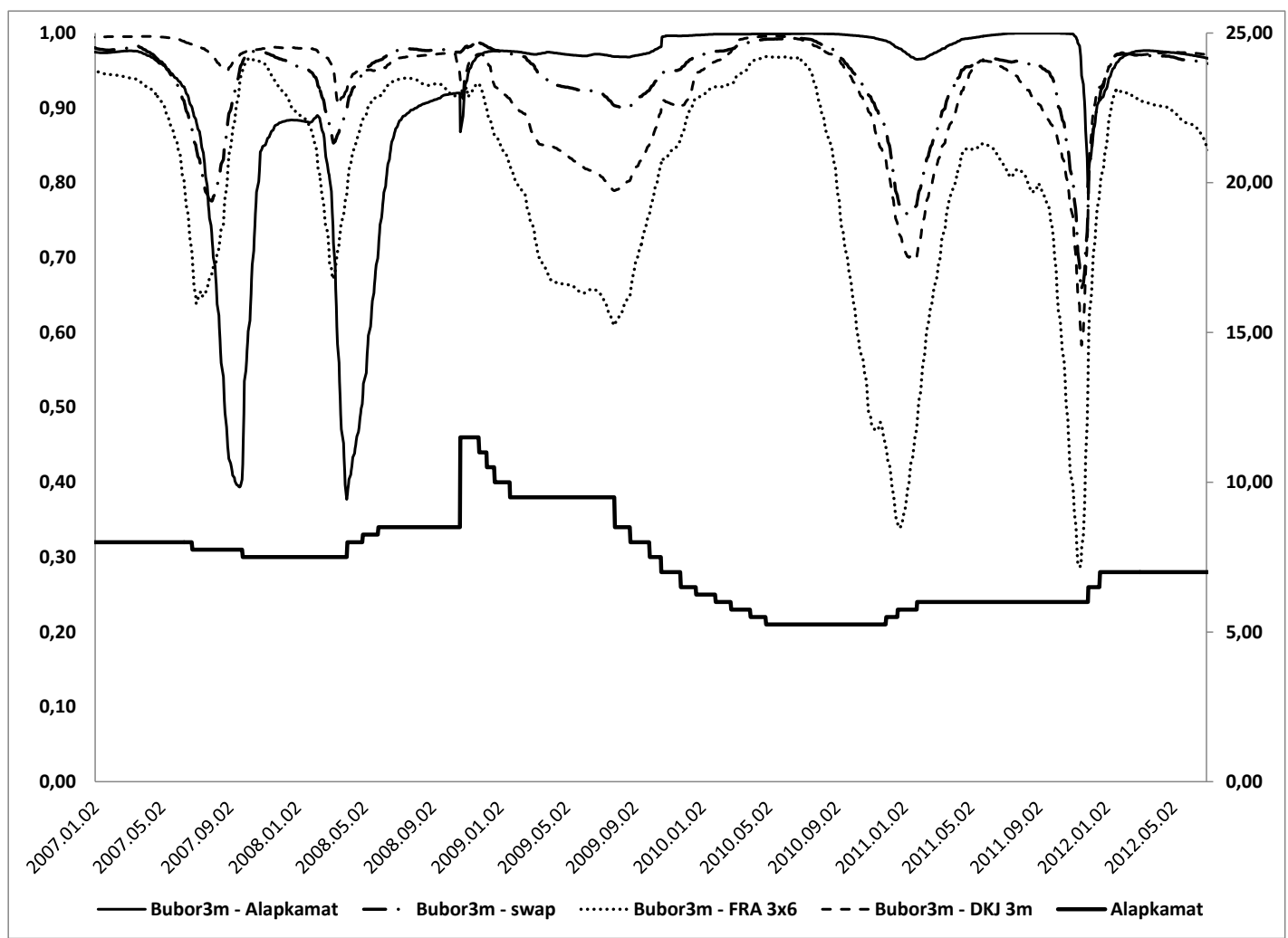

forrás: $M N B$, saját szerkesztés 
22. ábra: 6 hónapos BUBOR és benchmarkok közötti korreláció 2007. január - 2012. június: bal skála korreláció; jobb skála - alapkamat szintje \%

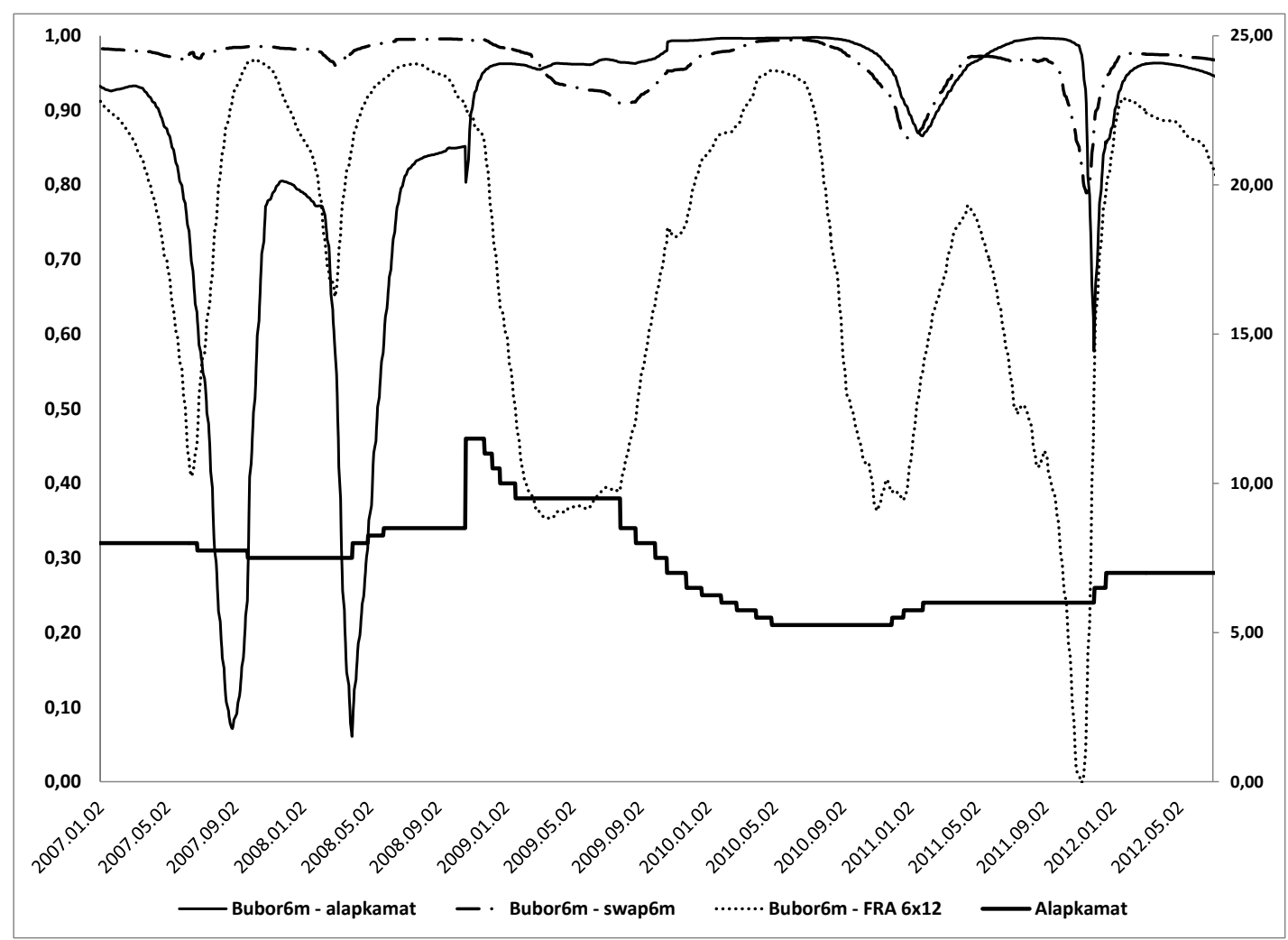

forrás: MNB, saját szerkesztés

A 21. és 22. ábra alapján a várakozások az FRA-értékekben jelennek meg a legerősebben. A piac likviditása miatt az FRA-értékek mozgása tekinthető a legvolatilisebbnek. A várakozások időbeli megjelenése is megfigyelhető a fenti két ábrán. Egyértelműen látható, hogy a kamatvárakozások elsőként az FRA-, ezt követően a swap-, és legkésőbb a BUBORértékekben jelennek meg. Ugyanis a BUBOR-FRA korrelációs görbe kezd elöször beszakadni, mely annyit jelent, hogy a BUBOR-tól eltérő információk először az FRAértékekbe épülnek be. Az alapkamat pályáját a BUBOR-ral összevetve megállapítható, hogy az esetek többségében a BUBOR jelentősebb elmozdulásai a jegybanki alapkamat szintjének a változásait jelenítik meg.

Emellett nem hagyható figyelmen kívül a benchmarkok szintje a sokk időpontokban (2008. október, 2009. március és 2011. december - 2012. január). Ekkor az alapkamat szintje is változott, de a benchmark-értékek a nagyfokú piaci bizonytalanság miatt magasabb elmozdulást áraztak, és ez a szint a BUBOR-jegyzésben is tükröződött. A bizonytalanság fokozatos csökkenésével a BUBOR-jegyzések ezekben a sokk-periódusokban fokozatosan visszakonvergáltak az alapkamat szintjéhez a kezdeti „túlhúzás” után. Ez alól enyhe kivétel a 
2012. január, mikor a BUBOR nyugalmi szintje inkább a swap-görbéhez igazodott, és tartósan megfigyelhető egy 30-40 bázispontos eltérés az alapkamathoz képest.

A fenti két ábráról a piac kiszáradása is leolvasható. 2008 októbere előtt a benchmarkok és a BUBOR alkalmazkodása sokkal gyorsabban történt meg (a korrelációk görbéinek beszakadásai sokkal szükebbek), mint a 2010-2012 közötti időszakban. A BUBOR és az alapkamat pálya közötti korreláció is sokkal szorosabb a válság kezdete óta. (Lásd 21. és 22. ábra). Ez annak a ténynek a következménye, hogy a válság után egy részben teoretikus termékről beszélhetünk, melynek alkalmazkodási képessége a piaci változásokhoz sokkal gyengébb.

Jelenleg a BUBOR-t meghatározó fedezetlen bankközi hiteleknek nincsen piaca, ezért elemzésükhöz elengedhetetlen a benchmarkok/proxyk vizsgálata. A jegyzések elsődlegesen az alapkamat pályáját követik. A múltbeli jegyzések elemzése alapján látható, hogy a BUBOR nem helyettesíthető az alapkamattal, hiszen a jegyzéseket rendszeresen befolyásolják a helyettesítő termékek referencia-értékei is. A piac kiszáradásával a BUBOR alkalmazkodási képessége jelentősen gyengült. A BUBOR mint piaccal rendelkező referencia-érték szerepének minél teljesebb betöltéséhez fontos a BUBOR-piac újraindulása.

A különböző futamidőre jegyzett BUBOR-kamatok különböző időértékeket is tükröznek, ezért sem helyettesíthetők a fix kéthetes időtávban értelmezhető alapkamattal.

\subsubsection{Az egyetlen ,aktív" tenor}

Erhart, Ligeti és Molnár 2013-as tanulmányában megállapította, hogy a BUBOR esetén közepesen aktív tenornak kizárólag az egynapos (overnight) tenor tekinthető (Erhart - Ligeti - Molnár [2013]). A többi tenor esetében a piaci szereplők aktivitása nagyon alacsony, és az előző fejezetekben ismertetett anomáliák tapasztalhatók a jegyzésben. A LIBOR esetében azonban nem lenne ilyen „egyszerü” a helyzet. Erharték rámutattak, hogy például az amerikai dollár LIBOR esetében az egynapos és egyhetes tenorokban a piaci aktivitás kifejezetten magas, míg a 2 hetestöl a 3 hónapos tenorig közepes, vagyis a tenorok mintegy $40 \%$-a aktívnak tekinthető. A következőkben az egynapos tenort részletesebben bemutatom, rávilágítva, hogy egy közepesen aktív piac esetén a jegyzésnek mennyivel más tulajdonságai vannak. 
23. ábra: Az egynapos BUBOR és a jegybanki alapkamat alakulása 2006. január - 2012. június

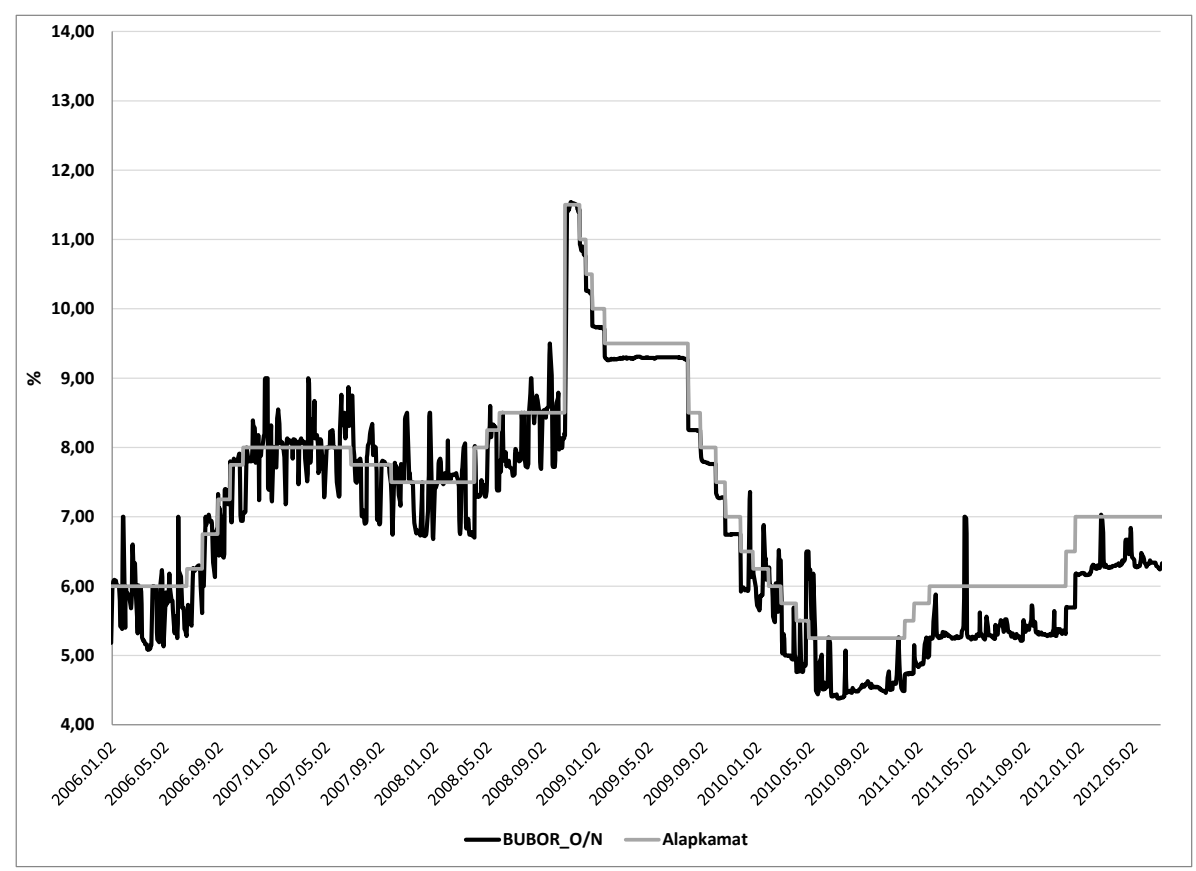

forrás: $M N B$, saját szerkesztés

A jegybanki alapkamat és az egynapos BUBOR idősorának ábrájából jól látható, hogy 2008 októberéig, a globális válság Magyarországra való begyürüzésének időpontjáig az egy napos BUBOR jegyzése a többi tenorhoz képest egy aktív piacot tükrözött, melynek trendjét a jegybanki alapkamat pályája határozta meg. Az egy napos tenor jegyzései az alapkamat szintje körül ingadoztak. Ennek az ingadozásnak a mértéke jelentősen lecsökkent a 2009 2012 közötti periódusra, melyből arra következtethetünk, hogy a BUBOR-piacának kiszáradási folyamata az egynapos tenort is egyre fokozottabban érintette. Azonban az ábra alapján egyértelmüen látható, hogy 2008 októberétől az egynapos BUBOR átlagos szintje az alapkamat szintje alatt ingadozott. 
24. ábra: Az egynapos BUBOR napi jegyzéseinek szórása bázispontban 2006. január - 2012. június

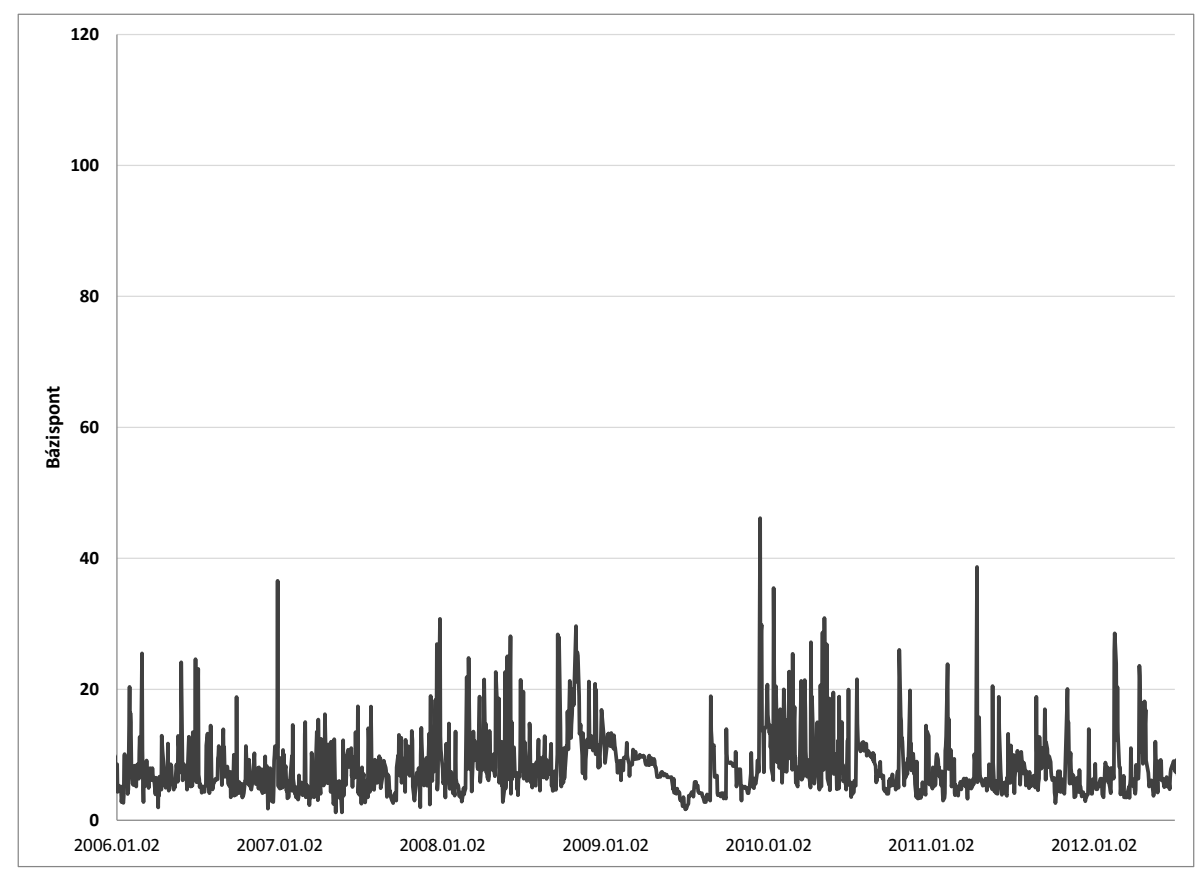

forrás: $M N B$, saját szerkesztés

Az egynapos tenor szórásai is arra utalnak (24. ábra), hogy a korábban vizsgált 1, 3 és 6 havi tenorokhoz képest az aktív kamatjegyző bankok véleménye sokkal heterogénebb az egynapos tenor esetén. Ennek hátterében az a tény áll, hogy egy aktív piac minél pontosabb leírásához sokkal több információra van szükség és ezen információk nem egyenlő mértékben állnak az aktív kamatjegyző intézmények rendelkezésére. Az eltérő mennyiségü információ egy egészséges mértékü diverzifikációt eredményez, melyet az egynapos jegyzések szórása is tükröz. Ennek eredményeképpen a leadott jegyzések szórása az egynapos tenor esetén 5-15 bázispont között mozgott 2006-2012 között, és számos kereskedési nap meghaladta a 20 bázispontos értéket is.

14. táblázat: A főbb BUBOR-tenorokhoz tartozó napi jegyzések szórásának középértékei és maximuma a 2006. január - 2012. június közötti időszakra, bázispontban

\begin{tabular}{lcccc}
\hline & BUBOR_O/N & BUBOR_1M & BUBOR_3M & BUBOR_6M \\
\hline Átlag & 8,18 & 5,07 & 6,50 & 7,97 \\
Medián & 7,01 & 3,96 & 5,17 & 5,98 \\
Maximum & 46,13 & 98,08 & 94,34 & 82,48 \\
\hline
\end{tabular}

forrás: MNB, saját szerkesztés

Összehasonlítva a főbb tenorokhoz tartozó napi jegyzések szórásainak a középértékeit, látható, hogy az egynapos tenor rendelkezik a legnagyobb középértékkel (átlag 8,18, medián 7,01 bázispont), ugyanakkor esetében a maximum megközelítőleg csak a fele $(46,13$ 
bázispont) a többi tenor szórásmaximumának. Vagyis az egynapos tenor jegyzéseinek a szórásainál kiemelkedően magas kiugró érték nem tapasztalható. Eltekintve azonban azon kereskedési napoktól, amikor az 1, 3 és 6 hónapos BUBOR-jegyzések kiugró szórást mutattak, az egynapos tenor jegyzései átlagosan nagyobb mértékben szóródnak, vagyis sokkal heterogénebbek.

25. ábra: „W” intézmény egynapos BUBOR jegyzéseinek differencia idősora 2006. január - 2012. június

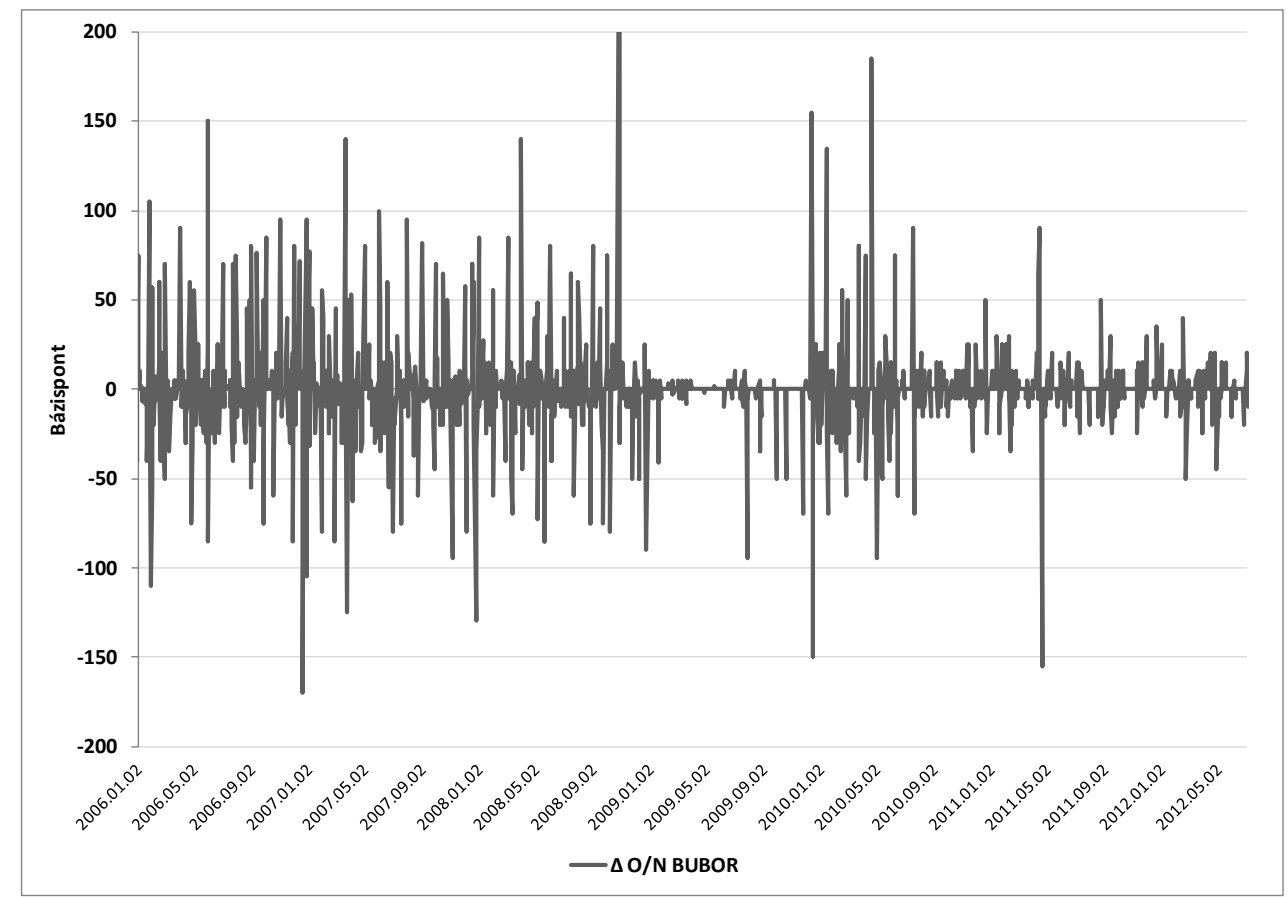

forrás: $M N B$, saját szerkesztés

Megvizsgálva a korábban is bemutatott „W” intézmény egynapos BUBOR jegyzéseinek a differencia idősorát, a 25. ábra alapján látható, hogy az egynapos tenor esetén az intézmény jegyzése sokkal nagyobb mértékben ingadozik, mint a 3 vagy a 6 hónapos jegyzés esetén, mely arra utal, hogy az intézménynek folyamatosan változik az egynapos referencia-kamatról alkotott vélekedése, mely egy mozgásban lévő, aktív piac jeleként értelmezhető.

Azonban a globális válság kitörésekor ezek a jelek szinte elvesztek, 2009 folyamán szinte alig változott a jegyzés szintje, majd 2010-től újra észlelhetőek lettek, azonban az ingadozás szintje sokkal alacsonyabb lett. Ez is megerősíti a fentiekben tett megállapításomat, bár az egynapos BUBOR-tenor a válság után is aktívnak tekinthető. Azonban az aktivitás szintje csökkent az idő előrehaladtával, mely sajnálatos módon pont a kívánt folyamatokkal - az aktivitás növekedésével - ellentétes irányba mutat. 
A leíró statisztika segítségével beláttam, hogy a BUBOR-piac az idő előrehaladtával fokozatosan kiürült. Ezt a folyamatot a 2008-ban Magyarországra is begyürüző globális pénzpiaci válság csak felerősítette. A kiszáradás jelei mind a BUBOR-értékek szintjében, az aktív kamatjegyzők napi jegyzéseinek heterogenitásában és az egyedi jegyzésekben egyaránt tükröződnek. Sőt, ezen túl az egyetlen aktívnak tekinthető - egynapos - tenor esetén is láthatók a BUBOR-piac kiüresedésének jelei.

15. táblázat: Az egynapos BUBOR-jegyzések és a jegybanki alapkamat eltérésének leíró statisztikái bázispontban

\begin{tabular}{|c|c|r|}
\hline & & $\begin{array}{r}\text { O/N BUBOR - } \\
\text { alapkamat }\end{array}$ \\
\hline \multirow{3}{*}{$\begin{array}{c}2006.01 .02- \\
\text { ala }\end{array}$} & $\min$ & -95 \\
\cline { 2 - 3 } & $\max$ & 100 \\
\cline { 2 - 3 } & átlag & $-15,7$ \\
\cline { 2 - 3 } & szórás & 45,1 \\
\cline { 2 - 3 } 2012.06 .30 & medián & -2 \\
\hline \multirow{4}{*}{$2008.10 .27-$} & min & -92 \\
\cline { 2 - 3 } & max & 100 \\
\cline { 2 - 3 } & átlag & $-47,9$ \\
\cline { 2 - 3 } & szórás & 33,0 \\
\cline { 2 - 3 } & medián & -63 \\
\hline
\end{tabular}

forrás: MNB, saját szerkesztés

Az egynapos BUBOR-jegyzések és az alapkamat eltérésének statisztikai értékeit megvizsgálva az egynapos BUBOR-tenor esetében is tapasztalhatunk a válság után a piac száradására utaló jelet. A válság előtti időszakban az alapkamattól vett eltérések mértékének a szórása sokkal magasabb volt $(45,1)$, amely a válságot követő periódusban 30\%-kal csökkent (33,0-ra). Vagyis az egynapos BUBOR alapkamattól vett eltérésének mértéke stabilizálódott, sokkal kevésbé utal egy dinamikusan változó piacra. A középértékek alapján az egynapos BUBOR szintje sokkal egyértelmübben található az alapkamat szintje alatt a válság utáni periódusban, mely a tenorok vizsgálatánál tapasztaltakat figyelembe véve, tartósan - a kezdeti szakaszán - emelkedő hozamgörbére utal.

Azonban ez az egyetlen aktív tenor nem oldja fel az eddig ismertetett problémákat, mivel a BUBOR esetében szabályozói szempontból a legnagyobb szerepe a 3 illetve a 6 hónapos tenornak van, ugyanis a fogyasztói termékek az esetek döntő hányadában ezen két tenor alapján árazódnak át. Így hiába adott a lehetőség, hogy egy aktív tenor esetében a korábban említett hiányosságok nem állnak fenn, és a feltételek adottak lennének fejlettebb módszertanok alkalmazására az elemzésben, az igazán fontos tenorok esetében ez nem segít. 
Véleményem szerint teljes mértékben nem is összehasonlíthatóak az egynapos illetve a 3 vagy 6 hónapos tenor elemzésének eredményei, hiszen teljesen más típusú banki termékekhez is kapcsolódnak, így a következtetések levonásával is óvatosan kell bánni. Az egynapos BUBOR-érték elsősorban nagyvállalati ügyfelek termékeihez köthető, melyek számára sok esetben egyedi árazási formulákat alkalmaznak, ezáltal az ügyletek területén sem törekednek a 100\%-os homogenitásra. Így itt egy sokkal magasabb fokú heterogenitás képes megjelenni a piacon, ami a BUBOR-jegyzésben megjelenik is. A 3 illetve 6 hónapos BUBOR-tenorok esetén azonban erre nincsen lehetőség. Ezt erősíti az a tény is, hogy az ide kapcsolódó fogyasztói termékek többségénél a szabályozó hatóság is elvárja az árazási sztenderditást, és amennyiben nincs aktív bankközi piac ezen lejáratokra, egy nem-manipulált piac esetén ez az egységesítési mechanizmus közvetett módon a referencia-kamat vonatkozó tenorjaiba is begyürüzik.

Ezen tények alapján véleményem szerint a budapesti bankközi forint referencia-kamat jegyzésének vizsgálatánál az egynapos tenor tulajdonságát érdemes bemutatni, de elsődlegesen a fő 3 illetve 6 hónapos tenorra kell koncentrálni.

\subsubsection{Partnerkockázat megjelenése a BUBOR-értékekben}

A korábbi fejezetekben bemutattam, hogy a BUBOR szintjében minimális az eltérés az alapkamathoz képest. 2008 ősze, a válság Magyarországra való begyürüzésének ideje óta, a még korábban meglévő minimális differencia is tovább csökkent. Ekkortól nagyobb különbségek csak nagyon turbulens piaci körülmények között fordultak elő (pl.: 2008. október vagy 2012. január) mikor a forint piacát hatalmas sokkok érték és a közeljövőre vonatkozó várakozásokat is rendkívül nagy bizonytalanságok övezték. Ezért a további vizsgálathoz az idősort 2008. október 22-én kettévágtam és az alapkamattól vett eltérések leíró statisztikáit a 2006. január 2. - 2008. október 21. és 2008. október 27. - 2012. június 30. időszakokra ${ }^{78}$ külön-külön vizsgáltam.

\footnotetext{
${ }^{78}$ A 2008. október 22-ét, mint extrémértéket elhagytam a számszaki elemzésből.
} 
16. táblázat: 3 illetve 6 havi BUBOR-jegyzések és a jegybanki alapkamat eltérésének leíró statisztikái bázispontban

\begin{tabular}{|c|c|r|r|}
\hline & & $\begin{array}{r}\text { 3 havi BUBOR } \\
\text { - alapkamat }\end{array}$ & $\begin{array}{r}\text { 6 havi BUBOR } \\
\text { - alapkamat }\end{array}$ \\
\hline $\begin{array}{c}2006.01 .02 \\
- \\
2008.10 .21\end{array}$ & $\min$ & -24 & -41 \\
\cline { 2 - 4 } & max & 79 & 140 \\
\cline { 2 - 4 } & átlag & 15,3 & 24,7 \\
\cline { 2 - 4 } & szórás & 23,3 & 38,4 \\
\cline { 2 - 4 } & medián & 14 & 22 \\
\hline \multirow{3}{*}{$\begin{array}{c}2008.10 .27 \\
-\end{array}$} & min & -24 & -40 \\
\cline { 2 - 4 } & max & 96 & 103 \\
\cline { 2 - 4 } & átlag & 10,3 & 14,0 \\
\cline { 2 - 4 } & szórás & 15,8 & 23,9 \\
\cline { 2 - 4 } & medián & 10 & 10 \\
\hline
\end{tabular}

forrás: MNB, saját szerkesztés

A leírós statisztikákból kiolvasható, hogy a 2008 októbere óta a BUBOR-értékek átlagosan sokkal kisebb mértékben térnek el az alapkamattól. A szélső értékek nem változtak, az eltérések maximuma 2,5-3-szorosa a minimumok abszolút értékének. 2008 után a középértékek csökkentek. Mind a számtani átlag, mind a medián alacsonyabb lett. A 6 havi BUBOR alapkamattól vett eltérése esetén a számtani átlag csökkenése meghaladja a 40\%-ot (24,7-ről 14-re). A medián érték mindkét jegyzési idő (tenor) alapkamattól vett eltérése esetén 10-re csökkent. A 6 havi értékeknél ez több mint 50\%-os csökkenés. A szórások csökkenése szintén arra utal, hogy a második időszakban a jegyzések még kevésbé tértek el a jegybanki alapkamattól, vagyis csökkent a BUBOR-ban megjelenített további információk súlya. E megállapítás részben ellentétesnek tűnhet a PSZÁF által publikált tanulmánnyal (Fliszár [2013]), ahol a korrelációk vizsgálatán keresztül a többlet piaci információk megnövekedése lett megállapítva. Azonban a korreláció az együttmozgást ragadja meg, és nem veszi figyelembe a BUBOR és az alapkamat eltérésének mértékét. A felügyelet megállapítása a statisztikai adatok alapján azt mutatja meg, hogy az eltérés mértéke folyamatosan változott, így tényleg új információk jelentek meg vagy kerültek ki a jegyzésből, azonban a 16. táblázat alapján a válság után átlagosan az információk kikerülése olvasható le.

A fentieknek egyik mozgatója a bankközi fedezetlen forint termékek piacának további szükülése. A válság következtében az intézmények még jobban visszaszorították ez irányú tevékenységüket. A hiteltermékekben a devizahitelezés visszaszorulásával egyre jobban megnőtt a BUBOR szerepe, így a referencia kamatlábat elhagyni nem lehetett, ugyanakkor valamilyen elvek vagy benchmark alapján meg kellett határozni a termékeket, még ha valós ügyletkötés az 1-napos, hetes tenorok kivételével nem igazán állt rendelkezésre. Ez a 
benchmark érték az alapkamat lett, amire a turbulensebb időszakokban a swap kamatszintek hatást gyakoroltak, de mint azt korábban is szemléltettem, ezen hatások általában pár napon belül elhaltak és a BUBOR-értékek visszakonvergáltak az alapkamat szintjéhez.

Fontos hangsúlyozni, hogy a BUBOR esetében fedezetlen bankközi termékről beszélünk, így a piacon lévő szereplőkhöz kapcsolódó partnerkockázatok megítélése is befolyásolja a piaci aktivítást. A partnerkockázatok jelentős növekedésével a szereplők a fedezett termékek felé fordulnak el és kevésbé preferálják a fedezetlen termékeket. A BUBOR-piacon szereplő bankok esetében nincs univerzális mutatószám, mely egyben teljes körüen jellemezné a saját partnerkockázatuk alakulását, ezért elemzésemben az 5 éves magyar CDS felárhoz viszonyítom a 3 havi BUBOR - alapkamat szpred alakulását.

26. ábra: A 3 havi BUBOR - alapkamat szpred és magyar CDS felár idősor 2006. január - 2012. június

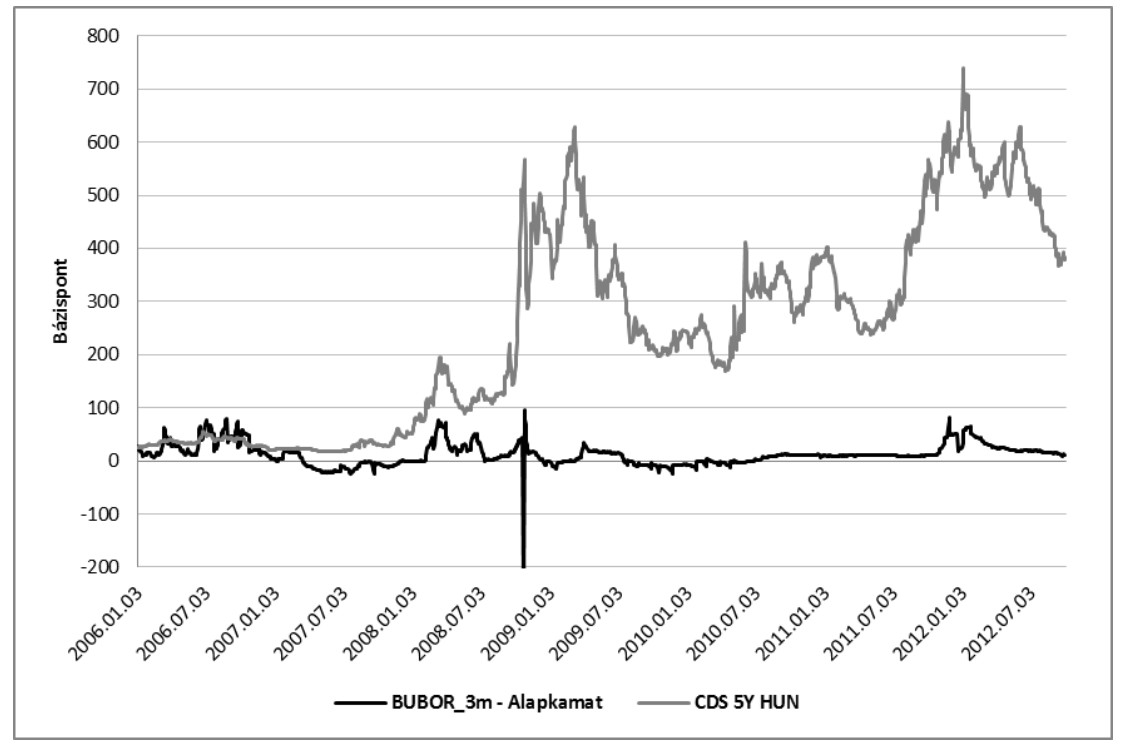

forrás: MNB és Bloomberg, saját szerkesztés

A 25. ábrán tisztán látható, hogy a válság 2008. októberi Magyarországra való begyürüzése után a CDS felár szintje jelentősen és tartósan megnövekedett, míg a BUBOR - alapkamat szpred összehúzódott. A szpred csak a 2011. december - 2012. január közötti periódusban nyílt ki, mikor rövid időn belül két 50 bázispontos alapkamat emelés történt. Ekkor a szpred értékek láthatóan a piaci szereplők partnerkockázat is tükrözni kezdték. Ugyanis a BUBORértékeknek csak egy mozgatórugója a bankközi fedezetlen forint termékek piacának kiszáradása, és - mint a 25. ábrán is látható - egyes esetekben a piaci szereplők saját partnerkockázatának a megítélése is képes befolyásolni a BUBOR szintjét. Ez utóbbinak azonban nem egyenes következménye a fedezetlen bankközi forint termékek piacának arányos szükülése. 


\subsection{A bankok által jelentett BUBOR-értékek lehetséges anomáliáinak statisztikai modellezése ${ }^{79}$}

A statisztikai elemzés három fő részből áll.

i. Az elsőben az egyes intézmények valós jegyzéseit hasonlítom össze relatív távolságmértékek alapján, ami azt mutatja meg, hogy mennyire hasonlóak illetve eltérőek a jegyzési viselkedések.

ii. A másodikban a meglévő információk alapján becslem az intézmények jegyzési viselkedését. Itt arra próbálok következtetni, hogy az adott intézménynek mely kereskedési napokon kellett volna a jegyzésben azonos viselkedést mutatnia, majd a becsült eredményeket összevetem a valós eredményekkel.

iii. Végül a harmadik részben a becsült intézményi viselkedéseket hasonlítom össze az első részben is alkalmazott módszertannal.

Az elemzés célja annak megállapítása, hogy egy adott intézmény által napi szinten jelentett 3 illetve 6 havi BUBOR-értékek az aktív jegyzőbankok által jelentett átlagos értékhez képest (a nyesés nem kerül figyelembevételre) valamilyen szisztematikus viselkedést mutatnak-e, ha figyelembe vesszük a rendelkezésre álló intézményi adatokat a főbb piaci indikátorok mellett.

A statisztikai vizsgálatom során a jegyzést végző kereskedők viselkedését befolyásoló információkat vettem alapul. Ezen információk két csoportba sorolhatók: piaci, illetve intézmény-specifikus információkra. A piaci információkat a jegyzést végző személy elöre nem ismeri, de egy adott nap eseményei hosszabb távon kihathatnak a döntésére. Ezért egy kereskedési nap jegyzésének a vizsgálatánál a piaci információkat megjelenítő változók esetén az elmúlt 20 kereskedési nap értékét vettem figyelembe. Vagyis azt feltételeztem, hogy egy piaci esemény egy hónapig befolyásolja a kereskedő viselkedését.

Az intézmény-specifikus változók esetén a jövőbeli 20 kereskedési nap értékét vettem alapul. Itt azt feltételezem, hogy a kereskedő tisztában van az intézmény határidős termékeinek lejárati szerkezetével, illetve a fedezeti szükségletekkel, és így a biztos jövőbeli események kihathatnak az adott napi viselkedésére.

\footnotetext{
${ }^{79}$ Hiányos adatok miatt nem készült egyedi statisztikai modell három bank esetén. Egy bank nem rendelkezik derivatív pozícióval, ezért a becslés során esetében csak a közös változókat alkalmaztam. Az adathiány miatt a három intézmény becslése megegyezne a hivatkozott bank becslésével, az áttekinthetőség érdekében azonban csak ez utóbbit szerepeltetem az elemzésben.
} 
Az elemzés során nem az átlagos jelentett BUBOR-tól való pontos eltérést, hanem az eltérés irányát vizsgálom, vagyis azt, hogy az intézmény adott körülményekhez tartozó viselkedésében tapasztalható-e valamilyen szisztematikusság, mikor jegyez az átlag felett vagy alatt.

Ez gyakorlatilag egy lefelé irányuló skálázás a modellezésben, mely információvesztést jelent. Esetünkben azonban nehezen elképzelhető, hogy egy esetleges szisztematikusság esetén az eltérések valamilyen matematikai formulát követnének, ezért elégséges, ha a jelentett értéknek az átlagos értékhez való viszonyát próbálom megbecsülni. Vagyis a magyarázott változónak elégséges az átlagos BUBOR-jegyzéshez való viszonyt tükröznie.

A modellezés során a K-középpontú klaszterelemzést alkalmaztam és a 2009. február $2 .^{80}$ 2012. június 29. közötti kereskedési napokat (mint megfigyeléseket) soroltam három klaszterbe, vagyis a modell arra ad becslést, hogy egy adott kereskedési nap viselkedésének melyik más napokhoz hasonló viselkedést kellene megjelenítenie. A felhasznált változók az intézmények rendelkezésére álló információkat próbálják tükrözni:

17. táblázat: A statisztikai modellezés során felhasznált nyers változók

\begin{tabular}{|c|c|c|}
\hline & & Leírás \\
\hline 1 & EUR & EUR/HUF MNB középárfolyam (forrás: MNB) \\
\hline 2 & $\mathrm{CHF}$ & CHF/HUF MNB középárfolyam (forrás: MNB) \\
\hline 3 & USD & USD/HUF MNB középárfolyam (forrás: MNB) \\
\hline 4 & CDS & Magyar 5-éves CDS felár (forrás: Bloomberg) $^{81}$ \\
\hline 5 & swap3M/swap6M & $\begin{array}{l}3 \text { illetve } 6 \text { havi forint IRS swap értékek (forrás: } \\
\text { Bloomberg) }\end{array}$ \\
\hline 6 & FRA3x6/FRA6x12 & Forint FRA értékek (forrás: Bloomberg) \\
\hline 7 & Alapkamat & Jegybanki alapkamat mértéke (forrás: MNB) \\
\hline 8 & DKJ & 3-hónapos DKJ hozama (forrás: MNB) \\
\hline 9 & HUFONIA & HUFONIA értékek (forrás: MNB) \\
\hline 10 & int_3M/int_6M & $\begin{array}{l}3 \text { illetve } 6 \text { havi BUBOR szerint átárazódó } \\
\text { intézményi szintű nettó nyitott derivatív pozíciók } \\
\text { (forrás: MNB) }\end{array}$ \\
\hline
\end{tabular}

\footnotetext{
${ }^{80}$ A becslés során korlátot jelentett, hogy az intézmény-specifikus változó adatsora csak 2009 januárjától állt rendelkezésemre. Ebből kifolyólag a statisztikai becslést csak a fenti időszak esetén végeztem el.

813 illetve 6 hónapos jegyzések vizsgálatánál egy 5 éves termék adatsorának választása modellezés szempontjából következetlennek tűnhet, de a partnerkockázatról szóló fejezet alapján a jegyzést végző szakértők az adott napi referencia-érték kialakításánál az 5 éves CDS felárat is figyelembe veszik. Ezen megállapítást a klasztermodell is megerősítette, hiszen a 17. táblázat alapján mindkét tenor esetén szignifikánsnak bizonyult.
} 
A piaci volatilis időszakok megragadása érdekében a fenti idősorok esetén transzformált változókat alkalmaztam. Az első kilenc változó esetében az alkalmazott képlet (5.1):

$$
x_{i}^{\text {transzformált }}=\sum_{t=1}^{20} w_{t} \frac{x_{i-t}}{\bar{x}}
$$

Ahol $\mathrm{w}_{\mathrm{t}}$ a $\lambda=0,8$ paraméterü exponenciális súlyozás adott értékei. A transzformáció során az elmúlt 20 kereskedési nap adatait vettem figyelembe. Az így kapott változó a piaci volatilitás mellett a növekvő illetve a csökkenő tendenciákat is figyelembe veszi.

A nettó nyitott pozíciók esetén viszont előretekintést alkalmaztam, mivel az intézmények a könyveikben előre látják a lejáró pozíciókat illetve az esetlegesen fellépő igényeket, így a jövőbeli ismert változások kihathatnak a jelenbeli döntéseikre. Exponenciális súlyozást $\left(\mathrm{w}_{\mathrm{t}}\right)$ alkalmazva a transzformáció képlete (2):

$$
x_{i}^{\text {transzformált }}=\sum_{t=1}^{20} w_{t}\left(x_{i+t}-\bar{x}\right)
$$

Látható, hogy több más változó alkalmazása is felmerült az elemzés kezdeti szakaszában, de az intézmény-specifikus változók alacsony számossága miatt a változók egy részét a változók közötti szoros korrelációk (CHF, USD, Alapkamat, DKJ) illetve szakértői megállapítások (HUFONIA) alapján kiszürtem. A kezdeti szakaszban figyelembe vett változók korrelációs mátrixát (a transzformált változók közötti korrelációs mátrixot) a 8.4. Melléklet tartalmazza.

Az aktív jegyző intézmények esetén két-két klaszterező modell készült, melyben a felhasznált változókat a következő táblázat mutatja ${ }^{82}$ :

18. táblázat: A K-közép klaszterezés során felhasznált változók

\begin{tabular}{|c|c|}
\hline „A' modell & „B” modell \\
\hline EUR & EUR \\
CDS & CDS \\
swap3M & swap6M \\
FRA3x6 & int_6M \\
int_3M & \\
\hline
\end{tabular}

\footnotetext{
${ }^{82}$ A második modellből az FRA-értékeket szakértői megfontolások alapján elhagytam. A hat hónapon felüli tenoroknál szignifikánsan növekszik a swap-értékek szerepe. Emellett a hathónapos jegyzésnél az FRA értékek hozzáadott információja is jelentősen lecsökken. A változó elhagyásával intézményenként jóval eltérőbb struktúrák adódtak.
} 
A modellenként kapott klaszterbesorolásokat összevetettem az intézmények 3 illetve 6 havi jegyzéséből definiált ún. kontrollváltozóval. A kontrollváltozó definíciója modellenként a következő volt:

\section{9. táblázat: A kontrollváltozó definíciója}

\begin{tabular}{|l|l|}
\hline \multicolumn{1}{|c|}{ "A" modell } & \multicolumn{1}{c|}{ "B' modell } \\
\hline 1, ha $\mathrm{y}_{\text {int_3m }}>\mathrm{y}_{\text {avg_3m }}+0,05$ & 1, ha $\mathrm{y}_{\text {int_6m }}>\mathrm{y}_{\text {avg_6m }}+0,05$ \\
0, ha $\mathrm{y}_{\text {avg_3m }}+0,05 \geq \mathrm{y}_{\text {int_3m }} \geq \mathrm{y}_{\text {avg_3m }}-0,05$ & 0, ha $\mathrm{y}_{\text {avg_6m }}+0,05 \geq \mathrm{y}_{\text {int_6m }} \geq \mathrm{y}_{\text {avg_6m }}-0,05$ \\
-1, ha $\mathrm{y}_{\text {int_3m }}<\mathrm{y}_{\text {avg_3m }}-0,05$ & -1, ha $\mathrm{y}_{\text {int_6m }}<\mathrm{y}_{\text {avg_6m }}-0,05$ \\
\hline
\end{tabular}

Vagyis az adott tenorra vonatkozóan azt jelenítettem meg, hogy az intézmény az átlagos értéknél magasabb vagy alacsonyabb értéket jegyzett az adott kereskedési napon. A +/- 5 bázispontos szürke zóna az átlagos jegyzések besorolására szüknek tünhet, de nagyobb eltérés alkalmazása esetén a napi jegyzések meglehetősen alacsony szórása miatt (a kereskedési napok döntő többségén a szórás a 15 bázispontot sem éri el) sok intézmény esetén a +1 illetve -1-es kategóriák alacsony elemszámúak lehetnek. Ez az alacsony szórás is indokolja, hogy a szürke zónát nem a nyeséssel kialakított BUBOR-értékhez viszonyítottam, hanem az összes napi jegyzés átlagához, vagyis azt az információt jelenítettem meg, hogy mikor tért el egy adott intézmény az átlagos napi viselkedéstől.

A kapott eredményeket intézményenként kereszttáblában összevetettem a kontrollváltozóval, melyeket a következőkben intézményenként áttekintettem ${ }^{83}$.

\subsubsection{Tényadatok - tapasztalt viselkedés}

Első lépésként a kontrollváltozók egymáshoz való viszonyát vizsgáltam. A kontrollváltozók vizsgálatával a célom az intézményi tény viselkedési struktúrák összehasonlítása. Ehhez az intézményi szintü adatokat hierarchikusan klasztereztem. A klaszterezés eredményeként kapott dendrogam segítségével arra keresem a választ, hogy azonosíthatók-e intézmények, melyek a referencia-kamat jegyzésénél hasonlóan reagálnak a piaci környezet változására.

Mivel a változóink ordinálisak (az intézmény jegyzése átlag alatti, átlagos vagy átlag feletti), távolságmértékként khi-négyzetet alkalmazta ${ }^{84}$. Az összevonó eljárások közül a legtávolabbi szomszéd elvet választottam. E megközelítés tulajdonsága, hogy két klaszter távolsága a

\footnotetext{
${ }^{83}$ Az ANOVA táblák F-tesztjének p-értéke 0,000 volt minden változóra az összes intézményi futtatás esetén.

${ }^{84}$ Másik megoldás lehet a kategóriaváltozók bináris változókká transzformálása. Lsd. pl.: Rezanková, H. (2009). Cluster analysis and categorical data, Statistika, 216-232.
} 
klaszterek legtávolabbi elemeinek a távolsága alapján adódik. Az alkalmazás különösen érzékeny az outlierekre, hiszen a legtávolabbi elemekből indul ki ${ }^{85}$.

Az 5.3. és 5.4. fejezetek elemzései is alátámasztják, hogy a napi jegyzések szórása nagyon alacsony, illetve a jegyzési idősorokon sem láthatók tartós egyirányú eltérések. Ezek alapján nem feltételezek kiugró értékeket, vagyis célszerü a legtávolabbi szomszéd elv választása, ugyanis így jobban elkülönülnek az egyedi eltérések. Az „A” ill. „B” modell kontrollváltozói esetén az alábbi összevonások adódtak:

27. ábra: 3 hónapos BUBOR-jegyzésekből készített kontrollváltozók dendrogramja

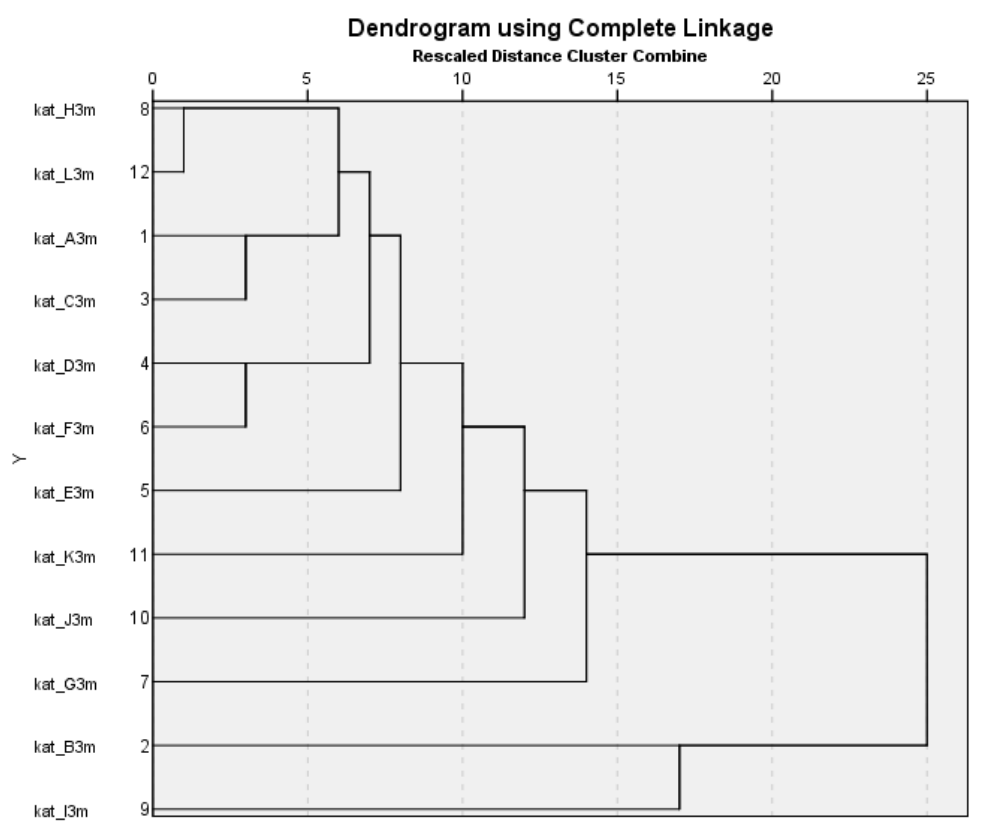

A dendrogram a relatív távolsági szinteket jelenítik meg (25-ös skálára arányosítva). Az ábrák értelmezésére, a klaszterek megfelelő számát meghatározó vágás helyének meghatározására, hüvelykujj szabály nincsen ${ }^{86}$, de az elemzési gyakorlatban 5-10 közötti értékekből indulnak ki, melyet én is követek a következtetések levonása során.

A 3 hónapos BUBOR-jegyzések vizsgálatánál látható, hogy az intézmények viselkedésénél 8-9-es vágási szintnél - egy csoport („H”, „L”, „A”, „C”, „D”, „F” és „E” bank) valamint öt külön bekapcsolódó („,K”, „J”, „G”, „B” és „,” bank) megfigyelés adódik. Vagyis a szektor többi szereplöjétől eltérő viselkedést jelenített meg öt hazai intézmény. A csoporton belül látható a „E” bank elkülönülése. A „B” és az „I” bank legtávolabbi besorolása alátámasztja a

\footnotetext{
${ }^{85}$ Mooi, E. - Sarstedt, M.: A Concise Guide to Market Research, The Process, Data, and Methods Using IBM SPSS Statistics, 2011, Springer

${ }^{86}$ Kovács E.: Pénzügyi adatok statisztikai elemzése, 2011, Tanszék kft. 56. o.
} 
tapasztalatokat, melyek alapján a viselkedésüknél más aspektusokat is figyelembe vesznek. Tehát statisztikailag is igazolható, hogy a két intézmény viselkedése nem mutat összehangoltságot. Fontos hangsúlyozni, hogy a két intézmény távoli kapcsolatából az eltérő müködési struktúra is kidomborodik.

28. ábra: 6 hónapos BUBOR-jegyzésekből készített kontrollváltozók dendrogramja

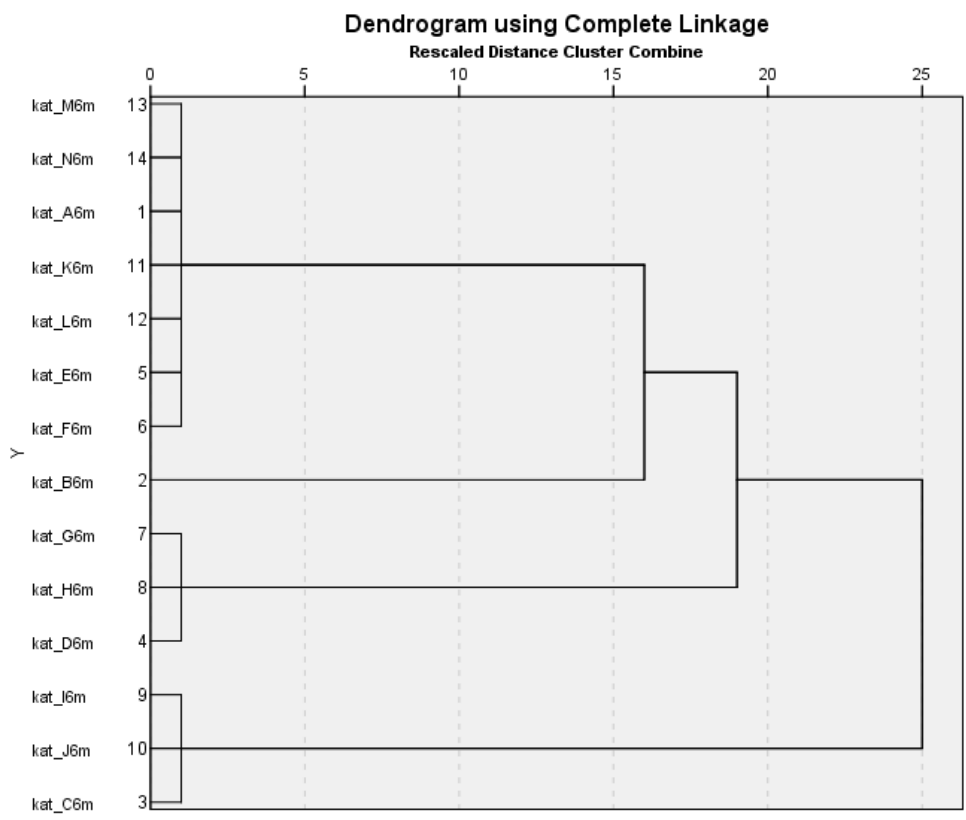

A 6 hónapos jegyzéseket vizsgálva azonban ettől részben eltérő kép alakul ki. Ennek fő oka, hogy a 6 hónapos jegyzésnél nagyobb hangsúlyt kapnak a jövőre vonatkozó vélekedések (pl. egy lehetséges alapkamat-változásról), így megváltozhatnak az intézmények viselkedése közötti kapcsolatok. A dendrogramról látható, hogy a „B” bank viselkedése mindenki mástól eltérő. Ugyanakkor a többi intézmény viselkedése három csoportba sorolható („G”, „H” és „,D” bank; „I”, ,J”, és,,C” bank; „,M”, „N”, „A,, ,K”, „L”, „E” és „F” bank).

Azonban érdekes kérdés lehet, hogy találhatók-e olyan megállapítások az aktív kamatjegyzők viselkedési struktúráira, melyek mindkét vizsgált tenor esetén relevánsak. A 27. és 28. ábra alapján leolvasható közös viselkedési struktúrák:

• „B”, „I” és „J” bank jegyzése elkülönül a többi piaci szereplőtől mindkét tenor esetén;

- „D” és „G” bank viselkedése hasonló;

- a derivatív piacon kevésbé aktív bankok viselkedése nem tér el jelentősen ${ }^{87}$;

\footnotetext{
${ }^{87} \mathrm{Az}$ elemzés anonimizálása miatt a fenti állítás kizárólag a klaszterelemzés és a tanulmányban feltüntetett eredményekre nem indokolható. Itt az állítás fenntartásánál az MNB honlapján elérhető elemzésre támaszkodok (Fliszár [2013]).
} 


\subsubsection{Egyedi intézményi adatok - tény versus becslés ${ }^{88}$}

Az előzőekben leírt viselkedést megpróbáltam a rendelkezésre álló információk alapján statisztikailag is becsülni a fentebb hivatkozott klasztermodellel. Egyszerüsítve a kereskedési napokat három kategóriába soroltam. A kapott besorolásokat mind a 3, mind a 6 havi jegyzések esetén összevetettem a tényadatokkal (kontrollváltozó) ${ }^{89}$. Az összevetések részletes eredményét tartalmazó kereszttáblák a 8.5. Mellékletben találhatók. A kereszttáblák segítségével arra próbálok következtetni, hogy valamely klaszter mefeleltethető-e a kontrollváltozó valamely kategóriájának. Ez azt jelentené, hogy az intézmény jegyzési viselkedésének egyes elemei egyértelműen beazonosíthatók (például nagy valószínűséggel a többi piaci információt ismerve megmondható, hogy az intézmény az adott napon átlag alatti értéket jegyez. Intézményi szinten az alábbi eredmények adódtak ${ }^{90}$ :

- „A" bank

○ $\mathrm{Az}$ „F” bankhoz hasonló jegyzési viselkedést mutat, a kereskedési napok többségén átlagod vagy átlag alatti jegyzéssel. Az átlag feletti jegyzések száma 2009-től kezdve minimális, mindössze a vizsgált kereskedési napok 4,8\% (3 havi) illetve 7,1\%-án (6 havi) jegyzett átlag feletti értéket. Mind a 3, mind a 6 havi becslés esetén az „a” klaszter elemszáma jelentősen alacsonyabb - a 6 havi becslésnél mindössze 33 elemü. A másik két klaszter esetében a tényjegyzés arányok adódnak vissza, vagyis egyik klaszter sem feleltethető meg valamely kontrollváltozó kategóriának.

- „B” bank

○ „B” bank tényjegyzéseinél az átlagos jegyzések mellett mind a 3 havi, mind a 6 havi tenor esetén a lefelé húzó hatás jelenik meg benne. A vizsgált kereskedési napok 22,2\% illetve 28,8\%-án jegyzett átlag alatti értéket, míg átlag felettit csak 17,7\% illetve 16,2\%-án. A becsült klaszterek esetén egyik

\footnotetext{
${ }^{88}$ Az eredmények értékelésénél az autokorrelációs hatást figyelembe vettem, azonban az előző pontban említett kiszáradt piac probléma miatt, nem áll rendelkezésre megfelelő mennyiségü és minőségü információ egy az autokorrelációt is kezelő, elfogadható magyarázó erővel rendelkezö ökonometriai modell kialakításához. Az egyedi intézményi eredmények értelmezése néhány esetben a szerző intuícióját is tükrözik.

${ }^{89} \mathrm{Az}$ összevetésnél az 8.5. Melléklet ábrái is felhasználásra kerültek. A melléklet ábrái a 2006. január -2012. június közötti időszakban ábrázolják intézményenként az intézményi jegyzés és az adott napi BUBOR érték eltérését. A pozitív érték azt mutatja, hogy az adott kereskedési napon az intézmény jegyzése meghaladta a BUBOR értéket.

${ }^{90} \mathrm{Az}$ „M” és az „N” bank esetében csak a hat hónapos tenorra készült becslés, melynek oka a 3 hónapos BUBORhoz kötött nettó pozíciók marginalitása. Ennek eredményeképpen a 3 hónapos becslés szinte megegyezett volna a korábban hivatkozott benchmark becslésénél kapott osztályozással.
} 
klaszter sem feleltethető meg valamely kontrollváltozó kategóriának, vagyis nem azonosíthatók egyértelmúen viselkedési elemek.

- „C' bank

○ A jegyzéseknél a 2009-től kezdődő időszakban az átlagtól való eltéréseknél dominancia nem látható. Mindösszesen két kereskedési nap volt 50 bázispontnál nagyobb eltérés a jegyzésben (egy-egy fel- illetve lefele irányuló jegyzés). A 3 havi BUBOR jegyzéseinek 68\%-a az átlagos kategóriában található. A becslés során kapott klaszterekhez tulajdonságok nem rendelhetők, szinte arányosan fordulnak elő az átlagtól eltérő jegyzések. A klaszterezés eredményei alapján egy kategória szinte kiürül (a 6 havi jegyzés esetén mindösszesen 14 elem kerül bele). Ez arra utal, hogy az információk alapján mindössze két klaszterbe sorolódnak az elemek, és a kontrollváltozó által definiált hármas tagolás becslése nem lehetséges.

- „D” bank

- A bank a volatilis időszakokban tért el jelentősebb mértékben a napi jegyzésektől elsődlegesen negatív irányban. Ez annak köszönhető, hogy a piaci turbulenciákat később, vagy első lépésben a többi piaci szereplőtől kisebb mértékben követte. Ez az óvatos magatartás enyhén megjelenik a klaszterelemzés eredményében, ugyanis mindhárom klaszterben az átlagos jegyzések vannak többségben. A felfelé irányuló jegyzések $60 \%$ illetve $70 \%$ át tartalmazó klaszter (,a”) tekinthető átlag felé húzó klaszternek, azonban a klaszter elemeinek mindössze 27,2\% illetve 39\%-át adják az átlag feletti kereskedési napok. Ennek alapján viselkedési struktúra nem azonosítható, azonban annyi megállapítható, hogy amennyiben egy kereskedési nap ide esik, a ténynél nagyobb az átlag feletti jegyzés valószínűsége.

- „E” bank

○ Kizárólag csak a közös piaci változókat használtuk fel a becslés során. Mivel nincsen egyedi (BUBOR-hoz kötött derivatív állományokról) információ, ezért ebből kifolyólag a banknak nincs motivációja az átlagos értéktől való eltérésre, melyet mind a tény, mind a becsült adatok is visszaigazolnak. A bank a vizsgált 861 kereskedési napból mindkét tenor esetén megközelítőleg 700 alkalommal jelentett átlagos értéket. A bank jegyzése mindössze három 
kereskedési nap (2008 ősz - 2009 tavasz közötti időszakban) tért el legalább 50 bázisponttal a napi referencia-értéktől. A jegyzések jellemzően a +/- 20 bázispontos sávon belül mozogtak. A kapott klaszterek nem azonosíthatók be egyik valós kategóriának sem, ugyanis a kontrollváltozó értékei szerinti eloszlásuk szinte megfelel a valós arányoknak.

- „F” bank

○ A bank jegyzései átlagtól való eltérés esetén jellemzően lefelé térnek el. Ez a becsült klaszterek esetében tapasztalható. A kapott három klaszter közül kettőben gyengébben, a harmadikban határozottabban jelentkezik az átlag alatti jegyzések hatása. A harmadik klaszter esetében 50\%-ot meghaladja az átlag alatti jegyzések aránya, vagyis amennyiben egy kereskedési nap ezen klaszterbe esik, „F” bank nagy valószínüséggel átlagos vagy átlag alatti BUBOR-értéket jegyez, az átlag feletti jegyzés valószínűsége alacsony (6,3\% illetve $13,6 \%$ ).

- „G” bank

○ A bank jegyzésében a 2009 tavaszi időszakot leszámítva (két kereskedési nap kivételével) nincsenek jelen a kiugró eltérések az átlagos értéktől. Ilyen hatást a klaszterezés során sem lehetett azonosítani, hiszen mindkét vizsgált tenor esetén a kapott klasztereken belüli kategória megoszlások szinte visszaadják a valós viselkedési eloszlást, így átlag felé vagy alá jegyzés felé húzó klaszter sem azonosítható.

- „H” bank

○ A vizsgált időszakban a „H” bank a 3 és 6 havi tenor esetén 666 illetve 578 (a 861-ből) kereskedési nap átlagos értéket jegyzett. A további kereskedési napok többségén pedig jellemzően átlag alatt értéket rögzített. Kiemelendő, hogy a hivatkozott időszakban a BUBOR és a bank jegyzésének különbsége egyetlen kereskedési nap sem haladta meg az 50 bázispontot. A becslésnél kapott klasztereknél mindösszesen ez a tendencia figyelhető meg, további beazonosítás csak nagyfokú bizonytalanság mellett lenne lehetséges. 
- „I” bank

○ Az „I” bank a vizsgált időszakban szinte alig jelentett átlag alatti kategóriában, melyet az 8.6. Melléklet kapcsolódó ábrája is alátámaszt. A 3 illetve 6 hónapos jegyzés becslésénél szintén megjelenik az átlag felé húzás. A kapott besorolások alapján a 3 hónapos becslésnél két (,a” és „c”), míg a 6 hónapos becslésnél mindhárom klaszter átlag felé húzónak tekinthető. A 3 havi tenorra vonatkozó klaszterezésnél a „,b” klaszterben az átlagos jegyzések aránya 76\%, így emennyiben egy kereskedési nap ide sorolódik nagy valószínüséggel átlagos jegyzés párosul hozzá.

- „J” bank

○ A bank jegyzései sok esetben eltérnek az átlagos értékektől, de az eltérések néhány kereskedési nap kivételével 20 bázisponton belül maradnak (8.6. Melléklet vonatkozó ábrája alapján). Az átlag feletti illetve alatti jegyzések száma sem különbözik jelentősen. Ezzel mutat összhangot a becslés is, hiszen mindhárom klaszter viszonylag nagy elemszámúnak tekinthető. A két legnagyobb elemszámú klaszterben a kontrollváltozó kategóriáinak eloszlása alapján a 3 havi tenor esetén átlag feletti, míg a 6 havi tenor esetén enyhén átlag alatti jegyzés valószínűsíthető, amennyiben az intézmény nem átlagos értéket jegyez.

- „K” bank

○ Szinte az összes megfigyelést egy illetve két klaszterbe sorolta a modell. Ettől azonban a bank valós viselkedése sem tért el jelentősen, hiszen mindössze három kereskedési nap jegyzett 25 bázispontnál nagyobb eltéréssel a napi BUBOR-hoz képest és ezekben az esetekben is kizárólag negatív irányban. A klaszterezés eredményei alapján viselkedési elem nem azonosítható.

- „L" bank

○ A jegyzésénél nem jellemzők a kiugró eltérések. Az „L” bank viselkedésben egy gyenge felfelé húzó hatás tapasztalható. Ez a hatás a két legnagyobb elemszámú klaszter esetében is szembetűnő minkét vizsgált tenor esetében. A 6 havi tenor esetében például a két legnagyobb elemszámú tenor esetén az 
átlag feletti jegyzés valószínűsége 6- illetve 2-szerese az átlag alatti jegyzésnek.

- „M” bank

○ A klaszterek nem azonosíthatók be egyértelmúen, irányultsági hatások sem olvashatók le. A bank valós viselkedése is elég szélsőségkerülőnek tekinthető. 2009-től kezdődő időszakban mindösszesen két kereskedési nap tért el legalább 20 bázisponttal a napi BUBOR-értéktől. A legnagyobb elemszámú klaszterben az átlagos jegyzések aránya 69\%.

- „N” bank

○ A bank jegyzéseinél felfelé húzó hatás figyelhető meg. Amennyiben az intézmény átlagtól eltérően jegyez, kétszer akkora a valószínűsége a múltbeli adatok alapján a felfelé jegyzésnek. 2012 januárjában tartósan eltérő jegyzés is előfordult. Ez a hatás a klaszterezésnél is tapasztalható, hiszen az egyik kapott klaszterben az átlagos jegyzések mellett szinte csak felfelé eltérő jegyzések találhatók.

Az egyedi intézményi viselkedések becslését összefoglalva megállapítható, hogy éles viselkedési struktúrák nem azonosíthatók, vagyis nem jutottam olyan szintủ eredményre, mely adott intézmény esetén egy kereskedési napról adott esetben megmondaná, hogy milyen típusú jegyzés fog történni az adott napon. Egyes klaszterek esetében csak arra kapunk információt, hogy a ténynél nagyobb vagy kisebb az átlag alatti/átlagos/átlag feletti jegyzés valószínüsége.

A kapott eredmények megfelelnek a várakozásomnak, hogy nem azonosítható egyértelmű viselkedési struktúra. Ez azt is mutatja, bár a BUBOR-jegyzés több hiányossággal rendelkezik, a szakértői vélemények igenis megjelennek benne, és egy analitikus képlettel nem helyettesíthető.

\subsubsection{A becslés eredményeinek összevetése}

A klaszterelemzési eredmények validitásának ellenőrzésére a tényadatoknál (kontrollváltozó) is alkalmazott elemzést (legtávolabbi szomszéd elv, khi-négyzet) a kapott klaszterbesorolásokra is elvégeztem.

A fenti módszertan alkalmazásához azonban két közgazdasági feltételezésből indultam ki: 
- a klaszterek kategóriái megfeleltethetők átlag alatti, átlagos, átlag feletti jegyzéseknek, vagyis a nominális skálát átrendezéssel ordinálissá alakíthatjuk;

- mivel egyedi intézmény-specifikus információt csak egyetlen változó hordozott, így várhatóan a besorolt elemek kb. 60-70 \%-a az ,átlaghoz való viszonyban” megegyezik.

A felsorolt érvekböl kiindulva elöször a kapott klaszterbesorolásokat átkódoltam, így a megfigyelések döntő többsége két intézmény eredményét szemléltető klasszifikációs táblában az átlóba esett. Végezetül pedig az összes intézményi klaszterezést figyelembe véve a kategóriakódolást úgy alakítottam, hogy a középső klaszter jelentse az átlagos értékeket. A leírt kétlépéses transzformációval a nominális skálán mért változóinkat ordinálissá alakítottam. Ezek alapján az elemzést a kontrollváltozó elemzéséhez hasonlóan végezhetjük.

29. ábra: „A” modell ( 3 M) eredményének dendrogramja

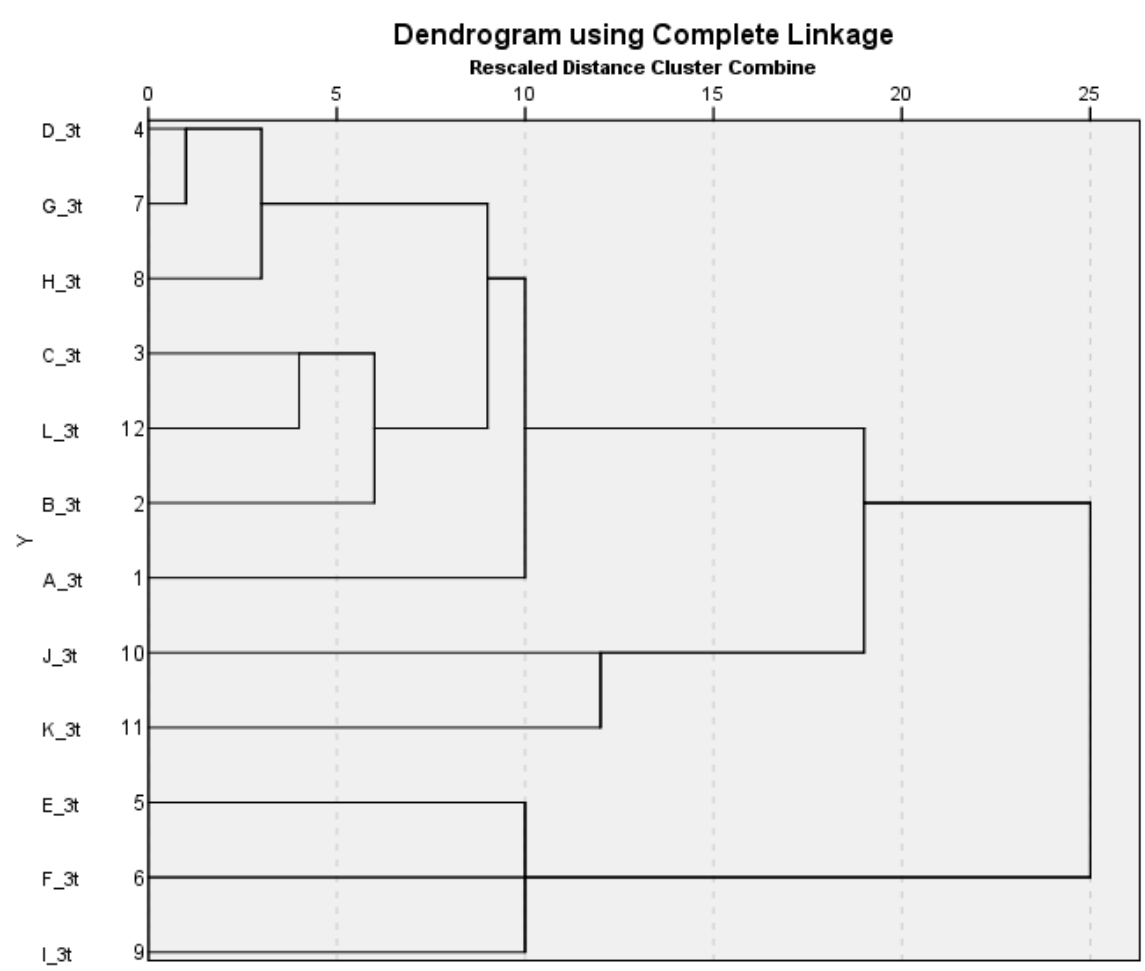




\section{0. ábra: „B” modell (6 M) eredményének dendrogramja}

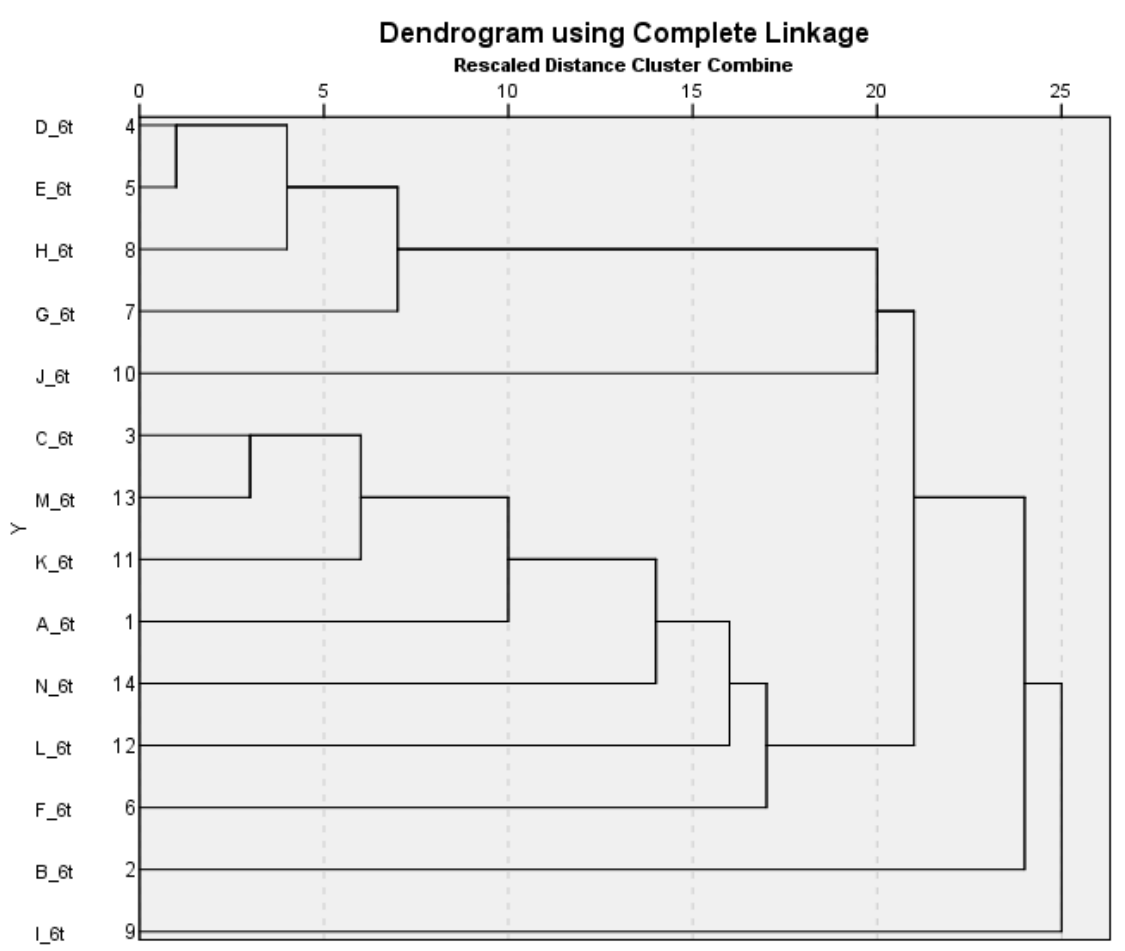

A 30. és 31. ábrán látható, hogy a 3 illetve 6 havi jegyzések esetén eltérő szerkezeti kapcsolatok adódtak. Az átlagos piaci szereplőnek tekinthető „E” bank besorolása - a $3 \mathrm{M}$ esetén mindenkitől meglehetősen távol esik, a $6 \mathrm{M}$ esetén csak a „D” bankkal mutat hasonló eredményt - arra utal, hogy az intézmény-specifikus változó a klaszterezés eredményeiben is jelentősen érezteti a hatását. A szokásos 7-9 körüli vágási értéket figyelembe véve mindkét esetben két csoport adódik a többitől távol eső intézmények mellett, melyekből a „,D”-,G”„H” bank viselkedésének kapcsolata a vizsgált tenorok mindegyikében fennáll. Emellett fontos kiemelni, hogy 6-8 intézmény becsült viselkedése nem mutat kapcsolatot egyik másik intézmény becsült viselkedésével sem.

A kapcsolat szorosságát szemléltetve a 6 hónapos tenor esetén „D” - „H” bank viszonylatában 42, míg a „B” - „„” bank viszonylatában 861 kereskedési napból már 332 eltérően becsült nap adódik. Megítélésem szerint a kapott kapcsolati szerkezet annak is köszönhető, hogy egy jelenleg teoretikusan létező termékhez készítettem becslést, és így mindösszesen egy intézmény-specifikus változó került beépítésre a modellbe. Mivel az intézmények a jegyzésnél a legtöbb esetben azonos információkból indulnak ki, várható volt, hogy néhány esetben a kapott eredmények között csak minimális különbségek lesznek. 
A kapott eredmények validitását alátámasztja, hogy a becsült intézményi szintü viselkedések eltérő struktúrákat mutatnak. Amennyiben szoros összefüggést tapasztalnánk, az megkérdőjelezné az eredmények értelmezhetőségét. A gyakorlatban ugyanis egy teoretikus termékről mondanak véleményt a kereskedők, és alacsony annak a valószínűsége, hogy az összes kereskedő piacról alkotott vélekedése szinte folyamatosan egybeesik.

\subsection{Az elemzések eredményeinek összefoglalása}

A bemutatott elemzések alapján megállapítható, hogy a BUBOR-jegyzés esetén a LIBOR-hoz hasonló manipulálás gyanúja nem merül fel. Az elemzések alapján azonban a jegyzés több tulajdonsága is középpontba került, melyek a vizsgálata illetve ismerete véleményem szerint feltétlen szükséges a BUBOR-piacra vonatkozó bármely módosító javaslat megtételéhez. Összefoglalásaként pontokba gyűjtöttem a főbb megállapításokat, melyek véleményem szerint alátámasztják a BUBOR jegyzési folyamatának vizsgálata során megfogalmazódott megállapításokat is:

- Jelenleg a BUBOR-nak nincsen mögöttes piaca, ezért bármilyen elemzéshez elengedhetetlen benchmarkok/proxyk alkalmazása. Amennyiben valamely benchmarkból a BUBOR-értékek egyértelműen levezethetők lennének, akkor felvetődne a helyettesíthetőség, mivel a BUBOR-értékek semmilyen többletinformációt nem hordoznának. A statisztikai elemzések azonban alátámasztják, hogy a BUBOR-értékek egyetlen más benchmarkból sem vezethetők le, vagyis a BUBOR egyértelmű helyettesíthetősége nem lehetséges.

- A jegyzések nyesés nélküli szórása is nagyon alacsony. Nagyobb szórások turbulensebb piaci körülmények között tapasztalhatók. (P1. 2008. október, 2009. március vagy 2012. január)

- A nyesés szerepe a BUBOR-érték robosztusságnál kiemelten fontos, ugyanis a napi jegyzések tenoronkénti alsó és felső $25 \%$-ának elhagyása jelentősen csökkenti a manipuláció kockázatát.

- A piaci tényviselkedések vizsgálatánál látható, hogy vannak olyan aktív kamatjegyző intézmények, melyek jellemzően felfelé, és vannak, melyek lefelé húzzák a BUBORértéket. Egyirányú együttes torzítást nem tapasztalható, mely tény a BUBOR-értékek kooperatív befolyásolásának kérdését vetné fel. 
- Azonosíthatók időszakok, amikor megváltozik az egyes benchmarkok hatása. Ez is bizonyítja, hogy a BUBOR-értékek nem vezethetők le egyetlen más piaci benchmarkból sem, így nem helyettesíthetők.

- Az adattisztítás során felfedezett több nyilvánvalóan téves jegyzés a korábbi kontrollfolyamatok nem megfelelő szintjére utal.

- A jegyzésekben a szórás növekedését eredményező, de összehangolt viselkedést nem mutató bankok jegyzési folyamata visszavezethető arra, hogy a két legaktívabb piaci szereplő tudja legjobban lereagálni a piaci változásokat, és ezt jeleníti meg a jegyzéseiben.

A felsorolt tények indokolták/indokolják piacfejlesztő javaslatok kialakítását, melyek a bankközi piac újraélesztésére, a bankközi limitek kiterjesztésére és az önként vállalt üzletkötési kötelezettség bevezetésére irányulnak. Ez irányba a magyar pénzügyi felügyelet is tett lépéseket, hiszen 2013 során ajánlást adott ki a BUBOR-jegyzésére vonatkozóan. Az ajánlás eredményeképpen erősödött a jegyzés körüli külső és belső kontrollfolyamat, tenorokat szüntettek meg. (2014-töl a BUBOR-t már csak kilenc tenorban jegyzik a korábbi 15 helyett.)

\subsection{A BUBOR és a banki belső folyamatok kapcsolata}

A statisztikai elemzés során is rávilágítottam, hogy a BUBOR-jegyzés tenoroktól függetlenül erőteljesen konvergál a mindenkori jegybanki alapkamat szintjéhez. Ezt mind a 3, mind a 6 havi jegyzés esetén részletesen alá is támasztottam. Az elemzésekből megállapítható, hogy ennek fö oka, hogy a BUBOR mögöttes termékének a piaca kiszáradt - egyetlen aktív tenornak kizárólag az egynapos tenor tekinthető -, ennek eredményeképpen a kamatjegyző intézmények a referencia-kamat értékét egyre erősebben a jegybanki alapkamathoz kezdték benchmarkolni.

Ez a folyamat azonban számos banküzemi kérdést felvet, mivel a jegybanki alapkamat szintje a 2 hetes jegybanki betét kamatszintjének felel meg. Amennyiben egy 3 illetve 6 hónapos bankközi fedezetlen termék kamatszintje megegyezik a 2 hetes jegybanki betét kamatszintjével az alábbi közgazdasági ellentmondások merülnek fel:

- a fedezetlen bankközi piac szereplöinek a partnerkockázata megegyezik a Magyar Nemzeti Bank partnerkockázatával; 
- a 2 hetes illetve 3 (vagy 6) havi jegyzések egybeesése vízszintes hozamgörbére utal, vagyis arra, hogy ezen periódusok között egy később bekövetkező pénzáramlás nem hordoz további addicionális kockázatokat.

A valóságban ezek igazak lennének? Nehezen hihető, és a múltbeli piaci folyamatok sem támasztják alá. A partnerkockázat kérdéskörét tekintve a korábbi fejezetekben bemutattam, hogy egyes periódusokban a partnerkockázat is megjelenik a jegyzésben, de a partnerkockázat mértékének változásait nem tükrözik a BUBOR-érték szintjében bekövetkező változások. Ez az intézmények árazásában jelentős bizonytalanságot okoz. A BUBOR-jegyzésben le nem fedett partnerkockázatokat az árazás során az intézmények a kamatfelárban jelenítik meg. Azonban a megszabott kamatfelár esetén is kérdéses, hogy az intézménynek egy nem várt piaci esemény esetén is megfelelő mértékü jövedelem szintet biztosít-e a termék árazása.

Ennek szemléltetéséhez tekintsünk egy egyszerü példát. Egy intézmény fedezetlen hitelt nyújt egy másik intézménynek egy éves futamidőre, a hitel kamatfizetése negyedévente történik 3 havi BUBOR alapján változó kamatozással, a tőketörlesztés egy részletben történik a futamidő végén. A hitel kamatlába 3 havi BUBOR + 120 bázispont. A 3 havi BUBOR értéke 3,3\%, a szabályozás alapján a kamatfelár a hitel futamideje alatt nem módosítható.

Továbbá felteszem, hogy a jegybanki alapkamat szintje nem változik az elkövetkezendő egy év alatt és a múltbeli időszakokhoz hasonlóan a partnerkockázat változása csak minimális mértékben jelenjen meg a forint referencia-kamat értékében (esetünkben felteszem, hogy a tényleges változás $10 \%$-a épüljön be a BUBOR szintjébe). Az intézmény a hitel nyújtásához fedezett bankközi hitelt vesz fel, mely egy adott benchmark ráta (BR) alapján árazódik, azonban a partnerkockázatok teljes mértékben beépülnek a rátába. A forrásoldali hitel szintén egy éves futamidejü, és a futamidő végén egy összegben történik a töketörlesztés. Kamatfizetés negyedévente.

Tételezzük fel, hogy a hitel nyújtása után egy nappal a szektort egy sokkhatás éri, és a szereplők egymás partnerkockázatait magasabbnak értékelik, mely 60 bázispont növekedést indukál BR értékében. Felteszem, hogy sem a BUBOR, sem a BR értéket más tényező nem mozgatja a vizsgált periódusban. Ekkor tekintsük a példában szereplő intézmény eszköz illetve forrásoldalához kapcsolódó cash flow értékeket (a hitel összege 100 millió Ft): 
20. táblázat: Példa a BUBOR intézményi belső alkalmazása által felmerülő kérdésekre I. - folyósításkor tervezett eredmény

folyósítás negyedév I. negyedév II. negyedév III. negyedév IV.

\begin{tabular}{c|ccccc|}
\hline BUBOR (\%) + $120 \mathrm{bp}$ & $4,5 \%$ & $4,5 \%$ & $4,5 \%$ & $4,5 \%$ & $4,5 \%$ \\
BR (\%) & $3 \%$ & $3 \%$ & $3 \%$ & $3 \%$ & $3 \%$ \\
Kamatbevétel & & $1,125 \mathrm{~m} \mathrm{Ft}$ & $1,125 \mathrm{~m} \mathrm{Ft}$ & $1,125 \mathrm{~m} \mathrm{Ft}$ & $1,125 \mathrm{~m} \mathrm{Ft}$ \\
Kamatkiadás & & $-0,75 \mathrm{~m} \mathrm{Ft}$ & $-0,75 \mathrm{~m} \mathrm{Ft}$ & $-0,75 \mathrm{~m} \mathrm{Ft}$ & $-0,75 \mathrm{~m} \mathrm{Ft}$ \\
Töke (felvett) & $-100 \mathrm{~m} \mathrm{Ft}$ & & & & $100 \mathrm{~m} \mathrm{Ft}$ \\
Tőke (nyújtott) & $100 \mathrm{~m} \mathrm{Ft}$ & & & & $-100 \mathrm{~m} \mathrm{Ft}$ \\
\hline Eredmény & & $0,375 \mathrm{~m} \mathrm{Ft}$ & $0,375 \mathrm{~m} \mathrm{Ft}$ & $0,375 \mathrm{~m} \mathrm{Ft}$ & $0,375 \mathrm{~m} \mathrm{Ft}$
\end{tabular}

A 20. táblázat az intézmény hitelfolyósításhoz kapcsolódó tervezett kamateredményét tartalmazza. Linearizált kamatszámítást feltételezve az intézmény ceteris paribus 375 ezer forint kamateredményt realizál negyedévente. Azonban a külső hatások ezt ez eredményt jelentősen képesek erodálni, hiszen az előző bekezdésben megfogalmazott 60 bázispontos sokkhatás esetén a tényleges eredmény - a tervezettnél 135 ezer forinttal alacsonyabb - csak 240 ezer forint lenne, vagyis $36 \%$-kal alacsonyabb.

21. táblázat: Példa a BUBOR intézményi belső alkalmazása által felmerülő kérdésekre II. - valós eredmény folyósítás negyedév I. negyedév II. negyedév III. negyedév IV.

\begin{tabular}{c|ccccc|}
\hline BUBOR (\%) + 120 bp & $4,5 \%$ & $4,56 \%$ & $4,56 \%$ & $4,56 \%$ & $4,56 \%$ \\
BR (\%) & $3 \%$ & $3,6 \%$ & $3,6 \%$ & $3,6 \%$ & $3,6 \%$ \\
Kamatbevétel & & $1,14 \mathrm{~m} \mathrm{Ft}$ & $1,14 \mathrm{~m} \mathrm{Ft}$ & $1,14 \mathrm{~m} \mathrm{Ft}$ & $1,14 \mathrm{~m} \mathrm{Ft}$ \\
Kamatkiadás & & $-0,9 \mathrm{~m} \mathrm{Ft}$ & $-0,9 \mathrm{~m} \mathrm{Ft}$ & $-0,9 \mathrm{~m} \mathrm{Ft}$ & $-0,9 \mathrm{~m} \mathrm{Ft}$ \\
Tőke (felvett) & $-100 \mathrm{~m} \mathrm{Ft}$ & & & & $100 \mathrm{~m} \mathrm{Ft}$ \\
Tőke (nyújtott) & $100 \mathrm{~m} \mathrm{Ft}$ & & & & $-100 \mathrm{~m} \mathrm{Ft}$ \\
\hline Eredmény & & $0,24 \mathrm{~m} \mathrm{Ft}$ & $0,24 \mathrm{~m} \mathrm{Ft}$ & $0,24 \mathrm{~m} \mathrm{Ft}$ & $0,24 \mathrm{~m} \mathrm{Ft}$
\end{tabular}

A példa tisztán szemlélteti az intézmények kamatkockázatát, amivel akkor szembesülnek, ha az eszköz- illetve a forrásoldali tételek fedezése az átárazódás bázisául szolgáló kamatlábakat figyelembe véve nem tökéletes (pl. 3 havi BUBOR alapján árazódó eszközzel szemben 3 havi BUBOR alapján árazódó forrás áll, és a tételek kamatozása csak rögzített felárban különbözik).

Magyarországon a hitelintézetek a lakossági betétek többségét a jegybanki alapkamat alapján árazzák - a betéti kamatok együttmozognak az alapkamat mértékével. A korábbi fejezetekben bemutattam, hogy a BUBOR szinte a jegybanki alapkamathoz konvergál, így a lakossági betétállományokhoz és a velük szembenálló BUBOR alapján árazódó hitelállományokhoz 
köthető kamatkockázat mértéke mérsékelt, hiszen a mind az eszközoldal, mind a forrásoldal a jegybanki alapkamat változását követi le.

Azonban nem lehetséges az összes hitelt lakossági betétből finanszírozni, ezért az intézmények bankközi forrásokat is igénybe vesznek a hitelnyújtási tevékenység biztosításához. A magyar piacon több leánybank is tevékenykedik, melynek anyavállalata külföldi devizában bocsát közép-, hosszútávú forrásokat a leánybank részére. Az euró források jellemzően EURIBOR-hoz, a dollár vagy svájci frank források LIBOR-hoz kötöttek. Feltételezve, hogy az intézmény forint alapú hiteleket bocsát ki, az anyabanktól kapott devizát az intézmények konvertálják, és BUBOR alapú hiteleket nyújtanak az ügyfelek részére.

Egy bank lakossági üzletága nem folytat aktív tevékenységet a bankközi piacon, hanem az üzleti tevékenységéhez szükséges forrásigényét eljuttatja a treasury illetékes területéhez (ezt a szerepet általában a treasury ALM deskje tölti be), amely a bankközi piacról forrást biztosít. A betöltött szerepeket szemlélteti a következő ábra.

31. ábra: Hitelfolyósítás belső elszámolásának sematikus szemléltetése

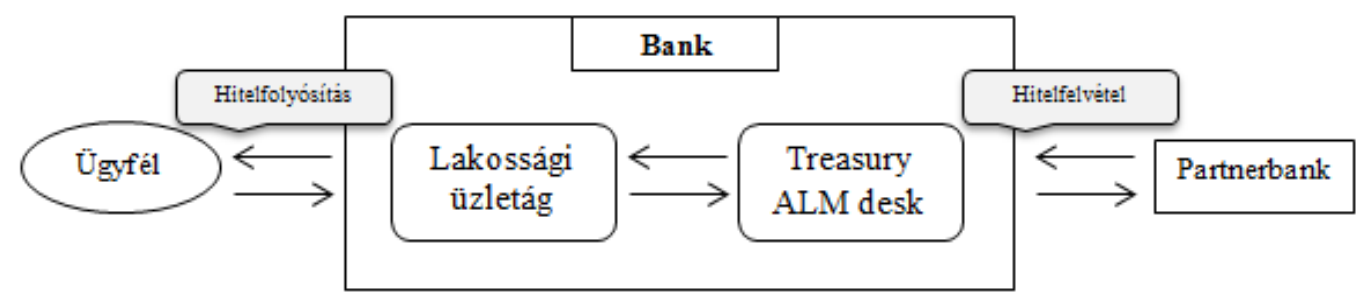

A funkciók szétválasztása profitabilitási és kockázatkezelési szempontok alapján egyaránt indokolt. Kockázatkezelésileg kiemelten fontos, hogy a szétválasztás által nem mossák össze a lakossági piac és a bankközi piac kockázatait, így az egyes tevékenységek kockázata önállóan is mérhető, és a kockázatok közötti diverzifikációs hatások túlértékelése is kiküszöbölhető. Emellett kiemelten fontos, hogy így elkerülhető az az érdekkülönbség, hogy a lakossági üzletág túlzott kockázatvállalásra törekedjen nagyobb volumenű folyósításokkal. A nagyobb volumenü folyósítás a jutalékokon keresztül az üzletkötők javadalmazásába is beépül, akik ezt nagyobbra értékelhetik, mint a nagyobb volumenü forráshoz kapcsolódó magasabb átlagos költséget. Ezáltal az intézmény profitabilitása is csökkenhetne, illetve jelentős méretű portfólió felépülése esetén koncentrációs kockázatok is felmerülhetnek. A funkciók egymástól független szervezeti egységekbe való delegálásával az intézmény „házon belül” oldja meg a felmerülő problémákat. 
Ugyanakkor az optimális tevékenység meghatározása egy új kérdést nyit meg. Mi alapján kerüljön meghatározásra a lakossági üzletág és a treasury közti belső elszámoló ár, mely alapja az egyes tevékenységének a kiértékelésének? Ezen elszámoló áraknak az üzleti tevékenységre is kihatásuk lehet, hiszen egyáltalán nem mindegy, hogy egy adott tevékenységhez mekkora mértékű profitabilitás társul.

Az olvasóban most felmerülhet, a magyar problémakör mennyivel másabb egy olyan német bank eseténél, ahol a forrás LIBOR, az eszköz pedig az EURIBOR alapján árazódik át? Miért nehezebb ez a kérdéskör? A válasz a korábban már többször jelzett tényben keresendő, vagyis abban, hogy a BUBOR piac fokozatosan szükült, és a jegyzések minden futamidő esetén egyre erőteljesebben a jegybanki alapkamathoz konvergáltak. A jegybanki alapkamat a 2 hetes jegybanki betét kamata, vagyis egy 6 hónapos BUBOR szint változékonysága szinte teljesen megegyezik egy 2 hetes jegybanki betét kamatszintjének a változékonyságával. Ez azt is jelenti, hogy egy váratlan piaci sokk esetén a BUBOR a többi benchmarkhoz képest eltérő mértékben alkalmazkodik az új körülményekhez, vagyis a BUBOR esetén a korlátozott alkalmazkodási képességből fakadó eltérés sokkal nagyobb lehet, mint a német bank felhozott példájában.

Felmerül a kérdés, egy ilyen esetben, hogyan határozzuk meg a két banki szakterület közötti elszámoló árat? Erre nincs általánosan alkalmazható jó válasz, azonban az alábbiakat feltétlen érdemes figyelembe venni:

- A forrás árazását teljes mértékben továbbhárítani a lakossági üzletágra nem érdemes, mivel ekkor a treasury ALM deskje nem lenne érdekelt a lehető legjobb piaci feltételek elérésében, hiszen a saját teljesítménye nem függne az általa biztosított forrás árától, és ez a bank számára sem biztos, hogy a legolcsóbb forrást eredményezné.

- A hiteltermékek árazását teljes mértékben a treasuryre hárítani szintén nem jó megoldás, hiszen ekkor az értékesítő üzletág eredményét - eltekintve az ügyfelek hitelkockázatától - kizárólag az értékesítés volumene határozza meg, vagyis nem ösztönöz az adott termék esetén optimális portfólió kialakításra.

A fenti két pontból látható, hogy egy köztes megoldás lehet üdvözítő, melynek meghatározása azonban nem egyértelmü. A megoldásban a tevékenység teljes banki eredményre gyakorolt hatását szét kell osztani, a szétosztás mérték viszont sok eseti sajátosságtól függhet, melyek idővel és terméktípusonként változhatnak. Egy belső üzleti terület jövedelmezőségi 
mértékének a megítélése kulcskérdés, hiszen ennek függvényében hozott döntések a terület további müködését alapjaiban befolyásolhatják. A szétosztással minden érintett belső területet optimális működését lehet ösztönözni.

A feladatban a nehézséget az okozza, hogy nem kizárólag visszamérésről van szó, hiszen ekkor a szétosztás mértékét is könnyebb meghatározni. A belső elszámoló ár meghatározását előre rögzíteni szükséges, hiszen az egyes területek csak egy már előre ismert elszámoló ár mechanizmus alapján képesek transzparensen megtervezni a müködésüket. Egy ismeretlen mechanizmus alapján nem lehetséges megalapozottan a megfelelő termékpaletta kialakítása sem. A szétosztást eredményező mechanizmusnak a felállítása azonban egy folytonos konzultáció eredménye - általában csak a főbb elemei rögzítettek -, mivel az egyes területek képviselő eltérő mértékben vélekednek a szétosztás helyes mértékéről. Ezek a vélemények képlettel pedig nehezen megragadhatók.

A belső elszámoló ár meghatározásán túl a BUBOR szintjének a jegybanki alapkamathoz való konvergálása egy másik problémakört is felvet. A hozamgörbe becsléseknél bevett gyakorlat a pénzintézeteknél, hogy az adott deviza referencia-kamatából indulnak ki. A forint esetében helyes ez a feltételezés? Könnyen belátható, hogy további kérdéseket vet fel, amennyiben egy intézmény a hozamgörbe becslésnél a BUBOR-ra alapoz a hónapon túli, de egy évnél rövidebb tenorok esetén. Mivel a tenorok egységesen a jegybanki alapkamathoz tartanak, és az eltérés közöttük minimális a BUBOR alapján a hozamgörbe egy hónaptól induló szakasza szinte vízszintesnek tekinthető (lásd 32. ábra), és jelentősebb változások csak az alapkamat változtatások környékén tapasztalhatók. Helyes ez az állítás?

32. ábra: BUBOR-jegyzésekből készített hozamgörbe 2011. június 20. - 2011. június 24.

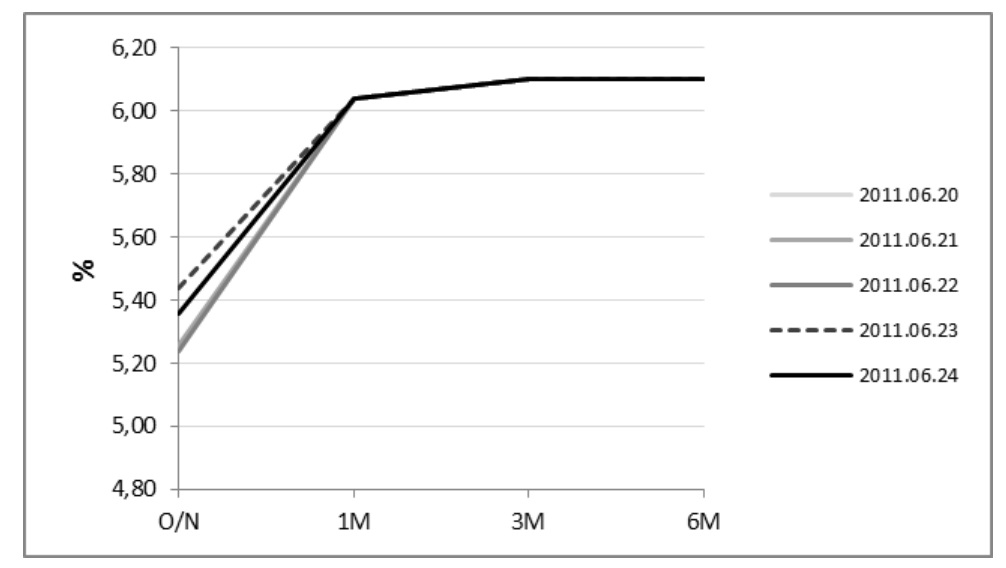

forrás: MNB, saját szerkesztés 
Ennek eredményeképpen egy fél év múlva esedékes pénzáramlás esetén a tartási idő hosszabbodásán túl semmilyen más többlet kockázatot, vagy piaci várakozást nem tükröznek a hozamgörbe értékei, mint egy 2 hét múlva esedékes pénzáramlás esetén. Mennyire tekinthető egy ilyen hozamgörbe alapján készített nettó jelenérték becslés valósnak? A kockázatkezelés által bemutatott számok a valóságot tükrözik? Az intézmény megfelelő fedezeti stratégiát alkalmaz? Ezek mind olyan kérdések, melyeket a fenti problémából adódnak, és a magyarországi bankok esetében kiemelten fontosak. A kockázatkezelési területeknek ezért erre fokozatosan ügyelniük kell, és mérlegelni, hogy a BUBOR alkalmazása megfelel-e az aktuális elemzési céloknak.

A korábbi fejezetekből látható, a BUBOR fontos szerepet tölt be az intézmények mindennapi életében, és kiemelten fontos számukra, hogy fennmaradjon, hiszen a forint alapú termékek jelentős része BUBOR alapján árazódik. Ugyanakkor a lakosság érdeke is a budapesti jegyzés fennmaradása, hiszen a magyar intézmények precízebben képesek meghatározni a BUBORértékét, mintha Londonban külföldi bankok által történne a forint referencia kamatának a jegyzése. A magyarországi lakossági banki tevékenységet folytató intézmények esetén emellett sokkal nagyobbak a jegyzéssel kapcsolatos reputációs kockázatok, amelyek a jegyzésnél fokozottabb odafigyelésre ösztönzik őket. A fejezetben is említett problémák elsődleges oka, hogy a BUBOR-piac egyre jobban kiszáradt, és egy szinte teoretikus jegyzés alakult ki. A piac aktivitásának növelésével a fentebb említett problémák megszüntethetők. Az aktivitás növelése az egész világon komoly kihívás elé állítja az illetékes szakembereket, azonban a végleges megoldás továbbra is keresés alatt áll.

\subsection{Lehetséges további kutatási irányok}

A tanulmányomban részletesen bemutattam, hogy leíró statisztikai módszerekkel is fontos információkra következtethetünk a budapesti forint hitelkamatláb jegyzési értékeiből. Az elemzésből kirajzolódnak mind a mögöttes termék piacának, mind a jegyzést végző intézmények viselkedési tulajdonságai.

A kétlépcsős klaszterelemzés alapján belátható, hogy képlettel leírható viselkedési sémák nem azonosíthatók, ugyanakkor a validációs lépések alátámasztják a modell alkalmazhatóságát. Azonban még ezen tanulmány keretei sem elégségesek minden lehetséges elemzési módszertan szemléltetéséhez. A további lehetőségek közül feltétlen megemlítendő a kointegráció tesztelése. 
A dolgozatomban az idősorok együttmozgását az eltérések leíró statisztikájának, illetve a jegyzések távolságának vizsgálatán keresztül ragadtam meg. További érdekes eredményekre vezethet mind az egyes aktív kamatjegyző intézmények jegyzési idősorának, mind a különböző BUBOR-tenorok illetve a BUBOR és az alternatív benchmark-értékek együttmozgásának vizsgálata. Ezekhez alkalmazhatjuk Engle és Granger (Engle-Granger [1987]), Johansen (Johansen [1991]) vagy Phillips és Ouliaris (Phillips-Ouliaris [1990]) által ajánlott módszertanokat is. Elemzésemben megmutattam, hogy több esetben (például a BUBOR és a jegybanki alapkamat, különböző BUBOR tenorok között) az idősorok együttmozgása nagyon szoros. A kointegrációs elemzéshez célszerü lehet az idősorokat előre meghatározott pontokon elvágni és a kointegrációs kapcsolat változását is vizsgálni. Az elemzésem során vágási pontnak elsődlegesen a 2008-as globális válságot tekintettem, illetve egyes elemzésekhez a rendelkezésemre álló idősorok visszamenőleges hossza is korlátokat szabott. Kizárólag ezen vágási pontok meghatározásának is egy hosszabb tanulmányt lehetne szentelni. Hiszen egyáltalán nem nyilvánvaló, hogy külföldi vagy belföldi bankpiaci, vagy államháztartási, esetleg más gazdasági eseményeket, indikátorokat keresünk-e. Ezek függvényében az eredményeink is nagyon eltérőek lehetnek.

A 3. fejezetben bemutatott játékelméleti modell továbbfejlesztése a hitelintézeti döntési mechanizmusainak alaposabb vizsgálatát teszi lehetővé. Egyedi kifizető függvények hozzárendelésével az optimális/manipulatív jegyzések meghatározása, illetve annak vizsgálat, hogy különböző típusú kamatjegyzőknek (egyeseknél kamatnövelésre, másoknál kamatcsökkentésre van ösztönzés) az ösztönző hatások által befolyásolt jegyzéseinek hatásai mekkora mértékben oltják ki egymást a nyesett átlagolás során. Vagyis annak vizsgálata, hogy egyensúlyban a manipuláció eredményez-e egyáltalán profitot.

Egy másik érdekes megközelítés lehet a referencia-kamat szabályzatának a fóbb pontjainak nemkooperatív illetve kooperatív játékelméleti vizsgálata. Mely feltételek biztosítják az igazmondást? Vannak-e olyan feltételezések, melyek a viselkedésük megváltoztatására ösztönözhetik az intézményeket? Egy új szabályzati feltétel (például üzletkötési kötelezettség) hordoz-e ösztönzőt az aktív kamatjegyző intézmények számára. 


\section{6. Összegzés}

A londoni bankközi referencia-kamatlábbal kapcsolatos botrány utóhatásának egyik legnagyobb tanulsága az, hogy rávilágít, mennyire is szorosan összefüggnek a nemzetközi pénzpiacok. A LIBOR manipulálásának híre az egész világra kiterjedő folyamatokat indított el - azon túl, hogy a londoni aktív kamatjegyző bankok tevékenységét nem kizárólag az angol, hanem az amerikai felügyelet is vizsgálta. Európa szerte - köztük Magyarországon is vizsgálatok indultak a helyi referencia-kamatlábak vizsgálatára, az esetleges manipulációk felderítésére illetve a piacok megnyugtatására. Ez a kiemelt figyelem azonban a korábbi tudományos kutatások egy lefedetlen szegmensére is rávilágított.

A dolgozatomban több tényre is rámutattam, amelyek a korábbi tanulmányokban alig vagy egyáltalán nem is kaptak hangsúlyt. A budapesti bankközi forint hitelkamatláb esetén kiemelten fontos, hogy bár a londoni bankközi referencia-kamatláb mintájára hozták létre, mégis már maguk a definíciók is jelentős különbséget hordoznak. Azok az elsődleges ösztönzök (a bankközi ügyletekböl származó eredmény, az aktív kamatjegyzö bank hitelképességének jelzése), melyek a LIBOR manipulálását eredményezték, a budapesti jegyzés esetében nem vagy csak minimális mértékben voltak jelen. A részletesebb elemzésem rávilágít, hogy a fenti ösztönzők hiánya mellett is azonosíthatók gyengeségek a jegyzési folyamat során. A korábban a referencia-ráták vizsgálatára végzett elemzések (pl.: De JongDriessen-Pelsser [2001] vagy Jagannathan-Kaplin-Sun [2003]) nem elégségesek a jegyzések transzparenciájának biztosítására, mivel elsődlegesen a referencia-értékek felhasználására fókuszáltak.

$\mathrm{Az}$ 5. fejezetben rámutattam, hogy egyszerü leíró statisztikai elemzésekkel is kinyerhetök fontos információk a referencia-kamatláb jegyzése mögötti feltételezésekröl. A referenciakamat és jegybanki alapkamat eltérésének összevetéséből kiolvasható, hogy az aktív kamatjegyző intézmények által kialakított BUBOR-értékek 2012-ig - a turbulens piaci időszakok kivételével - egyre jobban közelítettek a jegybanki alapkamathoz, vagyis a mögöttes termék piacának visszaszorulása mellett az intézmények a jegybanki referencia-ráta felé fordultak el. Az intézményi jegyzések szórásának idősora alátámasztotta, hogy ez az elmozdulás egységes volt, hiszen a szórások értékei nem emelkedtek számottevően. Az aktív kamatjegyző intézmények jegyzéseinek differencia idősorát vizsgálva belátható, hogy egy dinamikusan müködő piac tulajdonságai 2012-ig fokozatosan tüntek el a jegyzésekböl. 
Figyelembe véve azt az elsődleges tényt, hogy a válság alatt a BUBOR mögöttes termékének (fedezetlen bankközi hitel) piaca szinte kiürült, egyes esetekben elméleti becslésként lehetett rá tekinteni. Emiatt a jegyzések statisztikai vizsgálata több esetben módszertani akadályokba ütközik, mivel a modellfeltételek sok esetben nem teljesülnek. A hónapon túli fedezetlen bankközi hitelpiac visszaszorulásával az intézményi jegyzések az idő előrehaladtával 2012-ig szoros együttmozgást kezdtek követni a jegybanki alapkamat pályájával. Az aktív kamatjegyzők 2008 októberétől kezdve a kereskedési napok több mint 75\%-án nem módosítottak az előző napi jegyzésükhöz képest, így a differencia idősorok vizsgálata is korlátozott. Mindazonáltal ez a tény is mutatja, hogy a BUBOR egy nagyon erős AR(1) folyamattá vált (lásd többek között Erhart-Ligeti-Molnár [2013]).

Az aktív kamatjegyző intézmények egyedi jegyzéseit vizsgálva megállapítottam, hogy nem volt olyan intézmény, mely tartósan alul- vagy felüljegyezte volna a budapesti bankközi referencia-kamatlábat. Emellett azt is megállapítottam, hogy az intézmények a BUBOR-piac egyre erőteljesebb kiszáradásának következtében egyre közelebb húzták az irányadó értéket a jegybanki alapkamathoz. Ez azon fogyasztók szempontjából kiemelten fontos, akiknek a hitelterméke a BUBOR alapján árazódik, hiszen az aktív kamatjegyzők nem egy kockázatosabb termék felé fordultak, ami jelentős költségnövekedést eredményezett volna a fogyasztók számára. Ugyanis a jegybanki alapkamat megegyezik a kéthetes jegybanki betét kamatával, így a jegybank és átvitt értelemben a magyar állam kockázatát jeleníti meg. Ebből következően az intézmények további additív kockázatokból származó felárat csak minimálisan építettek be a budapesti bankközi forint hitelkamatláb szintjébe.

A jogszabályi hivatkozások is egyértelműen mutatják, hogy a BUBOR-ra valós igény van. Különösen abból a szempontból, hogy a budapesti referencia-rátát magyar szakemberek alakítsák ki és ne külföldről befolyásolják a magyar bankközi piacot. Egy esetleges londoni jegyzés esetén a nagy befektetési bankházak számára a tanulmányomban ismertetett manipulálási ösztönzők sokkal erősebbek. Számukra a forint piac nem tartozik az alaptevékenységükhöz, csak a kiterjesztett müködésük egy szerepe. Az itt fellépő esetleges piaci zavarok, illetve reputációs kockázatok sokkal kevésbé érintik őket, mint a Magyarországon telephellyel rendelkező és aktív kereskedelmi tevékenységet is folytató intézményeket. A BUBOR minél transzparensebb alkalmazásának érdekében a jegyzési folyamatot rendszeresen monitorozni és elemezni szükséges. A dolgozatomban feltárt gyengeségek egybevágtak az EURIBOR jegyzési folyamatában is tapasztalt gyengeségekkel. Az elemzéseim során alkalmazott módszertanok jó kiindulási alapot jelentenek a jövőbeli 
elemzésekhez, melyek segítségével a referencia-értékek jegyzési tulajdonságai feltárhatók és további információkkal támogathatják a kutatókat a megfelelő mélyebb elemzési módszerek kiválasztásában.

A magyarországi elemzések és a felügyeleti hatóság ajánlásának figyelembe vételével a Magyar Forex Társaság elindította a budapesti bankközi forint hitelkamatláb jegyzésének reformját. Ennek eredményeképpen megújult a BUBOR-szabályzat (MFT [2014]), mely az előző szabályzathoz képest (MFT [2013]) sokkal részletesebben rögzíti a jegyzés folyamatát. A BUBOR-nak továbbra is jelentős transzparenciát biztosít az, hogy a Magyar Nemzeti Bank továbbra is részt vesz a jegyzési folyamatban, és így nem egy független szervezet, hanem a szabályozó-felügyeleti hatóság összesíti a jegyzéseket.

A BUBOR jogosultságát az elözőek mellett tovább erősíti, hogy a LIBOR körüli botrány ellenére - bár az új európai tőkedirektívához (Európai Parlament és Tanács [2013]) kapcsolódó hazai jogszabályváltozások lehetőséget adtak volna rá - a BUBOR az újonnan kiadott magyarországi jogszabályokban is megtartotta a régi szerepét. Ezt a szerepet a piaci szereplők és az MNB kellően részletesen szabályozott és rendszeresen ellenőrzött jegyzési folyamattal tovább stabilizálhatja, így meg tudja akadályozni alternatív benchmarkok keresését és hosszú életet tud biztosítani a BUBOR számára. 


\section{Irodalomjegyzék}

- Ábel I. - Kóbor Á. [2008]: Kamatkülönbözet, spekulációs profit és árfolyamváltozékonyság, Közgazdasági Szemle, 2008/11, 941-961.

- Abrantes-Metz, R. M. - Kraten, M. - Metz, A. D. - Seow, G. [2008]: LIBOR Manipulation?, Social Science Research Network, 2008. http://dx.doi.org/10.2139/ssrn.1201389

- Akerlof, G. A. [1970]. "The Market for 'Lemons': Quality Uncertainty and the Market Mechanism", Quarterly Journal of Economics, 1970, 84 (3) 488-500. http://dx.doi.org/10.2307/1879431

- Armstrong, R. [2012]: Ex-RBS trader says Brevan Howard sought Libor rate change, Reuters, http://uk.reuters.com/article/2012/03/30/uk-brevanhoward-liboridUKBRE82T0J920120330 [letöltés: 2014. szeptember 10.]

- Bayer P. [2012]: Véleményrangsorok alkalmazása pénzügyi szituációkban, Szigma, 2012, 43: (3-4) 109-123.

- BBC [2012a]: Barclays boss Bob Diamond resigns amid Libor scandal, BBC, 2012. július 3. http://www.bbc.com/news/business-18685040 [letöltés: 2014. szeptember 10.]

- BBC [2012b]: RBS has sacked four traders over the Libor-fixing scandal, BBC, 2012. július 1. http://www.bbc.com/news/business-18665508 [letöltés: 2014. szeptember 10.]

- BBC [2014]: Lloyds dismisses eight staff over Libor, BBC, 2014. szeptember 29. http://www.bbc.com/news/business-29410742 [letöltés: 2014. október 1.]

- Berlinger E. - Juhász P. - Lovas A. [2015]: Az állami támogatás hatása a projektfinanszírozásra erkölcsi kockázat és pozitív externáliák mellett: szerződéselméleti megközelítés, Közgazdasági Szemle 62: (2) 139-171.

- British Bankers Association (BBA) [2014]: bbalibor website, BBA Enterprises Ltd and BBA LIBOR Ltd., http://www.bbalibor.com/

- Commodity Futures Trading Commission (CFTC) [2012a]: CFTC Orders Barclays to pay \$200 Million Penalty for Attempted Manipulation of and False Reporting concerning LIBOR and Euribor Benchmark Interest Rates, CFTC, 2012. június 27. http://www.cftc.gov/PressRoom/PressReleases/pr6289-12 [letöltés: 2014. március 10.]

- Commodity Futures Trading Commission (CFTC) [2012b]: CFTC Orders UBS to Pay $\$ 700$ Million Penalty to Settle Charges of Manipulation, Attempted Manipulation and False Reporting of LIBOR and Other Benchmark Interest Rates, CFTC, 2012. december 19. http://www.cftc.gov/PressRoom/PressReleases/pr6472-12 [letöltés: 2014. szeptember 10.]

- Commodity Futures Trading Commission (CFTC) [2012c]: Examples of Misconduct From Written Communications, CFTC, 2012. december 19. http://www.cftc.gov/ucm/groups/public/@newsroom/documents/file/misconductwritte ncommunication.pdf [letöltés: 2014. szeptember 10.]

- Commodity Futures Trading Commission (CFTC) [2013]: CFTC Charges ICAP Europe Limited, a Subsidiary of ICAP plc, with Manipulation and Attempted 
Manipulation of Yen Libor, CFTC, 2013. szeptember 25. http://www.cftc.gov/PressRoom/PressReleases/pr6708-13 [letöltés: 2014. szeptember 10.]

- Commodity Futures Trading Commission (CFTC) [2014]: CFTC Charges Lloyds Banking Group and Lloyds Bank with Manipulation, Attempted Manipulation, and False Reporting of LIBOR, CFTC, 2014. július 28. http://www.cftc.gov/PressRoom/PressReleases/pr6966-14 [letöltés: 2014. szeptember 20.]

- Csávás Cs. - Varga L. - Balogh Cs. [2007]: A forint kamatswappiac jellemzői és a swapszpredek mozgatórugói, MNB Tanulmányok 64.

- Csóka P. - Havran D. - Szücs N. [2013]: Corporate financing under moral hazard and the default risk of buyers, Central European Journal of Operational Research, 2013, 22. 1-16.

- De Jong, F. - Driessen, J. - Pelsser, A. [2001]: Libor Market Models versus Swap Market Models for Pricing Interest Rate Derivatives: An Empirical Analysis, $\begin{array}{llll}\text { European Finance 2001, Review, 201-237. } & \text { 20 }\end{array}$ http://dx.doi.org/10.1023/A:1013816921237

- Diehl, C. [2013]: The LIBOR mechanism and Related Games, Bielefeld Universitat, 2013, Center of Mathematical Economics Working Papers Nr. 482

- Dunkley, J. - Wilson, H. [2011]: Barclays 'must' come clean on Libor probe, The Telegraph, 2011. március 18. http://www.telegraph.co.uk/finance/newsbysector/banksandfinance/8389106/Barclays-must-come-clean-on-Libor-probe.html [letöltés: 2014. március 10.]

- Engle, R. F. - Granger, C. W. J. [1987]. Co-integration and error correction: Representation, estimation and testing, Econometrica 55 (2): 251-276. http://dx.doi.org/10.2307/1913236

- Enrich, D. - Mollenkamp, C. - Eaglesham, J. [2011]: U.S. Libor Probe Includes BofA, Citi, UBS, Wall Street Journal, http://online.wsj.com/news/articles/ [letöltés: 2014. március 10.]

- Erhart Sz. - Ligeti I. - Molnár Z. [2013]: A LIBOR-átvilágítás okai és hatásai a nemzetközi bankközi referenciakamat-jegyzésekre, MNB Szemle, 2013. január

- European Banking Authority - European Securities and Markets Authority (EBAESMA) [2012]: ESMA and the EBA take action to strengthen Euribor and benchmark rate-setting processes, ESMA http://www.esma.europa.eu/news/ESMA-and-EBAtake-action-strengthen-Euribor-and-benchmark-rate-setting-processes [letöltés: 2014. március 8.]

- Európai Bizottság [2013]: Antitrust: Commission fines banks $€ 1.71$ billion for participating in cartels in the interest rate derivatives industry, Európai Bizottság, 2013. december 4. http://europa.eu/rapid/press-release_IP-13-1208_en.htm [letöltés: 2014. szeptember 8.]

- Európai Parlament és Tanács [2013]: 2013/36/EU irányelv a hitelintézetek tevékenységéhez való hozzáférésről és a hitelintézetek és befektetési vállalkozások prudenciális felügyeletéröl, a 2002/87/EK irányelv módosításáról, a 2006/48/EK és a 2006/49/EK irányelv hatályon kívül helyezéséről, EU, 2013. június 27. 
- Financial Conduct Authority (FCA) [2014]: Lloyds Banking Group fined $£ 105 \mathrm{~m}$ for serious LIBOR and other benchmark failings, FCA, 2014. július 28. http://www.fca.org.uk/news/lloyds-banking-group-fined-105m-libor-benchmarkfailings [letöltés: 2014. szeptember 20.]

- Financial Services Authority (FSA) [2012a]: Barclays fined $£ 59.5$ million for significant failings in relation to LIBOR and EURIBOR http://www.fsa.gov.uk/library/communication/pr/2012/070.shtml [letöltés: 2014. március 8.]

- Financial Services Authority (FSA) [2012b]: UBS fined $£ 160$ million for significant failings in relation to LIBOR and EURIBOR, FSA, 2012. december 19. http://www.fsa.gov.uk/library/communication/pr/2012/116.shtml [letöltés: 2014. szeptember 8.]

- Financial Services Authority (FSA) [2012c]: Final Notice, FSA http://www.fsa.gov.uk/static/pubs/final/barclays-jun12.pdf [letöltés: 2014. március 8.]

- Financial Services Authority (FSA) [2012d]: The Wheatley Review of LIBOR, FSA, http://cdn.hm-treasury.gov.uk/wheatley_review_libor_finalreport_280912.pdf

- Financial Services Authority (FSA) [2014]: RBS fined $£ 87.5$ million for significant failings in relation to LIBOR, FSA, 2013. február 6. http://www.fsa.gov.uk/library/communication/pr/2013/011.shtml] [letöltés: 2014. szeptember 10.]

- Financial Services Authority (FSA) [2014]: Principles for Businesses, FSA http://www.fca.org.uk/static/documents/handbook-releases/high-levelstandards 136.pdf [letöltés: 2014. június 10.]

- FINMA [2012]: LIBOR: FINMA concludes proceedings against UBS and orders disgorgement of profits, FINMA, 2012. december 19. http://www.finma.ch/e/aktuell/Pages/mm-ubs-libor-20121219.aspx [letöltés: 2014. szeptember 10.]

- Fliszár V. [2013]: A BUBOR-hoz köthető állományok és a BUBOR jegyzések részletes statisztikai elemzése, PSZÁF, 2013. február 13.

- Fliszár V. [2015]: A BUBOR-piac kiszáradásának jelei, avagy mi olvasható ki a 2006 és 2012 közötti BUBOR-jegyzésekből, Statisztikai Szemle, 2015/03, 243-259.

- Fliszár V. [2016]: Csökkenthető a referencia-kamatok manipulálásának valószínüsége? - lehetséges irányok egy egyszerüsített modell alapján a Barclays adatainak felhasználásával, Közgazdasági Szemle, befogadott - várható megjelenés 2016 első negyedév

- Forgó F. - Pintér M. - Simonovits A. - Solymosi T. [2005]: Játékelmélet, BCE, elektronikus jegyzet, 2005

- Franke, J. - Haerdle, E. K. - Hafner, C. M. [2011]: Statistics of Financial Markets, Springer, 3rd Edition

- Fraser, I. [2013]: Stephen Hester: The great escape artist, 2013. február 10. http://www.ianfraser.org/the-great-escape-artist/ [letöltés: 2014. szeptember 10.] 
- Global Financial Market Association (GFMA) [2012]: Principles for financial benchmarks, GFMA http://www.gfma.org/correspondence/item.aspx?id=350 [letöltés: 2014. június 10.]

- Gordon, A. D. [1999]: Classification, 2nd ed. Boca Raton: Chapman \& Hall/CRC

- Haaker, A. [2013]: To manipulate or not to manipulate - A short comment on the game of interest rate manipulation, International Journal of Economics, Finance and Management Sciences, 2013; 1(1) : 21-24

- Hartigan, J. A. [1975]: Clustering algorithms. New York, John Wiley and Sons

- Horváth Cs. - Krekó J. - Naszódi A. [2004]: Kamatátgyürüzés Magyarországon, MNB füzetek 2004/8.

- House of Commons [2008]: Examination of Witnesses (Questions 20-39), UK Parliament, http://www.publications.parliament.uk/pa/cm200708/cmselect/cmtreasy/1210/811250 3.htm [letöltés: 2014. július 10.]

- Huang, Z. [1998] Extensions to the k-means algorithm to clustering large data sets with categorical values. Data Mining and Knowledge Discovery, 2, 283-304. http://dx.doi.org/10.1023/A:1009769707641

- Hull, J. C. [1999]: Opciók, határidős ügyletek és egyéb származtatott termékek, Panem-Prentice Hall

- International Organization of Securities Commissions (IOSCO) [2013]: Consultation Report on Financial Benchmarks, IOSCO, http://www.iosco.org/library/pubdocs/pdf/IOSCOPD399.pdf [letöltés: 2014. június 10.]

- Jagannathan, R. - Kaplin, A. - Sun, S. [2003]: An evaluation of multi-factor CIR models using LIBOR, swap rates, and cap and swaption prices, Journal of Econometrics, 2003, Volume 116, 113-146.

- Jamshidian, F. [1997]: Libor and swap market models and measures, Finance and Stochastics 1, 293-330. http://dx.doi.org/10.1007/s007800050026

- Johansen, S. [1991]: Estimation and Hypothesis Testing of Cointegration Vectors in Gaussian Vector Autoregressive Models, Econometrica 59 (6): 1551-1580. http://dx.doi.org/10.2307/2938278

- Kovács E. [2011]: Pénzügyi adatok statisztikai elemzése, Tanszék kft

- Mackenzie, M. - Nasiripour, S. - Jenkins, P. [2012]: Barclays employee alerted NY Fed over Libor in 2008, Financial Times, 2012. július 13. http://www.ft.com/cms/s/0/d3f17a66-ccdb-11e1-9960-00144feabdc0.html\#axzz38IxtkQFC [letöltés: 2014. július 10.]

- Magyar Forex Társaság (MFT) [2013]: BUBOR szabályzat, 2013. január 1. [letöltés: 2013. szeptember 2-án]

- Magyar Forex Társaság (MFT) [2014]: BUBOR szabályzat, 2014. február 1. http://www.acihungary.hu/doc/bubor_szabalyzat.pdf [letöltés: 2014. március 10.]

- Magyar Forex Társaság (MFT) [2014a]: BUBOR szabályzat, 2014. augusztus 1. http://www.acihungary.hu/doc/bubor_szabalyzat.pdf [letöltés: 2014. október 10.] 
- Miltersen, K. - Sandmann, K. - Sondermann, D. [1997]: Closed form solutions for term structure derivatives with log-normal interest rates, The Journal of Finance 52, 409-430. http://dx.doi.org/10.1111/j.1540-6261.1997.tb03823.x

- Mollenkamp, C. [2008]: Bankers Cast Doubt On Key Rate Amid Crisis, Wall Street Journal, 2008.04.16., http://online.wsj.com/news/articles/SB120831164167818299 [letöltés: 2013. szeptember 15.]

- Mollenkamp, C. [2012]: Exclusive: U.S. conducting criminal Libor probe, Reuters, 2012. február 28. http://www.reuters.com/article/2012/02/28/us-libor-probeidUSTRE81R1ZG20120228 [letöltés: 2013. szeptember 15.]

- Mollenkamp, C. - Enrich, D. [2011]: Banks Probed in Libor Manipulation Case, Wall Street Journal, 2011.03.16., http://online.wsj.com/news/articles/SB10001424052748704662604576202400722598 060 [letöltés: 2013. szeptember 15.]

- Mooi, E. - Sarstedt, M. [2011]: A Concise Guide to Market Research, The Process, Data, and Methods Using IBM SPSS Statistics, Springer

- Pénzügyi Szervezetek Állami Felügyelet (PSZÁF) [2013]: Felügyeleti javaslatok a budapesti bankközi kamatláb szabályozására és ellenőrzésére, Sajtóközlemény, PSZÁF, http://felugyelet.mnb.hu/hirek_ujdonsagok/13_02_13-BUBOR.html [letöltés: 2014. június 10.]

- Phillips, P. C. B. - Ouliaris, S. [1990]: Asymptotic Properties of Residual Based Tests for Cointegration, Econometrica, Vol. 58, pp. 165-193 http://dx.doi.org/ $10.2307 / 2938339$

- Pintér K. - Pulai Gy. [2009]: Kamatvárakozások számszerüsítése piaci hozamokból: aktuális kérdések, MNB Szemle, 2009/07, 34-42.

- Ǩezanková, H. [2009]: Cluster analysis and categorical data, Statistika, 216-232.

- Snider, C. - Youle, T. [2010]: Does the LIBOR reflect banks' borrowing costs?, Social Science Research Network, 2010

- Spence, M. [1973]: Job Market Signaling, The Quarterly Journal of Economics, 1973, Vol. 87 (3): 355-374. http://dx.doi.org/10.2307/1882010

- Törvények / kormányrendeletek:

○ 1996. évi CXII. törvény a hitelintézetekről és a pénzügyi vállalkozásokról (hatályos: 2013.12.31)

○ 2007. évi CVI. törvény az állami vagyonról (hatályos: 2013.12.31)

○ 2009. évi IV. törvény a lakáscélú kölcsönökre vonatkozó állami kézfizető kezességről (hatályos: 2013.12.31)

○ 2009. CLXII. törvény a fogyasztónak nyújtott hitelről (hatályos: 2015. február 1-töl)

○ 2014. évi LXXVIII. törvény a fogyasztónak nyújtott hitelről szóló 2009. évi CLXII. törvény és egyes kapcsolódó törvények módosításáról (hatályos: 2015.01.31-ig) 
○ 2011. évi LXXV. törvény a devizakölcsönök törlesztési árfolyamának rögzítéséről és a lakóingatlanok kényszerértékesítésének rendjéröl (hatályos: 2013.12.31)

○ 2013. évi CCXXXVII. törvény a hitelintézetekről és a pénzügyi vállalkozásokról (hatályos: 2014.01.01)

- 215/2000. (XII. 11.) Korm. rendelet a befektetési alapok éves beszámoló készítési és könyvvezetési kötelezettségének sajátosságairól (hatályos: 2013.12.31)

○ 250/2000 (XII. 24.) Kormányrendelet a hitelintézetek és a pénzügyi vállalkozások éves beszámoló készítési és könyvvezetési kötelezettségének sajátosságairól (hatályos: 2013.12.31)

○ 251/2000. (XII. 24.) Kormányrendelet a befektetési vállalkozások éves beszámoló készítési és könyvvezetési kötelezettségének sajátosságairól (hatályos: 2013.12.31)

○ 399/2007 (XII.27.) Korm. rendelet a foglalkoztatói nyugdíjszolgáltató intézmények éves beszámoló készítési és könyvvezetési kötelezettségének sajátosságairól (hatályos: 2013.12.31)

○ 135/2007. (XI. 14.) FVM rendelet a 2007. évben aszálykárt szenvedett mezőgazdasági termelők kedvezményes hitelhez jutási lehetőségéről (hatályos: 2013.12.31)

○ 125/2007. (X. 25.) FVM rendelet a 2007. évi tavaszi fagykár következtében kialakult árbevételkiesés kompenzálására az egyes kereskedelmi vállalkozások által igénybe vehető kedvezményes hitelről (hatályos: 2013.12.31)

○ 94/2007. (IX. 4.) FVM rendelet a biztonságos takarmányellátás érdekében az állattenyésztők részére érvényesíthető csekély összegü (de minimis) támogatás feltételeiröl (hatályos: 2013.12.31)

○ 114/2008. (IX. 5.) FVM rendelet a mezőgazdasági üzemek korszerüsítéséhez, fejlesztéséhez nemzeti hatáskörben nyújtott kedvezményes hitel- és lízingdíjtámogatás igénybevételének részletes feltételeiről (hatályos: 2013.12.31)

○ 29/2009. (VI. 25.) KHEM rendelet a földgázpiaci egyetemes szolgáltatáshoz kapcsolódó árak képzéséről (hatályos: 2013.12.31)

○ 17/2010. (III. 4.) FVM rendelet a családi gazdálkodók által igénybe vehető átmeneti állami támogatásról (hatályos: 2013.12.31)

○ 19/2010. (XII. 3.) NFM rendelet az egyetemes szolgáltatók részére vételre felajánlott földgázforrás és a hazai termelésű földgáz mennyiségéről és áráról, valamint az igénybevételre jogosultak és kötelezettek köréröl (hatályos: 2013.12.31)

- Tirole, J. [2006]: The Theory of Corporate Finance, Princeton, NJ, Princeton University Press

- Treanor, J. - Rusche, D. [2012]: Timothy Geithner and Mervyn King discussed Libor worries in 2008, Guardian, 2012. július 13. http://www.theguardian.com/business/2012/jul/13/tim-geithner-mervyn-king-libor [letöltés: 2014. július 10.]

- United States Departement of Justice (USDJ) [2012a]: Barclays Bank PLC Admits Misconduct Related to Submissions for the London Interbank Offered Rate and the 
Euro Interbank Offered Rate and Agrees to Pay \$160 Million Penalty, USDJ, 2012. június 27. http://www.justice.gov/opa/pr/barclays-bank-plc-admits-misconductrelated-submissions-london-interbank-offered-rate-and [letöltés: 2014. szeptember 10.]

- United States Departement of Justice (USDJ) [2012b]: UBS Securities Japan Co. Ltd. to Plead Guilty to Felony Wire Fraud for Long-running Manipulation of LIBOR Benchmark Interest Rates, USDJ, 2012. december 19. http://www.justice.gov/opa/pr/ubs-securities-japan-co-ltd-plead-guilty-felony-wirefraud-long-running-manipulation-libor [letöltés: 2014. szeptember 10.]

- Vonnák B. [2006]: A magyarországi monetáris transzmissziós mechanizmus fó jellemzői, Közgazdasági Szemle, 2006/12 1155-1177. 


\section{Mellékletek}

\subsection{Melléklet: BUBOR-ra hivatkozó jogszabályok}

- 1996. évi CXII. törvény a hitelintézetekről és a pénzügyi vállalkozásokról (Hpt.) (hatályos 2013.12.31-ig)

„210/B. § (1) Fogyasztóval, ingatlanon alapított jelzálogjog - ideértve az önálló zálogjogként alapított jelzálogjogot is - fedezete mellett kötött kölcsönszerződésre (a továbbiakban: jelzáloghitel-szerződés) a 210. $\S$ (3)-(5), (6)-(7) és (9) bekezdésétől eltérően a (2)-(10) bekezdésben foglaltakat kell alkalmazni.

(3) A jelzáloghitel-szerződés megkötésekor a pénzügyi intézménynek - ha jogszabály másként nem rendelkezik - a kamat változását az alábbi módszerek egyikével kell meghatároznia:

a) referencia-kamatlábhoz kötve, vagy

b) a kamat mértéke a kölcsönszerződésben meghatározott 3 éves, 5 éves vagy 10 éves kamatperiódusok alatt rögzített.

(7) A (3) bekezdés a) pontjában meghatározott esetben a referencia-kamatláb

a) forinthitelnél a 3 havi, a 6 havi vagy a 12 havi BUBOR, vagy a lakáscélú állami támogatásokról szóló kormányrendeletben meghatározottak szerint az Államadósság Kezelő Központ Zrt. által havi rendszerességgel közzétett 3 éves vagy 5 éves állampapír átlaghozam,

b) euróhitelnél és euró alapú hitelnél a 3 havi, a 6 havi vagy a 12 havi EURIBOR,

c) svájci frank hitelnél és svájci frank alapú hitelnél a 3 havi, a 6 havi vagy a 12 havi CHF LIBOR.”91

- 2013. évi CCXXXVII. törvény a hitelintézetekről és a pénzügyi vállalkozásokról (új Hpt.) 280.§ (a hivatkozott paragrafus hatályos 2015. január 31-ig)

„280. § (1) Jelzáloghitel-szerződésre a 279. § (4)-(6), (8)-(9) és (11) bekezdésétől eltérően a (2)-(10) bekezdésben foglaltakat kell alkalmazni.

(3) A jelzáloghitel-szerződés megkötésekor a pénzügyi intézménynek - ha jogszabály másként nem rendelkezik - a kamat változását az alábbi módszerek egyikével kell meghatároznia:

a) referencia-kamatlábhoz kötve, vagy

b) a kamat mértéke a kölcsönszerződésben meghatározott 3 éves, 5 éves vagy 10 éves kamatperiódusok alatt rögzített.

(7) A (3) bekezdés a) pontjában meghatározott esetben a referencia-kamatláb

a) forinthitelnél a 3 havi, a 6 havi vagy a 12 havi BUBOR, vagy a lakáscélú állami támogatásokról szóló kormányrendeletben meghatározottak szerint az Államadósság Kezelő Központ Zrt. által havi rendszerességgel közzétett 3 éves vagy 5 éves állampapír átlaghozam,

\footnotetext{
${ }^{91}$ 2014.01.01-töl 2013. évi CCXXXVII. törvény 280.§.
} 
b) euróhitelnél és euró alapú hitelnél a 3 havi, a 6 havi vagy a 12 havi EURIBOR,

c) svájci frank hitelnél és svájci frank alapú hitelnél a 3 havi, a 6 havi vagy a 12 havi CHF LIBOR.”

- 2011. évi LXXV. törvény a devizakölcsönök törlesztési árfolyamának rögzítéséről és a lakóingatlanok kényszerértékesítésének rendjéről

„4. § (1) A gyüjtőszámlahitelre vonatkozó hitelkeret-szerződésnek a következő feltételeknek kell megfelelnie:

...

c) a gyüjtőszámlahitel háromhavonta tőkésíthető, három hónapos kamatperiódusra meghatározott ügyleti kamata nem haladhatja meg

ca) a rögzített árfolyam alkalmazási időszaka záró időpontjáig a kamatperiódus kezdő időpontjával érintett hónap első napján érvényes 3 havi BUBOR mindenkor aktuális mértékét, ...”

- 2009. évi IV. törvény a lakáscélú kölcsönökre vonatkozó állami kézfizető kezességről

„2. § (1) A Magyar Állam a központi költségvetés terhére készfizető kezesként felel $\cdots$

d) a pénzügyi intézmény a hitelszerződés aláírását követő huszonnegyedik hónap utolsó napjáig fizetési kötelezettséget nem írhat elö,

e) a természetes személy az áthidaló kölcsönre a $d$ ) pontban meghatározott időpontot követően legfeljebb a három havi BUBOR-nak (Budapest Interbank Offered Rate) megfelelő mértékü kamatot fizet, azzal, hogy a pénzügyi intézmény a kamat mértékét első alkalommal a $d$ ) pontban meghatározott időpontban, ezt követően évente állapítja meg, ..."

\section{- 2007. évi CVI. törvény az állami vagyonról}

„68. § (1) Az országgyülési képviselők általános választásán országos listát állító és az Országgyülésben képviselőcsoport alakítására is jogosultságot szerző párt részére, a párt müködési feltételeinek biztosítása érdekében iroda rendeltetésű ingatlan vásárlásához a Magyar Fejlesztési Bank Zrt. a párt kezdeményezésére a (2) és (3) bekezdés szerinti feltételekkel pénzkölcsönt nyújt.

(3) Az állami kezességvállalás mellett, három havi Bubor $+1 \%$-os kamattal nyújtott pénzkölcsön nem haladhatja meg az érintett ingatlanok igazságügyi ingatlanforgalmi szakértő által meghatározott becsült forgalmi értékét, ..."

- 399/2007 (XII.27.) Kormányrendelet a foglalkoztatói nyugdíjszolgáltató intézmények éves beszámoló készítési és könyvvezetési kötelezettségének sajátosságairól

„7. § (1) Az intézmény mérlegbeli és mérlegen kívüli tételeinek értékelésére az Szt.-ben előírt szabályokat a

(2)-(12) bekezdésben és a 8 . §-ban foglaltak figyelembevételével alkalmazza.

(7) A piaci érték meghatározásánál figyelembe kell venni: ... 
e) a származékos ügylet tárgyát képező pénzügyi instrumentumnál, egyéb árunál (a származékos ügylet értékelése tekintetében)

ec) tőzsdén kívüli kamatlábügyletek (kamatalapú határidős és swap ügyletek) esetén a változó kamatláb mértékét, amely a szerződésben rögzített irányadó kamatláb, ennek hiányában a szerződés szerinti időszakra vonatkozó BUBOR értékelés napját megelőzően utoljára közzétett mértéke, vagy az értékelés napján érvényes határidős piaci kamatláb mértéke,..."

- 251/2000. (XII. 24.) Kormányrendelet a befektetési vállalkozások éves beszámoló készítési és könyvvezetési kötelezettségének sajátosságairól

„14. § (6) A (3) bekezdés szerinti, a mérleg fordulónapján ismert piaci értéknek kell tekinteni: ...

c) tőzsdén kívüli kamatlábügyletek (kamatalapú határidős és swap ügyletek) esetén a szerződésben rögzített irányadó kamatláb, ennek hiányában a szerződés szerinti időtartamra vonatkozó BUBOR üzleti évben utoljára közzétett mértékét vagy a mérleg fordulónapján érvényes határidős piaci kamatláb mértékét, ...”

- 250/2000 (XII. 24.) Kormányrendelet a hitelintézetek és a pénzügyi vállalkozások éves beszámoló készítési és könyvvezetési kötelezettségének sajátosságairól

„14. § (6) A (3) bekezdés szerinti, a mérleg fordulónapján ismert piaci értéknek kell tekinteni:

c) tőzsdén kívüli kamatlábügyletek (kamatalapú határidős és swap ügyletek) esetén a szerződésben rögzített irányadó kamatláb, ennek hiányában a szerződés szerinti időtartamra vonatkozó BUBOR üzleti évben utoljára közzétett mértékét vagy a mérleg fordulónapján érvényes határidős piaci kamatláb mértékét, ...”

- 215/2000. (XII. 11.) Korm. rendelet a befektetési alapok éves beszámoló készítési és könyvvezetési kötelezettségének sajátosságairól

„7.§ (5) A származtatott ügyletek piaci értékének meghatározásakor az ügylet tárgyát képező pénzügyi instrumentum, egyéb áru piaci árának meghatározásakor figyelembe kell venni többek között:

c) tőzsdén kívüli kamatlábügyletek (kamatalapú határidős és swap ügyletek) esetén a változó kamatláb a szerződésben rögzített irányadó kamatláb, ennek hiányában a szerződés szerinti időszakra vonatkozó BUBOR értékelés napját megelőzően utoljára közzétett mértékét, vagy az értékelés napján érvényes határidős piaci kamatláb mértéke; ..."

- 17/2010. (III. 4.) FVM rendelet a családi gazdálkodók által igénybe vehető átmeneti állami támogatásról

„1. $§$ E rendelet alkalmazásában: 
2. hitel: a családi gazdálkodó által a 317/2001. (XII. 29.) Korm. rendelet alapján a gazdálkodásához igénybe vett rulírozó jellegü forgóeszköz hitel lejáratkor a fennálló hitelének tőkeösszege alapján a Magyar Fejlesztési Bank Zártkörüen Működő Részvénytársaság által kihelyezett, és az eredeti véglejárat futamidejének meghosszabbítását követő naptól meghatározott háromhavi BUBOR+3,1-7\% közötti mértékü, piaci kamatozású, éven túli lejáratú forgóeszköz hitel; ...”

- 29/2009. (VI. 25.) KHEM rendelet a földgázpiaci egyetemes szolgáltatáshoz kapcsolódó árak képzéséről

„6.§ (5)A 3. § (1) bekezdés e) pontja szerinti mobilgáz-finanszírozási költség a betárolt földgázmennyiségre negyedévente frissített, az aktuális negyedévet megelőző negyedév második hónapjának 1. és 15 . napja közötti időszak banki napjain jegyzett hathavi BUBOR bankközi kamatláb átlaga +75 bázisponton számított finanszírozási költség. A Hivatal az alkalmazandó mobilgáz-finanszírozási költséget és az azt megalapozó számítást honlapján közzéteszi."

- 19/2010. (XII. 3.) NFM rendelet az egyetemes szolgáltatók részére vételre felajánlott földgázforrás és a hazai termelésü földgáz mennyiségéről és áráról, valamint az igénybevételre jogosultak és kötelezettek köréről

„4.§ (8) Amennyiben az adott negyedévben az egyetemes szolgáltató és a volt közüzemi nagykereskedő a 24. mellékletben meghatározott földgáz mennyiséget közvetve vagy közvetlenül nem az egyetemes szolgáltatásra jogosult felhasználók ellátására használja, és így a volt közüzemi nagykereskedőnek vagy a termelőnek vesztesége keletkezik, az árszabályozás során a felajánlási ár megállapításakor ez a veszteség kamattal (tárgyidőszakra vonatkozó BUBOR) növelt összege figyelembevételre kerül.”

- 2009. CLXII. törvény a fogyasztónak nyújtott hitelről 17/C. §. és 17/D. §. (a hivatkozott paragrafusok hatályosak 2015. február 1-től).

„17/C. § (1) A legfeljebb 3 éves futamidejü hitel annak teljes futamidejére a hitelszerződésben meghatározott

a) fix kamatozással, vagy

b) a Magyar Nemzeti Bank honlapján közzétett referencia-kamatlábhoz kötött változó kamatozással és fix kamatfelárral

nyújtható, és e hitel kamatfeltételei a fogyasztó számára hátrányosan egyoldalúan nem módosíthatók.

(2) A 3 évet meghaladó futamidejü hitel a szerződésben meghatározott,

a) a Magyar Nemzeti Bank honlapján közzétett referencia-kamatlábhoz kötött változó kamatozással és annak teljes futamidejére vagy legalább 3 éves kamatperiódusokban rögzített kamatfelárral,

b) legalább 3 éves kamatperiódusokban rögzített hitelkamattal, vagy

c) fix kamatozással

nyújtható.

(3) A (2) bekezdés szerinti hitel utolsó kamatperiódusának időtartama 3 évnél rövidebb is lehet. 
17/D. § (1) Referencia-kamatlábhoz kötött kamatozású hitelszerződés esetén a referencia-kamatláb mértékét a hitelszerződésben meghatározott referenciakamat futamidejének megfelelő időközönként kell a fordulónapot megelőző hónap utolsó munkanapja előtt 2 nappal érvényes referencia-kamatlábhoz igazítani.

(2) A hitelező a hitel futamideje alatt legfeljebb öt alkalommal az egyes kamatperiódusok lejárta után

a) a hitelkamatot legfeljebb a szerződésben meghatározott, a Magyar Nemzeti Bank honlapján közzétett kamatváltoztatási mutató,

b) a kamatfelárat legfeljebb a szerződésben meghatározott, a Magyar Nemzeti Bank honlapján közzétett kamatfelár-változtatási mutató

alkalmazásával számított mértékig módosíthatja.

(3) Ha a hitelező a (2) bekezdés szerinti kamatmódosítás során a kamatváltoztatási, illetve a kamatfelárváltoztatási mutató által lehetővé tett mértéknél kedvezőbb hitelkamatot, illetve kamatfelárat alkalmazott, a későbbi kamatperiódusokban a kamat, illetve a kamatfelár mértéke tekintetében adott kedvezményt - annak erejéig - a csökkentendő kamat, illetve kamatfelár mértékébe betudhatja.

(4) Ha a hitelező a kamat, illetve kamatfelár módosítása során a Magyar Nemzeti Bank által közzé nem tett kamatváltoztatási, illetve kamatfelár-változtatási mutatót, vagy referencia-kamatlábat kíván alkalmazni, úgy ezt - annak az (5) bekezdés szerinti bemutatásával - a Magyar Nemzeti Banknak köteles előzetesen bejelenteni. Ha a bejelentett kamatváltoztatási, kamatfelár-változtatási mutató vagy referencia-kamatláb az e törvényben foglalt követelményeknek megfelel, azt a Magyar Nemzeti Bank a honlapján a bejelentéstől számított 30 napon belül közzéteszi, ellenkező esetben a közzétételt a felügyeleti jogkörében hozott határozatával elutasítja.

(5) A kamatváltoztatási, kamatfelár-változtatási mutatót vagy referencia-kamatlábat az alkalmazásának feltételeivel együtt, közérthető magyarázattal ellátva kell bejelenteni, és annak közzétételéröl is ilyen módon kell gondoskodni.

(6) Az alkalmazni kívánt kamatváltoztatási, kamatfelár-változtatási mutatót vagy referencia-kamatlábat a hitelszerződésben kell meghatározni és az - ideértve annak bármely összetevőjét is - a kamatperiódust követően sem módosítható egyoldalúan. Abban az esetben azonban, ha a kamatváltoztatási, kamatfelárváltoztatási mutató vagy referencia-kamatláb a kialakítását meghatározó körülményekben bekövetkezett lényeges változás miatt a rendeltetésére alkalmatlanná vált, a Magyar Nemzeti Bank azt a honlapjáról törli és egyidejűleg megjelöli az azt helyettesítő kamatváltoztatási, kamatfelár-változtatási mutatót vagy referencia-kamatlábat." 


\subsection{Melléklet: Az 1, 3 és 6 havi BUBOR jegyzések szórásának az idősora} (bázispont)

33. ábra: Az 1 havi BUBOR jegyzések szórásának idősora 2004. január - 2012. június

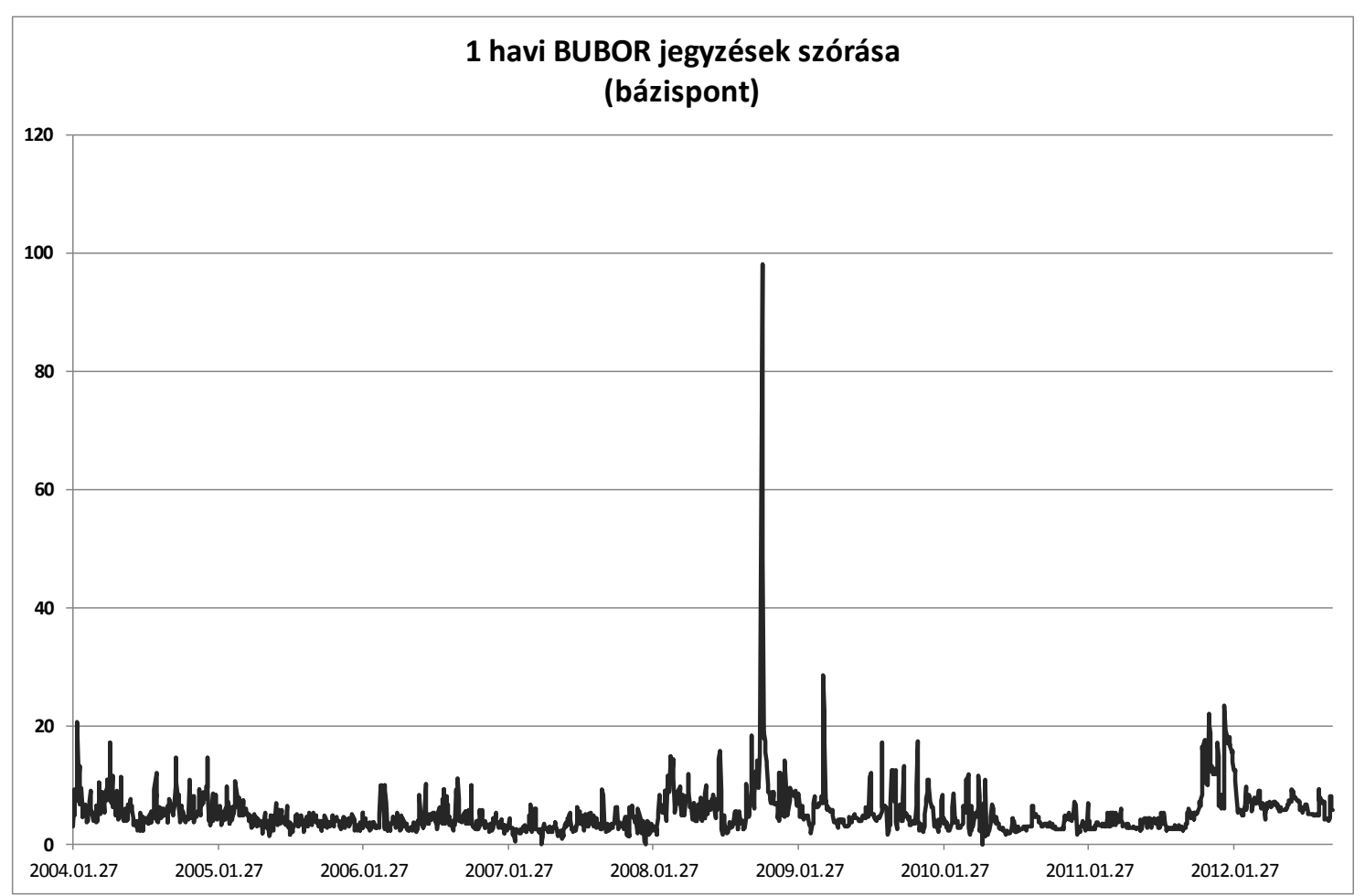

forrás: $M N B$, saját szerkesztés 
34. ábra: A 3 havi BUBOR jegyzések szórásának idősora 2004. január - 2012. június

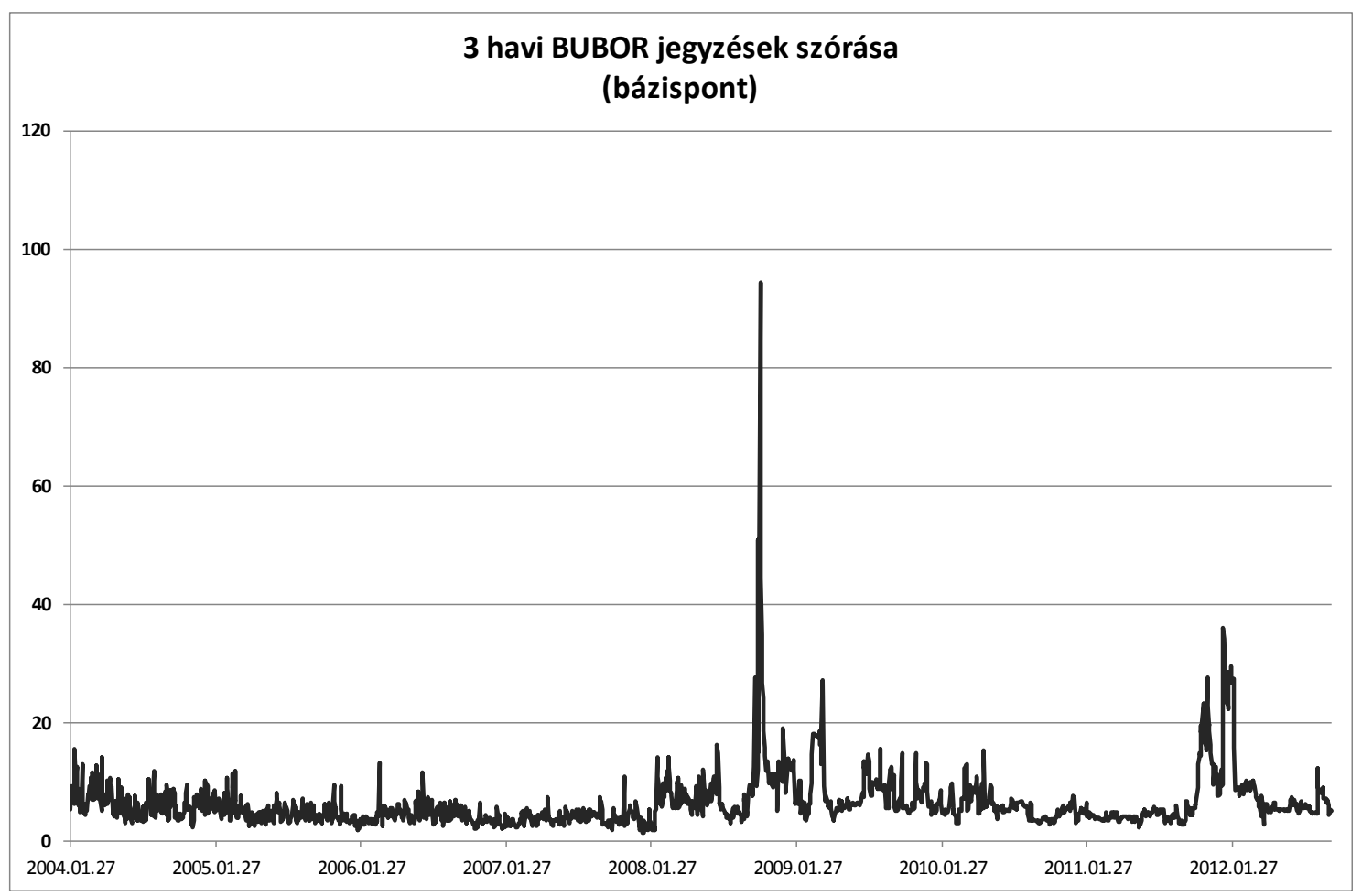

forrás: $M N B$, saját szerkesztés

35. ábra: A 6 havi BUBOR jegyzések szórásának idősora 2004. január - 2012. június

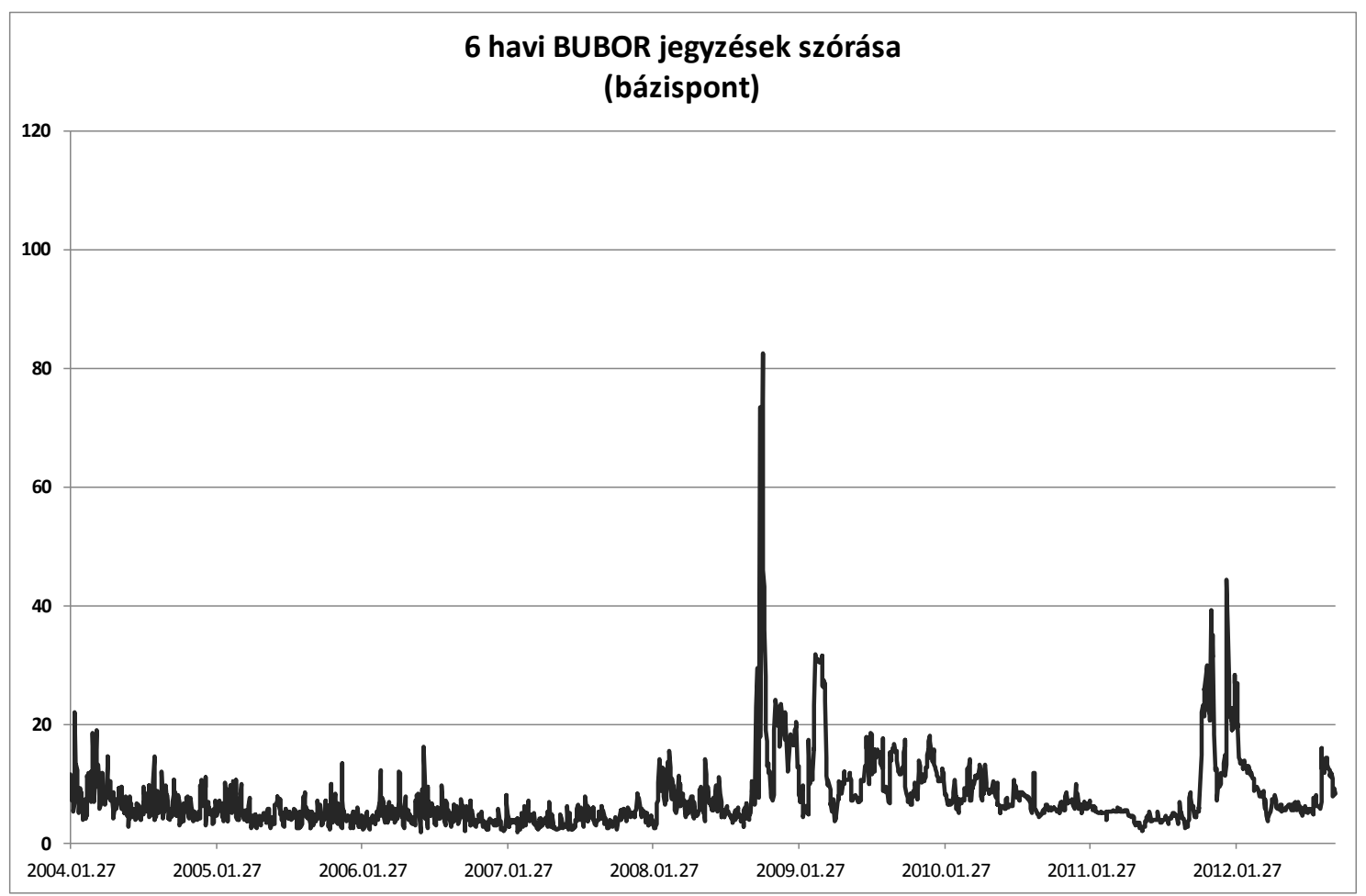

forrás: $M N B$, saját szerkesztés 


\subsection{Melléklet: A jegybanki alapkamat és az 1, 3 és 6 havi BUBOR értékek} (1M, 3M, 6M) idősorának korrelációs mátrixai 2004. január - 2012. június időszakra

Az időszak a korreláció számításához figyelembe vett idősort jelöli. P1. 2007 a 2007.01.012007.12.31 közötti kereskedési napokat tartalmazza. az elemzés során az első korrelációs mátrix idősorait hat diszjunkt részre osztottuk és ezen halmazokon is vizsgáltuk a korrelációkat. (Az adatok forrása: MNB.)

\begin{tabular}{|c|c|c|c|c|c|}
\hline Időszak & \multicolumn{5}{|c|}{ Korrelációs mátrix } \\
\hline \multirow{5}{*}{ 2004-2012 } & & $1 M$ & $3 M$ & $6 M$ & Alapkamat \\
\hline & $1 \mathrm{M}$ & 1 & & & \\
\hline & $3 M$ & 0,996028 & 1 & & \\
\hline & $6 M$ & 0,985886 & 0,996573 & 1 & \\
\hline & Alapkamat & 0,998158 & 0,991789 & 0,979612 & 1 \\
\hline \multirow{5}{*}{2007} & & $1 M$ & $3 M$ & $6 M$ & Alapkamat \\
\hline & $1 M$ & 1 & & & \\
\hline & $3 M$ & 0,935696 & 1 & & \\
\hline & $6 M$ & 0,860721 & 0,980794 & 1 & \\
\hline & Alapkamat & 0,986985 & 0,883068 & 0,790366 & 1 \\
\hline \multirow{5}{*}{2008} & & $1 M$ & $3 M$ & $6 M$ & Alapkamat \\
\hline & $1 M$ & 1 & & & \\
\hline & $3 M$ & 0,994396 & 1 & & \\
\hline & $6 M$ & 0,983012 & 0,996156 & 1 & \\
\hline & Alapkamat & 0,986005 & 0,976154 & 0,962362 & 1 \\
\hline \multirow{5}{*}{2009} & & $1 M$ & $3 M$ & $6 M$ & Alapkamat \\
\hline & $1 \mathrm{M}$ & 1 & & & \\
\hline & $3 M$ & 0,999129 & 1 & & \\
\hline & $6 \mathrm{M}$ & 0,997467 & 0,999414 & 1 & \\
\hline & Alapkamat & 0,999024 & 0,997117 & 0,99487 & 1 \\
\hline \multirow{5}{*}{2010} & & $1 M$ & $3 M$ & $6 M$ & Alapkamat \\
\hline & $1 \mathrm{M}$ & 1 & & & \\
\hline & $3 M$ & 0,987369 & 1 & & \\
\hline & $6 M$ & 0,9375 & 0,9792 & 1 & \\
\hline & Alapkamat & 0,998633 & 0,984317 & 0,932105 & 1 \\
\hline
\end{tabular}




\begin{tabular}{|c|c|c|c|c|c|}
\hline \multirow{5}{*}{2011} & & $1 M$ & $3 M$ & $6 M$ & Alapkamat \\
\hline & $1 M$ & 1 & & & \\
\hline & $3 M$ & 0,983983 & 1 & & \\
\hline & $6 M$ & 0,956152 & 0,991014 & 1 & \\
\hline & Alapkamat & 0,970345 & 0,926123 & 0,878615 & 1 \\
\hline \multirow{5}{*}{2012} & & $1 M$ & $3 M$ & $6 M$ & Alapkamat \\
\hline & $1 M$ & 1 & & & \\
\hline & $3 M$ & 0,931561 & 1 & & \\
\hline & $6 M$ & 0,885227 & 0,989448 & 1 & \\
\hline & Alapkamat & 0,940729 & 0,775278 & 0,694234 & 1 \\
\hline
\end{tabular}

\subsection{Melléklet: A változók korrelációs mátrixa (transzformált változók)}

\begin{tabular}{|c|c|c|c|c|c|c|c|c|c|c|c|c|c|}
\hline \multicolumn{14}{|c|}{ Correlations } \\
\hline & & EUR & $\mathrm{CHF}$ & USD & CDS & swap_3m & swap_6m & FRA_3x6 & FRA_6x12 & Alapkamat & DKJ & Hufonia & Piacijavak \\
\hline EUR & \begin{tabular}{|l|} 
Pearson \\
Correlation
\end{tabular} & 1 &, 774 & ,858" & ,715" & ,032 & ,487" & ,673" & ,726" &,- 032 & , 385" & ,018 &,- 033 \\
\hline $\mathrm{CHF}$ & $\begin{array}{l}\text { Pearson } \\
\text { Correlation }\end{array}$ & & 1 & ,732" & ,686" & ,058 & ,405" &, $539^{*}$ & ,595" & ,026 & , 363" &,- 043 &,- 055 \\
\hline USD & $\begin{array}{l}\text { Pearson } \\
\text { Correlation }\end{array}$ & & & 1 & ,734" & ,052 & , $445^{\prime \prime}$ & $600^{*}$ & ,642" & -,006 & ,398" &,- 003 & -050 \\
\hline CDS & $\begin{array}{l}\text { Pearson } \\
\text { Correlation }\end{array}$ & & & & 1 & , 188" & ,539" & ,650" & ,683" & ,122" & ,507" & ,044 &,- 043 \\
\hline swap_3m & $\begin{array}{l}\text { Pearson } \\
\text { Correlation }\end{array}$ & & & & & 1 & ,793" &, $502^{*}$ & , 333" & ,924" & ,681" &,$- 094^{* *}$ & ,082 \\
\hline swap_6m & $\begin{array}{l}\text { Pearson } \\
\text { Correlation }\end{array}$ & & & & & & 1 & ,921" & ,815" & ,689" & ,852" & - & ,089" \\
\hline FRA_3x6 & $\begin{array}{l}\text { Pearson } \\
\text { Correlation }\end{array}$ & & & & & & & 1 & ,955" & ,402" & , 781" & -,032 & ,056 \\
\hline FRA_6x12 & $\begin{array}{l}\text { Pearson } \\
\text { Correlation }\end{array}$ & & & & & & & & 1 & ,238" & ,735" & -,022 & ,031 \\
\hline Alapkamat & $\begin{array}{l}\mathrm{t} \text { Pearson } \\
\text { Correlation }\end{array}$ & & & & & & & & & 1 & ,573* & -,046 & ,065 \\
\hline DKJ & $\begin{array}{l}\text { Pearson } \\
\text { Correlation }\end{array}$ & & & & & & & & & & 1 &,$- 082^{*}$ & 166" \\
\hline Hufonia & $\begin{array}{l}\text { Pearson } \\
\text { Correlation }\end{array}$ & & & & & & & & & & & 1 & 157" \\
\hline Piacijavak & $\begin{array}{l}\text { Pearson } \\
\text { Correlation }\end{array}$ & & & & & & & & & & & & 1 \\
\hline
\end{tabular}




\subsection{Melléklet: A klasztermodellek eredményeinek összevetése a tényadatokkal - kereszttáblák}

„A” bank

\begin{tabular}{|c|c|c|c|c|}
\hline \multirow{2}{*}{\multicolumn{2}{|c|}{ 3M jegyzések (db) }} & \multicolumn{3}{|c|}{ klas zterek } \\
\hline & & \multirow{2}{*}{$\frac{\mathrm{a}}{58}$} & \multirow{2}{*}{$\frac{b}{73}$} & \multirow{2}{*}{$\frac{\mathrm{c}}{122}$} \\
\hline kontrollváltozó & -1 & & & \\
\hline kategória & 0 & 87 & 243 & 237 \\
\hline & 1 & 5 & 26 & 10 \\
\hline
\end{tabular}

\begin{tabular}{|c|c|c|c|c|}
\hline \multirow{2}{*}{\multicolumn{2}{|c|}{$\begin{array}{c}3 \mathrm{M} \text { jegyzések (\% kontroll } \\
\text { kategóriánként) }\end{array}$}} & \multicolumn{3}{|c|}{ klaszterek } \\
\hline & & a & b & $\mathrm{c}$ \\
\hline \multirow{3}{*}{$\begin{array}{l}\text { kontrollváltozó } \\
\text { kategória }\end{array}$} & -1 & $23 \%$ & $29 \%$ & $48 \%$ \\
\hline & 0 & $15 \%$ & $43 \%$ & $42 \%$ \\
\hline & 1 & $12 \%$ & $63 \%$ & $24 \%$ \\
\hline
\end{tabular}

\begin{tabular}{|c|c|c|c|c|}
\hline \multirow{2}{*}{\multicolumn{2}{|c|}{$6 \mathrm{M}$ jegyzések (db) }} & \multicolumn{3}{|c|}{ klas zterek } \\
\hline & & \multirow{2}{*}{$\frac{\mathrm{a}}{12}$} & \multirow{2}{*}{$\frac{b}{191}$} & \multirow{2}{*}{$\frac{\mathrm{c}}{160}$} \\
\hline kontrollváltozó & -1 & & & \\
\hline kategória & 0 & 21 & 238 & 178 \\
\hline & 1 & 0 & 14 & 47 \\
\hline
\end{tabular}

\begin{tabular}{|l|c|ccc|}
\hline \multirow{2}{*}{$\begin{array}{c}\text { 6M jegyzések (\% kontroll } \\
\text { kategóriánként) }\end{array}$} & \multicolumn{3}{|c|}{ klas zterek } \\
\cline { 2 - 5 } kontrollváltozó & -1 & $3 \%$ & $53 \%$ & $44 \%$ \\
kategória & 0 & $5 \%$ & $54 \%$ & $41 \%$ \\
& 1 & $0 \%$ & $23 \%$ & $77 \%$ \\
\hline
\end{tabular}

„B” bank

\begin{tabular}{|c|c|c|c|c|}
\hline \multirow{2}{*}{\multicolumn{2}{|c|}{ 3M jegyzések (db) }} & \multicolumn{3}{|c|}{ klas zterek } \\
\hline & & \multirow{2}{*}{$\frac{\mathrm{a}}{28}$} & \multirow{2}{*}{$\frac{b}{70}$} & \multirow{2}{*}{$\frac{\mathrm{c}}{94}$} \\
\hline kontrollváltozó & -1 & & & \\
\hline kategória & 0 & 100 & 197 & 220 \\
\hline & 1 & 67 & 61 & 24 \\
\hline
\end{tabular}

\begin{tabular}{|l|c|ccc|}
\hline \multirow{2}{*}{$\begin{array}{c}3 \text { M jegyzések (\% kontroll } \\
\text { kategóriánként) }\end{array}$} & \multicolumn{3}{|c|}{ klaszterek } \\
\cline { 2 - 5 } & $\mathrm{a}$ & $\mathrm{b}$ & $\mathrm{c}$ \\
\hline $\begin{array}{l}\text { kontrollválttozó } \\
\text { kategória }\end{array}$ & -1 & $15 \%$ & $36 \%$ & $49 \%$ \\
& 0 & $19 \%$ & $38 \%$ & $43 \%$ \\
& 1 & $44 \%$ & $40 \%$ & $16 \%$ \\
\hline
\end{tabular}

\begin{tabular}{|c|c|c|c|c|}
\hline \multirow{2}{*}{\multicolumn{2}{|c|}{$6 \mathrm{M}$ jegyzések (db) }} & \multicolumn{3}{|c|}{ klas zterek } \\
\hline & & \multirow{2}{*}{$\frac{a}{42}$} & \multirow{2}{*}{$\frac{b}{68}$} & \multirow{2}{*}{$\frac{\mathrm{c}}{138}$} \\
\hline kontrollváltozó & -1 & & & \\
\hline kategória & 0 & 81 & 189 & 203 \\
\hline & 1 & 8 & 71 & 61 \\
\hline
\end{tabular}

\begin{tabular}{|l|c|ccc|}
\hline \multirow{2}{*}{$\begin{array}{c}\text { 6M jegyzések (\% kontroll } \\
\text { kategóriánként) }\end{array}$} & \multicolumn{3}{|c|}{ klaszterek } \\
\cline { 2 - 5 } & $\mathrm{a}$ & $\mathrm{b}$ & $\mathrm{c}$ \\
\hline kontrollváltozó & -1 & $17 \%$ & $27 \%$ & $56 \%$ \\
kategória & 0 & $17 \%$ & $40 \%$ & $43 \%$ \\
& 1 & $6 \%$ & $51 \%$ & $44 \%$ \\
\hline
\end{tabular}

„C” bank

\begin{tabular}{|l|r|rc|c|}
\hline \multirow{2}{*}{$3 \mathrm{M}$ jegyzések $(\mathrm{db})$} & \multicolumn{3}{|c|}{ klaszterek } \\
\cline { 2 - 5 } & $\mathrm{a}$ & $\mathrm{b}$ & $\mathrm{c}$ \\
\hline kontrollváltozó & -1 & 21 & 18 & 45 \\
kategória & 0 & 235 & 51 & 302 \\
& 1 & 80 & 15 & 94 \\
\hline
\end{tabular}

\begin{tabular}{|c|c|c|c|c|}
\hline \multirow{2}{*}{\multicolumn{2}{|c|}{$\begin{array}{c}3 \mathrm{M} \text { jegyzések (\% kontroll } \\
\text { kategóriánként) }\end{array}$}} & \multicolumn{3}{|c|}{ klaszterek } \\
\hline & & \multirow{2}{*}{$\frac{\mathrm{a}}{25 \%}$} & \multirow{2}{*}{$\frac{\mathrm{b}}{21 \%}$} & \multirow{2}{*}{$\frac{\mathrm{c}}{54 \%}$} \\
\hline \multirow{3}{*}{$\begin{array}{l}\text { kontrollváltozó } \\
\text { kategória }\end{array}$} & -1 & & & \\
\hline & 0 & $40 \%$ & $9 \%$ & $51 \%$ \\
\hline & 1 & $42 \%$ & $8 \%$ & $50 \%$ \\
\hline
\end{tabular}

\begin{tabular}{|c|c|c|c|c|}
\hline \multirow{2}{*}{\multicolumn{2}{|c|}{ 6M jegyzések (db) }} & \multicolumn{3}{|c|}{ klas zterek } \\
\hline & & \multirow{2}{*}{$\frac{\mathrm{a}}{89}$} & \multirow{2}{*}{$\frac{b}{0}$} & \multirow{2}{*}{$\frac{c}{70}$} \\
\hline kontrollváltozó & -1 & & & \\
\hline kategória & 0 & 307 & 10 & 183 \\
\hline & 1 & 76 & 4 & 122 \\
\hline
\end{tabular}

\begin{tabular}{|l|c|c|c|c|}
\hline \multirow{2}{*}{$\begin{array}{c}\text { 6M jegyzések (\% kontroll } \\
\text { kategóriánként) }\end{array}$} & \multicolumn{3}{|c|}{ klas zterek } \\
\cline { 2 - 5 } & $\mathrm{a}$ & $\mathrm{b}$ & $\mathrm{c}$ \\
\hline kontrollváltozó & -1 & $56 \%$ & $0 \%$ & $44 \%$ \\
kategória & 0 & $61 \%$ & $2 \%$ & $37 \%$ \\
& 1 & $38 \%$ & $2 \%$ & $60 \%$ \\
\hline
\end{tabular}


„D” bank

\begin{tabular}{|c|c|c|c|c|}
\hline \multirow{2}{*}{\multicolumn{2}{|c|}{ 3M jegyzések (db) }} & \multicolumn{3}{|c|}{ klas zterek } \\
\hline & & \multirow{2}{*}{$\frac{\mathrm{a}}{28}$} & \multirow{2}{*}{$\frac{\mathrm{b}}{86}$} & \multirow{2}{*}{$\frac{c}{25}$} \\
\hline kontrollváltozó & -1 & & & \\
\hline kategória & 0 & 178 & 303 & 113 \\
\hline & 1 & 77 & 35 & 16 \\
\hline
\end{tabular}

\begin{tabular}{|l|c|ccc|}
\hline \multirow{2}{*}{$\begin{array}{c}3 \text { M jegyzések (\% kontroll } \\
\text { kategóriánként) }\end{array}$} & \multicolumn{3}{|c|}{ klaszterek } \\
\cline { 2 - 5 } kontrollváltozó & -1 & $\mathrm{a}$ & $\mathrm{b}$ & $\mathrm{c}$ \\
\hline kategória & 0 & $30 \%$ & $62 \%$ & $18 \%$ \\
& 1 & $60 \%$ & $27 \%$ & $13 \%$ \\
\hline
\end{tabular}

\begin{tabular}{|c|c|c|c|c|}
\hline \multirow{2}{*}{\multicolumn{2}{|c|}{ 6M jegyzések (db) }} & \multicolumn{3}{|c|}{ klaszterek } \\
\hline & & \multirow{2}{*}{$\frac{a}{54}$} & \multirow{2}{*}{$\frac{b}{55}$} & \multirow{2}{*}{$\frac{c}{104}$} \\
\hline kontrollváltozó & -1 & & & \\
\hline kategória & 0 & 107 & 80 & 317 \\
\hline & 1 & 103 & 18 & 23 \\
\hline
\end{tabular}

\begin{tabular}{|l|c|ccc|}
\hline \multirow{2}{*}{$\begin{array}{c}\text { 6M jegyzések (\% kontroll } \\
\text { kategóriánként) }\end{array}$} & \multicolumn{3}{|c|}{ klaszterek } \\
\cline { 2 - 5 } kontrollválttozó & -1 & $25 \%$ & $26 \%$ & $49 \%$ \\
kategória & 0 & $21 \%$ & $16 \%$ & $63 \%$ \\
& 1 & $72 \%$ & $13 \%$ & $16 \%$ \\
\hline
\end{tabular}

„E” bank

\begin{tabular}{|c|c|c|c|c|}
\hline \multirow{2}{*}{\multicolumn{2}{|c|}{ 3M jegyzések (db) }} & \multicolumn{3}{|c|}{ klas zterek } \\
\hline & & \multirow{2}{*}{$\frac{a}{26}$} & \multirow{2}{*}{$\frac{b}{7}$} & \multirow{2}{*}{$\frac{c}{33}$} \\
\hline kontrollváltozó & -1 & & & \\
\hline kategória & 0 & 355 & 115 & 267 \\
\hline & 1 & 28 & 18 & 12 \\
\hline
\end{tabular}

\begin{tabular}{|c|c|c|c|c|}
\hline \multirow{2}{*}{\multicolumn{2}{|c|}{$\begin{array}{c}3 \mathrm{M} \text { jegyzések (\% kontroll } \\
\text { kategóriánként) }\end{array}$}} & \multicolumn{3}{|c|}{ klaszterek } \\
\hline & & $\mathrm{a}$ & $b$ & $\mathrm{c}$ \\
\hline \multirow{3}{*}{$\begin{array}{l}\text { kontrollváltozó } \\
\text { kategória }\end{array}$} & -1 & $39 \%$ & $11 \%$ & $50 \%$ \\
\hline & 0 & $48 \%$ & $16 \%$ & $36 \%$ \\
\hline & 1 & $48 \%$ & $31 \%$ & $21 \%$ \\
\hline
\end{tabular}

\begin{tabular}{|c|c|c|c|c|}
\hline \multirow{2}{*}{\multicolumn{2}{|c|}{$6 \mathrm{M}$ jegyzések (db) }} & \multicolumn{3}{|c|}{ klas zterek } \\
\hline & & \multirow{2}{*}{$\frac{a}{22}$} & \multirow{2}{*}{$\frac{b}{22}$} & \multirow{2}{*}{$\frac{c}{28}$} \\
\hline kontrollváltozó & -1 & & & \\
\hline kategória & 0 & 386 & 202 & 104 \\
\hline & 1 & 32 & 44 & 21 \\
\hline
\end{tabular}

\begin{tabular}{|l|c|ccc|}
\hline \multirow{2}{*}{$\begin{array}{c}\text { 6M jegyzések (\% kontroll } \\
\text { kategóriánként) }\end{array}$} & \multicolumn{3}{|c|}{ klaszterek } \\
\cline { 2 - 5 } $\begin{array}{l}\text { kontrollválttozó } \\
\text { kategória }\end{array}$ & -1 & $31 \%$ & $31 \%$ & $39 \%$ \\
& 0 & $56 \%$ & $29 \%$ & $15 \%$ \\
& 1 & $33 \%$ & $45 \%$ & $22 \%$ \\
\hline
\end{tabular}

„F” bank

\begin{tabular}{|c|c|c|c|c|}
\hline \multirow{2}{*}{\multicolumn{2}{|c|}{ 3M jegyzések (db) }} & \multicolumn{3}{|c|}{ klas zterek } \\
\hline & & \multirow{2}{*}{$\frac{\mathrm{a}}{182}$} & \multirow{2}{*}{$\frac{b}{56}$} & \multirow{2}{*}{$\frac{\mathrm{c}}{134}$} \\
\hline kontrollváltozó & -1 & & & \\
\hline kategória & 0 & 126 & 78 & 196 \\
\hline & 1 & 38 & 9 & 42 \\
\hline
\end{tabular}

\begin{tabular}{|c|c|c|c|c|}
\hline \multirow{2}{*}{\multicolumn{2}{|c|}{$\begin{array}{c}\text { 3M jegyzések (\% kontroll } \\
\text { kategóriánként) }\end{array}$}} & \multicolumn{3}{|c|}{ klas zterek } \\
\hline & & \multirow{2}{*}{$\frac{\mathrm{a}}{49 \%}$} & \multirow{2}{*}{$\frac{\mathrm{b}}{15 \%}$} & \multirow{2}{*}{$\frac{\mathrm{c}}{36 \%}$} \\
\hline kontrollváltozó & -1 & & & \\
\hline kategória & 0 & $32 \%$ & $20 \%$ & $49 \%$ \\
\hline & 1 & $43 \%$ & $10 \%$ & $47 \%$ \\
\hline
\end{tabular}

\begin{tabular}{|c|c|c|c|c|}
\hline \multirow{2}{*}{\multicolumn{2}{|c|}{$6 \mathrm{M}$ jegyzések (db) }} & \multicolumn{3}{|c|}{ klas zterek } \\
\hline & & \multirow{2}{*}{$\frac{a}{41}$} & \multirow{2}{*}{$\frac{b}{193}$} & \multirow{2}{*}{$\frac{c}{144}$} \\
\hline kontrollváltozó & -1 & & & \\
\hline kategória & 0 & 36 & 123 & 161 \\
\hline & 1 & 24 & 50 & 89 \\
\hline
\end{tabular}

\begin{tabular}{|c|c|c|c|c|}
\hline \multirow{2}{*}{\multicolumn{2}{|c|}{$\begin{array}{c}6 \mathrm{M} \text { jegy zések (\% kontroll } \\
\text { kategóriánként) }\end{array}$}} & \multicolumn{3}{|c|}{ klas zterek } \\
\hline & & $\mathrm{a}$ & $b$ & $\mathrm{c}$ \\
\hline \multirow{3}{*}{$\begin{array}{l}\text { kontrollváltozó } \\
\text { kategória }\end{array}$} & -1 & $11 \%$ & $51 \%$ & $38 \%$ \\
\hline & 0 & $11 \%$ & $38 \%$ & $50 \%$ \\
\hline & 1 & $15 \%$ & $31 \%$ & $55 \%$ \\
\hline
\end{tabular}


„G” bank

\begin{tabular}{|c|c|c|c|c|c|c|c|c|c|}
\hline \multirow{2}{*}{\multicolumn{2}{|c|}{ 3M jegyzések (db) }} & \multicolumn{3}{|c|}{ klas zterek } & \multirow{2}{*}{\multicolumn{2}{|c|}{$\begin{array}{c}3 \mathrm{M} \text { jegyzések (\% kontroll } \\
\text { kategóriánként) }\end{array}$}} & \multicolumn{3}{|c|}{ klas zterek } \\
\hline & & \multirow{2}{*}{$\frac{a}{99}$} & \multirow{2}{*}{$\frac{b}{40}$} & \multirow{2}{*}{$\frac{c}{98}$} & & & \multirow{2}{*}{$\frac{\mathrm{a}}{42 \%}$} & \multirow{2}{*}{$\frac{\mathrm{b}}{17 \%}$} & \multirow{2}{*}{$\frac{\mathrm{c}}{41 \%}$} \\
\hline kontrollváltozó & -1 & & & & \multirow{3}{*}{$\begin{array}{l}\text { kontrollváltozó } \\
\text { kategória }\end{array}$} & -1 & & & \\
\hline kategória & 0 & 144 & 71 & 273 & & 0 & $30 \%$ & $15 \%$ & $56 \%$ \\
\hline & 1 & 43 & 24 & 69 & & 1 & $32 \%$ & $18 \%$ & $51 \%$ \\
\hline
\end{tabular}

\begin{tabular}{|c|c|c|c|c|}
\hline \multirow{2}{*}{\multicolumn{2}{|c|}{$6 \mathrm{M}$ jegyzések (db) }} & \multicolumn{3}{|c|}{ klas zterek } \\
\hline & & \multirow{2}{*}{$\frac{\mathrm{a}}{46}$} & \multirow{2}{*}{$\frac{\mathrm{b}}{120}$} & \multirow{2}{*}{$\frac{\mathrm{c}}{125}$} \\
\hline kontrollváltozó & -1 & & & \\
\hline kategória & 0 & 69 & 111 & 208 \\
\hline & 1 & 27 & 57 & 98 \\
\hline
\end{tabular}

\begin{tabular}{|c|c|c|c|c|}
\hline \multirow{2}{*}{\multicolumn{2}{|c|}{$\begin{array}{c}\text { 6M jegyzések (\% kontroll } \\
\text { kategóriánként) }\end{array}$}} & \multicolumn{3}{|c|}{ klaszterek } \\
\hline & & $\mathrm{a}$ & $b$ & $\mathrm{c}$ \\
\hline \multirow{3}{*}{$\begin{array}{l}\text { kontrollváltozó } \\
\text { kategória }\end{array}$} & -1 & $16 \%$ & $41 \%$ & $43 \%$ \\
\hline & 0 & $18 \%$ & $29 \%$ & $54 \%$ \\
\hline & 1 & $15 \%$ & $31 \%$ & $54 \%$ \\
\hline
\end{tabular}

„H” bank

\begin{tabular}{|c|c|c|c|c|}
\hline \multirow{2}{*}{\multicolumn{2}{|c|}{ 3M jegyzések (db) }} & \multicolumn{3}{|c|}{ klas zterek } \\
\hline & & \multirow{2}{*}{$\frac{a}{64}$} & \multirow{2}{*}{$\frac{b}{42}$} & \multirow{2}{*}{$\frac{c}{61}$} \\
\hline kontrollváltozó & -1 & & & \\
\hline kategória & 0 & 327 & 119 & 220 \\
\hline & 1 & 11 & 1 & 16 \\
\hline
\end{tabular}

\begin{tabular}{|l|c|c|c|c|}
\hline \multirow{2}{*}{$\begin{array}{c}3 \text { M jegyzések (\% kontroll } \\
\text { kategóriánként) }\end{array}$} & \multicolumn{3}{|c|}{ klaszterek } \\
\cline { 2 - 5 } $\begin{array}{l}\text { kontrollváltozó } \\
\text { kategória }\end{array}$ & -1 & $38 \%$ & $25 \%$ & $37 \%$ \\
& 0 & $49 \%$ & $18 \%$ & $33 \%$ \\
& 1 & $39 \%$ & $4 \%$ & $57 \%$ \\
\hline
\end{tabular}

\begin{tabular}{|l|r|c|c|c|}
\hline \multicolumn{2}{|c|}{$6 \mathrm{M}$ jegyzések (db) } & \multicolumn{3}{|c|}{ klaszterek } \\
\cline { 2 - 5 } & $\mathrm{a}$ & $\mathrm{b}$ & $\mathrm{c}$ \\
\hline kontrollváltozó & -1 & 92 & 66 & 37 \\
kategória & 0 & 173 & 299 & 106 \\
& 1 & 12 & 63 & 13 \\
\hline
\end{tabular}

\begin{tabular}{|l|c|c|c|c|}
\hline \multirow{2}{*}{$\begin{array}{c}\text { 6M jegyzések (\% kontroll } \\
\text { kategóriánként) }\end{array}$} & \multicolumn{3}{|c|}{ klaszterek } \\
\cline { 2 - 5 } kontrollváltozó & -1 & $47 \%$ & $34 \%$ & $19 \%$ \\
kategória & 0 & $30 \%$ & $52 \%$ & $18 \%$ \\
& 1 & $14 \%$ & $72 \%$ & $15 \%$ \\
\hline
\end{tabular}

„I' bank

\begin{tabular}{|c|c|c|c|c|}
\hline \multirow{2}{*}{\multicolumn{2}{|c|}{ 3M jegyzések (db) }} & \multicolumn{3}{|c|}{ klas zterek } \\
\hline & & \multirow{2}{*}{$\frac{\mathrm{a}}{0}$} & \multirow{2}{*}{$\begin{array}{l}\mathrm{b} \\
7\end{array}$} & \multirow{2}{*}{$\frac{\mathrm{c}}{21}$} \\
\hline kontrollváltozó & -1 & & & \\
\hline kategória & 0 & 138 & 114 & 98 \\
\hline & 1 & 283 & 29 & 171 \\
\hline
\end{tabular}

\begin{tabular}{|c|c|c|c|c|}
\hline \multirow{2}{*}{\multicolumn{2}{|c|}{$\begin{array}{c}3 \mathrm{M} \text { jegyzések (\% kontroll } \\
\text { kategóriánként) }\end{array}$}} & \multicolumn{3}{|c|}{ klas zterek } \\
\hline & & a & $b$ & $\mathrm{c}$ \\
\hline \multirow{3}{*}{$\begin{array}{l}\text { kontrollváltozó } \\
\text { kategória }\end{array}$} & -1 & $0 \%$ & $25 \%$ & $75 \%$ \\
\hline & 0 & $39 \%$ & $33 \%$ & $28 \%$ \\
\hline & 1 & $59 \%$ & $6 \%$ & $35 \%$ \\
\hline
\end{tabular}

\begin{tabular}{|l|c|c|c|c|}
\hline \multirow{2}{*}{$6 \mathrm{M}$ jegyzések $(\mathrm{db})$} & \multicolumn{3}{|c|}{ klaszterek } \\
\cline { 2 - 5 } & $\mathrm{a}$ & $\mathrm{b}$ & $\mathrm{c}$ \\
\hline kontrollváltozó & -1 & 4 & 32 & 0 \\
kategória & 0 & 89 & 105 & 83 \\
& 1 & 216 & 157 & 175 \\
\hline
\end{tabular}

\begin{tabular}{|l|c|ccc|}
\hline \multicolumn{2}{|c|}{$\begin{array}{c}\text { 6M jegyzések (\% kontroll } \\
\text { kategóriánként) }\end{array}$} & \multicolumn{3}{|c|}{ klaszterek } \\
\cline { 2 - 5 } & $\mathrm{a}$ & $\mathrm{b}$ & $\mathrm{c}$ \\
\hline kontrollváltozó & -1 & $11 \%$ & $89 \%$ & $0 \%$ \\
kategória & 0 & $32 \%$ & $38 \%$ & $30 \%$ \\
& 1 & $39 \%$ & $29 \%$ & $32 \%$ \\
\hline
\end{tabular}


„J” bank

\begin{tabular}{|c|c|c|c|c|c|c|c|c|c|}
\hline \multirow{2}{*}{\multicolumn{2}{|c|}{ 3M jegyzések (db) }} & \multicolumn{3}{|c|}{ klas zterek } & \multirow{2}{*}{\multicolumn{2}{|c|}{$\begin{array}{c}\text { 3M jegyzések (\% kontroll } \\
\text { kategóriánként) }\end{array}$}} & \multicolumn{3}{|c|}{ klaszterek } \\
\hline & & \multirow{2}{*}{$\frac{a}{69}$} & \multirow{2}{*}{$\frac{\mathrm{b}}{38}$} & \multirow{2}{*}{$\frac{c}{56}$} & & & \multirow{2}{*}{$\frac{\mathrm{a}}{42 \%}$} & \multirow{2}{*}{$\frac{b}{23 \%}$} & \multirow{2}{*}{$\frac{\mathrm{c}}{34 \%}$} \\
\hline kontrollváltozó & -1 & & & & \multirow{3}{*}{$\begin{array}{l}\text { kontrollváltozó } \\
\text { kategória }\end{array}$} & -1 & & & \\
\hline kategória & 0 & 94 & 123 & 221 & & 0 & $21 \%$ & $28 \%$ & $50 \%$ \\
\hline & 1 & 67 & 72 & 121 & & 1 & $26 \%$ & $28 \%$ & $47 \%$ \\
\hline
\end{tabular}

\begin{tabular}{|c|c|c|c|c|c|c|c|c|c|}
\hline \multirow{2}{*}{\multicolumn{2}{|c|}{$6 \mathrm{M}$ jegyzések $(\mathrm{db})$}} & \multicolumn{3}{|c|}{ klas zterek } & \multirow{2}{*}{\multicolumn{2}{|c|}{$\begin{array}{c}\text { 6M jegyzések (\% kontroll } \\
\text { kategóriánként) }\end{array}$}} & \multicolumn{3}{|c|}{ klaszterek } \\
\hline & & \multirow{2}{*}{$\frac{\mathrm{a}}{125}$} & \multirow{2}{*}{$\frac{b}{26}$} & \multirow{2}{*}{$\frac{c}{102}$} & & & \multirow{2}{*}{$\frac{\mathrm{a}}{49 \%}$} & \multirow{2}{*}{$\frac{b}{10 \%}$} & \multirow{2}{*}{$\frac{\mathrm{c}}{40 \%}$} \\
\hline kontrollváltozó & -1 & & & & \multirow{3}{*}{$\begin{array}{l}\text { kontrollváltozó } \\
\text { kategória }\end{array}$} & -1 & & & \\
\hline kategória & 0 & 221 & 32 & 136 & & 0 & $57 \%$ & $8 \%$ & $35 \%$ \\
\hline & 1 & 99 & 33 & 87 & & 1 & $45 \%$ & $15 \%$ & $40 \%$ \\
\hline
\end{tabular}

„K” bank

\begin{tabular}{|c|c|c|c|c|}
\hline \multirow{2}{*}{\multicolumn{2}{|c|}{ 3M jegyzések (db) }} & \multicolumn{3}{|c|}{ klas zterek } \\
\hline & & $\mathrm{a}$ & $\mathrm{b}$ & $\mathrm{c}$ \\
\hline \multirow{3}{*}{$\begin{array}{l}\text { kontrollváltozó } \\
\text { kategória }\end{array}$} & -1 & 4 & 217 & 0 \\
\hline & 0 & 2 & 589 & 5 \\
\hline & 1 & 0 & 44 & 0 \\
\hline
\end{tabular}

\begin{tabular}{|c|c|c|c|c|}
\hline \multirow{2}{*}{\multicolumn{2}{|c|}{$\begin{array}{c}\text { 3M jegyzések (\% kontroll } \\
\text { kategóriánként) }\end{array}$}} & \multicolumn{3}{|c|}{ klaszterek } \\
\hline & & $\mathrm{a}$ & $\mathrm{b}$ & $\mathrm{c}$ \\
\hline \multirow{3}{*}{$\begin{array}{l}\text { kontrollváltozó } \\
\text { kategória }\end{array}$} & -1 & $2 \%$ & $98 \%$ & $0 \%$ \\
\hline & 0 & $0 \%$ & $99 \%$ & $1 \%$ \\
\hline & 1 & $0 \%$ & $100 \%$ & $0 \%$ \\
\hline
\end{tabular}

\begin{tabular}{|c|c|c|c|c|}
\hline \multirow{2}{*}{\multicolumn{2}{|c|}{$6 \mathrm{M}$ jegyzések (db) }} & \multicolumn{3}{|c|}{ klas zterek } \\
\hline & & $\mathrm{a}$ & $b$ & $\mathrm{c}$ \\
\hline \multirow{3}{*}{$\begin{array}{l}\text { kontrollváltozó } \\
\text { kategória }\end{array}$} & -1 & 7 & 133 & 131 \\
\hline & 0 & 0 & 219 & 294 \\
\hline & 1 & 0 & 48 & 29 \\
\hline
\end{tabular}

\begin{tabular}{|l|c|ccc|}
\hline \multirow{2}{*}{$\begin{array}{c}\text { 6M jegyzések (\% kontroll } \\
\text { kategóriánként) }\end{array}$} & \multicolumn{3}{|c|}{ klaszterek } \\
\cline { 2 - 5 } kontrollválttozó & -1 & $3 \%$ & $49 \%$ & $48 \%$ \\
kategória & 0 & $0 \%$ & $43 \%$ & $57 \%$ \\
& 1 & $0 \%$ & $62 \%$ & $38 \%$ \\
\hline
\end{tabular}

„L” bank

\begin{tabular}{|c|c|c|c|c|}
\hline \multirow{2}{*}{\multicolumn{2}{|c|}{ 3M jegyzések (db) }} & \multicolumn{3}{|c|}{ klas zterek } \\
\hline & & \multirow{2}{*}{$\begin{array}{l}\mathrm{a} \\
0\end{array}$} & \multirow{2}{*}{$\frac{\mathrm{b}}{11}$} & \multirow{2}{*}{$\begin{array}{c}\mathrm{c} \\
57\end{array}$} \\
\hline kontrollváltozó & -1 & & & \\
\hline kategória & 0 & 0 & 246 & 387 \\
\hline & 1 & 5 & 117 & 38 \\
\hline
\end{tabular}

\begin{tabular}{|l|c|ccc|}
\hline \multirow{2}{*}{$\begin{array}{c}3 \mathrm{M} \text { jegyzések (\% kontroll } \\
\text { kategóriánként) }\end{array}$} & \multicolumn{3}{|c|}{ klas zterek } \\
\cline { 2 - 5 } kontrollváltozó & -1 & $0 \%$ & $16 \%$ & $84 \%$ \\
kategória & 0 & $0 \%$ & $39 \%$ & $61 \%$ \\
& 1 & $3 \%$ & $73 \%$ & $24 \%$ \\
\hline
\end{tabular}

\begin{tabular}{|c|c|c|c|c|}
\hline \multirow{2}{*}{\multicolumn{2}{|c|}{$6 \mathrm{M}$ jegyzések (db) }} & \multicolumn{3}{|c|}{ klas zterek } \\
\hline & & \multirow{2}{*}{$\frac{\mathrm{a}}{20}$} & \multirow{2}{*}{$\frac{b}{4}$} & \multirow{2}{*}{$\frac{\mathrm{c}}{59}$} \\
\hline kontrollváltozó & -1 & & & \\
\hline kategória & 0 & 190 & 26 & 302 \\
\hline & 1 & 132 & 25 & 103 \\
\hline
\end{tabular}

\begin{tabular}{|c|c|c|c|c|}
\hline \multirow{2}{*}{\multicolumn{2}{|c|}{$\begin{array}{c}6 \mathrm{M} \text { jegyzések (\% kontroll } \\
\text { kategóriánként) }\end{array}$}} & \multicolumn{3}{|c|}{ klas zterek } \\
\hline & & \multirow{2}{*}{$\frac{\mathrm{a}}{24 \%}$} & \multirow{2}{*}{$\frac{\mathrm{b}}{5 \%}$} & \multirow{2}{*}{$\frac{\mathrm{c}}{71 \%}$} \\
\hline \multirow{3}{*}{$\begin{array}{l}\text { kontrollváltozó } \\
\text { kategória }\end{array}$} & -1 & & & \\
\hline & 0 & $37 \%$ & $5 \%$ & $58 \%$ \\
\hline & 1 & $51 \%$ & $10 \%$ & $40 \%$ \\
\hline
\end{tabular}


„M” bank

\begin{tabular}{|c|c|c|c|c|c|c|c|c|c|}
\hline \multirow{2}{*}{\multicolumn{2}{|c|}{$6 \mathrm{M}$ jegyzések $(\mathrm{db})$}} & \multicolumn{3}{|c|}{ klas zterek } & \multirow{2}{*}{\multicolumn{2}{|c|}{$\begin{array}{c}6 \mathrm{M} \text { jegyzések (\% kontroll } \\
\text { kategóriánként) }\end{array}$}} & \multicolumn{3}{|c|}{ klas zterek } \\
\hline & & \multirow{2}{*}{$\frac{\mathrm{a}}{10}$} & \multirow{2}{*}{$\frac{b}{66}$} & \multirow{2}{*}{$\begin{array}{c}c \\
55\end{array}$} & & & \multirow{2}{*}{$\frac{\mathrm{a}}{8 \%}$} & \multirow{2}{*}{$\frac{\mathrm{b}}{50 \%}$} & \multirow{2}{*}{$\frac{\mathrm{c}}{42 \%}$} \\
\hline kontrollváltozó & -1 & & & & \multirow{3}{*}{$\begin{array}{l}\text { kontrollváltozó } \\
\text { kategória }\end{array}$} & -1 & & & \\
\hline kategória & 0 & 27 & 193 & 296 & & 0 & $5 \%$ & $37 \%$ & $57 \%$ \\
\hline & 1 & 21 & 115 & 78 & & 1 & $10 \%$ & $54 \%$ & $36 \%$ \\
\hline
\end{tabular}

„N" bank

\begin{tabular}{|c|c|c|c|c|}
\hline \multirow{2}{*}{\multicolumn{2}{|c|}{ 6M jegyzések (db) }} & \multicolumn{3}{|c|}{ klaszterek } \\
\hline & & \multirow{2}{*}{$\frac{\mathrm{a}}{35}$} & \multirow{2}{*}{$\frac{\mathrm{b}}{84}$} & \multirow{2}{*}{$\frac{c}{0}$} \\
\hline kontrollváltozó & -1 & & & \\
\hline kategoria & 0 & 282 & 188 & 4 \\
\hline & 1 & 162 & 105 & 1 \\
\hline
\end{tabular}

\begin{tabular}{|l|c|c|c|c|}
\hline \multirow{2}{*}{$\begin{array}{c}\text { 6M jegyzések (\% kontroll } \\
\text { kategóriánként) }\end{array}$} & \multicolumn{3}{|c|}{ klaszterek } \\
\cline { 2 - 5 } & -1 & $\mathrm{a}$ & $\mathrm{b}$ & $\mathrm{c}$ \\
\hline $\begin{array}{l}\text { kontrollváltozó } \\
\text { kategória }\end{array}$ & 0 & $59 \%$ & $71 \%$ & $0 \%$ \\
& 1 & $60 \%$ & $39 \%$ & $1 \%$ \\
\hline
\end{tabular}


8.6. Melléklet: Az intézmények jegyzésének eltérése a napi BUBOR értékhez képest 2006.január - 2012. június (3 illetve 6 hónapos tenor)

forrás: $M N B$

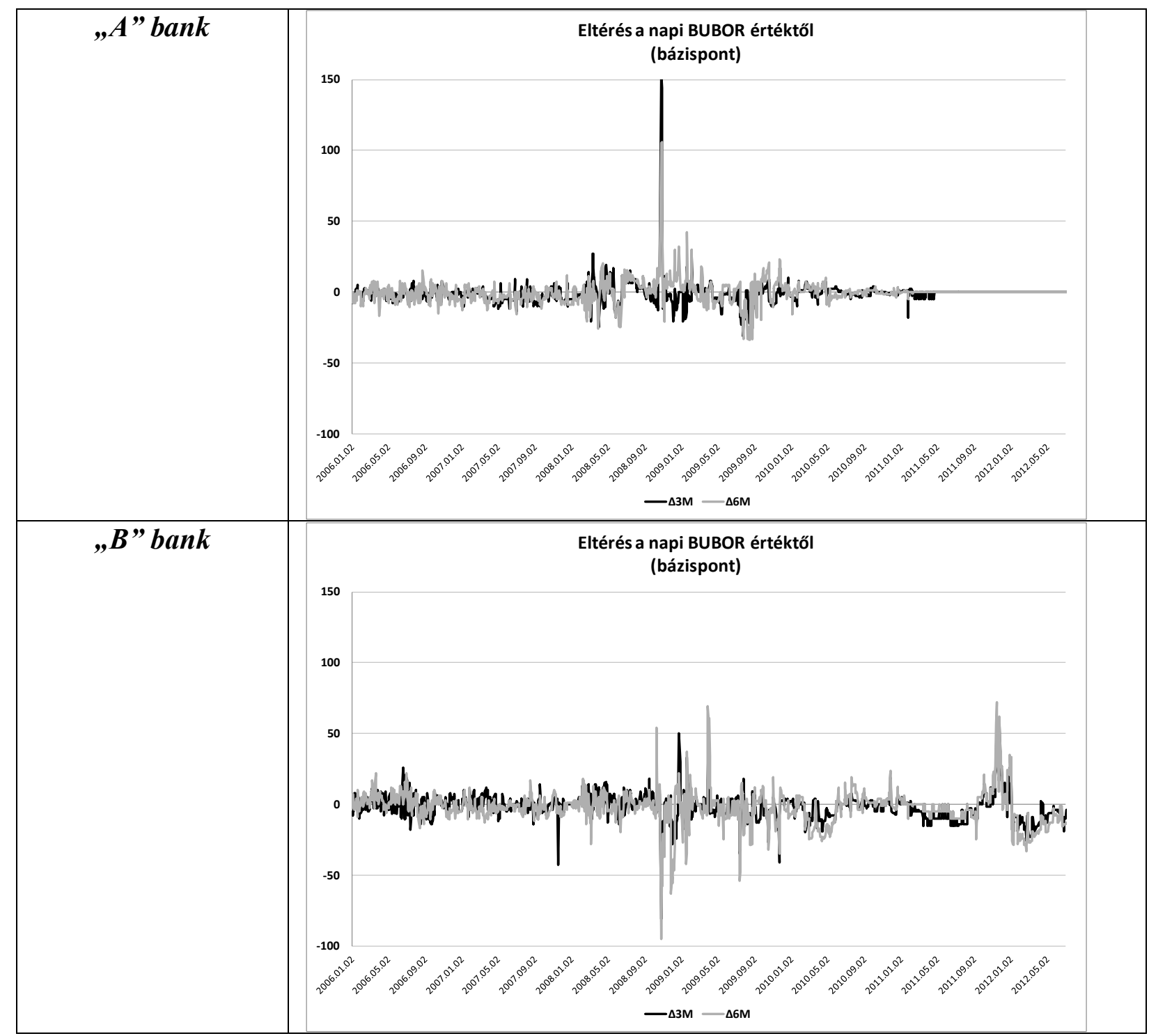




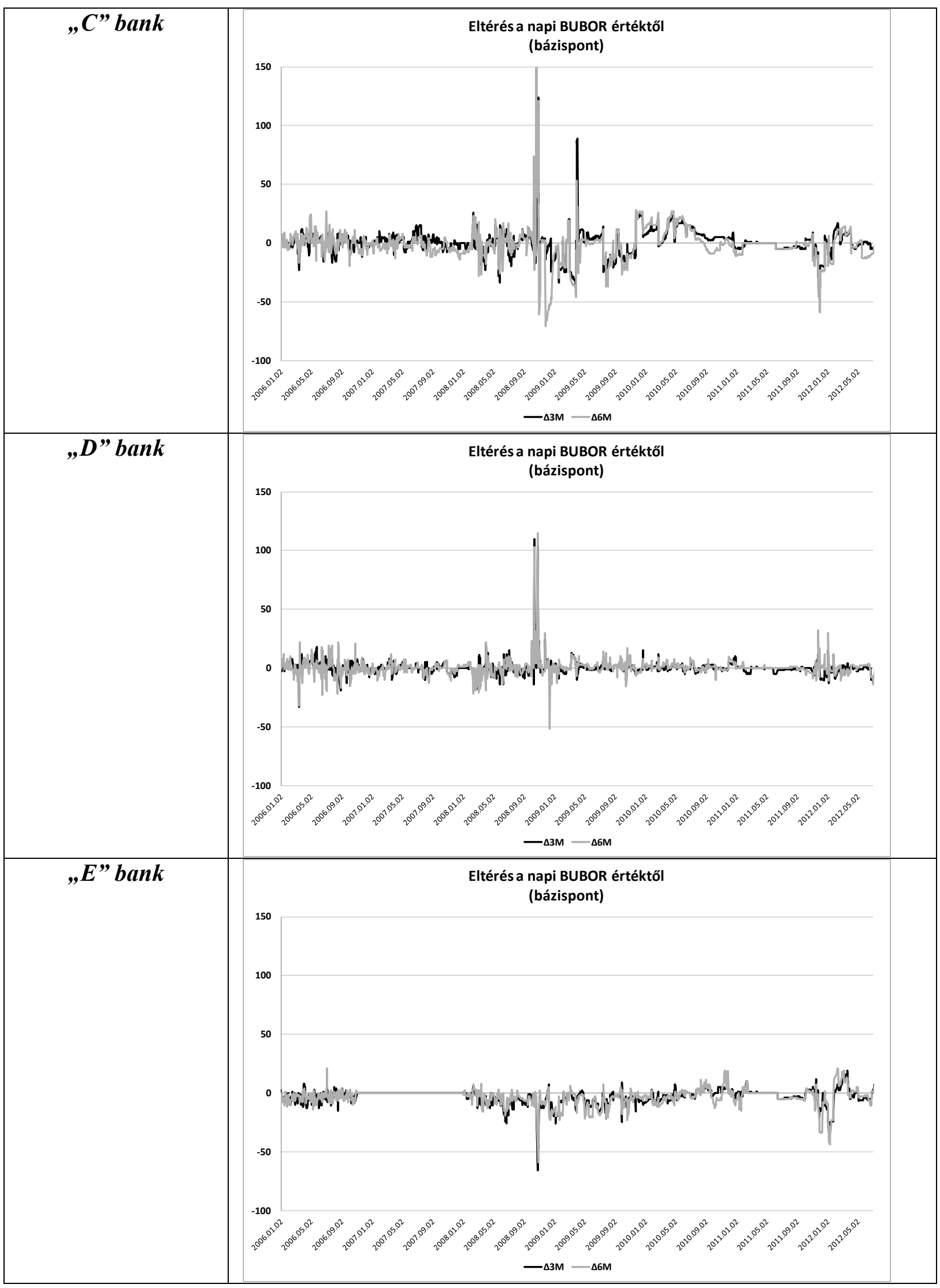




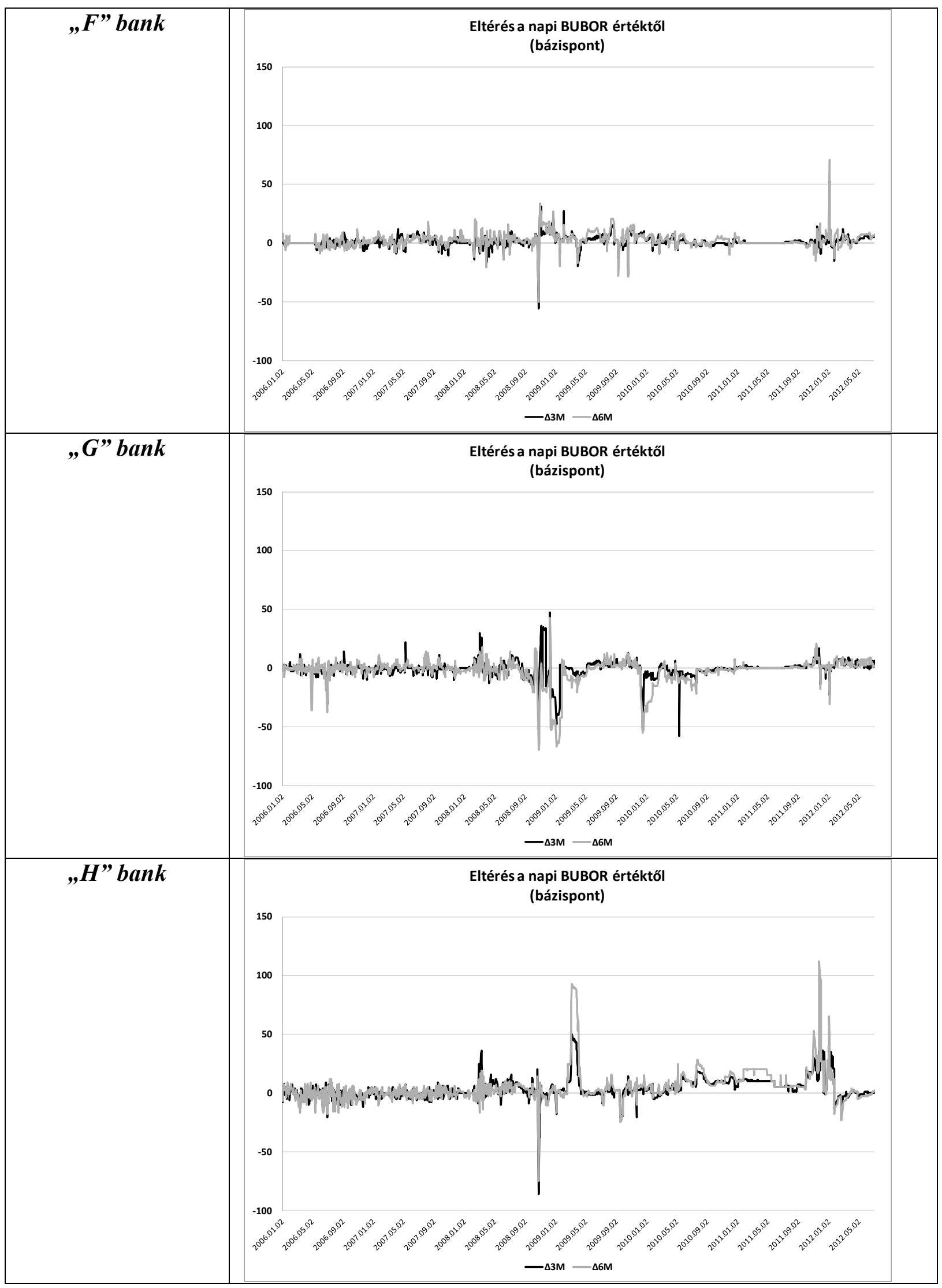




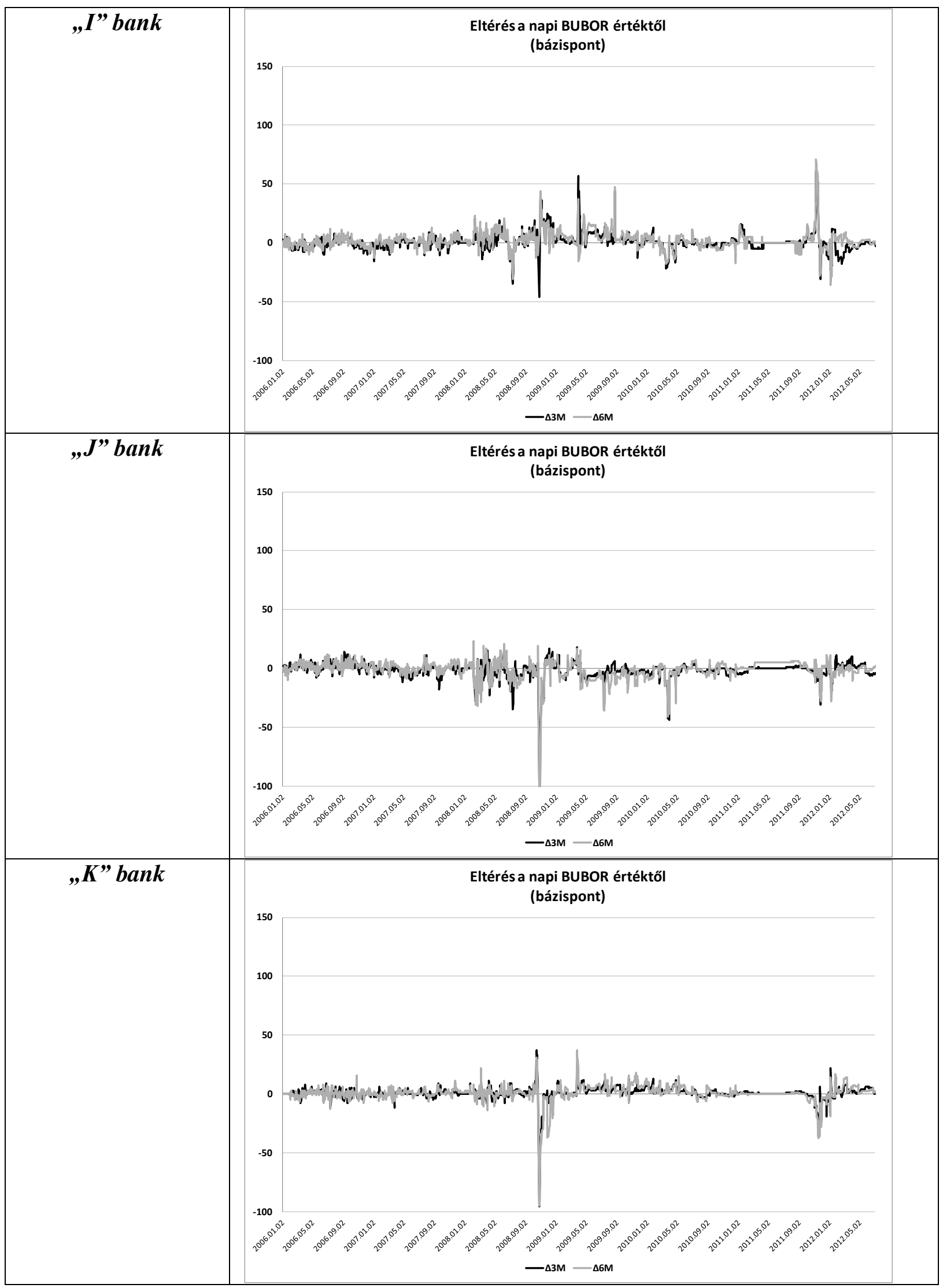




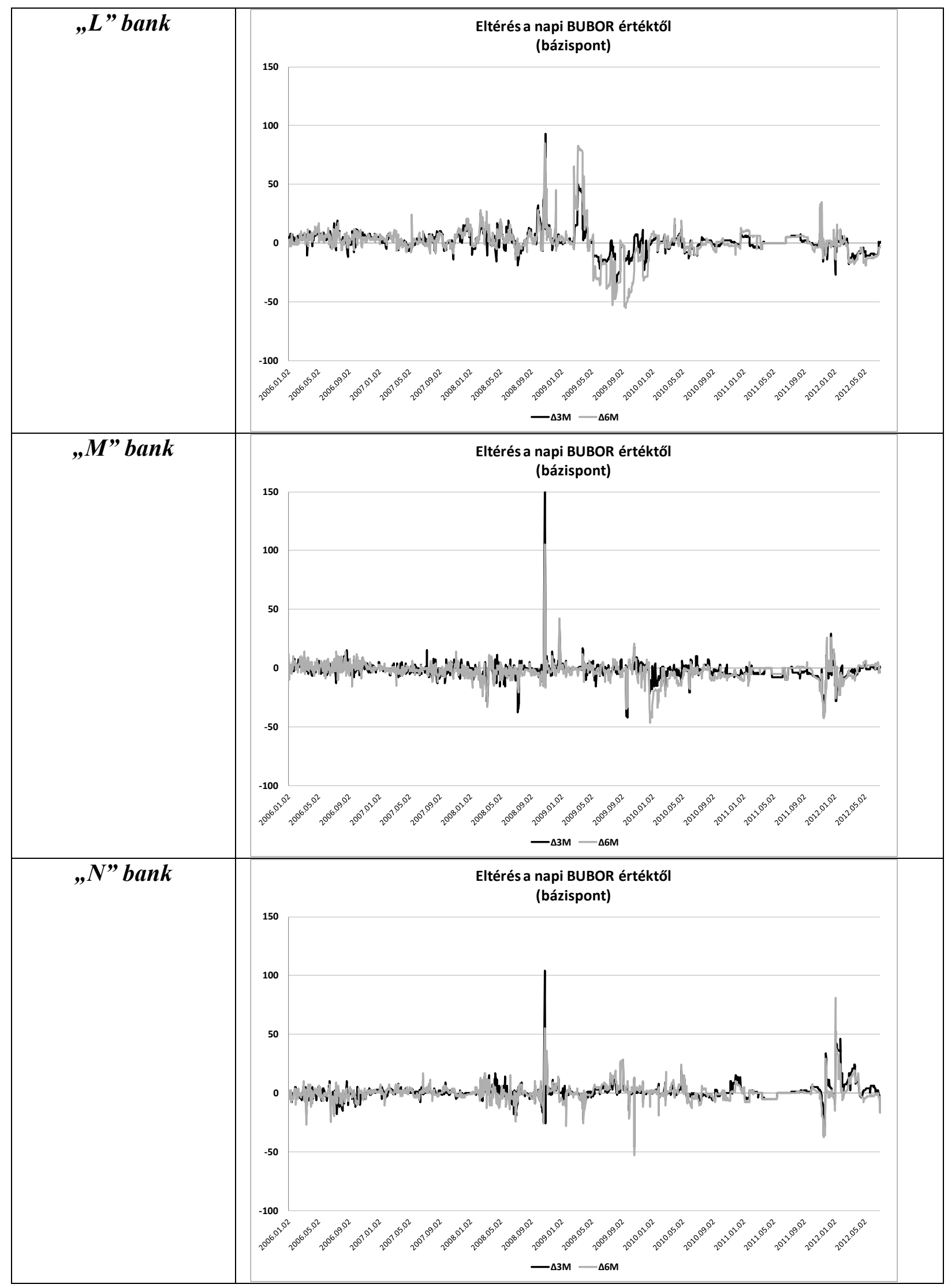




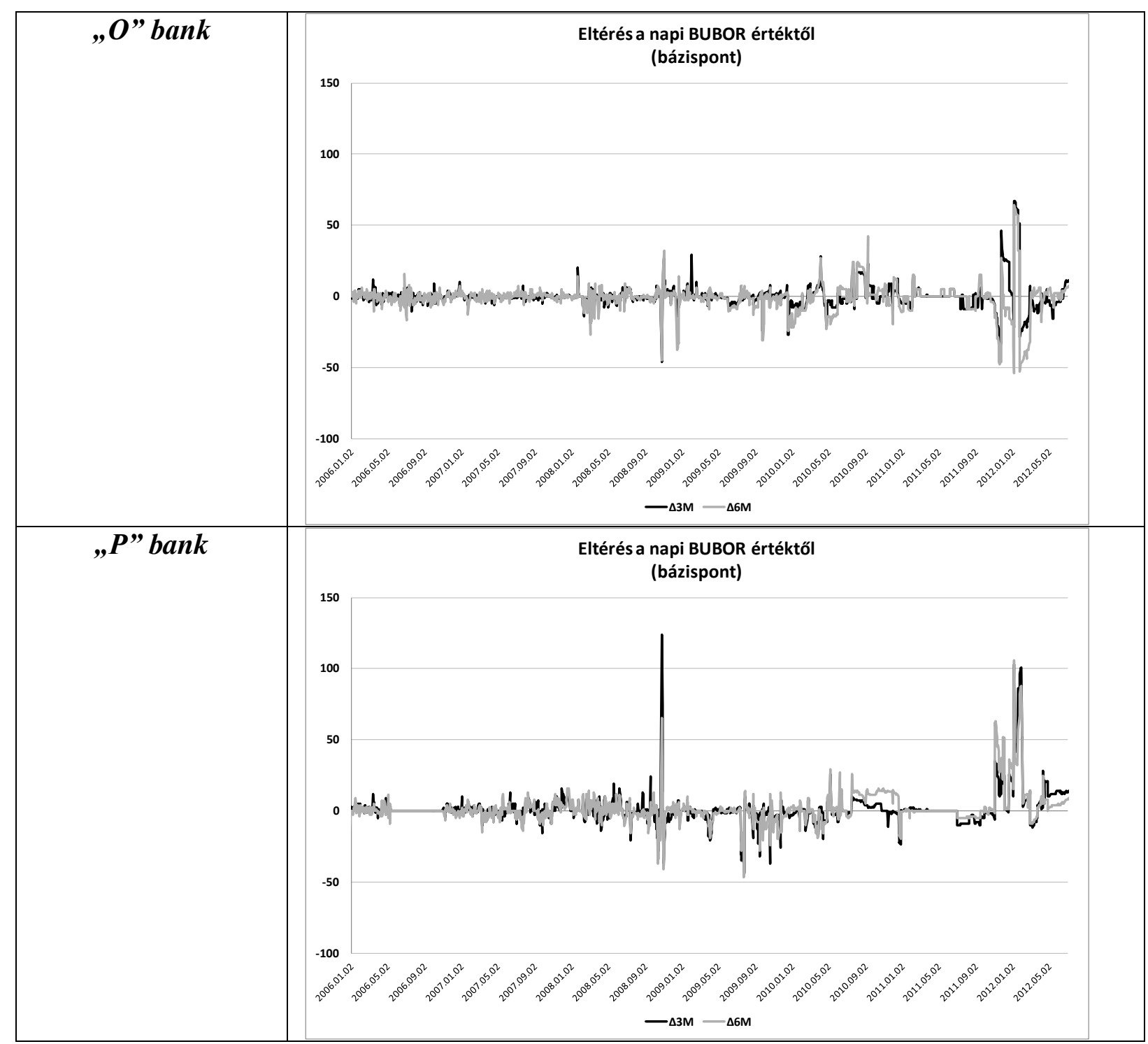




\subsection{Melléklet: Fogalmak}

aktív kamatjegyzö

BUBOR

cross-currency interest rate swap (CIRS)

EURIBOR

foreign exchange (FX) swap

forward rate aggreement (FRA)

HUFONIA

interest rate swap (IRS)
A referencia-érték jegyzésében adott időpontban résztvevő intézmény, melynek kijelölt kereskedője a referencia-érték szabályzatában megadott időpontban és módon lejelenti az intézmény által a definíciónak megfelelő értéket.

Budapesti bankközi forint hitelkamatláb. (Budapest Interbank Offered Rate)

Olyan megállapodás, amelynek keretében a két szerződő fél eltérő devizában lévő kamatfizetési kötelezettségeit meghatározott időszakra vonatkozóan elcseréli. Például egy HUF fix kamatfizetési kötelezettség elcserélése EUR változó kamatfizetési kötelezettségre, vagy két változó kamatozású, de eltérő bázis alapján számított (például BUBOR és EURIBOR) kötelezettség cseréje.

Az európai bankok részvételével kialakított irányadó bankközi kamatláb. Először 1999. január 1-én az euró bevezetésével együtt került jegyzésre. (Euro Interbank Offered Rate)

Olyan szerződés, melynek keretében két szerződő fél adott árfolyam mellett különböző devizában egy meghatározott összeget cserél el és kötelezettséget vállal, hogy egy adott időpontban a szerződésben meghatározott árfolyam mellett visszacseréli az összeget.

Kétoldalú szerződés, amelyben egy jövőbeli periódusra, meghatározott összeg után fizetendő fix kamatban állapodnak meg. HUF FRA esetén a tökeösszegeket nem cserélik, csak a kamatmegállapítás időpontjaiban érvényes piaci kamat (BUBOR) és az FRA keretében megállapított kamat különbségének tőkére vetített összegét.

A HUFONIA (Hungarian Forint Overnight Index Average) az az effektív overnight kamatláb, amely a bankközi piacon az összes bank, szakosított hitelintézet és EGT fióktelep által egymással kötött overnight forinthitel és forintbetét ügyletek forgalommal súlyozott átlagos kamatlába. Naponta az MNB számítja ki az intézmények kötelező adatszolgáltatása alapján.

Olyan megállapodás, amelynek keretében a két szerződő fél ugyanabban a devizában lévő kamatfizetési kötelezettségeit meghatározott időszakon keresztül elcseréli. Például egy fix kamatfizetési kötelezettség elcserélése változó kamatra, vagy két változó kamatozású, de eltérő bázis alapján számított (például HUF referencia-kamatláb és BUBOR) kötelezettség cseréje.

Londoni bankközi referencia-kamatláb, melynek jegyzése 10 
O/N kamat

referencia-kamatláb

trader

trimmelés

WIBOR devizában történik. (London Interbank Offered Rate)

Overnight - egynapos elszámolások alapjául szolgáló kamatláb.

Változó kamat számításának alapjául szolgáló, a nyilvánosság számára hozzáférhető mindenkori kamatláb, amelynek mértékére a hitelezőnek nincs közvetlen ráhatása.

A szerződéses összeg visszafizetéséig hátralévő időszak, futamidő.

Kereskedő. Pénzintézetek bankközi piacon kereskedést végző munkatársa.

Nyesés. Adott sokaságból bizonyos elemek elhagyása. Például nyesett átlag esetén egy megadott arány szerinti legmagasabb illetve legalacsonyabb értékek elhagyása az átlagszámításból.

Varsói bankközi referencia-kamatláb, melynek jegyzése 10 devizában történik. (Warsaw Interbank Offered Rate) 


\subsection{Hivatalos BUBOR szabályzat 2014. augusztus 1 .}

forrás: Magyar Forex Társaság [2014a]

\section{„BUBOR szabályzat}

2014. augusztus 01.

A Magyar Forex Társaság szabályzata a Budapest Bankközi Forint Hitelkamatláb fixing eljárásáról.

\section{Bevezető}

A Magyar Forex Társaság (MFT), a hazai hitelintézetekben dolgozó deviza és pénzpiaci kereskedők szakmai szervezete, alapvető feladatának tartja a hazai pénzügyi piacok szerveződésének és fejlődésének aktív szakmai elősegítését. A Budapesti Bankközi Forint Hitelkamatláb (továbbiakban BUBOR) 1996. augusztusi indulását (1 és 3 havi fixing), majd 1997. májusi bevezetését követően ( 6 havi fixing) rövid idő alatt a bankok forint hitelezéseinek elsődlegesen alkalmazott kamatbázisává vált a hazai piacon. A BUBOR, mint az egyetlen bankközi forint kamat fixing, jó alapot jelentett a határidős tőzsdei kamatfutures üzletekhez, továbbá mint referencia kamatláb elősegítheti a származtatott ügyletek (FRA, IRS, kamatopciók) piacának fejlődését is. Az MFT továbbra is egyik legfontosabb feladatának tekinti, hogy a BUBOR - amelyet a piac kezdeményezésére és a piac fejlődése érdekében hozott létre - a jövőben is betöltse feladatát és referencia rátaként szerepelhessen a változó kamatozású passzívák és aktívák árazásánál, valamint a tőzsdei és a tőzsdén kívüli származtatott kamatügyletek elszámolásánál. Az MFT figyelemmel kíséri a nemzetközi pénz- és tőkepiacok és a nemzetközi kamat fixing eljárások (pl. LIBOR, EURIBOR) fejlődését illetve a vonatkozó szabályozói háttér változásait, és szükség esetén időről időre gondoskodik a nemzetközi szokványoknak és "best practice" eljárásoknak a BUBOR fixing eljárásba történő esetleges átültetéséről. 


\section{A szabályzatban használt fogalmak értelmezése}

\subsection{Kamatjegyző bank}

Minden olyan bank, amely:

(a) elfogadta a BUBOR fixing lebonyolításának szabályzatát; és

(b) kész a BUBOR fixing eljárásban való részvételre.

\subsection{Aktív kamatjegyző bank}

Minden olyan kamatjegyző bank, amely az adott napon kamatot jegyez a BUBOR fixingben, az 5. pontban foglaltaknak megfelelően.

\subsection{Kamatjegyzés}

Azon az adott kamatjegyzést szolgáltató bank által meghatározott kamatlábat jelenti, amely kamatlábon a kamatjegyzést szolgáltató bank legjobb tudomása és megítélése szerint az adott magyar banki munkanapon, a Melléklet 2. pontjában foglalt időpontban, a Melléklet 3. pontjában megjelölt futamidők vonatkozásában és a 3.4. pontban foglaltak figyelembe vétele mellett valamely az 5.1 pont szerint meghatározott aktív kamatjegyző bank egy másik aktív kamatjegyző bank részére fedezetlen bankközi hitel (ún. unsecured interbank loan) nyújtására üzleti ajánlatot tenne.

\subsection{Hírügynökség}

A BUBOR fixing elsődleges publikálására jogosult hírügynökségek listáját a szabályzat melléklete tartalmazza.

\subsection{Figyelmen Kívül Hagyandó Kamatjegyzések}

Az adott magyar banki munkanapon és az adott futamidő vonatkozásában a Magyar Nemzeti Bankhoz (MNB) beérkezett kamatjegyzések tekintetében:

(a) a négy legmagasabb és négy legalacsonyabb kamatjegyzést jelenti, amennyiben a beérkezett kamatjegyzések száma eléri a 16-ot; 
(b) a három legmagasabb és három legalacsonyabb kamatjegyzést jelenti, amennyiben a beérkezett kamatjegyzések száma eléri vagy meghaladja a 12-őt de nem éri el a 16-ot;

(c) a két legmagasabb és két legalacsonyabb kamatjegyzést jelenti, amennyiben a beérkezett kamatjegyzések száma eléri vagy meghaladja a 7-et de nem éri el a 12-őt;

(d) a legmagasabb és a legalacsonyabb kamatjegyzést jelenti, amennyiben a beérkezett kamatjegyzések száma nem éri el a 7-et.

\section{A fixing eljárás}

3.1. A fixing számításba bekerülő kamatokat az aktív kamatjegyző bankok minden magyar banki munkanapon, a Melléklet 2. pontjában meghatározott időpontban, a rendelkezésükre álló módon - szükség esetén telefaxon - közlik a kamatok rögzítését és összegzését végző MNB-vel.

3.2. A kamatjegyzéseknek a Melléklet 3. pontjában meghatározott futamidőkre kell vonatkozniuk.

3.3. Az MNB a beérkezett kamatjegyzéseket összegzi, és a futamidőnként Figyelmen Kívül Hagyandó Kamatjegyzések elhagyásával kiszámítja az aznap rögzítendő BUBOR kamatlábakat. A számítás módja a futamidőnként megmaradt kamatjegyzéseknek a kerekítés szabályai szerint számított számtani középértékének a meghatározása, két tizedes jegyre kerekítve.

3.4. Az aktív kamatjegyző bankok által közölt, a fixing számításba bekerülő kamatok és a belőlük képzett BUBOR kamatok a fixinget követő második magyar banki munkanappal megkötésre kerülő üzletekre vonatkoznak, kivéve az overnight periódust, ahol az üzletkötés napja megegyezik a teljesítés napjával.

3.5. A kamatfixálás során használt dokumentumok tárolásáról és megőrzéséről az MFT Szakmai Bizottságának az MNB által delegált tagja gondoskodik.

\section{A BUBOR publikálása}

4.1. A BUBOR fixing megállapítását követően a BUBOR kamatokat, az aktív kamatjegyző bankok nevét és kamatjegyzéseiket az MNB haladéktalanul a hírügynökségek rendelkezésére 
bocsátja publikálás céljából. Ezen adatok elektronikus módon, historikusan (azaz adott esetben 2004. januárjáig visszamenőlegesen) történő közzétételéről a Melléklet 4. pontjában megjelölt hírügynökségek gondoskodnak.

4.2. Az MNB által a 4.1. pontban foglaltak szerint a hírügynökségek rendelkezésére bocsátott kamatok tekintendők a hivatalos BUBOR fixingnek.

\section{Az aktív kamatjegyző bankok körének megállapítása}

5.1. Az aktív kamatjegyző bankok listáját az MFT Szakmai Bizottsága az MNB közremúködésével állapítja meg és az aktív kamatjegyző bankok számát közzéteszi a Melléklet 1. pontjában. A lista alapjául 50\%-ban a tárgyidőszakot megelőző naptári negyedév futamidővel súlyozott teljes HUF bankközi betét/hitel és devizacsere ügyletek forgalmi ranglista, valamint 50\%-ban a tárgyidőszakot megelőző naptári negyedév végén jelentett mérleg-főösszeg alapján felállított lista szolgál. A devizacsere ügyletek esetében az induló értéknapra kötött HUF összeg kerül figyelembevételre. Az így képzett listán szereplő bankok közül, a listán elért sorrendnek megfelelően az MFT Szakmai Bizottsága által az MNB közremúködésével meghatározott és a Melléklet 1. pontjában időről időre közzétett számú, de legfeljebb 16 bank vesz részt a BUBOR fixing eljárásban.

5.2. A forgalmi ranglista alapját képező adatok nem publikusak, azokat az MNB bizalmasan kezeli és legalább 5 évre visszamenőleg megőrzi.

5.3. Amennyiben a jegyzési periódus során az aktív kamatjegyző bankok bármelyike lemond jegyzési jogáról, úgy a ranglista sorrendben következő kamatjegyző bankja válik aktív kamatjegyzővé.

5.4. Az aktív kamatjegyző bankok listáját a naptári negyedévet követő hónap végén az MFT az MNB közremúködésével a piaci fejlemények tükrében felülvizsgálja, majd az 5.1. pont alapján kijelöli a következő 3 hónap aktív kamatjegyző bankjait.

5.5. Az MFT Szakmai Bizottságának javaslata alapján az MFT Vezetősége - előzetes, nyilvános (az MFT internetes honlapján közzétett) és írásos figyelmeztetést követően - jogosult bármely aktív kamatjegyző bank BUBOR jegyzési jogát felfüggeszteni, amennyiben ezen bank 
az adott jegyzési időszakban visszatérő módon a 2.3 pontban foglaltaktól eltérően jegyzi kamatait a BUBOR fixingbe.

\section{Egyebek}

6.1. A 6.2-es pontban foglaltak kivételével a szabályzatnak és mellékletének megváltoztatásáról az MFT Szakmai Bizottságának javaslata alapján a szavazásban részt vevő aktív kamatjegyző bankok egyszerű többséggel döntenek.

6.2 Az MFT Szakmai Bizottsága az MNB által adott előzetes álláspont ismeretében saját hatáskörében jogosult a Melléklet 1. és 4. pontjának módosítására.

\section{Melléklet}

1. Az aktív kamatjegyzők száma: 09

Kamatjegyző bankok:

1. Budapest

2. $\mathrm{CIB}$

3. Erste

4. $\mathrm{K} \& H$

5. MKB

6. OTP

7. Raiffeisen

8. Takarék

9. Unicredit

2. A jegyzéseknek az MNB-hez való eljuttatásának időpontja: 10:15h és 10.30h között

3. A jegyzett futamidők: overnight, 1 hét, 2 hét, 1, 2, 3, 6, 9 és 12 hónap

4. A BUBOR fixinget (ideértve a jegyző bankok által leadott egyedi jegyzések historikus módon történő publikálását is):

(a) elsődlegesen publikáló hírügynökségek: THOMSON REUTERS, BLOOMBERG;

(b) historikusan publikáló hírügynökségek: THOMSON REUTERS, BLOOMBERG” 


\subsection{Melléklet: Játékelméleti fejezet állításainak bizonyítása}

\section{1. Állítás}

Amennyiben eltekintünk a kooperáció lehetőségétöl és minden szereplö a döntésénél a saját piaci pozícióiból indulna ki, minden szereplö manipulálna, vagyis senki sem mondana igazat.

\section{Bizonyítás}

A tanulmányban bemutatott modell analógiáját felhasználva, tekintsük $\mathrm{F}$ intézményt. Tegyük fel, hogy F-nek nagyobb profitot eredményez - a saját kamatpozícióit figyelembe véve - ha magasabb a rögzített referencia-kamat. Továbbá tegyük fel, hogy $\mathrm{F}$ két értékből választhat, $\mathrm{V}$ valós illetve $\mathrm{M}=\mathrm{V}+\beta$, manipulált, ahol $\beta>0$. A jegyzést $\mathrm{n} \geq 1$ számú intézmény végzi (a jegyzések: $r_{1} \leq \ldots \leq r_{n}$ ), a referencia-kamat értékének meghatározása során a jegyzések alsó illetve felső 25\%-át lenyesik, a referencia-kamat aktuális értéke a többi jegyzés egyszerü számtani átlagaként adódik. Jelölje n/4 egész részét b. Ekkor a napi referencia-kamat (R)

$$
R=\frac{\sum_{i=b+1}^{n-b} r_{i}}{n-2 b}
$$

Ekkor V-re az alábbiak teljesülhetnek:
a) $V \in\left\{r_{1}, \ldots, r_{b}\right\}$
b) $V \in\left\{r_{b+1}, \ldots, r_{n-b}\right\}$
c) $V \in\left\{r_{n-b+1}, \ldots, r_{n}\right\}$

Legyen $\mathrm{F}$ intézmény $\mathrm{V}$ választása esetén $\mathrm{v}=\mathrm{r}_{\mathrm{b}+1}$ és $\mathrm{W}=\mathrm{r}_{\mathrm{n}-\mathrm{b}+1}$.

Amennyiben $\mathrm{F}$ intézmény $\mathrm{V}$ helyett $\mathrm{M}=\mathrm{V}+\beta$ értéket jegyez

a) ha $V \in\left\{r_{1}, \ldots, r_{b}\right\}$, akkor $M \in\left\{r_{1}, \ldots, r_{b}\right\}$ vagy $M \in\left\{r_{b+1}, \ldots, r_{n-b}\right\}$ vagy $M \in$ $\left\{r_{n-b+1}, \ldots, r_{n}\right\}$, és

○ $M \in\left\{r_{1}, \ldots, r_{b}\right\} \mathrm{M}$ jegyzést $\mathrm{V}$-hez hasonlóan lenyesik, így R értéke változatlan.

○ ha $M \in\left\{r_{b+1}, \ldots, r_{n-b}\right\}$ akkor $\mathrm{v}=\mathrm{V}+\gamma$, ahol $\gamma \geq 0$ és $\mathrm{M}=\mathrm{v}+\beta-\gamma$, ahol $\beta-\gamma$ $\geq 0$, ekkor az M választása melletti referencia-kamatláb

$$
\hat{R}=\frac{\sum_{i=b+1}^{n-b} r_{i}+\beta-\gamma}{n-2 b}=R+\frac{\beta-\gamma}{n-2 b}
$$

mivel $\beta-\gamma \geq 0$ nyilvánvaló, hogy $M$ választása nem eredményez rosszabb kimenetet $\mathrm{F}$ számára.

○ ha $M \in\left\{r_{n-b+1}, \ldots, r_{n}\right\}$ akkor az $\mathrm{V}$ jegyzés esetén adódó más intézmény által adott $\mathrm{w}=\mathrm{r}_{\mathrm{n}-\mathrm{b}}$ jegyzést nem nyesik le. Mivel $\mathrm{V}$ jegyzése esetén $\mathrm{w}$-t felülről lenyesik, $\mathrm{w}=\mathrm{V}+\delta$, ahol $\delta \geq 0$ és $\mathrm{M}=\mathrm{v}+\beta-\delta$, ahol $\beta-\delta \geq 0$, ekkor az M választása melletti referencia-kamatláb 


$$
\hat{R}=\frac{\sum_{i=b+1}^{n-b} r_{i}+\beta-\delta}{n-2 b}=R+\frac{\beta-\delta}{n-2 b}
$$

mivel $\beta-\delta \geq 0$ nyilvánvaló, hogy $M$ választása nem rosszabb $F$ számára $V$ választásánál.

b) ha $V \in\left\{r_{b+1}, \ldots, r_{n-b}\right\}$, akkor $M \in\left\{r_{b+1}, \ldots, r_{n-b}\right\}$ vagy $M \in\left\{r_{n-b+1}, \ldots, r_{n}\right\}$,

○ ha $M \in\left\{r_{b+1}, \ldots, r_{n-b}\right\}$ akkor

$$
\hat{R}=\frac{\sum_{i=b+1}^{n-b} r_{i}+\beta}{n-2 b}=R+\frac{\beta}{n-2 b}
$$

mivel $\beta>0$ nyilvánvaló, hogy $\hat{R}>R$, vagyis $\mathrm{F}$ intézmény jobban jár $\mathrm{M}$ jegyzésével.

○ ha $M \in\left\{r_{n-b+1}, \ldots, r_{n}\right\}$, mivel $\mathrm{V}$ jegyzése esetén $\mathrm{w}-\mathrm{t}$ lenyesik, $\mathrm{w}=\mathrm{V}+\delta$, ahol $\delta \geq 0$. M választásával azonban w benn marad az átlagolásban, így a rögzített referencia-érték

$$
\hat{R}=\frac{\sum_{i=b+1}^{n-b} r_{i}+\delta}{n-2 b}
$$

mivel $\delta \geq 0$, nyilvánvalóan $\hat{R} \geq R$.

c) ha $V \in\left\{r_{n-b+1}, \ldots, r_{n}\right\}$, akkor nyilvánvaló, hogy $M \in\left\{r_{n-b+1}, \ldots, r_{n}\right\}$, vagyis $\mathrm{M}$ jegyzést V-hez hasonlóan lenyesik, így R értéke változatlan.

Látható, hogy nincs olyan eset, melyben $\mathrm{M}$ választásával $\mathrm{F}$ rosszabbul járna, sőt van olyan mikor szigorúan jobb is a kimenet a számára. Ebböl következően bármit is jelent a többi kamatjegyző, megéri M-t választani. Mivel a többi szereplő esetén is levezethető a fenti gondolatmenet, a jegyzésnél minden szereplő számára kifizetődőbb a manipuláció választása.

\section{2. Állítás}

Amennyiben létezne $N=M+\varepsilon$ jegyzés, ahol $\varepsilon \geq 0$ és $N$ szintén benne van a $[V, U]$ intervallumban, akkor $N$ jegyzés választása gyengén dominálná $M$ választását, vagyis $F$ nem járna rosszabbul, ha $N$-t mond $M$ helyett. Ha feloldanánk a feltevést és $F$ ismerné az U-t, akkor a fentiekhez hasonlóan belátható, hogy U lenne az optimális választás.

\section{Bizonyítás}

Tegyük fel, hogy létezik ilyen $N=M+\varepsilon$ jegyzés, mely benne van $[V, U]$ intervallumban. Azt a korábbi feltevésekből tudjuk, hogy $\mathrm{F}$ számára a nagyobb referencia-kamatláb nagyobb kifizetést eredményez. Ekkor az első állítás bizonyításánál gyakorlatilag azt is beláttuk, hogy egy adott jegyzésnél nagyobb érték jegyzése nem eredményezhet rosszabb kimenetet $\mathrm{F}$ 
számára. Ha az ottani gondolatmenetbe $\mathrm{V}$ helyett M-et és M helyett N-t helyettesítünk, megkapjuk az állítás első felét.

Amennyiben $U$ ismert, akkor nyilvánvaló, hogy U a legnagyobb olyan érték, melyet megéri lebukás nélkül $\mathrm{F}$ intézménynek választania. Az első állítás gondolatmenete alapján $\mathrm{U}$ a $[\mathrm{V}, \mathrm{U}]$ intervallum bármely más eleménél nem rosszabb választás, viszont bármely más elem választása eredményezhet rosszabb kimenetet mint U választása, vagyis ha $\mathrm{U}$ ismert, akkor az optimális jegyzés U. 


\section{Publikációs jegyzék}

\subsection{Disszertáció tervezet témájában}

- Fliszár V. [2013]: A BUBOR-hoz köthető állományok és a BUBOR jegyzések részletes statisztikai elemzése, PSZÁF, 2013, tanulmány

- Fliszár V.: [2013]: In the shadow of LIBOR - the Attribution of BUBOR market, Annual, Annual Financial Market Liquidity Conference 2013, BCE, konferenciaelőadás

- Fliszár V. [2013]: A LIBOR árnyékában - a BUBOR piac, Tanszéki Szeminárium, BCE Operációkutatás és Aktuáriustudományok Tanszék, 2013, előadás

- Fliszár V. [2015]: A BUBOR-piac kiszáradásának jelei, avagy mi olvasható ki a 2006 és 2012 közötti BUBOR-jegyzésekből, Statisztikai Szemle, 2015/03, 243-259.

- Fliszár V. [2016]: Csökkenthető a referencia-kamatok manipulálásának valószínüsége? - lehetséges irányok egy egyszerüsített modell alapján a Barclays adatainak felhasználásával, Közgazdasági Szemle, befogadott - várható megjelenés 2016 első negyedév

\subsection{Disszertáció tervezetben felhasznált módszertanokkal kapcsolatos publikációk}

- Kovács E. - Fliszár V. - Szüle B. - Vékás P. [2011]: Pénzügyi adatok statisztikai elemzése (szerk.: Kovács Erzsébet), Tanszék Kft., Budapest, 2011, könyvfejezet

- Szüle B. - Kovács E. - Fliszár V. - Szepesváry L. [2015]: Többváltozós statisztika feladatgyüjtemény, könyvfejezet, nyomdai szerkesztés alatt 